MUSICAL

ART and EDUCATION

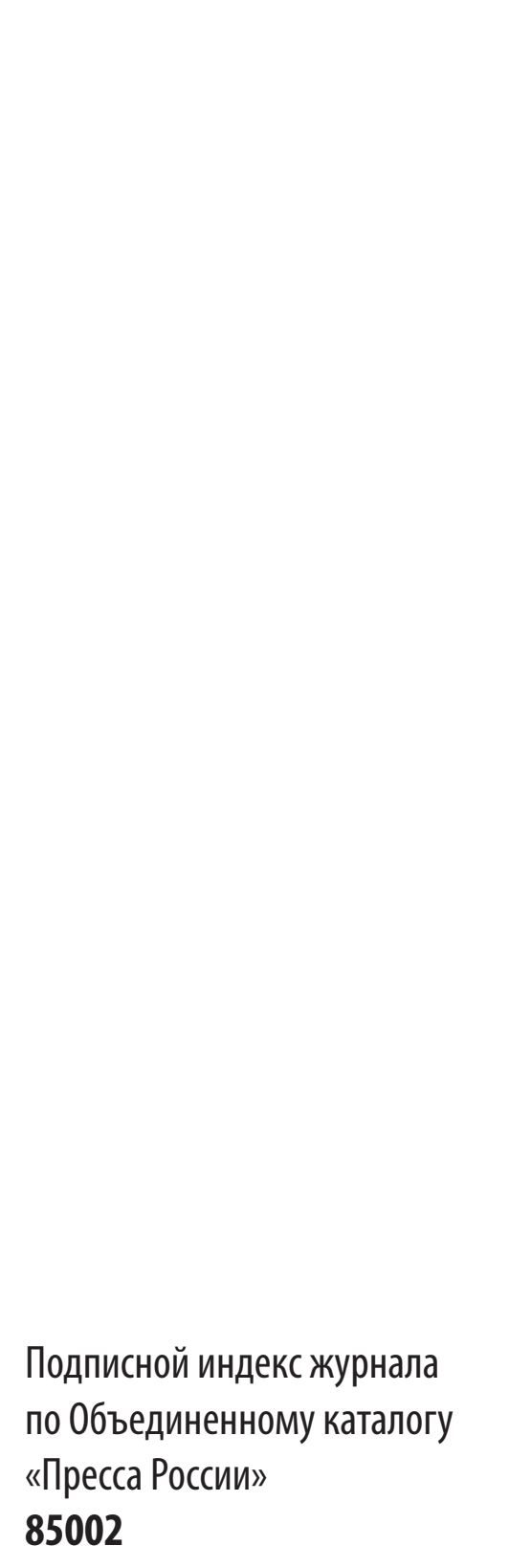

ISSN 2309-1428

2019

Tом (Vol.) 7

№ 1

\section{МУЗЫКАЛЬНОЕ ИСКУССТВО И ОБРАЗОВАНИЕ}

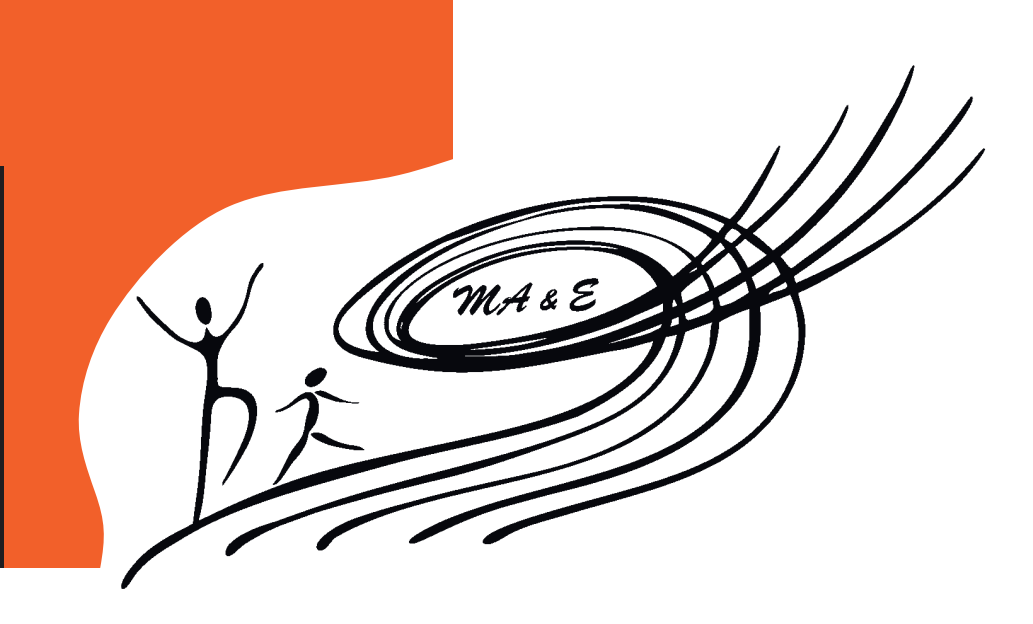




\section{МУЗЫКАЛЬНОЕ ИСКУССТВО и ОБРАЗОВАНИЕ}

\section{MUZYKALNOE ISKUSSTVO I OBRAZOVANIE}

\section{Научный журнал о мире музыкального искусства и образования $2019 \cdot 1$ \\ Журнал является рецензируемым изданием Издаётся с 2013 г. Выходит 4 раза в год
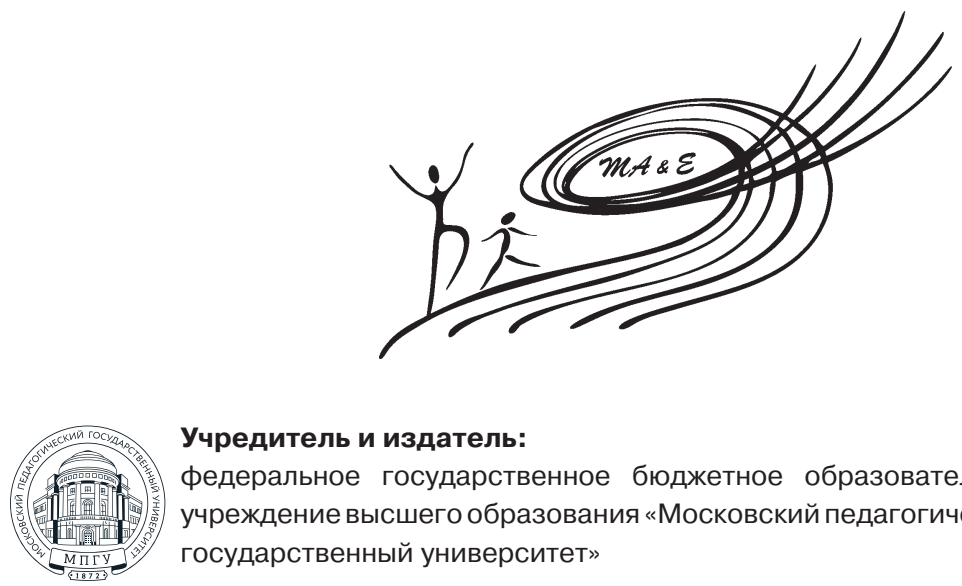

\section{Учредитель и издатель:}

федеральное государственное бюджетное образовательное учреждение высшего образования «Московский педагогический государственный университет»

Журнал входит в Перечень ведущих рецензируемых научных журналов и изданий Высшей аттестационной комиссии (ВАК).

До 2019 г. журнал выходил под названием: Вестник кафедры ЮНЕСКО «Музыкальное искусство и образование».

Журнал зарегистрирован в Федеральной службе по надзору в сфере связи, информационных технологий и массовых коммуникаций (Роскомнадзор). Свидетельство о регистрации ПИ № ФС77-75325 от 15 марта 2019 г.

Подписной индекс журнала по Объединенному каталогу «Пресса России» 85002.

Адрес редакции: 115172 г. Москва, Новоспасский переулок, д. 3, к. 3, Музыкальный факультет Института изящных искусств Московского педагогического государственного университета, оф. 203.

Тел.: +7 (495) 632-79-81

E-mail: metod-musik@yandex.ru

При полной или частичной перепечатке материалов ссылка на журнал «Музыкальное искусство и образование» обязательна.

Мнение редакции может не совпадать с мнением авторов. 


\section{РЕДАКЦИОННЫЙ СОВЕТ}

\section{Абдуллин Эдуард Борисович (председатель)}

доктор педагогических наук, профбессор, член Союза колпозиторов России Аубакирова Жания Яхияевна народная артистка Республики Казахстан, профессор

Барышева Талара Александровна

доктор психологических наук, проббессор

\section{Вудворд Шила}

доктор фбилособбии, адъюнкт-профбессор и директор департалента музыки Восточно-Вашингтонского университета (США), илен Президиума Международного общества музыкального образования (ИСМЕ)

\section{Гажили Ион}

академик-координатор фбилиала Академии наук Молдовы, доктор педагогических наук, проббессор

Гергиев Валерий Абисалович народный артист России, Почётный доктор, профбессор МГУ им. М. В. Ломоносова, почётный профбессор Московской и Санкт-Петербургской консерваторий

Гуревич Владилир Абралович доктор искусствоведения, проббессор, секретарь Союза композиторов РФ Дорбблан Леонид Яковлевич доктор психологических наук, професссор Кирнарская Дина Константиновна доктор искусствоведения, доктор психологических наук, член Союза композиторов России, член Союза журналистов России

\section{Мелик-Пашаев Александр Александрович}

доктор психологических наук

\section{Соколов Александр Сергеевич}

доктор искусствоведения, профбессор, илен Союза колпозиторов России Форрест Дэвид доктор фбилософбии, профбессор Университета Мельбурна (Австралия)

\section{Цыпин Геннадий Моисеевич}

доктор педагогических наук, кандидат искусствоведения, пробессор, член Союза колпозиторов России

\section{Щедрин Родион Константинович}

почётный профбессор Московской и Санкт-Петербураской консерваторий, колпозитор, народный артист СССР

\section{РЕДАКЦИОННАЯ КОЛЛЕГИЯ}

E. B. Николаева (главный редактор) - доктор педагогических наук, профессор

E. Д. Критская (залм. главного редактора) - кандидат педагогических наук, доцент

M. С. Осеннева (ответственный секретарь) - кандидат педагогических наук, доцент

Б. P. Иобис - кандидат педагогических наук, доцент

E. П. Красовская - кандидат педагогических наук, доцент

$\boldsymbol{A}$. B. Toponова - доктор педагогических наук, доктор психологических наук, профессор

Редакторы Ю. М. Севрюкова, А. А. Кравчук

Верстка Н. И. Лисова

Дизайн И. В. Нартова 


\section{U S I C A L ART and EDUCATION}

MUZYKALNOE ISKUSSTVO I OBRAZOVANIE

\section{Scientific Journal about the World of Music Art} and Education

The Journal is a peer-reviewed scientific publication The journal was founded in 2013 Comes out 4 times a year

\section{$2019 \cdot 1$}

Volume 7

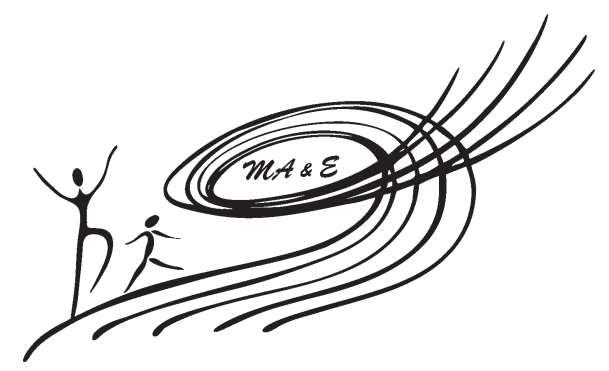

The founder and the publisher:

Federal State Budgetary Educational Institution of Higher Education

"Moscow Pedagogical State University"

Journal is included by Higher Attestation Commission of RF in the List of leading peer-reviewed scientific editions, published in the Russian Federation.

Until 2019 journal was published under the title: Bulletin of the UNESCO Chair "Musical Arts and Education".

The Journal is registered in the Federal Service for Supervision in the Sphere of Telecom, Information Technologies and Mass Communications (Roscomnadzor). Registration sertificate ПИ № ФС77-75325 March 15, 2019

Subscription index in the United Catalogue "Pressa Rossii" - 85002.

Adress: 115172, Moscow, Novospassky pereulok, 3-3, Department of Music, Institute of Fine Arts, Moscow Pedagogical State University, office 203.

Tel.: +7 (495) 632-79-81.

E-mail: metod-musik@yandex.ru

In case of partial or complete reproduction of the journal materials, the reference to "Musical Art and Education" Journal is mandatory.

Editor's views may differ from the authors' opinions. 


\section{EDITORIAL BOARD}

\section{E. B. Abdullin (chairman of the board)}

Doctor of Pedagogical Sciences, Professor, Member of the Union of Composers of Russia

J. Ya. Aubakirova

People's Artist of the Republic of Kazakhstan, Professor

T. A. Barysheva

Doctor of Psychological Sciences, Professor

\section{Ya. Dorfman}

Doctor of Psychological Sciences, Professor

D. Forrest

PhD, Professor at the Faculty of Arts of the Royal Melbourne Institute of Technology/RMIT University (Australia)

\section{Gagim}

Academician-coordinator of the Branch of the Academy of Sciences of Moldova, Doctor of Pedagogical Sciences, Professor

V. A. Gergiev

People's Artist of Russia

V. A. Gurevich

Doctor of Arts, Professor, Secretary of the Union of Composers of Russia

D. K. Kirnarskaya

Doctor of Arts, Doctor of Psychological Sciences, Professor, Member of the Union of Composers of Russian Federation, Member of the Union of Journalists of the Russian Federation

A. A. Melik-Pashaev

Doctor of Psychological Sciences

R. K. Shchedrin

Composer, People's Artist of the USSR

A. S. Sokolov

Doctor of Arts, Professor, Member of the Union of Composers of Russia

G. M. Tsypin

Doctor of Pedagogical Sciences, PhD in Arts, Professor, Member of the Union of Composers of Russia

Sh. Woodward

PhD, ISME Immediate Past-President, Associate Professor and Director of Music Education, Eastern Washington University

\section{EDITORIAL BOARD}

Nikolaeva E. V. (Editor-in-chief) - Doctor of Pedagogical Sciences, Professor

Kritskaya E. D. (Deputy Editor-in-chief) - PhD in Pedagogical Sciences, Associate Professor

Osenneva M. S. (Executive Secretary) - PhD in Pedagogical Sciences, Associate Professor

Iofis B. R. - PhD in Pedagogical Sciences, Associate Professor

Krasovskaya E. P. - PhD in Pedagogical Sciences, Associate Professor

Toropova A. V. - Doctor of Pedagogical Sciences, Doctor of Psychological Sciences, Professor

\section{Editors Yu. M. Sevryukova, A. A. Kravchuk}

Makeup N. I. Lisova

Design I. V. Nartova 
Научные направления издания по отраслям наук:

13.00.00 - Педагогические науки:

13.00.01 Общая педагогика, история педагогики и образования

13.00.02 Теория и методика обучения и воспитания (по областям и уровням образования)

13.00 .08 Теория и методика профессионального образования

19.00.00 - Психологические науки:

19.00.01 Общая психология, психология личности, история психологии

17.00 .00 - Искусствоведение:

17.00.02 Музыкальное искусство

\section{МЕТОДОЛОГИЯ ПЕДАГОГИКИ МУЗЫКАЛЬНОГО ОБРАЗОВАНИЯ}

Коптелова Т. И. Холизм и органическая фрилософия в современной музыкологии: поиск новой актуальной методологии . . . . . . . . . . . 9

Рева В. П. Практико-ориентированные стратегии погружения учащихся

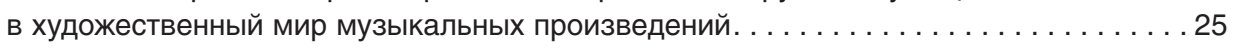

Овчинникова Ю. С. Концептуальные основы вузовского курса «Традиционная

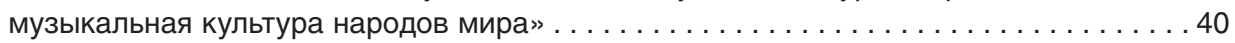

Молоствова И. Е. Технологические ориентиры мониторинга готовности студентов-музыкантов к художественно-интерпретационной деятельности . . . . . 60

МУЗЫКАЛЬНАЯ ПСИХОЛОГИЯ, ПСИХОЛОГИЯ МУЗЫКАЛЬНОГО ОБРАЗОВАНИЯ

Орлова Е. М. К истории отечественных программ по музыкотерапии:

В.М. Бехтерев - междисциплинарный подход в науке и образовании . . . . . . . . 78

\section{МУЗЫКАЛЬНОЕ ИСТОРИКО-ТЕОРЕТИЧЕСКОЕ ОБРАЗОВАНИЕ}

Энглин C. E. История и теория музыкальной письменности как учебная дисциплина. . . . . . . . . . . . . . . . . . . . 95

Путечева О. А. Феномен и семантика звука в современной музыке как предмет освоения в музыкальном образовании (на материале творчества Александра Бакши) . . . . . . . . . . . . . . . . . . . . . 107

Пивницкая О. В. Особенности реализации интонационного подхода в курсе фольклорного сольфеджио на примере русской традиционной культуры . . . . . . . 120 


\section{МУЗЫКАЛЬНОЕ ИСПОЛНИТЕЛЬСТВО И ОБРАЗОВАНИЕ}

Красовская Е. П. Развитие сосредоточенности будущего музыканта-педагога

в классе сольного музыкально-инструментального исполнительства . . . . . . . . . 132

\section{ИСТОРИЯ, ТЕОРИЯ И МЕТОДИКА МУЗЫКАЛЬНОГО ОБРАЗОВАНИЯ}

Дорошенко С. И. Теория музыкального воспитания первой трети XX века в контексте развития отечественной педагогики . . . . . . . . . . . . 153

Шумилова $\boldsymbol{E}$. H. Мотивация будущих музыкантов-педагогов к выбору заочной формы обучения и оценивание её современного состояния . . . . . . . . . . . 165 
The Journal is Devoted to the Following Scientific Fields:

Pedagogical Sciences $(13.00 .01 ; 13.00 .02 ; 13.00 .08)$

Psychological Sciences (19.00.01)

Art Sciences (17.00.02)

\section{METHODOLOGY OF PEDAGOGICS OF MUSICAL EDUCATION}

Koptelova T. I. The Holizm and Organic Philosophy in Modern Muzykologiya:

Search of New Relevant Methodology 9

Reva V.P. Practice-Oriented Strategies of Student Immersion in the Artistic World

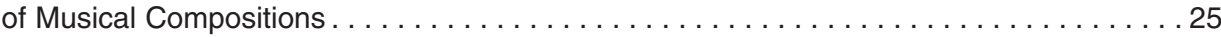

Ovchinnikova Yu. S. Conceptual Foundations of the Academic Course "Traditional

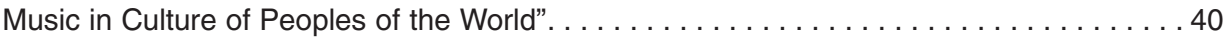

Molostvova I. Ye. Technological Terms of Monitoring the Readiness of Musician Students for Artistic-Interpretational Activities. 60

\section{MUSIC PSYCHOLOGY. THE PSYCHOLOGY OF MUSIC EDUCATION}

Orlova E. M. To the History of the National Programmes of Music Therapy:

V. M. Bekhterev - A Multidisciplinary Approach in Science and Education. . . 78

\section{MUSICAL HISTORICAL AND THEORETICAL EDUCATION}

Englin S. E. History and Theory of Musical Writing as an Academic Discipline 95

Putecheva O. A. The Phenomenon and the Semantics of Sound in Modern Music as the Subject of Development in Music Education (Based on Works by Alexander Bakshi)

Pivnitskaya O. V. The Peculiarities of Intonational Approach Realization within the Course of Folk Solfeggio Based on Russian Traditional Culture 


\section{MUSICAL PERFORMANCE AND EDUCATION}

Krasovskaya E. P. Development of Concentration Future Musician-Teacher in the Class of Solo Musical and Instrumental Performance

\section{HISTORY, THEORY, AND METHODOLOGY OF MUSIC EDUCATION}

Doroshenko S. I. Theory of Musical Education of the First Third of the XX Century in the Context of Development of Domestic Pedagogy . . . . . . . . . . . . . . 153

Shumilova E. N. Motivation of Future Musicians-Teacher to the Choice of Distance

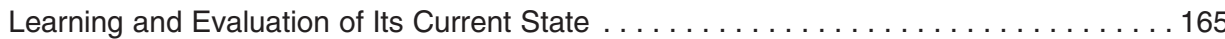




\section{ХОЛИЗМ И ОРГАНИЧЕСКАЯ ФИЛОСОФИЯ В СОВРЕМЕННОЙ МУЗЫКОЛОГИИ: ПОИСК НОВОЙ АКТУАЛЬНОЙ МЕТОДОЛОГИИ}

\section{Т. И. Коптелова,}

Нижегородская государственная сельскохозяйственная академия, Нижний Новгород, Российская Федерация, 603107

Аннотация. Предлетол исследования является фбилософбская парадигма совреленной методологии педагогики музыкального образования. Анализируются методологические возложности холизма и органической фбилософбии; особенности их приленения в музыкологии. При этол органическая фбилософия расслатривается как систела знаний, а также как интеллектуальная традиция, бокусируюшая внилание на ббункииональной иельности объектов действительности и законах живой природь. Речь идёт о необходилости изучения лузыки как явления духовной культурь, предполагающего единство человеческого разула, воображения и переживания. Раскрывается научный потенииал органической фбллософбии, которая позволяет исследовать всё множество национальных культурных парадигл, отражённых в совреленнол музыкальнол искусстве, и находить пути преодоления такой трудности, как иррациональное содержание музьки. Исследуются противоречия холизла и способь их разрешения в органической ббилособбии. Обосновьвается иелесообразность обращения к органической фбилософбии в сббере фборлирования новой методологии педагогики лузыкального образования, главной задачей которой является развитие творческой индивидуальности и раскрытие исполнительского таланта.

Ключевые слова: методология педагогики музыкального образования, музыкальное искусство, музыкальное образование, наука, парадигла органической ббилософии, творчество, холизл, эстетика.

Благодарности: Статья подготовлена в ралках научного направления исследования фбллософбских парадигл и методологии совреленного образования кафбедры "Филособбия, социология и политология" Нижегородской государственной сельскохозяйственной акаделии.

Для цитирования: Konтелова T. И. Холизм и органическая фрилософрия в современной музыкологии: поиск новой актуальной методологии // Музыкальное искусство и образование. 2019. Т. 7. № 1. С. 9-24. 


\title{
THE HOLISM AND ORGANIC PHILOSOPHY IN MODERN MUSICOLOGY: SEARCH OF NEW RELEVANT METHODOLOGY
}

\section{Tatyana I. Koptelova,}

Nizhny Novgorod State Agricultural Academy, Nizhny Novgorod, Russian Federation, 603107

\begin{abstract}
Object of research is the Philosophical Paradigm of modern methodology of pedagogics of music education. Methodological opportunities of a Holism and Organic Philosophy are analyzed; features of their application in a musicology. At the same time the Organic Philosophy is considered as the system of knowledge and also the intellectual tradition focusing attention on functional integrity of objects of reality and laws of wildlife. It is about need of studying of music as the phenomenon of spiritual culture assuming unity of human mind, imagination and experience. Scientific potential of Organic Philosophy which allows to investigate all set of the national Cultural Paradigms reflected in modern musical art is realized and to find ways of overcoming such difficulty as the irrational maintenance of music. Contradictions of a Holism and ways of their permission in Organic Philosophy are investigated. The expediency of the appeal to Organic Philosophy is proved in the sphere of formation of new methodology of pedagogics of music education which main task is development of creative identity and disclosure of performing talent. In this regard the integrating potential of Organic Philosophy, her ability through a phenomenon of life to connect all available and inaccessible to human consciousness is shown in the scientific article. The Organic Philosophy allows art to speak about science not only language of artistic image, but also from a position of conscious feeling (an altruistic love).
\end{abstract}

Keywords: methodology of pedagogics of music education, music art, music education, science, Paradigm of Organic Philosophy, creativity, Holizm, esthetics.

Acknowledgements: The article is prepared within the framework of the scientific direction of research of philosophical paradigms and methodology of modern education of the department "Philosophy, Sociology and Political Science" of the Nizhny Novgorod State Agricultural Academy.

For citation: Koptelova T. I. The holism and organic philosophy in modern musicology: search of new relevant methodology. Muzykal'noe iskusstvo $i$ obrazovanie = Musical Art and Education, 2019, vol. 7, no. 1, pp. 9-24. 


\section{Введение}

Музыка как цельное явление духовной культуры предполагает слышание, видение, воображение и переживание. Её чувственная и ращиональная составляющие, безусловно, требуют комплексного подхода в изучении, а смена фрилософрской, научной и культурной парадигм в начале XXI века способствует формированию новых методологических приёмов в познании музыкального искусства. Справедливо замечание о том, что наука о музыке не может довольствоваться достигнутой механистической парадигмой «и останавливаться в поиске других, более адекватных подходов и методов изучения и изложения своего предмета - музыки как звучащего живого явления» [1, с. 37]. Поэтому в начале XXI века перед музыкологией открывается широкий горизонт новых возможностей: формирование более актуальной методологии, опирающейся на современные философрские парадигмы; переосмысление науки о музыке с точки зрения других феноменов духовной культуры (самого искусства и религии). Понятие «музыкология» направляет исследователей не только к узкому рациональному познанию музыки (как, например, музыкознание), но и к философрскому Логосу, соединяющему человеческий разум с воображением и переживанием. Именно музыкология позволяет решать задачу успешного изучения проблемы педагогики музыкального образования на фрилософском (в том числе культурологическом) уровне, что сегодня особенно актуально [2, с. 18-19].

В начале XXI века необходима новая методология изучения музыки, которая поможет не только сформулировать, но и найти ответы на вопросы: 1) что такое цельность музыкального произведения? 2) какие измерения могут быть у музыки? 3) какие возможности открываются перед слушателем и перед исполнителем музыки? 4) в чём заключается универсальность и самобытность музыки? 5) как музыка соединяет в себе динамику и статику, диалектику и метафизику? 6) какое место занимает музыкология среди других наук в постнеклассической парадигме? 7) как преодолеть основные трудности и противоречия в изучении современного музыкального искусства? 8) что представляет собой динамическая методологическая модель педагогики современного музыкального образования? И новая эпоха, безусловно, сформулирует большое количество вопросов, ответы на которые окажутся решающими в формировании мировоззренческой парадигмы молодого поколения - как будущих музыкантов, так и любителей музыки.

Философрские парадигмы разнообразны, и, несмотря на господство механицизма в классической науке, одной из интеллектуальных традиций Европы когда-то была органическая фрилософия. Логика органического, основывающаяся на законах живой природы, актуальна в изучении френоменов духовной культуры. Именно она помогает восстановить функциональную целостность в области этики и эстетики, возродить синкретизм искусств, используя для оценки человеческого творчества не только универсальные (абстрактные) термины современной науки, но и творческое видение, индивидуальное переживание духовных смысло- 
вых принципов, воплощённых в различных памятниках культуры.

\section{Различные философские парадигмы в методологии педагогики современного музыкального образования}

В методологии педагогики музыкального образования начала XXI века можно увидеть отражение различных фоллософских парадигм, таких как:

а) лиеханиизл (классическое изучение музыкальных текстов по письменному материалу);

б) транслеханииизл, или постнеклассическая парадигма, или постмодернизм (исследование сонорики музыкального авангарда XX века);

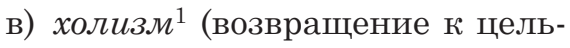
ности музыкальных произведений, признание иррациональной составляющей в музыкальном искусстве);

г) парадигма органической фбилософбии (интегративная методика, позволяющая «соборно» сочетать различные национальные педагогические традиции в музыкальном искусстве, применять методы перенимания и подражания).

Органическая фрилософрия представляет собой систему знаний, особую методологию, основывающуюся на логике органического (живого), а также интеллектуальную традицию, фокусирующую внимание на фрункциональной цельности явлений действительности и законах живой природы. При этом можно выделить следующие этапы развития человеческого мышления европейской культуры, сопровождающиеся господ- ством той или иной интеллектуальной традиции:

1) наивно-органический - период, включающий в себя Античность и Средневековье (с VI века до н. э. по XIV век н. э.);

2) механистически-органический время недолгой гармонии, когда развивающаяся рациональность была немыслима без цельности и органичности (XV-XVI века - эпоха Возрождения);

3) механистический (Европа XVII$\mathrm{XX}$ веков - интенсивное развитие техники, превращение науки в планетарное явление);

4) транслеханистический (конец XX - начало XXI века - планетарное распространение технологий и постнеклассического стиля мышления) [3, c. 264].

Механицизм как наиболее характерный для европейской цивилизации стиль мышления, доминирующий в науке, фрормирует особую методологию, ярко выраженную в классическом рациональном познании конца XVII - начала XIX века (например, законы и принципы научного познания И. Ньютона). Диалектика XIX века выходит за рамки механистического стиля мышления, но оказывается порой бессильной перед спонтанностью и фрункциональной целостностью, а также испытывает влияние количественного метода механицизма. Несовершенство диалектической методологии выражается и в отсутствии смыслового ряда градаций между противоположностями, в искусственном уравновешивании несоразмерных категорий. Трансмеха-

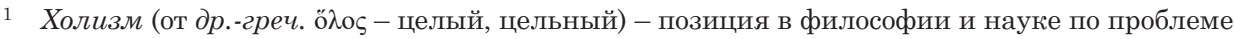
соотношения части и целого, исходящая из качественного своеобразия, приоритета целого по отношению к его частям. 
ницизм XX века находит своё воплощение в постмодернизме и плюрализме «квантового» стиля мышления и создаёт иллюзию относительности, безразличия, что ведёт к нивелировке ценностей духовной культуры.

Логика органического, напротив, сохраняет незыблемым важнейший принщип духовной сореры - жизнеутверждение. Она характеризует стиль мышления, существовавший в разное время и существующий сегодня в неповторимых национальных культурных традициях (гилозоизм, витализм, «цельное знание», органицизм, органический тип фрилософрии истории, холизм и т. д.). Основы органической фрилософрии формировались, с одной стороны, благодаря развитию наук о живой природе (теория порядка Г. Дриша [4, с. 163-178], русский космизм и учение В. И. Вернадского о ноосфере [5, с. 382-458], теория ортобиоза И. И. Мечникова [6, с. 238245], геософрия евразийства 20-30-х годов XX века [7, с. 13-78] и теория этногенеза Л. Н. Гумилёва [8, с. 471514]), а с другой стороны, - под влиянием русской христианской традиции («органическая логика» В. С. Соловьёва [9, с. 279-283]).

Музыкант-педагог, определяя эстетическое, нравственное, общедуховное содержание господствующих в начале XXI века музыкальных парадигм, неизбежно сталкивается с рядом проблем, корни которых уходят в предшествующие столетия. Одна из них - это утрата жизнеутверждающего, оптимистического мировоззрения. Подобную проблему позволяет вскрыть органическая философия, а сама утрата альтруистического жизнеутверждения обусловлена господством механицизма. Жиз- неутверждающее мировоззрение как вдохновение, идущее от эпохи Возрождения, ярко проявилось в классической европейской музыке XVIIIXIX веков, в её уникальной гармонии, передающей импульс любви и сострадания.

Другая проблема, неразрывно связанная с развитием музыкального искусства в XX веке, - это неудержимое стремление превратить местные национальные традиции в глобальное, планетарное явление. И раскрыть эту проблему поможет трансмеханицизм, унифицирующий и трансформирующий искусство в технологию, провозглашающий глобализм во всём. При этом важно помнить, что претензия на глобализм пришла в музыку благодаря подражанию европейской культуре, отстаивающей «общечеловеческий характер». Почему культуры других народов не могут приобрести общечеловеческое значение, тем более что сам процесс глобализации и развитие средств массовых коммуникаций позволяют планетарно распространять любые локально возникшие духовные ценности? И это при том, что некоторые современные музыкальные парадигмы, возникшие на основе местных национальных традиций, претендуют на мировое распространение, например «негритянский» джаз и многие другие.

Ещё одна проблема в исследовании современного музыкального искусства, которую нельзя решить без привлечения различных фрилософрских парадигм, связана с анализом очень широкого спектра эстетических установок музыки, включающего не только классическую традицию и авангард XX века, но и множество 
джазовых стилей, эстрадную музыку, звуковое оформление кинофильмов и бесконечного количества медиапродуктов, электронно-механическую музыку и т. п. Разнообразие в музыкальном искусстве не может не радовать, хотя и требует дополнительных усилий и расширения методологии.

Большим потенциалом в разработке новой методологии обладает органическая фрилософия. Именно она позволяет видеть всё множество национальных культурных парадигм, отражённых в современном музыкальном искусстве, и находить пути преодоления такой проблемы, как иррациональное содержание музыки. Так, порой невозможно словесно передать глубинную сущность музыкального произведения, а язык художественного образа настолько богат, что способен выразить вечные духовные запросы человечества. Этот язык можно назвать динамическим, поскольку он вобрал в себя все три измерения времени: прошлое, настоящее и будущее [10, с. 15-16]. Но динамика всегда сталкивается с метафизикой (статичностью) вечных духовных идеалов. И это ещё одна трудность в изучении музыки как духовного явления.

Парадигма органической фоллософии позволяет приблизиться к разгадке цельности, монолитности произведений классического музыкального искусства через процессуальность (единство времени, где настоящее определяется будущим) и постоянство (статичность) эстетического идеала. Органическая фрилософия помогает переосмыслить френомен песенной формы, раскрывающей гармонию музыкального произведения в сочетании динамического и статического языков, иррациональности и рациональности человеческого переживания. С точки зрения органической фрилософии классическую музыку XVII-XIX веков можно считать своеобразным выражением зрелости человеческого разума («разумной верой» и «разумным чувством»), а песенную форму - преодолением противоречий объективного и субъективного в музыке, достижением созвучности индивидуальности автора и слушателя, указанием на общеродовое начало любого человеческого творчества. Творчество всегда подразумевает переживание, полное погружение в предмет или процесс, подражание и причастность чему-либо (обострённую чуткость). И всё это всегда происходит в контексте определённого пространства и времени, с оттенком сопричастности к судьбе того или иного народа. Поэтому с точки зрения органической фрилософии музыка будущего неизбежно потребует от нас перенесения акцента с сонорики (именно в этой области находится важнейший эстетический принцип музыки XX века) на сфреру чувств, переживаний - процессуальности, которая возможна лишь при наличии песенной формы. Именно чувства, вызываемые музыкой, можно назвать четвёртым измерением музыкального произведения, его подлинной глубиной, наряду с условной вертикалью гармонии, горизонталью мелодии, механическим наполнением - сонорикой (преимущественно техникой современной музыкальной композиции, оперирующей темброзвучностями) [11, с. 110-114].

Именно органическая фрилософия позволяет осознать одновременность завершённости и бесконечно- 
сти музыкального произведения через внутреннюю непрерывность гармонии и цельность человеческого переживания. Так, форма в музыке создаётся и воссоздаётся через яркое исполнение, индивидуальное интонирование, открывающее всё новые качества даже хорошо известного произведения [12, с. 9].

Органическая фрилософия позволяет выявить следующие законы существования и развития музыкального искусства: 1) закон саморазвития, полагающий, что жизнеспособность нового музыкального произведения определяется его цельностью (об этом свидетельствует песенная форма); 2) закон многообразия, показывающий, что музыкальные шедевры создают предпосылки для появления новых, неповторимых творений художников и музыкантов (пример - классическая музыка XVII-XIX веков, порождающая жизнеутверждающие импульсы, идущие сквозь века); 3) одновреленное действие двух детерлинаций (причинной, идущей от прошлого, и целевой - детерминации будущего), приближающее к тайне спонтанности в рождении нового музыкального произведения [13, с. 42-43].

В отличие от холизма органическая фрилософия оказалась менее подверженной влиянию европейского механицизма.

\section{Холизм и органическая философия: преодоление противоречий в познании музыкального искусства}

Холизм содержит в себе противоречия, преодоление которых возможно при помощи органической фрилософии. Такими противоречиями являются: 1) абсолютизаџия динамики и отрицание всяких абсолютов; 2) противоречие между "текучестью» ценностей и незыблемостью духовных приоритетов; 3) признание одновременного состояния развития мира и его цельности как всеобщей завершённости (противоречие статичности и динамичности); 4) противоречие между высшим и низшим, целым и частью в мироздании; 5) создатели холизма отвергают механицизм, но следуют его принципам; 6) признание одновременно «голографического образа» устройства мира (унификация) и многообразия; 7) наука об искусстве рассматривается как высшее интеллектуальное достижение, а искусство о науке - как художественный образ, выходящий за рамки рационального осознания.

Абсолютизаиия диналичности, развития и отношений/соотношений осуществляется в духе постнеклассической, «квантовой» парадигмы. При этом многие исследователи в самых разных областях отстаивают принцип динамичности как наиболее верный, лишённый недостатков. Например, в динамической музыкологии предлагается «переход от предметов к их соотношениям. Любой объект должен быть определён не сам по себе, а в его отношениях с другими объектами» [1, с. 37]. Такой подход способствует рассмотрению любой духовной ценности как относительного явления (или процесса) и не позволяет устанавливать самоценность предмета вне других объектов и отношений. $B$ этол случае отсутствует незыблельй духовный идеал, к которолу обращено творческое стрелление ("идеально», ценно не само по себе, а в зависимости от того, как к этому стремятся люди, 
какое место предмет занимает в человеческих отношениях). Поэтому становятся относительными, «текучими» такие категории, как «истина», «красота», «добро» (их смысл устанавливается через отношения). Так разрушаются каноны в музыкальном образовании, размывается представление о классике, о самоценности даже самых выдающихся произведений искусства. Они превращаются либо в некий бездушный материал, либо в фоновую музыку (во что-то второстепенное, устаревшее, неактуальное) [14, с. 135-138]. Подобное отвечает духу постмодернизма, развивает в человеке чувство безответственности, потому что всё вокруг неустойчиво, относительно.

Органическая философия, в противоположность культуре постмодернизма, способствует возрождению духовных традиций и таких ценностей, которые на протяжении многих веков помогали людям ощущать всю полноту жизни. Творческое прочтение вечных истин - это ключ к пониманию прошлого, настоящего и будущего. Выдающийся русский фрилоcoф, представитель евразийства 2030-х годов прошлого столетия Г. В. Флоровский предложил идею «неопатристического синтеза» (современное творческое понимание и переживание духовного опыта, накопленного Отцами Церкви в первые века нашей эры, возрождение изначальных духовных ценностей христианства [15, с. 37]). Поскольку органическая фрилософия сочетает статичность (незыблемость, завершённость в цельном мироздании, всеобщность) и динамичность (индивидуальное творческое переживание) духовных ценностей, то примени- тельно к педагогике современного музыкального образования становится актуальной возможность «неоклассического синтеза» в музыке создания в современной музыкальной эстетике представления о новой классике, продолжающей традиции XVII-XIX веков. Основанием для такого синтеза, с одной стороны, может стать уникальная гармония, органично сочетающая иррациональное и рациональное начала в классической европейской музыке XVII-XIX веков, а с другой - творческая энергия и стремления современного поколения [11, с. 102-103].

Однил из недостатков приниипа диналичности в холизле является ешё и то, что мы ложел изучать иелое (лир, Вселенную) только через отношения его элелентов. Холизм подводит к заключению: выделяемые человеком явления и объекты имеют смысл только в составе целого. Почти ничего холизм не может сказать о завершённости целого и о возможности его полного и окончательного познания. «Завершённость», «полнота» и «абсолютность» это метафизические категории, которые выходят за рамки холизма, но находят новое прочтение в органической фрилософиии. Опираясь на открытия современной фризики (опыты, проведённые в 1980-х годах фрранцузским фризиком Аленом Аспектом, открыли мгновенную взаимосвязь микрочастиц, названную «нелокальностью», и позволили сделать вывод, что все квантовые частицы в мироздании, находящиеся или когда-либо находившиеся в одном состоянии, остаются внутренне связанными друг с другом [16]) и генетики (все клетки организма прои- 
зошли из одной, поэтому тождественны по ДНК), органическая фрилософия рассматривает летаббизическое состояние как момент рождения и завершения Вселенной (метафизическое «всеединство» В. С. Соловьёва [9, с. 279-283]).

«Метафизика» - термин Аристотеля, призванный обозначить то, что было до появления фризического мира (начало) и что будет после него (конец) [17, с. 77-85, 195-197]. Современная физика, теория Большого Взрыва, допускает такое изначальное положение Вселенной, когда все элементы в ней находились в одном состоянии, в наивысшей степени цельности и были, как никогда, родственны друг другу. Поэтому органическая фрилософия предлагает рассматривать бесконечность как непрерывность, состояние вне времени и пространства. Соединяя динамический принцип с метафизикой, органическая фрилософия рассматривает момент рождения (начало) и цель (завершение, конец Вселенной) как жизнь в полном значении этого слова - жизнь, наполненную гармонией, состояние, когда каждый элемент мироздания может чувствовать себя, как все (как всякий другой), и в то же время все элементы способны находиться в таком состоянии, как каждый по отдельности. Отражение подобного состояния можно увидеть в миметическом принципе искусства, когда на уровне человеческой личности, выражающей наивысшую доступную нам степень цельности, каждый может стать всем и всё каждым; при этом сохраняется многообразие и возможность бесконечного числа перевоплощений и не происходит унифрикации. Так, «соприка- саясь с другими судьбами, с предметами, уподобляясь им, артист в то же время не теряет собственного лица (он должен оставаться собой) - в этом и заключается загадка, тайна игры» [18, с. 101].

Органическая фбилособбия снилает противоречия части и иелого, диналичности и статичности в понилании явлений культурь и салого мироустройства. Миметический принцип искусства в парадигме органической фрилософрии - это наивысшее проявление завершённости (статики) и пластичности (динамики). Слово «мимесис» (или «мимезис») происходит от древнегреческо-

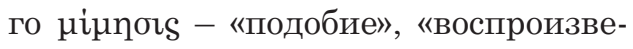
дение», «подражание». И, как известно, именно искусство заражает эмоциями, и через подражание происходит приобщение. При этом подлинное подражание (в органической фрилософии) - это не простое копирование чужого, а творческое сопереживание, превращение чего-то внешнего в собственное внутреннее чувство. Именно поэтому искусство отделяется от других форм человеческой деятельности, от того, что древние греки называли словом «технэ»

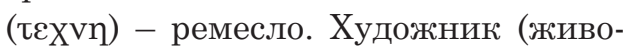
писец) отделяется от ряда, который составляют плотник, гончар, сапожник и др. Дело в том, что искусство не учит «практической мудрости» (оно и не наука, и не философия). Но искусство нельзя отождествлять и с моралью. Самое ценное в искусстве - это возможность приобщения через игру, подражание. И, в понимании Платона, подлинное подражание - это стремление к идеалу (абсолютной нематериальной сущности предмета), а не копирование ко- 
пий, то есть воспроизведение вещей чувственного мира (пустое тиражирование или обман - замена подлинника копией) [19, с. 205-217].

Благодаря органической фрилософии можно выделить такую проблему холизма, как абсолютизацию целостности, приводящую к отрыву высшего от низшего в структурном и в генетически-эволюционном отношении. Подобное делает невозможным познание современными научными средствами высших проявлений бытия (например, ценностей духовной культуры, органической живой материи, психологических и социальных систем). Такое методологическое основание холизма ведёт к противопоставлению иррационального и рационального аспектов познания, где рациональное является приоритетным и единственно возможным для научного постижения предмета. Поэтому за рамками методологии холизма остаются цельность человеческой личности (невозможность сочетать разум и чувства) и единство творческого процесса. B противопоставлении высшего и низшего холизл невольно продолжает механистический подход. Так, система в механицизме составляется, а цельность (образ) в органической фрилософрии рождается. И способность к развитию у живого организма проявляется в том, что он остаётся самим собой и одновременно меняется. Таким образом, цельность проявляется и сразу, и разворачивается во времени. Органическая боллособия не противопоставляет высшее и низшее в составе иелого, поскольку они не сушествуют друг без друга и всегда связань общей иелью, которой является салиа жизнь.
Применительно к педагогике современного музыкального образования механистический подход и холизм заключаются в том, что процесс обучения, с одной стороны, представляет собой единое целое, а с другой неизбежно состоит из этапов (ступеней), где есть низший и высший уровни обучения. Органическая фолософия позволяет обогатить методику поэтапного освоения любого вида музыкального искусства через развёртывание (реализацию) индивидуального исполнительского таланта. Именно идея (идеал), образ способны соединить все этапы обучения, стать единой связующей «красной нитью». Реализация индивидуального таланта предполагает раскрытие личности, обретение в творчестве самого себя и в то же время приобщение ко всему многообразию мира искусства.

Другая проблема холизма - одновреленное признание «голографбиеского образа" устройства лира (унифбикация) и многообразия. Действительно, термин "голограмма" пришёл из фризики и предназначен для обозначения (описания) некой цельности материального мира. А как быть с духовным? Цельность это единица, единство и завершённость. В механистической парадигме, основанной на математическом исчислении, единица чаще используется не для обозначения суммы, а для отдельной части целого. Органическая фрилософия предполагает, что цельность несёт в себе жизнь, а жизнь всегда многообразна, способна к развитию, спонтанности, рождению нового. Образ голограммы, предлагаемый холизмом для понимания Вселенной, неизбежно приво- 
дит к выводу: при делении Вселенной на части мы получаем не отдельные разнообразные элементы, а её уменьшенные копии. Человек в своём сознании и предметной деятельности постоянно имеет дело с делением мира (аналитика и конструирование). Также человечество к началу XXI века сорормировало настолько обширную техносферу, что она начинает угрожать существованию биосферы. Техника, орудия труда и машины от всего живого отличаются тем, что они не способны к саморазвитию без участия человека. Считать такие объекты копиями Вселенной, обладающими цельностью, невозможно, хотя мир техники способен существовать по единым стандартам, но общая детерминация будущего, которая движет в настоящее время техносферой, - это унификация. А конец всякой унификации ничто, пустота, отсутствие жизни. Таким образом, можно сделать вывод, что Вселенная делима в сознании и материальной деятельности человека, но не все выделяемые элементы обладают цельностью и могут претендовать на звание уменьшенной копии всего целого. Цельность характеризует живые организмы. Органическая философия предлагает методологию, согласно которой и народ (этнос), и национальная культура могут быть исследованы по аналогии с живыми организмами. Безусловной духовной и материальной цельностью с точки зрения органической фрилософии обладает человеческая личность. Этот подход представляется в настоящее время наиболее плодотворным в изучении творчества и явлений духовной культуры. Так, уникальная цель- ность человеческой личности может быть сопоставима со Вселенной.

Цельность каждой отдельной человеческой личности находится в процессе творческого становления на протяжении всей индивидуальной жизни, поэтому можно говорить о свободе выбора, о спонтанности развития, о возможности появления нового в культуре. Именно творческое становление личности рождает многообразие в духовной культуре. Холизм предлагает голографическую модель мира, вполне отвечающую современной постнеклассической научной парадигме, но слишком узкую для духовной культуры. Органическая фбилософбия даёт возможность расслатривать духовныци мир как иелостность, реализуюшую линогократно превышающий скорость света способ передачи всей иельности (всей полноть) инфорлации, всей любви, способ организации молниеносной связи всего со всел. Таким образом, духовный мир в парадигме органической фрилософиии - это не просто поле (следуя идеалу современной фризики и надежде на создание общей теории полей). Духовный мир - это соединение индивидуального с лногообразиел и всеобшностью, своеобразный путь от индивидуальности - и через многообразие - $к$ всеобшности.

В отличие от холизма, органическая фбилособбия содержит в себе не только научный, но и художественныцй, и религиозный аспекты. Её можно считать интеллектуальной целостностью, включающей в себя математический, холодный разум, волевое оптимистическое, жизнеутверждающее стремление и альтруистическую любовь (чувство). Такая 
интеллектуальная цельность (интеллектуальная потому, что осознанная) воплощается не только в фрилософии (в науке вообще), но и в искусстве, религии. Поэтому современная педагогика музыкального образования включает в себя не только науку об искусстве (музыкознание или фрилософию музыки - музыкологию), но также искусство о науке (методические приёмы будут всегда опробованы в практике исполнительского искусства или искусства слушания музыки).

Невозможно исключить из педагогики и религиозный аспект, поскольку он может быть неотъемлемой частью мировоззрения музыканта и слушателя. С позиции религиозного философра И. А. Ильина, подлинное искусство - это "всё чистое и глубокое, благородное и художественное», незримо навеянное силой Господа, «ещё не открывшегося человеческому сознанию, но таинственно вдохновляющего человеческие сердца» [20, с. 7]. Религия может говорить об искусстве, раскрывая границы человеческого разума через осознание переживания восторга и радости, умиления и сочувствия, через ощущение драматичности мироздания и его тайны.

Для русского искусства, как правило, характерно "разумное чувство». Так, например, некоторые исследователи главной ценностью русской школы духовной музыки считают «осознание исполнителем смысла музыкальной фразы, её содержания» [21, с. 130]. Духовность как надприродную (метафизическую) сущность человека невозможно изучать при помощи одной только науки в осознании духовных феноменов по- могают искусство и религия. При этом важно помнить, что картина мира (парадигма) каждой отдельной эпохи формируется благодаря не только научным достижениям, но и культуре в целом (под влиянием искусства и религии).

\section{Заключение}

Различные фрилософские парадигмы выступают как части целого, позволяя рассматривать и понимать отдельные фрагменты реальности. Наибольшей интегрирующей способностью в начале XXI века обладает органическая фрилософия, поскольку в центре её внимания сам феномен жизни, соединяющий всё доступное и недоступное человеческому сознанию. Органическая фрилософия позволяет сформулировать следующие методологические принципы изучения музыкального искусства:

1) неисчерпаемое многообразие национальных культурных парадигм;

2) соединение динамичности музыки со статичностью (неизменностью) духовных идеалов;

3) раскрытие динамичности музыкального искусства в индивидуальном переживании, «прочтении» музыкального произведения исполнителем или слушателем;

4) песенная форма существования музыкального искусства;

5) принцип четырёх условных измерений музыкального искусства (переживание - чувство (глубина); вертикаль - гармония; горизонталь - мелодия; механическое наполнение/ разъятие - сонорика);

6) принцип цельности - поиск согласования культурного разнообразия как возможность более широкого взгляда на мир; это путь пре- 
одоления противоречий (смысловой разорванности);

7) наивысший миметический смысл музыкального искусства - приобщение индивидуальности к многообразию и всеобщности;

8) принцип органической цельности поэтапного обучения - развёртывание (реализащия) индивидуального таланта обучающегося через оптимистически-альтруистическое стремление к высшему и совершенному.

При этом органическая фрилософия позволяет объединять научный, художественный и религиозный подходы в изучении духовных феноменов культуры, даёт возможность искусству говорить о науке не только языком художественного образа, но и с позиции "разумного чувства» (оптимистического жизнеутверждения, альтруистической любви). На музыкальное искусство можно смотреть с точки зрения отдельных наук (физики, истории, психологии и т. д.). И даже современное естествознание некоторые учёные предлагают исследовать с позиции музыки. В част- ности, для разъяснения природы органической связи биофизик Мае-Ван Хо предложила использовать в качестве примера танцевальную группу или джазовый оркестр [22, с. 19-20]. Таким образом, органическая философия открывает путь к новой методологии педагогики музыкального образования и определяет музыкологию как интегральную науку.

Достаточно перспективной представляется и «динамическая музыкология», прокладывающая дорогу к новой парадигме музыкального искусства в начале XXI века. Важно помнить, что любая традиция, культурная парадигма, научная методология всегда существуют в рамках своего пространства и времени, позволяя решать насущные вопросы, но вне этих рамок присутствуют вечные всеобщие идеалы - жизнеутверждение и альтруистическая любовь. Главная особенность подлинного произведения искусства - способность существовать и в рамках времени-пространства, и вне всяких границ и преград. В этом и заключается его вселенская цельность.

\section{БИБЛИОГРАФИЯ}

1. Гажим И. «Динамическая музыкология» как синтез и актуализация основополагающих учений в области теории музыки // Вестник кафедры ЮНЕСКО «Музыкальное искусство и образование». 2017. № 1 (17). С. 33-44.

2. Николаева Е. В. Вестник кафедры ЮНЕСКО «Музыкальное искусство и образование»: к пятилетнему юбилею вхождения в международное научно-информационное пространство // Вестник кафедры ЮНЕСКО «Музыкальное искусство и образование». 2018. № 1 (21). C. 13-24.

3. Коптелова Т. И. Классическая музыка в парадигме органической философии: детерминация будущего // Вестник ЛГУ им. А. С. Пушкина. 2016. № 3. С. 259-269.

4. Дрии Г. Витализм. Его история и система. М.: Наука, 1915. 280 с.

5. Вернадский В. И. Биосфера и ноосфера. М.: Айрис-Пресс, 2004. 576 с.

6. Мечников И. И. Этюды о природе человека. М.: Изд-во Академии наук СССР. 1961. 290 с.

7. Савиикий П. Н. Континент Евразия. М.: Аграф, 1997. 464 с. 
8. Гумилёв Л. Н. Этногенез и биосфера Земли. М.: АСТ, 2001. 560 с.

9. Соловьёв В. С. Полное собрание сочинений и писем: в 20 т. Т. 2. Сочинения. 1875-1877. М.: Наука, 2000. 395 с.

10. Коптелова Т. И. Музыка как отражение жизни: органическая методология изучения музыкального искусства // Вестник кафедры ЮНЕСКО «Музыкальное искусство и образование». 2016. № 3 (15). С. 13-20.

11. Коптелова Т. И. Музыкальная эстетика XXI века в парадигме органической философии // Философская мысль. 2017. № 9. С. 101-114.

12. Асафьев Б. В. Путеводитель по концертам. Изд. 2-е. М.: Советский композитор, 1978. 200 с.

13. Коптелова Т. И. Коммерция против искусства: театрально-эстрадное шоу в механистической и органической философских парадигмах // Философия хозяйства. Альманах Центра общественных наук и экономического факультета МГУ имени М. В. Ломоносова. 2018. № 2 (116). C. 39-48.

14. Холопов Ю. Н. Новые парадигмы музыкальной эстетики XX века // Эстетика на переломе культурных традиций. М.: Изд-во ИФ РАН, 2002. С. 132-147.

15. Флоровский Г. Восточные Отцы Церкви. М.: АСТ, 2003. 633 с.

16. Аспект A. Теорема Белла: наивный взгляд экспериментатора / пер. с англ. П. В. Путенихина. 2007. URL: http:/quantmagic.narod.ru/volumes/VOL422007/p2135.html (дата обращения: 23.05.2018).

17. Аристотель. Метафизика / пер. с греч. П. Д. Первова и В. В. Розанова. М.: Изд-во Института философии, теологии и истории св. Фомы, 2006. 232 с.

18. Коптелова Т. И. Театрально-эстрадное шоу в парадигме органической философии (на примере шоу «Игра» Николая Баскова) // Наука. Мысль. 2017. № 4. С. 96-103.

19. Асмус В. Ф. Платон. М.: Мысль, 1969. 242 с.

20. Ильин И. А. Основы христианской культуры. URL: http://rusk.com.ru/lib/prav/iljin-osnovy_ kultury.html (дата обращения: 23.05.2018).

21. Попов В. С. Русская школа духового исполнительства // Вестник кафедры ЮНЕСКО «Музыкальное искусство и образование». 2017. № 3 (19). С. 123-132.

22. Mae-Wan Ho, Saunders P. Beyond Neo-Darwinism: An Introduction to the New Evolutionary Paradigm. London: Academic Press, 1984. 376 p.

Поступила 07.06.2018; принята к публикации 27.02.2019.

Об ав торе:

Коптелова Татьяна Ивановна, доцент кафедры философии, социологии и политологии ФГБОУ ВО «Нижегородская государственная сельскохозяйственная академия» (проспект Гагарина, 97, г. Нижний Новгород, Российская Федерация, 603107), кандидат фрилософрских наук, доцент, koptelova2210@rambler.ru

Автором прочитан и одобрен окончательный вариант рукописи. 


\section{REFERENCES}

1. Gagim I. "Dinamicheskaya muzykologiya" kak sintez i aktualizatsiya osnovopolagayushchikh uchenij v oblasti teorii muzyki ["Dynamic Musicology" As the Synthesis and Actualization of the Fundamental Teachings in the Field of Music Theory]. Vestnik kafedry UNESCO "Muzykal'noe iskusstvo i obrazovanie" - Bulletin of the UNESCO Chair "Musical Arts and Education”, 2017, no. 1 (17), pp. 33-44 (in Russian, abstract in English).

2. Nikolaeva E. V. Vestnik kafedry UNESCO "Muzykal'noe iskusstvo i obrazovanie": k pyatiletnemu yubileyu vkhozhdeniya $\mathrm{v}$ mezhdunarodnoe nauchno-informatsionnoe prostranstvo [Bulletin of the UNESCO Chair "Musical Arts and Education": the Five-Year Anniversary Entry into International Scientific and Informational Space]. Vestnik kafedry UNESCO "Muzykal'noe iskusstvo i obrazovanie" - Bulletin of the UNESCO Chair "Musical Arts and Education", 2018, no. 1 (21), pp. 13-24 (in Russian, abstract in English).

3. Koptelova T. I. Klassicheskaya muzyka $v$ paradigme organicheskoj filosofii: determinatsiya budushchego [Classical music in a paradigm of organic philosophy: determination of the future]. Vestnik LGU im. A. S. Pushkina [Bulletin of Pushkin Leningrad State University], 2016, no. 3, pp. 259-269 (in Russian, abstract in English).

4. Driesch G. Vitalizm. Ego istoriya i sistema [Vitalizm. His history and system]. Moscow: Nauka Publ., 1915. 280 p. (in Russian).

5. Vernadsky V. I. Biosfera i noosfera [Biosphere and noosphere]. Moscow: Ajris-Press Publ., 2004. 576 p. (in Russian).

6. Mechnikov I. I. Etyudy o prirode cheloveka [Etudes about human nature]. Moscow: Akademiya nauk SSSR Publ., 1961. 290 p. (in Russian).

7. Savitsky P. N. Kontinent Evraziya [Continent Eurasia]. Moscow: Agraf Publ., 1997. 464 p. (in Russian).

8. Gumilev L. N. Etnogenez i biosfera Zemli [Ethnogenesis and Earth' biosphere]. Moscow: AST Publ., 2001. 560 p. (in Russian).

9. Solov'ev V. S. Polnoe sobranie sochinenij i pisem [Complete works and letters]. In 20 vols. Vol. 2. Moscow: Nauka Publ., 2000. 395 p. (in Russian).

10. Koptelova T. I. Muzyka kak otrazhenie zhizni: organicheskaya metodologiya izucheniya muzykal'nogo iskusstva [Music as Reflection of Life: Organic Methodology of Studying of Musical Art]. Vestnik kafedry UNESCO "Muzykal'noe iskusstvo i obrazovanie" - Bulletin of the UNESCO Chair "Musical Arts and Education", 2016, no. 3 (15), pp. 13-20 (in Russian, abstract in English).

11. Koptelova T. I. Muzykal'naya estetika XXI veka v paradigme organicheskoj filosofii [A musical esthetics of the 21 st century in a paradigm of organic philosophy]. Filosofskaya mysl', 2017, no. 9, pp. 101-114 (in Russian, abstract in English).

12. Asaf'ev B. V. Putevoditel' po kontsertam [Guide to concerts]. 2nd ed. Moscow: Sovetskij kompozitor Publ., 1978. 200 p. (in Russian).

13. Koptelova T. I. Kommertsiya protiv iskusstva: teatral'no-estradnoe shou v mekhanisticheskoj i organicheskoj filosofskikh paradigmakh [Commerce against art: a theatrical and variety show in mechanistic and organic philosophical paradigms]. Filosofiya khozyajstva. Al'manakh Tsentra obshchestvennykh nauk i ekonomicheskogo fakul'teta MGU imeni M. V. Lomonosova, 2018, no. 2 (116), pp. 39-48 (in Russian, abstract in English).

14. Kholopov Yu. N. Novye paradigmy muzykal'noj estetiki XX veka [New paradigms of a musical esthetics of the 20th century]. Estetika na perelome kul'turnykh traditsij. Moscow: IF RAN Publ., 2002, pp. 132-147 (in Russian). 
15. Florovskij G. Vostochnye Ottsy Tserkvi [East Priests of Church]. Moscow: AST Publ., 2003. 633 p. (in Russian).

16. Aspect A. Teorema Bella: naivnyj vzglyad eksperimentatora [Theorem Bella: an innocent look of the experimenter]. Translated from English. by P. V. Putenikhin. 2007. Available at: http:/quantmagic.narod.ru/volumes/VOL422007/p2135.html (accessed: 23 May 2018) (in Russian).

17. Aristotle. Metafizika [Metafizika]. Translated from Greek by P. D. Pervov and V. V. Rozanov. Moscow: Institut filosofii, teologii i istorii sv. Fomy Publ., 2006. 232 p. (in Russian).

18. Koptelova T. I. Teatral'no-estradnoe shou v paradigme organicheskoj filosofii (na primere shou "Igra" Nikolaya Baskova) [A theatrical and variety show in a paradigm of organic philosophy (on the example of the show "Game" of Nikolay Baskov]. Nauka. Mysl', 2017, no. 4, pp. 96-103 (in Russian, abstract in English).

19. Asmus V. F. Platon [Plato]. Moscow: Mysl' Publ., 1969. 242 p. (in Russian).

20. Il'in I. A. Osnovy khristianskoj kul'tury [Bases of Christian culture]. Available at: http://rusk.com. ru/lib/ prav/iljin-osnov y_kultury.html (accessed: 23 May 2018) (in Russian).

21. Popov V. S. Russkaya shkola dukhovogo ispolnitel'stva [The Russian School of Wind Performing]. Vestnik kafedry UNESCO "Muzykal'noe iskusstvo i obrazovanie" - Bulletin of the UNESCO Chair “Musical Arts and Education”, 2017, no. 3 (19), pp. 123-132 (in Russian, abstract in English).

22. Mae-Wan Ho, Saunders P. Beyond Neo-Darwinism: an Introduction to the New Evolutionary Paradigm. London: Academic Press, 1984. 376 p.

Submitted 07.06.2018; revised 27.02.2019.

About the author:

Tatyana I. Koptelova, Associate Professor at the Department of Philosophy, Sociology and Political Science, Nizhny Novgorod State Agricultural Academy (Gagarin Ave, 97, Nizhny Novgorod, Russian Federation, 603107), PhD (Philosophy), Associate Professor, koptelova2210@rambler.ru

The author has read and approved the final manuscript. 


\title{
ПРАКТИКО-ОРИЕНТИРОВАННЫЕ СТРАТЕГИИ ПОГРУЖЕНИЯ УЧАЩИХСЯ В ХУДОЖЕСТВЕННЫЙ МИР МУЗЫКАЛЬНЫХ ПРОИЗВЕДЕНИЙ
}

\author{
В. П. Рева,
}

Могилёвский государственный университет имени А. А. Кулешова, г. Могилёв, Республика Беларусь, 212022

Аннотация. Восприятие музыки представляет многоуровневую систему творческой деятельности, осуществляелой в единстве элоциональных и рациональных, коллективных и индивидуальных, телесных и духовных, осознаваельх и интуитивных, линейных и нелинейных механизлов и операиий. Воспринилая музыку, человек познаёт не только содержание, но и салого себя, реализует личностные духовнье потенииальь. В статье получили обоснование и эксперилентальную апробацию практико-ориентированные стратегии погружения в художественный мир музыкальньх произведений: интонаиионно-пластическая, интонаиионно-жанровая, интонационно-созериательная, интонационно-стилевая. Охватываюшие широкую область содержания музыкального искусства, они открыты к дополнениял, совершенствованию, расслатриваются как базовыле основы воспитания музыкального восприятия, которые могут использоваться выпускникали школ в постобразовательный период жизни. Ни в одной из апробированных эксперилентальных ситуаций не давалось прялых указаний о тол, что конкретно необходило услышать в лузыкальнол произведении. Превалировали приёль ненавязчивого наведения внилания на интонационное раскрытие музыкального содержания, проецирования его на жизненный опьт учащихся (речевой, телесный, кинестетический, солатический, пластический, жестовый). Несопоставильєе результаты восприятия возникают в ситуациях предлетно-зрительного и элоционально-образного раскрытия содержания музыки, пересказа его педагогол или установления связей с интонационныли опытол учашихся (прообразали речи, телесньлии движенияли), при отстранённол слушании музыки и активнол переживании, погружении в элоционально насыщенный мир музыкальных образов. Попьттки приблизиться $\kappa$ содержанию, минуя духовно-телесный уровень восприятия, не приводят $\kappa$ сколько-нибудь значилыли педагогическил результатал.

Ключевые слова: музыкальное воспитание, интонация, музыкальное восприятие, переживание, погружение, стратегия, художественный образ. 
Благодарности: Автор выражает признательность учителям музыки средней школь № 43 г. Могилёва за участие в апробаиии представленного в статье педагогического подхода.

Для цитирования: Рева В. П. Практико-ориентированные стратегии погружения учащихся в художественный мир музыкальных произведений // Музыкальное искусство и образование. 2019. Т. 7. № 1. С. 25-39.

\title{
PRACTICE-ORIENTED STRATEGIES OF STUDENT IMMERSION IN THE ARTISTIC WORLD OF MUSICAL COMPOSITIONS
}

\section{Valentin P. Reva,}

Mogilev State University named after A. A. Kuleshov, Mogilev, Republic Belarus, 212022

\begin{abstract}
Music perception is a multi-level system of creative activity carried out in a unity of emotional and rational, collective and individual, physical and spiritual, conscious and intuitive, linear and non-linear mechanisms and actions. When a person perceives music, he cognizes not only the content, but also himself, realizes personal potential. In the article practice-oriented strategies for immersion into the artistic world of musical works: intonational-plastic, intonational-genre, intonational-contemplative, intonational-stylistic were grounded and experimentally tested. Covering a wide area of music content, they can be added, improved are considered as the basic foundations of the education of music perception, on which students can rely in their lives. None of the stated approaches gave direct instructions on what specifically needs to be heard in a piece of music. The methods of unobtrusive targeting of attention to the disclosure of musical content, its projection on life experience (speech, physical, kinesthetic, somatic, plastic, gestural) were prevailed. Incomparable results of perception arise in situations of subject-visual or emotional-figurative disclosure of the content of music, retelling it by a teacher or establishing links with students' intonation experience (prototypes of speech, bodily movements); while listening to music, or its active experience, suspended, immersed in the emotionally saturated world of musical images. Attempts to overcome the spiritual and physical level of perception, to approach the content of music, bypassing these processes, do not lead to any meaningful pedagogical results.
\end{abstract}

Keywords: musical education, intonation, music perception, experience, immersion, strategy, artistic image. 
Acknowledgements: The author expresses his gratitude to the music teachers of Mogilev secondary school No. 43 for participating in approbation of the presented in the article pedagogical approach.

For citation: Reva V. P. Practice-oriented strategies of student immersion in the artistic world of musical compositions. Muzykal'noe iskusstvo $i$ obrazovanie = Musical Art and Education, 2019, vol. 7, no. 1, pp. 25-39.

\section{«Педагогическая стратегия» как категория педагогики музыкального образования}

В категориальном ряду теории музыкального восприятия (методов, принципов, механизмов, операций) отдельное место занимает категория «стратегия». Её универсальность состоит в целеполагании деятельности как педагогов, так и учащихся. Методы определяют технологические процессы; принципы - правила, которыми руководствуется человек; механизмы и операции - взаимосвязанные и последовательные действия. Педагогические стратегии характеризуют перспективные линии воспитания, обучения и развития учащихся, самовоспитания, применения полученных знаний, умений и навыков в практической деятельности. Можно сказать, что сущность методов, принципов, механизмов и операций состоит в формировании практико-ориентированных стратегий действий, применительно к восприятию музыки погружения в интонационно насыщенный мир художественных образов, сопереживания им.

В педагогике искусства наблюдается зауженное понимание методов музыкального восприятия. Его ракурсы, как и сам человек, постоянно меняются, зависят от его онтогенетического развития, знаний, жизненно- го опыта. Невозможно сформировать универсальные методы восприятия песен, картин живописи, спектаклей, кинофильмов, симфоний, балетов, литературных произведений. Можно говорить лишь о перспективах приближения к их содержанию, соизмерения с духовными потребностями зрителей, читателей, слушателей, то есть о стратегиях действий. Чем большим количеством практико-ориентированных стратегий обладает реципиент искусства, тем он свободнее в выборе средств, знаний, информации, резервов психики, жизненного опыта, необходимых для погружения в образный мир и его контекстуального окружения.

Музыкальное восприятие является одной из форм коммуникации, взаимодействия слушателя с художественными образами как «вторичной действительностью», запечатлённой в содержании музыки переживаний и настроений человека. Избирательно-коммуникативная составляющая музыкального восприятия обретает особое художественное наполнение тогда, когда в содержании музыки обнаруживаются чувства, созвучные жизненному опыту слушателя, резонирующие с его духовной сферой. Этими фракторами определяется успешность овладения практико-ориентированными стратегиями погружения в интонационно-насыщенный 
мир музыкальных образов, задействования духовно-телесных ресурсов, средств и форм творческой деятельности, наслаждения музыкой как ключевых ценностно-образующих смыслов диалогов с искусством.

В числе стимулов, побуждающих к погружению в художественный мир музыки, - глубина эмоциональных откликов, полученных музыкальных впечатлений, интересов и переживаний человека. Эмоциональные отклики становятся предпосылками погружения в тех случаях, когда синхронизируются с личностно ориентированными установками слушателя, духовными потребностями, его творческой активностью. Вне этих действий переосмысление образного материала, средств художественной выразительности, переведение их в эстетическую плоскость невозможны по определению.

С участием ассоциативного мышления восприятие музыки обретает коммуникативную завершённость, переинтонирование содержания на язык пластики, мимики, жестов, выразительных движений, мысленных диалогов с воображаемыми героями и персонажами художественного мира музыкальных произведений. Психолого-диалектическая сущность таких процессов объясняется тем, что «художественное произведение и его воздействие на человека может быть осмысленным только при условии выхода за пределы текста к автору и ценителю его творения. Произведение искусства не самоцель, оно - средство реализации другой цели, а именно - психологического воздействия на личность» [1, с. 4].

На психологическол уровне погружение в содержание музыки обу- словлено познавательными установками, настройками на интонационную волну, заражением эмоциями, аналогичными воздействию увлекательной книги, захватывающего сюжета театрального спектакля, требующими временного отвлечения от собственного «Я», подчинения чувствам, переданным в произведении искусства. Погрузиться в искусствозначит увлечься его содержанием, побыть некоторое время в мире франтазии, художественного вымысла, сюжета, чувств и мыслей другого человека. Выходы из погружения сопровождаются ощущениями духовного обновления, внутреннего возвышения, открытия новых жизненных перспектив, нацеленности на успех в созидательной деятельности.

Умением погружаться в образный мир музыки определяется культура музыкального восприятия человека. Этому, так же как чувству любви, нравственному соучастию, невозможно научить, используя однолинейные дидактические подходы и алгоритмы обучения. Такие эмоциональные состояния возникают спонтанно, неожиданно, непрогнозируемо или, используя терминологию синергетики, непреднамеренно, хаотично. И в то же время закономерно, не случайно. Их предваряет долгий подготовительный период накопления опыта восприятия, запечатления в тайниках психики ярких художественных событий, чтобы однажды выплеснуться наружу неожиданными откровениями, порывами чувств, ощущениями личной причастности $к$ искусству. Понять и должным образом интерпретировать такие процессы можно только через обновлённую парадигму восприя- 
тия, синергетически, как самоорганизацию духовных состояний, самовыражение энергий чувств и переживаний человека.

Вводя учащихся в художественный мир музыкального искусства, важно выделить те ключевые точки интонационной палитры, которые могут плодоносить в образном мышлении творческими открытиями, эвристическими находками, поисками личностных смыслов. Такой прогноз на достраивание восприятия определяет логику построения самого педагогического процесса, не противоречит классическим педагогическим воззрениям на воспитание как побуждение к самовоспитанию, самоорганизации духовных состояний.

Погружение в художественный мир музыки - активный процесс, основанный на франтазии и творческом воображении, без которого, как уже говорилось, переосмысление образного языка музыки, переведение его в художественно-эстетическую плоскость невозможно.

Только в условиях творческой переработки интонационного материала музыкальное восприятие обретает коммуникативную завершённость, поддаётся переводу на язык пластики, мимики, жестов, выразительных музыкальных движений, мысленных диалогов с воображаемыми героями и персонажами художественного мира музыки, многочисленных других средств перевоплощения субъектноличностного характера.

Ранее нами указывалось: «В отличие от инсценировок, осуществляемых в форме свободного выражения эмоций, погружение в образный мир музыки обусловлено логикой развёртывания художественного содержа- ния. Погрузиться - значит совпасть с эмоциональной волной, несомой музыкой, проникнуться её энергетикой, перевоплотиться в образ персонажа, лирического героя, внутренне воссоздать эстетическую программу восприятия, заложенную в музыкальном произведении, переосмыслить её в соответствии с собственным жизненным опытом» [2, с. 32].

Умение входить в такие состояния требует систематических упражнений, аналогичных работе актёра над ролью, по развитию управления собой. На основе саморегуляции восприятия актуализируется воспитывающая фрункция искусства, закладываются практико-ориентированные стратегии музыкального восприятия.

На технологическом уровне погружение в образный мир музыки включает фразы вживания, отождествления, соучастия, перевоплощения, переживания, сопереживания непосредственного погружения, выхода из него, установления связей с ситуативными жизненными контекстами. Каждая из них характеризует определённую степень сотворчества, необходимого для полноценного восприятия музыки. Выбор форм погружения зависит от типов музыкального содержания (лирики, драмы, эпоса), жанров, стилей. Общими остаются сосредоточенность на содержании музыки, нацеленность на переживания, без которых художественный мир музыки непроницаем для восприятия как эмоционально-образного познания жизни, красоты выражения в музыке человека.

Уровни погружения зависят от возраста слушателей. Для младших школьников характерны игровые 
формы вживания в образный мир, отождествления себя с действующими героями и персонажами музыкального произведения; для подростков - соучастия в действиях, самоанализ возникающих чувств, для школьников старшего возраста - переживание художественного образа, сопереживание самому себе, собственному «Я», для взрослого человека (интеллектуала) - фрилософрскоэстетические прозрения. Точных градаций не существует, их трудно обозначить даже на теоретическом уровне, в чём, собственно говоря, нет необходимости. Важно установить духовно-личностный контакт с музыкальным искусством. Всё остальное становится непреложной данностью восприятия.

Перспективными с точки зрения воспитания музыкального восприятия являются взаимообусловленные интонационно-пластическая, интонационно-жанровая, интонационно-созерцательная и интонационностилевая стратегии погружения в художественный мир музыкальных произведений.

\section{Интонационно-пластическая стратегия}

Для характеристики интонационно-пластической стратегии обратимся к прелюдии Клода Дебюсси «Шаги на снегу» (тетрадь 1, № 6). $\mathrm{C}$ целью погружения учащихся в художественный образ данного произведения в содержание занятий были включены следующие проблемно-поисковые задания:

а) выделение одномоментного интонационного образа восприятия;

б) анализ интервалов малой и большой секунды; в) стимулирование ассоциативного поля восприятия;

г) выявление жанровой характеристичности содержания;

д) духовно-телесные проекции художественного образа.

Одномоментный образ пьесы может быть обозначен тремя протоинтонационными характеристиками, отражающими многозначность смысловых оттенков, переданных в музыке, рассеянности звуковых образов в пространстве, утончённого психологизма, телесной готовности к проявлению:

- осторожности,

- духовной чуткости,

- любопытства.

Вхождение в образный мир музыкального произведения, созданный франтазией композитора, открывает широкие возможности для достраивания субъективных образов восприятия как хрупких, вкрадчивых, осторожных движений, сопровождающихся сдержанным дыханием, мимикой, жестами.

Большое подкрепляющее значение в раскрытии образного содержания на наших занятиях приобретали используемые в работе художественные контексты, в частности репродукции картин Клода Моне «Мороз» и «Сорока». По какому снегу - пушистому или заледенелому, «с корочкой», - мог передвигаться человек? Имитировались шаги, словно проваливающиеся сквозь покрывавшую снег ледяную поверхность («скрипящая секунда»), в медленном темпе, техникой «переката с носка на пятку». Подобные «прощупывания» движений создавали эффект интонационного погружения, соучастия, моделирования, переданных в музыке психологических состояний: насто- 


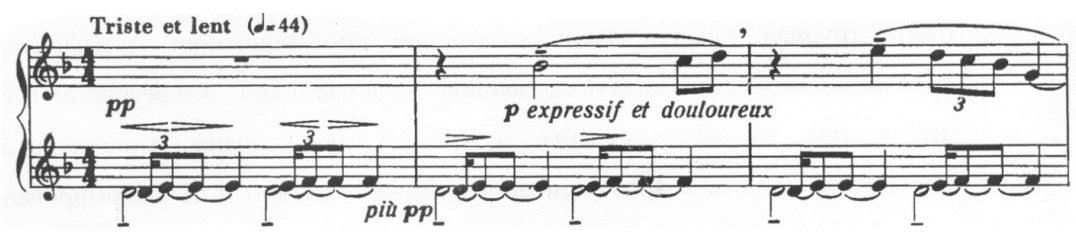

роженности, любопытства, удивления (пример 1).

Каждое из таких определений обогащало общую панораму музыкального восприятия, наполняло его образно-символическими смыслами, интонационно-телесным переосмыслением содержания, подготавливало базу для эстетически и мускульноосязательного переживания. Пластические движения (рук, мимики, пантомимики) исполнялись в соответствии с динамической шкалой звучания (телесная субстаниия восприятия). Внимание учащихся обращалось на изменения направлений мелодии в верхнем голосе, оттенков чувств (духовная составляюшая восприятия). Собранные в единый пластический образ, эти действия рассматривались как форма выражения многомерного чувства человека, переданного в музыке.

Логическим завершением анализа, его кульминационной точкой стал разбор заключительного аккорда пьесы, синтезирующего в себе слуховые и двигательные ассоциации в одновременности, запечатле- вающего красоту мгновения, отстранённости от того, к чему невозможно прикоснуться руками, но вполне допустимо чувствами. Эти состояния получали отражение в мимике (в мускульно-осязательных ощущениях) и затаённой восторженности (духовного начала), того и другого в одновременности (пример 2).

Сказанное позволяет констатировать, что перспективы погружения в образное содержание возникают в ситуациях интонационно-пластического моделирования уже на начальных этапах восприятия, зарождения интереса к музыке, обнаружения в её содержании личностных смыслов на уровне обобщения эмоций, чувств, переживаний. В музыкальных произведениях, написанных гениальными композиторами, эти стороны содержания раскрываются предельно рельефно, неся в себе реминисценции детства, грёзы, франтазии, полёты мыслей как строительный материал музыкального восприятия, осознания личной причастности к искусству. Дефицит знаний теории музыки, специальной

Пример 2

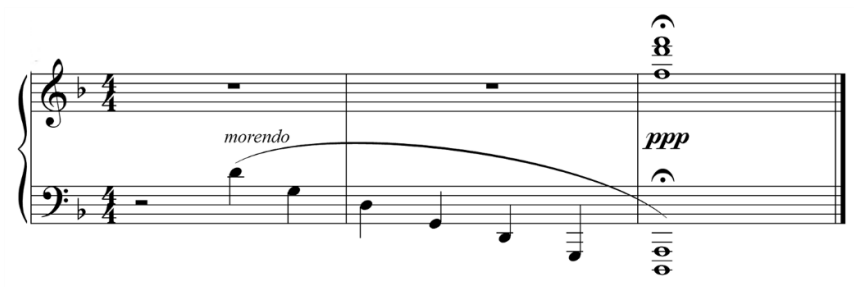


терминологии компенсируется активностью творческого воображения и художественной франтазии слушателей.

Педагогическими условиями для подготовки учащихся к погружению в образный мир музыки являются: доскональное знание учителем текста музыкального произведения как единственно объективного источника информации для принятия методических решений; владение техниками интонационного анализа музыки; установление педагогического общения с учащимися с учётом их жизненного опыта, интересов. Навыки погружения в образное содержание закрепляются в личностном фонде культуры музыкального восприятия в тех случаях, когда опираются на внутреннюю восприимчивость музыки, не навязываются извне, получают подкрепление в интонационном опыте учащихся.

Операционные элементы интонационно-пластической стратегии музыкального восприятия включают: установление связей с жизненными прообразами, осознанность пластических решений; персонификацию художественных образов (персонаж, лирический герой); театрализацию и сценичность игровых действий; знакомство с музыкальной формой (прологом, кульминациями, средствами выразительности). Установки на погружение в художественный мир музыкального произведения закрепляются в опыте восприятия музыки тогда, когда не навязываются извне, становятся внутренними стимулами: потребностью, стилем и формой музыкального восприятия.

\section{Интонационно-жанровая стратегия}

Музыкальное искусство характеризуется многообразием жанров, историко-художественное возникновение которых обусловлено необходимостью отражения социально значимых ситуащий жизни, не обязательно связанных с предметной практикой человека. Жанровая ориентация восприятия облегчает установление связей музыкального содержания с жизненным опытом учащихся. Вне понимания жанровых особенностей музыки глубина проникновения в её содержание будет значительно меньшей или вовсе недоступной для восприятия. Жанровые ассоциации связывают жизненный опыт слушателей с художественными впечатлениями прошлого. Стратегии погружения в восприятие строились по жанровым признакам - от освоения бытовых сторон жизни в песнях, танцах, маршах до более сложных жанровых обобщений, прежде всего в музыкальных произведениях, написанных для детей, а также в произведениях инструментальной музыки (прелюдиях, ноктюрнах, увертюрах).

Жанровое содержание становится личностно значимым для слушателя тогда, когда получает эстетическое переосмысление, увязывается с красотой звукового отражения жизни, выполняет функцию порождающей модели восприятия. Предметный уровень музыкального восприятия локален и однозначен, в то время как интонационноэстетический - полиморфичен и многоканален, включает не только слышание звука, но и переживание, осмысление, достраивание. Восприятие 
музыки основано на констатации жанровых значений во всём многообразии их интонационно-образных проявлений. Привнесения даже незначительного жанрово-ассоциативного намёка достаточно для того, чтобы процесс восприятия изменил свой смысловой ракурс, получил обновлённую художественную определённость.

Проиллюстрируем сказанное на примере восприятия Ноктюрна Ф. Шопена Ми-бемоль мажор, соч. 9 № 2. В музыковедческой литературе отмечается его светлый, созерцательный характер, утверждающий внутреннюю гармонию чувств человека [3, c. 324]. Интонационная характеристичность содержания близка интонациям речевого повествовательного высказывания, окрашенного оттенками элегических размышлений, и может быть определена как нежная, мечтательная, задулчивая. Комплекс основных средств жанровой выразительности включает негромкую динамику, умеренный темп, прозрачность фрактуры, волновой характер мелодического развития. В интонационной структуре произ-

ведения можно выделить два типа интонационных образов-эталонов: светлую повествовательную интонацию начальных фрраз ноктюрна, включающую мелодический ход от V к III ступени (лирическая секста), придающий особую мягкость и напевность звучанию (пример 3), и нежную, мечтательную интонацию шестого такта, имеющую достаточно устойчивые прообразы в речевой практике для выражения таких признаков чувства, как задушевность, мягкость, затаённость (пример 4).

На анализе именно этих интонаций целесообразно заострить внимание учащихся. Воплощение их в музыке имеет свою специфику, являясь не точной записью речи, не прямым отражением речевых интонаций, а только ассоциативно близким им. Так, например, графически интонационный профиль мечтательной интонации шестого такта ноктюрна можно представить в виде рис. 1.

В обобщающей интонации ноктюрна могут быть выделены широкий характер мелодии, неторопливый темп, размеренный тип дыхания, имеющие

Пример 3

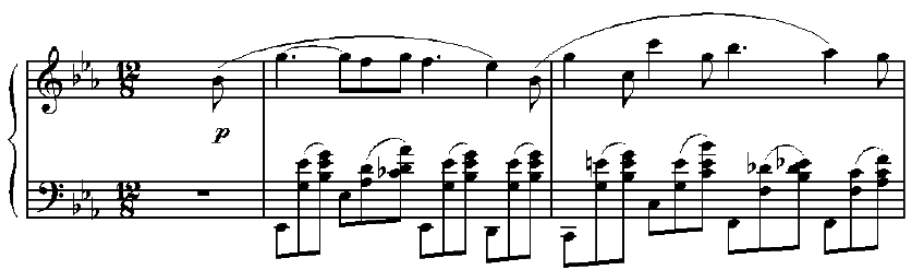

Пример 4

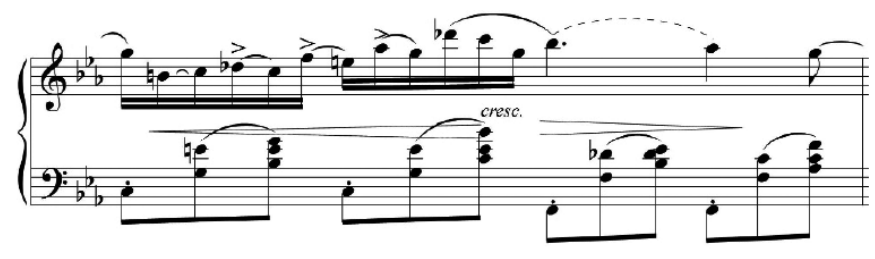




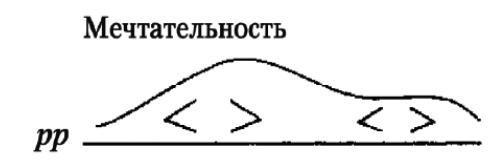

Рис. 1. Интонационный профиль мечтательной интонации шестого такта ноктюрна

устойчивые прообразы в речи человека, соответствующим образом закреплённые в его речевой практике. Осознание жанровых особенностей музыки помогает детям понять мотивы использования композитором именно такой системы выразительных средств, формы, логики композиционных решений. Характеристика интонации лирического героя основывается не на произвольном подборе образно-поэтических сравнений, а на логике, вытекающей из самого содержания музыки, анализа выраженного в ней интонащионного образа, лежащего в его основе жизненного процесса.

При обосновании жанровой стратегии погружения в художественный мир музыкальных произведений необходимо учитывать проясняющие функции жанра в установлении связи содержания и формы, коренных жанровых основ (песни, танца и марша), вокальной, инструментальной и танцевальной музыки. Жанровые стратегии погружения в образное содержание способствуют осознанному освоению художественного пространства музыки, сокращению внемузыкальных ассоциаций, переориентации музыкального восприятия с репродуктивных форм на творческие.

\section{Интонационно-созерцательная стратегия}

Созерцание как форма чувственного познания (наблюдения, размышле- ния, самоуглубления) связано с установлением универсальных связей с миром и жизнью человека [4, с. 323]. Применительно к восприятию музыки - удовлетворения потребностей в самоактуализации, наслаждении, погружении в музыкальное искусство, медитации, растворении в художественных событиях. Созерцание - один из качественных критериев восприятия музыки, раскрытия её жанров, связанных с медитациями (грёзы, пасторали, размышления, элегии, колыбельные песни), чувственными состояниями человека, глубокими переживаниями. В. В. Медушевский отмечает: «Созерцание явлений мира не безучастно, его скрытую интонацию характеризуют определённый темп и ритм, градации и изменения напряжённости - расслабленности, светлая или тёмная темброгармоническая окраска» [5, с. 68]. Образцами таких типов музыкального содержания наполнена музыка для детей, написанная отечественными и зарубежными композиторами-классиками - М. П. Мусоргским, П. И. Чайковским, С. С. Прокофььевым, Г. В. Свиридовым, Э. Григом, Р. Шуманом и др.

Эфрдективной для погружения в образный мир музыки является метафоризация содержания, позволяющая устанавливать аналогии с жизненным опытом учащихся (интонационно-речевым, телесным, кинестетическим, эмоционально-чувственным и др.). В качестве примера сравним результаты структурного и метафрорического восприятия и анализа пьесы П. И. Чайковского «Песня жаворонка», соч. 39 № 22 (рис. 2).

Как можно заметить, структурное восприятие, ограничиваясь констатацией звукового материала безотноси- 


\section{Структурное восприятие}

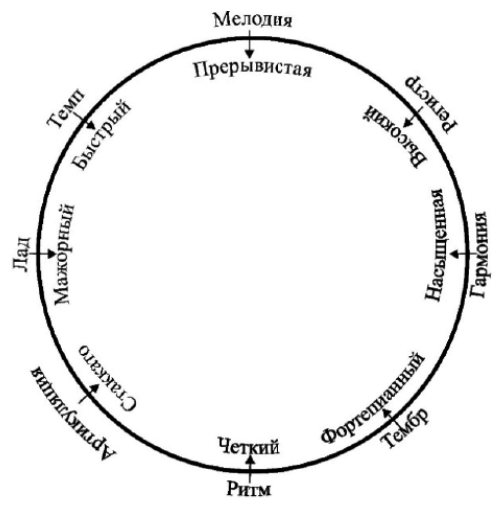

\section{Метафорическое восприятие}

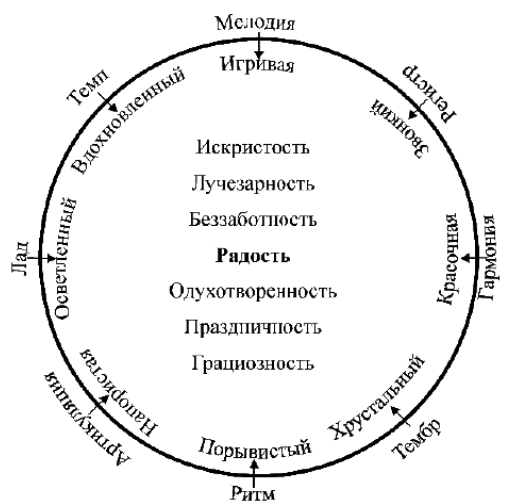

Рис. 2. Результаты восприятия и анализа пьесы П. И. Чайковского «Песня жаворонка»

тельно к содержанию (быстрого или медленного, громкого или тихого, мажорного или минорного, плавного или отрывистого звучания), не ведёт к погружению в содержание. Метафорическое восприятие связано с художественно-ассоциативным переосмыслением музыки как самовыражения человека, наслаждающегося пением птицы. Между этими стилями восприятия музыки пролегает непреодолимая дистанция с точки зрения достижения цели музыкального восприятия как чувственного познания искусства.

\section{Интонационно-стилевая стратегия}

Стиль, наряду с языком музыки, жанрами, представляет одну из важнейших составляющих образной системы музыкального искусства художественными формами. Распознание музыкально-стилевых особенностей лежит в основе слуховой диффреренциации музыки, индивидуальных стилей композиторов, исторических эпох, народной музыки, национальных композиторских школ и направлений.
Различают три основные фрункции музыкального стиля:

- историко-культурную,

- смысловую,

- творческую.

О необходимости формирования чувства музыкального стиля, умений определять по слуху незнакомых авторов писал Д. Б. Кабалевский: «Слуховой опыт... даёт вполне достаточную основу для того, чтобы подвести учащихся к ощущению стиля того или иного композитора, выработать в них способность определять автора по новой, ранее ещё не слышанной ими музыке» [7, с. 129].

Рассмотрим формирование стилевой стратегии погружения в образный мир музыки на примере восприятия пьесы В. И. Ребикова «Дервиш», соч. 29 № 15. По признанию современников композитора, в её содержании получил воплощение образ странствующего мусульманского монаха. Восточными интонациями наполнено звучание музыкального произведения. Можно сказать, что в его крайних разделах рассказывается о самом лирическом герое, ша- 
гах - то приближающихся, то удаляющихся, словно бы замирающих вдали (пример 5).

Средняя часть ассоциируется с пластикой, движениями, реминисценциями жизни, воспоминаниями о каких-либо событиях. Фразировка, мелодия, её ритмический рисунок ассоциативно связаны с пантомимой, пластическими формами раскрытия образа, изысканными манерами, игровыми нюансами (пример 6).

Об этом можно судить, учитывая, что экспериментирование с образным материалом было свойственно творческому кредо композитора, его индивидуальному авторскому стилю, в частности в инструментальных миниатюрах, связанных с выражением оттенков разговорной речи, мелопластики, меломимики, ритмодекламации, утончённых духовных и телесных проявлений, движений [8].

В процессе әкспериментальной работы мы исходили из того, что стилевые особенности музыки одного автора получают более рельефное восприятие на фоне стилей других композиторов. В рассматриваемой педагогической ситуации ффункцию контрастирующего произведения выпол- няла пьеса Л. Бетховена «Сурок», соч. 52 № 7.

Целесообразность сравнения сочинений этих композиторов заключалась в сопоставлении образных палитр произведений программной музыки, интонаций, связанных с выражением разных социальных статусов лирических героев (см. таблицу).

\section{Сравнительный анализ восприятия музыки разных композиторских стилей}

В отличие от традиционных подходов к организации музыкального восприятия поисково-творческие задания озвучивались не перед началом прослушивания, а после него. Целеполагание такого подхода заключалось в подготовке детей к обнаружению контрастных эмоциональных наклонений музыки непосредственно по фракту звучания, влияний программных установок, отражаемых в названиях пьес, выделении комплексов выразительных средств, используемых композиторами, мотивации выбора жанров музыкальных произведений, необходимых для реализации художественных замыслов.

Пример 5

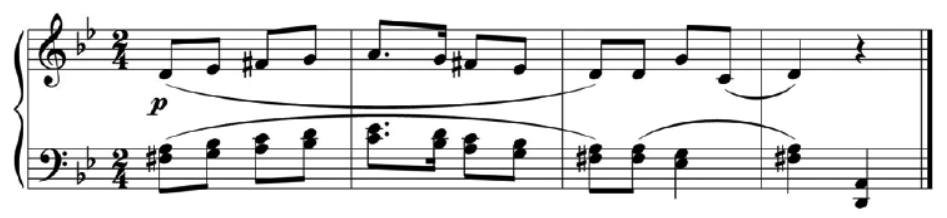

Пример 6

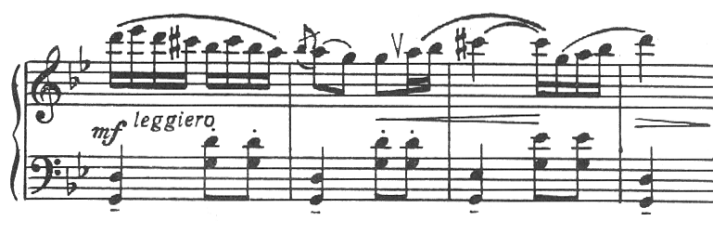




\section{Сопоставление образных палитр произведений программной музыки}

\begin{tabular}{|l|l|}
\hline \multicolumn{1}{|c|}{ В. Ребиков «Дервиш» } & \multicolumn{1}{c|}{ Л. Бетховен “Сурок» } \\
Содержание пьесы наполнено жанровыми & \multicolumn{1}{c|}{ Ровная, нейтральная в эмоциональном } \\
признаками песенности и танцевальности, & отношении мелодия, неторопливый темп, \\
утончёнными интонациями & минор придают повествованию оттенок \\
повествования, изысканности поведения, & будничности, обыденности. Значительная \\
душевных переживаний. Восточный & часть жизни бродячего музыканта \\
колорит музыкальной речи придают & позади. Вместе с тем в интонации \\
используемый композитором медленный & просвечивают жизненные воспоминания, \\
темп, гармонический минор, особенности & как бы приоткрывающие внутренний мир \\
построения музыкальных фраз. В средней & лирического героя пьесы, его отношение \\
части превалируют интонации танца, & к персонажу (сурок), проявляющееся \\
хореографического развития образа. & в звуковых характеристиках, украшениях \\
Остановки в З6, 38, 40 и 42 тактах & мелодии мелизмами, мягком звучании \\
ассоциируются с селями-приветствиями, & терций, просветлении лада. Сдержанная \\
реверансами, (крутящимися» & строгость, затаённая внутренняя \\
дервишами). Эти характеристики присущи & энергия - типичные черты \\
авторскому стилю В. Ребикова, его & индивидуального авторского стиля - \\
авторскому кредо - «Многое в малом». & ощутимо проявляются даже в таком \\
Лирический герой - зритель или участник & небольшом сочинении композитора. \\
некоего культа. & Лирический герой - бродячий музыкант. \\
\hline
\end{tabular}

Формирование стилевых стратегий музыкального восприятия основано на сопоставлении: контрастных по содержанию музыкальных произведений разных авторов; музыки разных народов мира; использовании историко-культурной информации, отражающей мотивы творческих замыслов; автобиографических сведений из жизни композиторов; впечатлений детства. Большое значение приобретает умение выделять и анализировать интонационное своеобразие индивидуальных авторских стилей как мироощущений композиторов, обнаруживать в музыке тождества и контрасты, окружать восприятие адекватными художественными контекстами.

Знакомство со стилевыми особенностями музыки сопрягается с анализом её языка, решением обучающих задач. В многочисленных ситуациях музыкального восприятия сти- левая стратегия оказывается единственно возможным средством достижения осмысленных наблюдений за развитием содержания. Владение практико-ориентированными стратегиями погружения в образный мир музыки является показателем культуры музыкального восприятия, художественно-педагогической эфрективности.

\section{Заключение}

Музыкальное восприятие - одна из форм коммуникации, взаимодействия слушателя с художественными образами как «вторичной действительностью», запечатлёнными в содержании музыки: чувств, переживаний и настроений человека. Избирательно-коммуникативная составляющая музыкального восприятия обретает особое художественное наполнение тогда, когда обнаруживаются чувства, созвучные жизненному опы- 
ту слушателя, резонирующие с его духовной сферой. В числе важнейших стимулов, побуждающих к погружению в художественный мир музыки, - эмоциональные отклики, музыкальные впечатления, интересы и переживания слушателя. Ими определяется успешность овладения практико-ориентированными стратегиями погружения в интонационно насыщенный мир музыкальных образов, задействования духовно-телесных ресурсов, средств и форм творческой деятельности, наслаждения музыкой как ключевых, цен- ностно-образующих смыслов диалогов с искусством.

Музыкальные переживания не возникают спонтанно, являясь результатом кропотливой творческой работы слушателя, симбиоза художественной фантазии и воссоздающего воображения, образующих созидательное поле восприятия и анализа музыки. Установление плодотворного общения с музыкой немыслимо без интонационно-телесного сопереживания, вне которого невозможно достичь сколько-нибудь значимых воспитательных результатов.

\section{БИБЛИОГРАФИЯ}

1. Крупник Е. П. Психологическое воздействие искусства. М.: Изд-во Института психологии, 1999. $240 \mathrm{c}$.

2. Рева В. П. Интонационное погружение как индивидуальная слушательская стратегия эстетического восприятия музыки // Вестник кафедры ЮНЕСКО «Музыкальное искусство и образование». 2014. № 2 (6). С. 28-40.

3. Соловиов А. А. Фридерик Шопен. Жизнь и творчество. М.: Музгиз, 1969. 504 с.

4. Эстетика: словарь / под общ. ред. А. А. Беляева [и др.]. М.: Политиздат, 1989. 447 с.

5. Медушевский В. В. Интонационная форма музыки. М.: Композитор, 1993. 262 с.

6. Дарвин Ч. О выражении эмоций у человека и животных / Ч. Дарвин, П. Экман. СПб.: Питер, $2001.384 \mathrm{c}$.

7. Кабалевский Д. Б. Основные принципы и методы программы по музыке для общеобразовательной школы // Музыка. 1-3 классы. М.: Просвещение, 1988. С. 1-32.

8. Логинова В. A. О музыкальной композиции начала XX века: к проблеме авторского стиля В. Ребикова, Н. Черепнина, А. Станчинского: автореф. дис. ... канд. искусствоведения: 17.00.02. М., 2002. 22 c.

Поступила 02.03.2019; принята к публикаиии 15.03.2019.

Об ав торе:

Рева Валентин Павлович, доцент кафедры музыки и эстетического образования Могилёвского государственного университета имени А. А. Кулешова (ул. Космонавтов, 1, г. Могилёв, Республика Беларусь, 212022), кандидат педагогических наук, доцент, val.r2014@mail.ru

Авторол прочитан и одобрен окончательный вариант рукописи. 


\section{REFERENCES}

1. Krupnik E. P. Psikhologicheskoe vozdejstvie iskusstva [Psychological impact of art]. Moscow: Institut psikhologii Publ., 1999. 240 p. (in Russian).

2. Reva V. P. Intonatsionnoe pogruzhenie kak individual'naya slushatel'skaya strategiya esteticheskogo vospriyatiya muzyki [Intonation immersion as an individual listening strategy of aesthetic perception of music]. Vestnik kafedry UNESCO "Muzykal'noe iskusstvo i obrazovanie" = Bulletin of the UNESCO Chair "Musical Arts and Education”, 2014, no. 2 (6), pp. 28-40 (in Russian, abstract in English).

3. Solovtsov A. A. Frederik Shopen. Zhizn'i tvorchestvo [Frederic Chopin. Life and creativity]. Moscow: Muzgiz Publ., 1969. 504 p. (in Russian).

4. Estetika: slovar' [Aesthetics: dictionary]. Under general editorship of A. A. Belyaev [et al.]. Moscow: Politizdat Publ., 1989. 447 p. (in Russian).

5. Medushevsky V. V. Intonatsionnaya forma muzyki [Intonation form of music]. Moscow: Kompozitor Publ., 1993. 262 p. (in Russian).

6. Darwin C. O vyrazhenii emotsij u cheloveka i zhivotnykh [The expression of the emotions in man and animals]. C. Darwin, P. Ekman. St. Petersburg: Piter Publ., 2001. 384 p. (in Russian).

7. Kabalevsky D. B. Osnovnye printsipy i metody programmy po muzyke dlya obshcheobrazovatel'noj shkoly [Basic principles and methods of music program for secondary school]. Muzyka. 1-3 klassy [Music. Grades 1-3]. Moscow: Prosveshchenie Pudl., 1988, pp. 1-32 (in Russian).

8. Loginova V. A. O muzykal'noj kompozitsii nachala XX veka: $k$ probleme avtorskogo stilya V. Rebikova, N. Cherepnina, A. Stanchinskogo [Musical compositions of the early XX century: the problem of the author's style of V. Rebikov, N. Tcherepnin, A. Stanchinsky]. Extended abstract of $\mathrm{PhD}$ dissertation (Arts History). Moscow, 2002. 22 p. (in Russian).

Submitted 02.03.2019; revised 15.03.2019.

About the author:

Valentin P. Reva, Associate Professor at the Department of Music and Aesthetic Education, Mogilev State A. Kuleshov University (Kosmonavtov Street, 1, Mogilev, Republic Belarus, 212022), PhD in Pedagogical Sciences, Associate Professor, val.r2014@mail.ru

The author has read and approved the final manuscript. 


\section{КОНЦЕПТУАЛЬНЫЕ ОСНОВЫ ВУЗОВСКОГО КУРСА «ТРАДИЦИОННАЯ МУЗЫКА В КУЛЬТУРЕ НАРОДОВ МИРА»}

\section{Ю. С. Овчинникова',}

Московский государственный университет имени М. В. Ломоносова, Москва, Российская Федерация, 119991

Аннотация. В России преподавание музыки народов мира реализуется в ряде вузов, осуществляющих подготовку по програлмал музыковедения, исполнительского и колпозиторского искусства, в единичных случаях - музыкально-педагогической направленности. В условиях диалога звуколузыкальных традиций и широкого освоения музыкального многоязычия мира в среде непрофбессиональных музыкантов особую значилость илеет введение в вариативный колпонент высшего гуланитарного образования учебной дисииплины, направленной на колплексное, междисииплинарное изучение традиционной музыки народов мира с ориентацией на развитие лежкультурной колпетентности будущих специалистов. Автор обобщает 12-летний опьт преподавания курса "Традиционная музыка в культуре народов мира" на факультете иностранных языков и регионоведения МГУ илени M. В. Лолоносова Раскрываются теоретические основы курса, его культурологическая специфика, телатический план, педагогические приёль и результаты работы.

Ключевые слова: традииионная музыка в культуре народов мира, этническая музыка, музыкальные культуры мира, традиционные музыкальные инструленты, концепиия курса, педагогические основы преподавания, музыкальная культурология.

Благодарности: Данная статья выполнена в ралках научного направления кафбедры сравнительного изучения национальных литератур и культур ббакультета иностранных языков и регионоведения МГУ илени М. В. Лолоносова «Традиционнье культуры в совреленнол мире».

Для цитирования: Овчинникова Ю. С. Концептуальные основы вузовского курса «Традиционная музыка в культуре народов мира» // Музыкальное искусство и образование. 2019. Т. 7. № 1. С. 40-59.

\footnotetext{
1 Научный консультант - доктор педагогических наук, профессор В. П. Кузовлев.
} 


\title{
Yulia S. Ovchinnikova',
}

Lomonosov Moscow State University, Moscow, Russian Federation, 119991

\begin{abstract}
In Russia the teaching of traditional music of peoples of the world is realized in higher education institutions with specialization in musicology, performing art and in solitary cases in music pedagogics. The actual dialogue between sound and musical traditions and acquisition of musical polylingualism of the world by nonprofessional musicians shows a clear need for including into the variable component of higher humanitarian education a subject focused on complex, interdisciplinary study of world music with orientation on development of intercultural competence of future specialists. The author generalizes her 12 years' experience in teaching the course "Traditional music in culture of peoples of the world" at the Faculty of Foreign Languages and Area Studies of Lomonosov Moscow State University for students of the following educational programs: "Linguistics and Intercultural Communication", "Area Studies and International Relations", "Culture Studies". Also the experience of teaching this course as interfaculty subject (2019) is recognized. The theoretical foundations of the course, culture study approach to the world music, pedagogical technics, music and cultural content, results of the work are regarded.
\end{abstract}

Keywords: traditional music in culture of peoples of the world, world music, ethnic music, musical cultures of the world, musical culture science, traditional musical instruments, conception of the course, pedagogical foundations of teaching, music and culture studies.

Acknowledgements: The article was prepared within the scientific field "Traditional cultures in the modern world" developed by the Department of Comparative Literature and Culture of Faculty of Foreign Languages and Area Studies of Moscow State University.

For citation: Ovchinnikova Yu. S. Conceptual foundations of the academic course "traditional music in culture of peoples of the world". Muzykal'noe iskusstvo $i$ obrazovanie = Musical Art and Education, 2019, vol. 7, no. 1, pp. 40-59.

\footnotetext{
1 Scientific consultant - Doctor of Pedagogical Sciences, Professor V. P. Kuzovlev.
} 


\section{Диалог звукомузыкальных традиций как тенденция развития мировой культуры конца XX - начала XXI века}

Во второй половине $\mathrm{XX}$ века в мировом художественном пространстве происходит усиление этнокультурного фактора, проявившееся во всех сфрерах искусства [1]. В музыке этот процесс нашёл отражение в таких френоменах, как «Фольклорное возрождение» в США, Канаде, Греции, Португалии, странах «кельтского» региона (Шотландия, Ирландия, фрранцузская Бретань, испанская Галисия), в движении «Новой песни» в странах Латинской Америки. Объединяло эти разные по содержанию «эксперименты» то, что все они происходили в области этнической музыки, создаваемой на основе освоения автохтонных традиций и адаптирующей фольклорные жанры к современным реалиям жизни. В репертуар музыкантов входили как народные, так и авторские произведения с включением образов и мотивов мифропоэтики, этнопоэтики и этноистории, актуальных политических и социальных проблем [2].

Новый этап ознаменовало рождение в 1980-х годах направления «Музыка народов мира», или «Мировая музыка» (World Music), обусловленного развитием глобальных процессов, коммерческой звукозаписи, интернета и новых возможностей межкультурного взаимодействия. Его ведущими представителями стали Р. Шанкар, Г. Белафонте, М. Макеба, Г. Брегович, О. Фарук, Дж. Гаспарян и др. В дальнейшем к этой категории музыкальной индустрии стали относить всё музыкальное творчество, основан- ное на использовании этноинструментов и этнического вокала, причём не только какой-либо одной традиции, но и в форме «диалога культур» в рамках одного произведения или концерта [2].

Наряду с коммерческой линией возникают и международные сощиальные инищиативы, например проект «Игра для перемен». Его участники с помощью переносной студии вовлекают в совместное творчество уличных, городских, сельских музыкантов разных традищий из индейских резерваций Америки, африканских городов и деревень, удалённых селений Гималаев и др. Главный импульс организаторов заключается в стремлении к творческому общению и преодолению гранищ: «Водимые... этими устремлениями... мы получали свободный доступ к музыкантам и местам, которые в обычных условиях недостижимы... Вдохновенное звучание наших песен показывает глубинные связи человечества и стремление к единению. Через музыку мы можем понимать наши различия и создавать лучший мир» [3].

Процесс освоения музыкального многоязычия мира, который развивается в большей степени в форме аутопедагогики (самостоятельного творческого поиска, самообучения через неформальное общение музыкантов разных культур и интернет-ресурсы), нашёл отражение не только в профессиональной сорере, но и в творчестве обычных людей, не имеющих специальной музыкальной подготовки. Так, в России сегодня существует большое количество фолк-групп, исполняющих традиционную музыку Ирландии, Шотландии, Индии, Кубы, Японии и стран Андского нагорья, североамериканских индейцев, фрламенко, музыку 
сефрардов и т. д. Следует упомянуть и мировое варганное движение, куда входят как профессиональные музыканты, так и люди, самостоятельно осваивающие инструмент в качестве хобби. Главным результатом этого процесса является живое приобщение молодёжи к миру иных культур и вместе с тем осмысление собственной идентичности. Поликультурность слуха и звукового сознания современного общества становится объективной реальностью [4], без учёта которой сегодня невозможна разработка полноценной, отвечающей современным вызовам стратегии развития гуманитарного образования.

\section{Традиционная музыка народов мира в современном образовании}

В содержание отечественного музыкального образования всё шире входит изучение музыки народов мира. Для музыковедов, композиторов и музыкантов-исполнителей эта тематика широко представлена в учебных дисциплинах В. Н. Юнусовой в Московской государственной консерватории (МГК) имени П. И. Чайковского (с 1995 года) [5], в курсах И. В. Мациевского в Петрозаводской государственной консерватории имени А. К. Глазунова (с 1992 года) [6], в курсе В. И. Лисового «Музыкальные культуры мира» в Российской государственной специализированной академии искусств (с 1992 года) [7] и др. Данные курсы отличаются теоретической направленностью, охватом в своём содержании структуры музыкальной культуры регионов (звуковой модели мира, музыкальных традиций, жанров, инструментов и др.), религиозно-фрилософрских концепций, отражённых в музыке, ориентацией на слушание и анализ музыкальных произведений как народного, так и композиторского творчества. Региональный охват в содержании дисциплин неоднороден и зависит от специализации педагога. Курсы в МГК имени П. И. Чайковского вводят слушателей в пространство музыкального востоковедения, между тем традиционной музыке Тропической Адрики уделяется меньше внимания, а материал по Северной и Южной Америке, региональным фольклорным традициям стран Европы в курсы не входит. Такое ограничение отчасти компенсируется лекциями И. А. Кряжевой по музыке стран Латинской Америки [8] и С. Ю. Сигиды по музыкальной культуре Северной Америки [9] в рамках курса «История зарубежной музыки». В Российской академии музыки имени Гнесиных в содержание курсов Т. М. Джани-Заде [10] входит музыка исламской цивилизации, регионов Востока, Африки, Австралии и Океании.

Богатый по региональным традициям материал в рамках одной дисциплины - «Музыкальные культуры мира» - находим у В. И. Лисового: это традиционная музыка народов Южной и Юго-Восточной Азии, Ближнего, Среднего и Дальнего Востока и Центральной Азии, Австралии и Океании, Тропической Африки, Северной, Центральной и Южной Америк. С 1998 года данная тематика была дополнена курсом «Народное музыкальное творчество», в котором, помимо зарубежного фольклора, представлена этническая музыка регионов России, а с 2014 года - курсом «Массовая музыкальная культура», опирающимся в том числе на этническую музыку народов мира [11]. Важ- 
но отметить и преподавание В. И. Лисовым курса «Музыка в культуре» (1991-1994) на фракультете журналистики Московского государственного института международных отношений (МГИМО).

В сфрере культурологического образования музыка народов мира введена Е. В. Васильченко в курс востоковедческой ориентации «Звук/музыка в системе культуры мировых цивилизаций» в Российском университете дружбы народов (РУДН) [12].

Особый подход, синтезирующий достижения музыкальной науки и культурологическую проблематику, представлен в учебно-методическом пособии А. С. Алпатовой «Архаика в мировой музыкальной культуре» [13], которое было подготовлено для студентов Российской международной академии туризма, Института бизнеса и политики и других московских вузов.

В отдельных случаях в дополнение к теоретическим дисциплинам организуется практическая работа по освоению музыкальных инструментов разных традиций. В научно-творческом центре «Музыкальные культуры мира» в МГК имени П. И. Чайковского проводится обучение японской, китайской, индийской и иранской музыке [14]. Курс Е. В. Васильченко в РУДН сопровождается классами-лабораториями по обучению игре на музыкальных инструментах Востока.

В вузовском музыкально-педагогическом образовании уникальная авторская методология освоения музыки народов мира разработана Е. В. Николаевой в рамках курса «Национальные образы мира в традиционной культуре народов Австралии, Азии, Америки, Афррики, Европы» [15], который уже более 10 лет преподаётся на музыкальном фpaкультете Института изящных искусств МПГУ. Данный курс отличает широкий региональный охват, полидеятельностный профессиональноориентированный подход к работе с аудиозаписями детских народных песен в аутентичном исполнении, музыкально-педагогический анализ видеозаписей песенных и инструментальных образцов музыкального фольклора народов мира [16]. В результате у обучающихся актуализируется и расширяется арсенал музыкальнопедагогических средств, формируются компетенции, свидетельствующие о готовности будущих музыкантов-педагогов к педагогическому руководству процессом приобщения молодого поколения к музыке народов мира в рамках общего и дополнительного музыкального образования.

Bce обозначенные явления говорят о востребованности данной дисциплины в отечественном образовании. Однако в отличие от западного опыта, где практическое освоение музыки других цивилизаций стало одним из важнейших направлений музыкального образования [17, с. 559], в России оно ещё находится на стадии формирования. Кроме того, в условиях широкого освоения музыкального многоязычия мира в среде непрофрессиональных музыкантов особую значимость может иметь введение в вариативный компонент высшего гуманитарного образования учебной дисциплины, направленной на комплексное, междисциплинарное, деятельностное изучение традиционной музыки народов мира с ориентацией на развитие межкультурной компетентности будущих специалистов. Опыт разработки курса «Традиционная му- 
зыка в культуре народов мира» предпринят автором на кафедре сравнительного изучения национальных литератур и культур фракультета иностранных языков и регионоведения МГУ имени М. В. Ломоносова (с 2007 года по настоящее время) и на кафредре музыкального образования Елецкого государственного университета имени И. А. Бунина (2011-2014).

\section{Теоретические основы курса «Традиционная музыка в культуре народов мира» для студентов немузыкальных специальностей}

В качестве теоретических основ созданного нами курса выступают современные школы и концепции в области фрилософии, музыковедения, музыкальной психологии, инструментоведения, литературоведения и культурологии: интегративный фрилософрско-культурологический подход к изучению музыки (Г. Орлов) [18]; регионально-цивилизационный подход к изучению музыкальной культуры (Дж. К. Михайлов) [19]; музыкальное востоковедение (В. Н. Юнусова) [20]; исследования архаики в мировой музыкальной культуре (А. С. Алпатова) [13]; школа петербургского инструментоведения (И. В. Мациевский) [21]; концепция национальных образов мира (Г. Гачев) [22]; культурологические концепции этноискусства и сравнительной мифологии (А. В. Ващенко) [1; 23].

Г. Орловыли в рамках фбилософбскокультурологического подхода к изучению музыки были разработаны следующие позищии: преодоление европоцентристского взгляда на музыку и создание единого метаязыка теории для описания музыкальных культур мира; выявление фракторов психики как исходных стимулов музыкального творчества, изучение музыкального поведения в разных культурах; рассмотрение музыки в контексте картины мира, выявление связей со всеобщими формами существования (опыт, время, пространство) [24]; понимание музыки «в свете общих ценностей, верований и способов восприятия, которые образуют ядро каждой культуры и определяют её внутреннее единство» [18, с. хі]. Автор выявляет онтологическое единство музыки и культуры и видит в музыке «особую ипостась культуры, специфичное проявление её жизненной силы и сущности - часть культуры, тождественную целому» [Там же, с. 339], обозначая два локуса исследования: музыка в культуре и культура в музыке. Учёный не ставил своей целью комплексное рассмотрение отдельных локальных традиций, его роль в контексте наших задач заключается в выявлении фундаментальных основ и параметров для сравнительного изучения традищионных музыкальных культур.

Музыкальная культурология Дж. К. Михайлова, разработанная в рамках курса «Музыкальные культуры мира» (1980-1990-е годы) в МГК имени П. И. Чайковского, стала первым проектом в отечественном образовании, направленным на изучение лировых иивилизаиий как звуколузыкальных обшностей. Опорными точками концепции автора, имеющими особое значение для культурологов, стали: системный подход к исследованию музыкальных культур; теория музыкально-культурной традиции; учёт особенностей мировосприятия и мышления, в том числе музыкального, у разных народов; понятие «музыкальный глобус»; принщипы и 
критерии регионирования (экологическая специфика, способ производства, языковая и конфессиональная общность, единство традиций материальной и духовной культуры) [25, с. 57].

Дальнейшая разработка и развитие методологии Дж. К. Михайлова была раскрыта в трудах его учеников и последователей в России и за рубежом. Охарактеризуем те из них, которые послужили теоретическими основаниями для разработки нашего курса.

Это, прежде всего, исследования B. Н. Юнусовой, ставшие основополагающими для отечественного музыљкального востоковедения [20], опыт разработки автором курса «История внеевропейских музыкальных культур» и составления совместно с А. В. Харуто сборников материалов конференций по проблемам музыки народов мира, в которых систематизирован широкий корпус ведущих музыковедческих исследований в данной области [26].

Исследования архаики в мировой музыкальной культуре в трудах A. C. Алпатовой [13] представляют методологически важную концепцию звуковой картины мира (ЗКМ) в архаической и традиционной культуре. Автор определяет ЗКМ как образ мира и семиосферу архаической и традиционной культур, охватывающую совокупность представлений о человеке и окружающем мире, сложившуюся в условиях данных типов культуры и проявляющуюся через звук и звучание. Структурировать и сопоставлять эмпирический материал по различным традициям позволяют сфреры ЗКМ - культурофония и её производные (для каждой даётся осмысление внутренней структуры и содержания): биофония; мифоорония и социодрония [Там же, с. 94-98].

Следует отметить также фундаментальные труды в сорере этноинструлентоведения И. В. Мациевского. Перечислим наиболее важные для нашего дискурса позиции учёного: френомен инструментализма (исполнительские школы, способы передачи традиций, изготовления инструментов и обучения игре); традиционные музыкально-фрилософрские представления, этнопсихология, эстетика, теория и терминология музыки в контексте быта и творческой практики музыкантов; проблемы бытования и фрункционирования народной музыки; её взаимосвязь с традиционной художественной культурой; исследования художественного текста [21]; концепция контонации [27].

Концепиия Г. Гачева о триединстве "Косло-Психо-Логоса" позволяет выйти на более широкий культурологический уровень изучения локальных музыкальных традиций. Речь идёт о взаимосвязи природного ландшадта и типа хозяйствования с национальным характером (миросозерцанием) и складом мышления, «космологосом» [22], отражёнными в традиционной музыке. Представляет интерес и натурфилософрский язык четырёх стихий, к которому обращается автор в контексте деления музыкальных инструментов в зависимости от преобладания в их конструкции и звучании Земли, Воды, Огня или Воздуха.

Культурологические концепиии A. В. Ващенко служат теоретическим основанием для раскрытия следующих аспектов: категории анализа в сравнительной мифологии в контексте культуры и цивилизации (мифологическое время-пространство (хро- 
нотоп - М. М. Бахтин), мифрологический герой (сущность, ипостаси, парадигма пути), мифрологическая героиня, символика мифологического образа в реалиях культуры, «животные» сюжеты от мифрологии к цивилизации и др.) [23]; сущностные блоки этнопоэтики в современном искусстве (магия мифа и синкретизм элементов в этнодискурсе; время-пространство; сакрализация природного начала; сказительство, память, действо, традиция; общинность этики и категория имени; языковая идентичность, билингвизм; типология героя: маргинальный герой; трикстер; герой-этнос) [1].

Таким образом, специфика культурологического подхода в изучении традиционной музыки народов мира в рамках дисциплины «Традиционная музыка в культуре народов мира» определяется: системным подходом к исследованию музыкальной культуры и её составляющих; междисциплинарностью (проблема изучается на стыке различных областей: литературоведения, искусствоведения, лингвистики, этнографрии, культурной антропологии, психологии, философии, истории и др.); стремлением к комплексности исследования и к получению объёмной картины изучаемой культуры (к установлению связей и смысловых соответствий между различными явлениями культуры и жизни человека); сочетанием методов разных наук.

\section{Содержательная характеристика вузовской учебной дисциплины «Традиционная музыка в культуре народов мира»}

Курс «Традиционная музыка в культуре народов мира» разработан автором на фракультете иностранных языков и регионоведения МГУ для студентов, обучающихся на отделениях «Лингвистика и межкультурная коммуникация», «Региональные исследования и международные отношения» (2007-2014). С открытием в 2009 году отделения культурологии он был включён в качестве вариативной дисциплины в программу подготовки бакалавров по данному направлению, с 2019 года стал читаться в форме межфракультетских лекций для студентов МГУ разных специальностей. Изначально курс был рассчитан на два семестра с лекщионными и семинарскими занятиями (4 часа в неделю), начиная с 2013 года на один семестр (2 часа в неделю). Среди ключевых особенностей его построения выделим следующие:

- регионально-локальный подход к изучению традиционной музыки народов мира в историко-культурном контексте;

- опора на полевые исследования автора (артефракты, инструменты, видеозаписи, тексты бесед с музыкантами, дневниковые заметки, аудио- и фотоматериалы);

- использование традиционных музыкальных инструментов из личной коллекции автора;

- включение в качестве материала как песенных, так и инструментальных образцов традищионной музыки;

- изучение музыкальных традиций в следующих ракурсах: отражение реалий этнокультуры в традиционной музыке и репрезентация образов и мотивов локальной музыкальной традиции в фольклоре, живописи, кинематографре и др.;

- привлечение к курсу носителей различных музыкальных традищий, как из студенческой среды, так и из круга друзей и коллег преподавателя. 
Основная идея курса - найти общее и особенное в традиционной музыкальной культуре разных народов, изучая музыку как культурологическое явление, позволяющее глубже понимать этнические картины мира, развивать межкультурную компетентность, а также содержательно, эмоционально-чувственно и эстетически сонастраиваться с пространством изучаемых традиций для более объёмной и правильной интерпретации различных данных (этнографических, лингвистических, искусствоведческих и др.).

В качестве задач дисциплины выступают:

- компаративное изучение традиционной музыки народов России и других стран на основе материалов, собранных автором во время полевых исследований, личного архива и данных современной науки;

- знакомство с культурологическим подходом к исследованию традиционной музыки во взаимосвязи с мифологией, фольклором, аксиологией, исторической памятью, национальным характером, образом жизни, обрядами и праздниками, этнопедагогикой, музыкотерапией, спецификой процессов этнокультурной идентификации народов через музыку в современном мире и др.;

- изучение истории происхождения, әволюции, символики и взаимосвязи музыкальных инструментов разных стран и народов;

- освоение образно-смыслового содержания традиционной музыки;

- изучение методов компаративного анализа явлений музыкальной культуры;

- знакомство с теорией и практикой полевых исследований әтномузыкальных культур;
- развитие исследовательской деятельности студентов, а также самопознания и творческих способностей.

Курс «Традиционная музыка в культуре народов мира» не ставит своей задачей охватить все музыкальные культуры мира. Тематика лекций обусловлена личным опытом практического освоения и последующего научного теоретического осмысления музыки разных народов во время музыкально-этнографических поездок (Индия, Испания, Португалия, Марокко, Греция, Шотландия, Литва, Парагвай) и әкспедиций автора (в Мексику, в регионы России: Башкирия, Хакасия, Якутия, Алтай и др.), а также в процессе творческого общения и совместного музицирования с представителями других стран (Литва, Ирландия, Мексика, Куба, Иран, Эквадор, Канада, Китай, США, Бразилия, Аргентина, Австралия и др.).

Междисциплинарный характер исследования традиционной музыки определяет комплексный подход к изложению материала. Тематически курс состоит из трёх разделов. Каждый из них имеет своё смысловое ядро (принцип объединения разных тем) и направлен на решение различных педагогических задач.

Первый раздел - «Музыкальное мироведение в контексте сравнительного изучения традиционных культур» - раскрывает теоретические основы курса (основные понятия, школы, специфику культурологического подхода и междисциплинарного диалога в изучении традиционной музыки) и ряд аспектов культурологической компаративистики. С педагогической точки зрения он направлен: 
- на вдохновение и мотивацию студентов к изучению данного курса;

- на развитие субъектного отношения к окружающему звукомузыкальному пространству и использованию музыки в своей жизни;

- на развитие рефлексии относительно проблемы отчуждения человека в условиях современного города;

- на актуализацию аксиологической основы музыкального творчества, создание условий для осуществления нравственного выбора в процессе создания произведений и формирования музыкальных предпочтений;

- на развитие распознавания живого и неживого в музыке, гармоничного и негармоничного с точки зрения влияния на жизнь человека, общества и природы;

- на развитие исследовательской деятельности обучающихся.

Поставленная проблематика раскрывается в следующих телах:

1. Традиционная музыка народов мира как предмет культурологии.

2. Отношение «Человек - Мир» в контексте сравнительного изучения музыкальных традиций разных народов.

3. Звуковой ландшафт и звуковая картина мира в традиционной культуре.

Для живого вовлечения студентов в учебный процесс каждая из тем раскрывается на примере широкого «звучащего» этноинструментария (в качестве иллюстративного материала на столе у преподавателя около 50 инструментов); сопровождается пением педагога различных образцов этнического фольклора, а также видеоматериалами из полевых записей автора; опирается на художественно оформленные презентации основных тези- сов. Географический ареал, задействованный в этом разделе, отличается широтой охвата как по континентам, так и по регионам России, в то время как целевая направленность учебных тем предполагает выявление общего и особенного в разных традиционных культурах. Практические задания для самостоятельной работы связаны с полевой исследовательской деятельностью, творческим слушанием музыки и звукового ландшафта, направлены на развитие рефлексии относительно рассматриваемых проблем, включают чтение и анализ мифологических, фольклорных, а также научных текстов, анализ этнических видеофильмов и др.

Во второл разделе - «Музыкальные картины мира: единство в многообразии» - рассматриваются различные грани этнокультурных миров сквозь призму традиционной музыки. С педагогической точки зрения он направлен на развитие межкультурной компетентности студентов в следующих параметрах:

- субъектность обучающихся (понимание себя, своих жизненных замыслов и становление авторства собственной жизни; авторская позиция является непременным условием успешного межкультурного диалога);

- способность к сопереживанию и децентрации;

- знания о конкретных этнических традициях;

- опора на аксиологический подход к изучению различных музыкальных культур (способность объяснять те или иные особенности Другого на основе ценностных этнокультурных смыслов);

- творческий опыт (для восприятия плодов творчества Другого необ- 
ходимо иметь хотя бы небольшой, но свой аналогичный опыт порождения художественного произведения);

- актуализация эмоционального и чувственного Я, предполагающая осознавание информации, полученной через органы восприятия, и понимание своих эмоций и эмоций представителя другой культуры [28];

- владение специфическими культурными средствами переживаниядеятельности как процесса смыслопорождения.

В условиях одного семестра в учебный материал нами включены следующие этнонациональные традиции (список может варьироваться в зависимости от пожеланий обучающихся на основе более широкой программы, разработанной нами ранее для двухсеместрового курса, рассчитанного не на 2 , а на 4 часа в неделю):

1. Музыка как духовный путь: культурологические аспекты музыкального творчества в индийской традиции.

2. Аксиология музыкального творчества в традиционной культуре Китая.

3. Влияние суфизма на традиционную музыку Ирана, Турции, Пакистана.

4. Истоки и эволюция музыкальной культуры Греции.

5. Клановые традиции музыкального творчества в гэльской Шотландии.

6. Роль музыкального творчества цыган в мировой музыкальной культуре.

7. Культ предков в региональных музыкальных традициях Тропической Африики.

8. Сердце в ритме с природой: музыкальный космос коренных американцев.

9. Жизнь и смерть в традиционной музыкальной культуре Мексики.
10. Музыка, песня и танец в контексте музыкоцентризма кубинской культуры.

11. Смысловая гамма аргентинского танго: дух портеньо и БуэносАйреса.

12. Встреча культур: место музыки кантри и вестерн в национальной культуре США.

Ориентируясь на развитие субъектности обучающихся, к каждой теме разработано от пяти до восьми заданий различной содержательной направленности и типологии. В зависимости от личных интересов и индивидуальной траектории развития обучающийся может выбрать любой из вопросов для самостоятельной работы: работа с вербальными фольклорными текстами; слушание, расшифровка и анализ музыкальных произведений; работа с этноинструментарием; просмотр и анализ этнического кино; создание художественного произведения (музыкальной композиции, картины, видеофильма, эссе) как формы переживания другой культуры и др.

Третий раздел - «Традиционная музыка в современном мире: актуальные вызовы и прикладные аспекты применения в культурной практике» - раскрывает роль музыки в процессах межкультурного взаимодействия. Педагогически он ориентирован: на развитие исследовательской деятельности в области музыкальной культурологии и актуальных вопросов, связанных с проблемой этнокультурной идентификации через музыку в современном мире; на самопознание и актуализацию своих жизненных замыслов; на развитие компетенций, позволяющих применять полученные знания 
в профессиональной практике (образовательной, культурной и др.) и в собственной жизни.

Эти задачи реализуются в рамках следующих тем:

1. Аксиология миротворчества в этномузыке второй половины XX начала XXI века: от «фольклорного возрождения» к World Music.

2. Формы репрезентации этнической идентичности в творчестве современных музыкантов.

3. Развивающий потенщиал традиционных музыкальных этноинструментов в культурной, педагогической и арт-терапевтической практике.

Самостоятельная работа осуществляется через проведение полевых исследований по заданным параметрам (социологический анализ концертов этнической музыки, анализ музыкальных форм репрезентации этничности в интернете и др.), через разработку собственного творческого проекта (в любой профессиональной или личной сфрере), связанного с использованием различных аспектов традиционной музыки народов мира.

\section{Педагогические основы курса}

Различные аспекты теории и методологии курса подробно освещены нами в ряде статей [28-34]. Основными принципами его построения выступают: принцип междисциплинарности; принцип деятельностного подхода к обучению «от действия к наблюдению и осмыслению действия, применению нового опыта в других жизненных контекстах»; принцип создания на занятиях пространства «защищённого мира» для личностного, творческого и духовного раскрытия человека; принцип обучения «через самопознание к по- знанию мира»; принцип организации художественного опыта как переживания-деятельности по перестройке внутреннего мира [29].

Bсе эти принципы, взятые в системе, позволяют преодолеть границы чисто искусствоведческого подхода к музыке в сторону междисциплинарности и диалога в современном научно-образовательном дискурсе, связать полученные знания, включив их в объёмную картину разнообразных культурных миров, помогают выстраивать отношения со студентами не только на знаниевом уровне, но и на уровне целостной личности, учитывая индивидуальные особенности, запросы, интересы, траектории саморазвития. Комплексное осмысление образовательных отношений способствует духовному росту как педагога, так и обучающихся, формированию истинно творческой личности, опирающейся на фрундаментальные знания, способной к диалогу, к глубокому осмыслению и самостоятельному порождению новых форм трансляции и развития культуры.

Лекционно-практические занятия разрабатываются на основе субъектнодеятельностной парадигмы образования, в рамках которой в качестве ключевого механизма освоения материала служит концепция переживания как деятельности по перестройке внутреннего мира и как процесса смыслопорождения (Ф. Е. Василюк) [35].

Для реализации работы переживания как способа познания мира используется ряд приёмов. Так, одним из вариантов подачи лекционного материала является «музыкальное сказительство», вовлекающее слушателей в процесс живой передачи лично- 
го опыта педагога в области познания различных культур (подробнее см. [31]). Этот приём опирается на творческое переосмысление традиции народного сказительства и подразумевает построение речи педагога на основе синтеза научного и художественного дискурса: научные позиции раскрываются через живые метафоры и художественные образы, которые говорящий внутренне проживает в процессе рассказывания, подкрепляя их наглядными музыкально-звуковыми примерами (пением, игрой на инструментах, полевыми записями).

В отличие от искусствоведческих дисциплин, направленных на слушание и анализ музыкальных произведений других традиций, особенностью нашего курса выступает включение практических элементов, в частности игры на традиционных этноинструментах и исполнения песен разных народов. В условиях ограниченного времени мы не имеем возможности осуществить глубокую работу по освоению этноинтонирования в том объёме, в каком она реализуется в курсе Е. В. Николаевой. Наша практика связана с прослушиванием, расшифровкой, анализом и исполнением музыкальных произведений, но при этом направлена не столько на то, чтобы добиться высокого качества исполнения, сколько на реализацию деятельности сопереживания другой культуры, самостоятельного внутреннего усилия по её освоению, что «оказывает глубинное воздействие на обучающихся, при котором мир Другого не просто обретает определённое место во внутреннем мире реципиента, но в корне преобразует его, придавая ему совершенно новое качество» [30, с. 34].
Ещё одной отличительной особенностью курса является привлечение музыкальных инструментов из личной коллекции автора, которая собиралась с 1998 года и насчитывает более 150 наименований. Выделим две основные в педагогическом отношении группы инструментов.

Первую из них составляют инструменты, относительно простые для освоения, выполненные из природных материалов, имитирующие звуки природы: мексиканский свисток в виде ягуара, зимбабвийская калимба, тибетская поющая чаша, испанские барабан ветра и дерево дождя, турецкие тарелки зиль, казахская домбра, мексиканский тепонацтли, индийская равантха, кубинский клавес, боливийские чакчас, перуанские и парагвайские погремушки, этнические разновидности фрлейт Пана, вьетнамские деревянные жабы, зулусский барабан, марокканский бендир и др. [29, с. 16].

Во вторую группу входят инструменты, игру на которых могут продемонстрировать преподаватель, студенты, имеющие подготовку, или носители соответствующих традищий. Это индийские табла и ситар, молдавский фрлуер, сербская фррула, парагвайская арфа, греческий бузуки, турецкий саз-джура, венесуэльский куатро, аргентинский чаранго, китайские эрху, хуласы, ди, сюнь и др. Эти инструменты выступают важным этнографическим артефрактом, и все обучающиеся могут изучить его визуальную специфику и структуру.

Курс предполагает использование авторских интерактивных методик работы с этноинструментарием. Первая группа таких методик связана с развитием исследовательской 
деятельности обучающихся в области комплексного междисциплинарного изучения традиционных культур [29]. Музыкальный инструмент как живой артедракт этнокультуры позволяет наглядно и практически осуществлять индивидуальный поиск в широком спектре направлений и находить между ними глубокие взаимосвязи: конструктивные особенности и материалы локальной природы, использующиеся при изготовлении инструмента; формы развития математических средств в контексте этнокультуры (антропометрический счёт в изготовлении инструментов); связь музыкального инструмента с традициями быта и хозяйственной деятельности; мифологические представления и особенности этнического миросозерцания; музыкальный инструмент и обряд; творческая личность мастера и исполнителя; специфика звукоизвлечения и темброартикуляции; представления об этническом звукоидеале; инструмент как символ этнической идентификации и др. Кроме того, само наличие в качестве артедакта живых этноинструментов во всём многообразии форм и звучаний (в отличие от абстрактных теоретических конструкций) естественным образом активизирует у студентов познавательный интерес, который можно органично переводить в целенаправленную исследовательскую деятельность.

Вторая группа методик связана c организацией совместных музыкальных игр-импровизаций и направлена на развитие ценностных оснований духовной культуры студентов, субъектности, самопознания, редлексии, межкультурной компетентности, творческой работы с инто- нируемым переживанием [29; 32 ; 33]. Важно, что в этих методиках мы опираемся не только на использование возможностей комплексного воздействия на человека этих инструментов (звукового, телесно-тактильного, визуального, образно-символического и др.), но прежде всего на внутреннюю работу субъекта в процессе развёртывания музыкального переживания как процесса порождения жизненных смыслов. То есть студент в данном случае выступает не как объект воздействия различных звукомузыкальных средств, но как субъект и автор собственной жизни. При этом каждая музыкальная импровизация имеет определённую задачу на смысл, например:

- познание мира другой культуры через внутренний диалог с её этноинструментарием (индивидуальное освоение игры на инструменте происходит без носителя интонирования; при этом особое внимание уделяется рефолексии, тому, какие чувства вызывает тактильное взаимодействие с его формами и материалами, какие ассоциации, мысли, образы рождает звук и т. д.);

- практическое изучение основ гармоничного мироустроения в музыке и в жизни через импровизацию на инструментах музыкальной игры «Совместное творение мира в звуках» (возможно при наличии от трёх до десяти участников);

- развитие способности к диалогичности, к слушанию, слышанию и пониманию другого (совместная музыкальная импровизация в дуэте);

- переживание, осмысление и построение своего жизненного пути через музыкальные метафоры (когда осуществляется творческая работа 
с интонируемым переживанием и один участник выступает в качестве «композитора» своего жизненного пути, а аудитория помогает ему осуществлять авторский замысел, включаясь с другими инструментами и поддерживая ведущего);

- развитие способности к сопереживанию в процессе совместной игры (поддерживая интонируемое переживание Другого посредством своего инструмента, важно оставаться в этой задаче, не переходить на другие и не перехватывать инициативу) и др.

Перечисленные компоненты в своей совокупности помогают организовывать непрерывный творческий образовательный процесс, лежащий в основе как любой исследовательской деятельности, так и внутреннего развития человека, - работу деятельности переживания как средства познания себя и Другого, порождая новые, ценностные, личностно значимые жизненные смыслы.

\section{Заключение}

Анализ данных рефрлексивного самоотчёта студентов, проведённого по результатам изучения нашего курса, выявил системные изменения, затрагивающие различные сто- роны внутреннего мира личности: обретение веры в себя, в возможность собственной творческой реализации; расширение знаний о мировой музыкальной культуре; осознание личностных смыслов музыки; развитие эмоциональной отзывчивости на музыку инонациональных культур, а также межкультурной сензитивности и понимания разных этнических традиций; получение опыта самопознания, осмысление его ценности в своей жизни; изменение отношений в группе (лучшее понимание и чувствование друг друга); более внимательное, открытое, бережное отношение к другим и к окружающему миру в целом; использование музыки для гармонизации собственной жизни и жизни общества; осмысление миротворческой роли музыки [34]. Данный эмпирический материал показывает важность и необходимость дальнейшей научной разработки как музыкально-культурологического содержания, так и психолого-педагогической методологии учебных дисциплин, реализующих деятельную, преобразующую роль традиционной музыки разных народов в современном мире.

\section{БИБЛИОГРАФИЯ}

1. Ващенко A. В. Возвращение на Итаку: этнокультурный фактор в художественном пространстве второй половины ХХ века. М.: Изд-во ФИЯР МГУ. 2013. 150 с.

2. Овчинникова Ю. С. Аксиология миротворчества в этнической музыке второй половины ХХ начала XXI в. // История: факты и символы. 2017. № 1. С. 40-49.

3. Playing for Change. URL: http://playingforchange.com/journey/introduction (accessed: 15.01.2019).

4. Каратыгина M. "Musical multiculturalism" и современные возможности взаимопознания культур через звук и музыку // Множественность научных концепций в музыкознании : сб. ст. к 60-летию Е. М. Левашёва. М., 2009. С. 106-126. URL: http://www.worldmusic center.ru/ musical-multiculturalism-sovremennye-vozmozhnosti-vzaimopoznaniya-kultur-cherez-zvukmuzyku (дата обращения: 15.01.2019). 
5. Юнусова Виолетта Николаевна / Московская государственная консерватория им. П. И. Чайковского; Юнусова В. Н. Педагогическая деятельность. URL: http://www.mosconsv.ru/ru/ person.aspx?id=8839 (дата обращения: 15.01.2019).

6. Мациевский Игорь Владимирович / Петрозаводская государственная консерватория им. А. К. Глазунова. URL: http://glazunovcons.ru/conservatory/staff/kafedra_muzyki_finnougor skih_narodov/macievskij_igor_vladimiro vich (дата обращения: 15.01.2019).

7. Лисовой Владимир Иванович / Российская государственная специализированная академия искусств. URL: http://rgsai.ru/ob-akademii/pedagogicheskij-sostav?id= 269 (дата обращения: 15.01.2019).

8. Кряжева Ирина Алексеевна / Московская государственная консерватория им. П. И. Чайковского. URL: http://www.mosconsv.ru/ru/person.aspx?id=8803 (дата обращения: 15.01.2019).

9. Сигида Светлана Юрьевна / Московская государственная консерватория им. П. И. Чайковского. URL: http://www.mosconsv.ru/ru/person.aspx?id=8932 (дата обращения: 15.01.2019).

10. Джани-Заде Тамила Махмудовна / Российская академия музыки имени Гнесиных / T. М. Джани-Заде. URL: https://gnesin-academy.ru/dzhani-zade-tamila-mahmudovna/ (дата обращения: 15.01.2019).

11. Лисовой В. И. История музыки и современная музыкальная культура. Мексика и Центральная Америка: учеб. пособие для вузов. 2-е изд. М. : Юрайт, 2019. 200 с.

12. Васильченко Елена Викторовна / Российский университет дружбы народов. URL: http:// www.rad.pfu.edu.ru/veduschie-uchenye/zasluzhennye-deyateli-nauki-professora-rudn/vasil chenko-elena-viktorovna (дата обращения: 15.01.2019).

13. Алпатова A. С. История музыки. Архаика в мировой музыкальной культуре: учебник для вузов. 2-е изд. М.: Юрайт, 2019. 247 с.

14. Научно-творческий центр «Музыкальные культуры мира» / Московская государственная консерватория имени П. И. Чайковского. URL: http://www.mosconsv.ru/ru/groups. aspx?id=124216 (дата обращения: 04.03.2019).

15. Николаева Елена Владимировна / Московский педагогический государственный университет. URL: http://mpgu.su/staff/nikolaeva-elena-vladimirovna (дата обращения: 15.01.2019).

16. Николаева E. B. Традиционная музыкальная культура народов мира как компонент вузовского музыкально-педагогического образования // Вестник кафедры ЮНЕСКО «Музыкальное искусство и образование». 2018. № 4 (24). С. 145-162.

17. Васильченко E. В. Диалог звукомузыкальных традиций в системе мировых цивилизаций // Феномен творческой личности в культуре. Фатющенковские чтения: материалы III Международной конференции / отв. ред. А. В. Ващенко, М. Д. Потапова. М.: Изд-во МГУ. С. 548-564.

18. Орлов Г. Древо музыки. Вашингтон: Н. А. Frager \& Сo; СПб.: Советский композитор, 1992. $403 \mathrm{c}$.

19. Михайлов, Дж. К. К проблеме теории музыкально-культурной традиции // Музыкальные традиции стран Азии и Африки: сборник науч. тр. М.: Изд-во МГДОЛК им. П. И. Чайковского, 1986. С. 3-20.

20. Юнусова В. Н. Творческий процесс в классической музыке Востока: автореф. дис. ... д-ра искусствоведения. М.: Изд-во МГДОЛК им. П. И. Чайковского, 1995. 37 с.

21. Мачиевский И. В. Народная инструментальная музыка как феномен культуры. Алматы: Дайк-Пресс, 2007. 520 с.

22. Гачев Г. Д. Космос-Психо-Логос: Национальные образы мира. М.: Академический проект, 2007. $511 \mathrm{c}$. 
23. Ващенко А. В. Суд Париса: сравнительная мифология в культуре и цивилизации. М.: Изд-во ФИЯР МГУ, 2008. 134 с.

24. Гаврюшенко H. Творческие начала и теоретические основы концепции Г. А. Орлова // Сравнительное искусствознание XXI век. Вып. 1: Наследие Генриха Орлова и актуальные проблемы современного сравнительного искусствознания: сб. статей и материалов. Ч. 1 / ред.сост. О. В. Колганова; отв. ред. И. В. Мациевский. СПб.: Изд-во РИИИ РАН, 2014. С. 48-68.

25. Юнусова В. Н., Алпатова А. С. Музыкальные культуры мира в научной и педагогической деятельности Дж. К. Михайлова (к 80-летию со дня рождения) // Музыковедение. 2018. № 1. С. 52-61.

26. Музыка народов мира: проблемы изучения: материалы международных научных конференций. Вып. 1. М.: Изд-во Московской консерватории, 2008. 416 с.

27. Мациевский И. В. В пространстве музыки. СПб.: Изд-во РИИИ РАН, 2011. Т. 1. 206 с.

28. Ткаченко Н. В., Овчинникова Ю. С. Психолого-педагогическая подготовка полевого исследователя: развитие аффективного компонента личности средствами традиционной музыки народов мира // Концепт: научно-методический электронный журнал. 2018. № 6. С. 78-90.

29. Овчинникова Ю. С. Традиционные музыкальные инструменты народов мира как деятельностное средство педагогики синтеза // Вестник кафедры ЮНЕСКО «Музыкальное искусство и образование». 2015. № 1 (9). С. 11-24.

30. Овчинникова Ю. С. Традиционные песни народов мира как деятельностное средство понимающего сопереживания другой культуры // Вестник кафедры ЮНЕСКО «Музыкальное искусство и образование». 2016. № 4 (16). С. 25-36.

31. Овчинникова Ю. С. Музыкальное сказительство в образовательной практике: сущность, содержание, условия и формы организации // Вестник кафедры ЮНЕСКО «Музыкальное искусство и образование». 2017. № 2 (18). С. 135-149.

32. Овчинникова Ю. С. Творческая работа с интонируемым переживанием как средство развития музыкальной культуры личности // Вестник кафедры ЮНЕСКО «Музыкальное искусство и образование». 2018. № 3 (23). С. 68-82.

33. Овчинникова Ю. С. Самопознание как необходимый компонент музыкального образования: музыкальные категории как метафоры внутренней жизни человека // Вестник кафедры ЮНЕСКО «Музыкальное искусство и образование». 2018. № 1 (21). С. 38-49.

34. Овчинникова Ю. С. Педагогические основы развития одарённости средствами традиционной музыки народов мира // Проблемы современной науки и образования. 2018. № 4. С. 187-204.

35. Василюк Ф. Е. Психология переживания. М.: Изд-во МГУ, 1984. 240 с.

Поступила 06.03.2019; принята к публикаиии 15.03.2019.

\section{Об ав торе:}

Овчинникова Юлия Сергеевна, доцент кафедры сравнительного изучения национальных литератур и культур фракультета иностранных языков и регионоведения Московского государственного университета имени М. В. Ломоносова (Ленинские горы, 1, Москва, Российская Федерация, 119991), кандидат культурологии, julia.barkova@gmail.com

Авторол прочитан и одобрен окончательный вариант рукописи. 


\section{REFERENCES}

1. Vashchenko A. V. Vozvrashchenie na Itaku: etnokul'turnyi faktor v khudozhestvennom prostranstve vtoroi poloviny XX veka [Return to Ithaca: Ethnocultural factor in artistic space of the second half of the 20th century]. Moscow: FIYaR MGU Publ., 2013. 150 p. (in Russian).

2. Ovchinnikova Yu. S. Aksiologiya mirotvorchestva $v$ etnicheskoi muzyke vtoroi poloviny XX nachala XXI v. [Axiology of peacekeeping in ethnic music of the second half of XX beginning of XXI centuries]. Istoriya: fakty i simvoly History: facts and symbols, 2017, no. 1, pp. 40-49 (in Russian).

3. Playing for Change. Available at: http://playingforchange.com/journey/introduction (accessed: 15 January 2019).

4. Karatygina M. "Musical multiculturalism" i sovremennye vozmozhnosti vzaimopoznaniya kul'tur cherez zvuk i muzyku ["Musical multiculturalism" and modern possibilities of inter-understanding of cultures through sound and music]. Mnozhestvennost' nauchnykh kontseptsii v muzykoznanii [Multiplicity of scientific conceptions in musicology]. The collection of articles in occasion of 60th birthday of E. M. Levashev. Moscow, 2009, pp. 106-126. Available at: http://www.worldmusiccenter. ru/musical-multiculturalism-sovremennye-vozmozhnosti-vzaimo poznaniya-kultur-cherez-zvukmuzyku (accessed: 15 January 2019) (in Russian).

5. Yunusova Violetta Nikolaevna. Moscow State Tchaikovsky Conservatory. Available at: http://www. mosconsv.ru/ru/person.aspx?id=8839 (accessed: 15 January 2019) (in Russian).

6. Matsievsky Igor' Vladimirovich. Petrozavodsk State Glazunov Conservatoire. Available at: http:// glazunovcons.ru/conservatory/staff/kafedra_muzyki_finnougorskih_narodov/macievskij_igor_ vladimirovich (accessed: 15 January 2019).

7. Lisovoj Vladimir Ivanovich. The Russian State Specialized Academy of Arts. Available at: http:// rgsai.ru/ob-akademii/pedagogicheskij-sostav?id=269 (accessed: 15 January 2019) (in Russian).

8. Kryazheva Irina Alekseevna. Moscow State Tchaikovsky Conservatory. Available at: http://www. mosconsv.ru/ru/person.aspx?id=8803 (accessed: 15 January 2019) (in Russian).

9. Sigida Svetlana Yur'evna. Moscow State Tchaikovsky Conservatory. Available at: http://www. mosconsv.ru/ru/person.aspx?id=8932 (accessed: 15 January 2019) (in Russian).

10. Dzhani-Zade Tamila Makhmudovna. Gnessin Russian Academy of Music. Available at: https:// gnesin-academy.ru/dzhani-zade-tamila-mahmudovna/ (accessed: 15 January 2019) (in Russian).

11. Lisovoj V. I. Istoriya muzyki $i$ sovremennaya muzykal'naya kultura. Meksika i Tsentral'naya America [The history of music and modern musical culture. Mexico and Central America]. 2nd edition. Moscow: Yurait Publ., 2019. 200 p. (in Russian).

12. Vasil'chenko Elena Viktorovna. RUDN University. Available at: http://www.rad.pfu.edu.ru/ veduschie-uchenye/zasluzhennye-deyateli-nauki-professora-rudn/vasilchenko-elena-viktorovna (accessed: 15 January 2019) (in Russian).

13. Alpatova A. S. Istoriya muzyki. Arkhaika v mirovoi muzykal'noi kul'ture [The history of music. The archaism in world musical culture]. 2nd edition. Moscow: Yurait Publ., 2019. 247 p. (in Russian).

14. Scientific and Art Center "World Music Cultures". Moscow State Tchaikovsky Conservatory. Available at: http://www.mosconsv.ru/ru/groups.aspx?id=124216 (accessed: 15 January 2019) (in Russian).

15. Nikolaeva Elena Vladimirovna. Moscow Pedagogical State University. Available at: http://mpgu.su/ staff/nikolaeva-elena-vladimirovna (accessed: 15 January 2019) (in Russian).

16. Nikolaeva E. V. Traditsionnaya muzykal'naya kul'tura narodov mira kak komponent vuzovskogo muzykal'no-pedagogicheskogo obrazovaniya [Traditional Musical Culture of Peoples of the World 
as a Component of the University Music-Pedagogical Education]. Vestnik kafedry UNESCO "Muzykal'noe iskusstvo i obrazovanie" = Bulletin of the UNESCO Chair "Musical Arts and Education”, 2018, no. 4, pp. 145-162 (in Russian, abstract in English).

17. Vasil'chenko E. V. Dialog zvukomuzykal'nykh traditsii v sisteme mirovykh tsivilizatsii [Dialogue between sound and musical traditions in the system of world civilizations]. Fenomen tvorcheskoi lichnosti v kul'ture. Fatyushchenkovskie chteniya [The Creative Individual in the Cultural Context: Readings in Memory of V. I. Fatyuschenko]. The Materials of the III International conference. Eds. A. V. Vashenko, M. D. Potapova. Moscow: MGU Publ., pp. 548-564 (in Russian).

18. Orlov G. Drevo muzyki [The Tree of Music]. Washington: H. A. Frager \& Co; St. Petersburg: Sovetsky kompozitor Publ., 1992. 403 p. (in Russian).

19. Mikhailov G. K. K probleme teorii muzykal'no-kul'turnoi traditsii [On the problem of the theory of the music and cultural traditions. Muzykal'nye traditsii stran Azii i Afriki [Musical traditions of Asia and Africa]: collection of scientific works. Moscow: MGDOLK named after P. I. Chaikovsky Publ., 1986, pp. 3-20 (in Russian).

20. Yunusova V. N. Tvorcheskii protsess $v$ klassicheskoi muzyke Vostoka [Creative process in classical music of the East]. Extended abstract of Doctoral dissertation (Arts). Moscow: MGDOLK named after P. I. Chaikovsky Publ., 1995. 37 p. (in Russian).

21. Matsievsky I. V. Narodnaya instrumental'naya muzyka kak fenomen kul'tury [Folk Instrumental Music as a Cultural Phenomenon]. Almaty: Daik-Press Publ., 2007. 520 p. (in Russian).

22. Gachev G. D. Kosmos-Psikho-Logos: Natsional'nye obrazy mira [Cosmo-Psycho-Logos: National Images of the World]. Moscow: Akademichesky proekt Publ., 2007. 511 p. (in Russian).

23. Vashchenko A. V. Sud Parisa: sravnitel'naya mifologiya v kul'ture i tsivilizatsii [The Judgement of Paris: comparative mythology in culture and civilization]. Moscow: FIYaR MGU Publ., 2008. 134 p. (in Russian).

24. Gavryushenko N. Tvorcheskie nachala i teoreticheskie osnovy kontseptsii G. A. Orlova [Creative beginnings and theoretical foundations of G. A. Orlov's conception]. Sravnitel'noe iskusstvoznanie XXI vek [Comparative Art Studies XXI century]. Issue 1: Nasledie Genrikha Orlova i aktual'nye problemy sovremennogo sravnitel'nogo iskusstvoznaniya [The heritage of Genry Orlov and actual problems of modern comparative art studies]: the collection of articles and materials. Part 1. Eds. O. V. Kolganova, I. V. Matsievsky. St. Petersburg: Russian Institute of Art History Publ., 2014, pp. 48-68 (in Russian).

25. Yunusova V. N., Alpatova A. S. Muzykal'nye kul'tury mira v nauchnoi i pedagogicheskoi deyatel'nosti G. K. Mikhailova (k 80-letiyu so dnya rozhdeniya) [World Musical Culture in Scientific and Pedagogical Activity of G. K. Mikhaylov (on occasion of his 80th birthday]. Muzykovedenie $=$ Musicology, 2018, no. 1, pp. 52-61 (in Russian).

26. Muzyka narodov mira: problemy izucheniya [Music of peoples of the world: problems of study]. Proceedings of International scientific conferences. Issue 1. Eds. V. N. Yunusova, A. V. Kharuto. Moscow: Moskovskaya konservatoriya Publ., 2008. 416 p. (in Russian).

27. Matsievsky I. V. V prostranstve muzyki [In the space of music]. St. Petersburg: Russian Institute of Art History Publ., 2011. Vol. 1. 206 p. (in Russian).

28. Tkachenko N. V., Ovchinnikova Yu. S. Psikhologo-pedagogicheskaya podgotovka polevogo issledovatelya: razvitie affektivnogo komponenta lichnosti sredstvami traditsionnoi muzyki narodov mira [Psychological preparation of a field researcher: development of affective component of personality by means of traditional music of peoples of the World]. Kontsept: nauchnometodicheskii elektronnyi zhurnal [Concept: Research and Methodological electronic journal], 2018, no. 6, pp. 78-90 (in Russian). 
29. Ovchinnikova Yu. S. Tradicionnye muzykal'nye instrumenty narodov mira kak dejatel'nostnoe sredstvo pedagogiki sinteza [Traditional Musical Instruments of Peoples of the World as Activity Means of Pedagogy of Synthesis]. Vestnik kafedry UNESCO "Muzykal'noe iskusstvo $i$ obrazovanie" = Bulletin of the UNESCO Chair "Musical Arts and Education", 2015, no. 1 (9), pp. 11-24 (in Russian, abstract in English).

30. Ovchinnikova Yu. S. Traditsionnye pesni narodov mira kak deyatel'nostnoe sredstvo ponimayushchego soperezhivaniya drugoi kul'tury [Traditional Songs of Peoples of the World As Activity Approach to Co-Experiencing of Other Culture]. Vestnik kafedry UNESCO "Muzykal'noe iskusstvo i obrazovanie" = Bulletin of the UNESCO Chair "Musical Arts and Education", 2016, no. 4 (16), pp. 25-36 (in Russian, abstract in English).

31. Ovchinnikova Yu. S. Muzykal'noe skazitel'stvo v obrazovatel'noi praktike: sushchnost', soderzhanie, usloviya i formy organizatsii [Musical Storytelling in Educational Practice: the Nature, the Contents, Conditions and Forms of Organization]. Vestnik kafedry UNESCO "Muzykal'noe iskusstvo i obrazovanie" = Bulletin of the UNESCO Chair "Musical Arts and Education”, 2017, no. 2 (18), pp. 135-149 (in Russian, abstract in English).

32. Ovchinnikova Yu. S. Tvorcheskaya rabota s intoniruemym perezhivaniem kak sredstvo razvitiya muzykal'noi kul'tury lichnosti [Creative Work with Intoning Experiencing as Means of Personal Musical Culture Development]. Vestnik kafedry UNESCO "Muzykal'noe iskusstvo i obrazovanie" = Bulletin of the UNESCO Chair "Musical Arts and Education", 2018, no. 3 (23), pp. 68-82 (in Russian, abstract in English).

33. Ovchinnikova Yu. S. Samopoznanie kak neobkhodimyi komponent muzykal'nogo obrazovaniya: muzykal'nye kategorii kak metafory vnutrennei zhizni cheloveka [Self-Discovery as Necessary Component of Musical Study Education: Musical Categories as Metaphors of Interior Life of a Person]. Vestnik kafedry UNESCO "Muzykal'noe iskusstvo i obrazovanie" = Bulletin of the UNESCO Chair "Musical Arts and Education”, 2018, no. 1 (21), pp. 38-49 (in Russian, abstract in English).

34. Ovchinnikova Yu. S. Pedagogicheskie osnovy razvitiya odarennosti sredstvami traditsionnoi muzyki narodov mira [Pedagogical Foundations of Giftedness Development by Means of Traditional Music of Peoples of the World]. Problemy sovremennoj nauki $i$ obrazovaniya = Problems of Modern Science and Education, 2018, no. 4, pp. 187-204 (in Russian, abstract in English).

35. Vasilyuk F. E. Psikhologiya perezhivaniya [Plsychology of experiencing]. Moscow: MGU Publ., 1984. 240 p. (in Russian).

Submitted 06.03.2019; revised 15.03.2019.

About the author:

Yulia S. Ovchinnikova, Associate Professor at the Department of Comparative Literature and Culture, Faculty of Foreign Languages and Area Studies, Lomonosov Moscow State University (Leninskie Gory, 1, Moscow, Russian Federation, 119991), PhD Cultural Studies, julia.barkova@gmail.com

The author has read and approved the final manuscript. 


\section{ТЕХНОЛОГИЧЕСКИЕ ОРИЕНТИРЫ}

МОНИТОРИНГА ГОТОВНОСТИ СТУДЕНТОВ-

МУЗЫКАНТОВ К ХУДОЖЕСТВЕННО-

ИНТЕРПРЕТАЦИОННОЙ ДЕЯТЕЛЬНОСТИ

\section{И. Е. Молоствова,}

Мордовский государственный педагогический институт имени М. Е. Евсевьева, г. Саранск, Республика Мордовия, Российская Федерация, 430007

Аннотация. B статье характеризуются требования, предъявляельле $\kappa$ человеку нового врелени, выражаюшиеся в необходилости его личностного салоразвития, полноценного раскрытия творческого потенииала. Определяется специфбка пробессиональной деятельности педагога-лузыканта как субьекта культурь, способного к установлению с обучающилися взаилодействия духовного уровня, которое базируется на актуализаиии творческого салосознания всех субъектов образовательного процесса. Автор расслатривает возложность технологизаиии процесса овладения педагогол-музыкантол художественно-интерпретационной деятельностью как необходилой составляющей его профбессиональной подготовки, начиная с разработки диагностики успешности овладения ею. С этой иелью вводится понятие «художественно-интерпретаиионная колпетентность педагога-лузыкантал и определяются этапь овладения ею: мотивационно-ориентировочный, процессуально-деятельностный и результативно-корректировочный. В статье предлагается развёрнутая характеристика этих этапов с точки зрения содержания и диагностики достижения соответствующего уровня. В соответствии с этил для диагностики процесса форлирования художественно-интерпретационной колпетентности автор предлагает уровневый принцип диагностики и прилерную систему заданий, выявляющих знания и уления, характеризуелье как стандартные, ключевые или ведущие.

Ключевые слова: гуманитарные иенности общества и культуры, художественная интерпретаиия, образовательнье технологии, культуросоответственное лузыкальное образование, творческий потенииал обучаюшихся.

Благодарности: Автор выражает глубокую благодарность заведующелу кафбедрой методологии и технологий педагогики музыкального образования Московского педагогического государственного университета, доктору педагогических наук, профбессору Эдуарду Борисовичу 
Абдуллину за постоянное внилание и заинтересованную поддержку в научно-исследовательской деятельности. Искренняя признательность - главнолу редактору журнала "Музыкальное искусство и образованиен, доктору педагогических наук, профбессору Елене Владилировне Николаевой за неоценилую полощь и важные советы в процессе подготовки статьи к публикации.

Для цитирования: Молоствова И. Е. Технологические ориентиры мониторинга готовности студентов-музыкантов к художественно-интерпретационной деятельности // Музыкальное искусство и образование. 2019. T. 7. № 1. C. 60-77.

\title{
TECHNOLOGICAL TERMS OF MONITORING THE READINESS OF MUSICIAN STUDENTS FOR ARTISTIC-INTERPRETATIONAL ACTIVITIES
}

\section{Irina Ye. Molostvova,}

Mordovian State Pedagogical Institute named after M. E. Evsevyev, Saransk, Republic of Mordovia, Russian Federation, 430007

\begin{abstract}
The article describes the requirements for a man of the new time, expressed in the need for his personal self-development, the full disclosure of creative potential. The specificity of the professional activity of a teachermusician as a subject of culture capable of establishing a spiritual level interaction with students is determined, which is based on the actualization of the creative self-consciousness of all subjects of the educational process. The author considers the possibility of the technologization of the process of mastering the teacher-musician artistic and interpretative activities as a necessary component of his professional training, starting with the development of diagnostics of the success of mastering it. For this purpose, the concept of "artistic and interpretational competence of a teacher-musician" is introduced, and the stages of mastering it are defined: motivational-indicative, proceduralactivity-related, and effective-corrective. The article proposes a detailed description of these stages in terms of content and diagnosis of the achievement of the appropriate level. In accordance with this, to diagnose the process of forming artistic and interpretative competence, the author proposes a level principle of diagnosis and an exemplary system of tasks that reveal knowledge and skills that are characterized as standard, key or leading.
\end{abstract}

Keywords: humanitarian values of society and culture, artistic interpretation, educational technologies, cultural and appropriate musical education, creative potential of students. 
Acknowledgements: The author is deeply grateful to the head of the Department of Methodology and Technology of Pedagogy of Music Education of the Moscow Pedagogical State University, Doctor of Pedagogical Sciences, Professor Edward B. Abdullin for his constant attention and interested support in research activities. Sincere appreciation to the Editorin-Chief of the bulletin "Musical Art and Education", Doctor of Pedagogical Sciences, Professor Elena V. Nikolaeva for invaluable help and important advice in the process of preparing an article for publication.

For citation: Molostvova I. Ye. Technological terms of monitoring the readiness of musician students for artistic-interpretational activities. Muzykal'noe iskusstvo $i$ obrazovanie = Musical Art and Education, 2019, vol. 7, no. 1, pp. 60-77.

\section{Проблема взаимодействия} художественного и технологического

\section{в профессиональной деятельности} педагога-музыканта

Цели и задачи современного профессионального образования ясно очерчивают необходимость формирования личности, готовой к саморазвитию, самообучению и самовоспитанию. Как никогда важными стали проблемы поиска путей актуализации учебной сало-деятельности, базирующейся на приоритете высоких гуманистических идеалов - свободы, плюрализма, радости творения. Последние отнюдь не предполагают анархию в процессе обучения. Напротив, ещё более важными становятся качества личности, связанные с самоорганизацией, рефрлекией и самооценкой. Следовательно, образование должно вооружить профессионала инструментами и механизмами автономного, но неконфрликтного бытия в постоянно эволюционирующем социокультурном пространстве. А значит, он должен обладать необходимыми для него технологиями осуществления той или иной деятельности, объективно обеспечивающими задан- ный результат, и одновременно системой диагностики осуществления процесса и его результата.

Для профессионального образования педагога эти тенденции ещё более актуальны. Педагог имеет дело с будущим; его деятельность связана со становлением человека, который через 5-10 лет станет активной единицей общества. А значит, ему необходимо стратегическое мышление, умение прогнозировать результат, актуальный для грядущего времени, предполагая этапы корректировки в соответствии с изменяющимися условиями.

В современном информационном мире непрерывно обновляются знания. Чтобы быть конкурентоспособным преподавателем, педагогу следует постоянно осваивать новые знания, сохраняя адекватный уровень профрессиональной компетентности, а следовательно, осуществлять диагностику этого соответствия и впоследствии управлять собственным обучением. Таким образом, обусловлена важность овладения приёмами самодиагностики и управления саморазвитием. При этом сложно переоценить роль принципа технологичности обучения, позволяющего правильно организовать 
вышеназванные процессы, способствуя одновременно максимальной реализации потенциала человека.

Вопрос о возможности взаимодействия искусства и технологии в процессе обучения искусству был поставлен ещё в прошлом веке. Однако до настоящего времени он остаётся в числе наиболее обойдённых вниманием из-за спорности обстоятельств этого взаимодействия. Вместе с тем В. Г. Маранцман заявляет о том, что если «гармония искусства предполагает некоторую упорядоченносты,, то и «общение с искусством требует соблюдения известных правил, открывающих засовы тяжких врат и дающих простор воображению читателя, зрителя, слушателя, личностной оценке художественного произведения» [1, с. 91]. Можно считать методологически важными следующие его слова: «Программа общения с искусством может быть представлена в виде цикла операций, каждая из которых имеет конкретную цель. Совокупность этих операций рождает интерпретацию художественного произведения» [Там же]. Следовательно, необходимо продумать названную деятельность с точки зрения её технологии.

Исследователь А. С. Мигунов, рассматривая проблему соотнесения технологии и искусства, находит общее для них начало в символизации (как в производственной области, так и в гуманитарном знании и художественном творчестве), а также в алгоритмизации соответствующих процессов. Вместе с тем он указывает: «Желание понять и объяснить слагае- мые искусства, а значит, отыскать его алгоритм, всегда присутствовало в эстетике. И всегда оно наталкивалось на значительные трудности, связанные и с тайной рождения художественного замысла, и с не менее таинственным процессом воплощения такого замысла в произведении искусства» [2, с. 14]. Таким образом, актуальной остаётся дилемма между стремлением «поверить алгеброй гармонию» и непостижимостью художественного творчества. Решение данной проблемы, как всегда, находится «где-то посередине», в той небольшой области, где пересекаются эстетика, искусствоведение, психология, социология, культурология и даже точные науки во главе с математикой ${ }^{1}$.

В связи с изложенным интересно высказывание отечественного пианиста и педагога Г. Г. Нейгауза: «Раздумывая об искусстве и науке, об их взаимных связях и противоречиях, я почему-то пришёл к выводу, что математика и музыка находятся на крайних полюсах человеческого духа, что этими двумя антиподами ограничивается и определяется вся творческая духовная деятельность человека и что между нили размещается всё, что человечество создало в области науки и искусства» [4, с. 14].

\section{Технологический подход к диагностике художественно- интерпретационной компетентности педагога- музыканта}

Педагог-музыкант по характеру своей деятельности априори является

1 Ярким примером единения музыки и математики является идея Ю. Г. Кона, в которой вычисления плотности созвучий с помощью математических методов соотносятся с эстетической категорией диссонантности, тесно связанной с психологией восприятия гармонического движения [3]. 
субъектом культуры, то есть осуществляет функции не только потребления и хранения художественных ценностей, заложенных в произведениях музыкального искусства, но и преобразования и трансляции. Поэтому один из важных критериев качества музыкального образования - готовность студента-музыканта к реализации себя как профессионала в социокультурно значимой деятельности художественной интерпретации. Художественная интерпретация музыки определяется нами как творческая деятельность человека по созданию авторской трактовки культурных смыслов, заключённых в произведении музыкального искусства.

Художественная интерпретация музыки является для педагога-музыканта генеральной деятельностью, охватывающей эмоционально-чувственные и иррационально-интуитивные психические процессы, культурно-исторические и музыкально-теоретические знания, аналитические умения, творческие навыки. Она обеспечивается соответствующей специальной компетентностью. Художественно-интерпретационная компетентность педагога-музыканта - это профессиональное интегральное качество личности, охватывающее комплекс знаний, способов действия, определённых отношений с привлечением внешних ресурсов, проявляющееся в готовности на их основе трактовать концепты, отношения и ценности, заключённые в произведении музыкального искусства. Анализ литературы позволил нам выработать следующий комплекс специальных quasi-компетенщий, обеспечивающих овладение художественно-интерпретационной деятельностью:
1) готовность понимать и выражать сущность художественной интерпретации музыкального произведения и её значение в профессиональной деятельности педагога-музыканта;

2) готовность творчески использовать художественную интерпретацию при словесной и исполнительской трактовке музыкального произведения;

3) готовность осуществлять транслящию интерпретированных культурных смыслов музыкального произведения в профессиональной деятельности.

Проблематика разработки технологии мониторинга готовности студентов-музыкантов $к$ художественно-интерпретационной деятельности, необходимой в подготовке педагога-музыканта, обладает своей спецификой, связанной с приоритетом художественных принципов познания. Texнологичность предполагает наличие целесообразных шагов, этапов, приводящих $\mathrm{\kappa}$ достижению поставленной цели. Критериями их целесообразности являются иерархичность и преемственность. Инновационно-педагогический аспект рассматриваемой в статье технологии выражается в отведении значительного места творчеству педагога и учащихся, проявлению их индивидуальных позиций.

Наше понимание художественной интерпретации музыки как деятельности, соответственно, говорит о необходимости применения деятельностного подхода, позволяющего проектировать путь от общей идеи к точно описанным конкретным действиям. С этой позиции мы выделили три этапа:

1) мотивационно-ориентировочный; 
2) процессуально-деятельностный;

3) результативно-корректировочный, предполагающий реализацию итогов работы в заданной музыкально-коммуникативной ситуации и построение перспективы дальнейших педагогических действий.

На каждом этапе осуществляется диагностика его составляющих.

\section{Диагностика художественно- интерпретационной компетентности на мотивационно- ориентировочном этапе}

Определение готовности студентов-музыкантов к художественно-интерпретационной деятельности на мотивационно-ориентировочнол этапе предполагает выявление следующих аспектов:

- эстетические, музыковедческие, художественно-критические знания;

- способность к понятийно-логическому и художественно-образному мышлению, осуществлению их синтеза;

- владение логикой музыкально-языковой системы конкретной музыкальной культуры с характерной для неё семантикой;

- навыки музыкально-аналитической деятельности по познанию материальной и идеальной структур произведения;

- наличие достаточного музыкально-интонационного запаса;

- способность к ассоциативночувственной работе;

- навыки интуитивно-иррационального постижения музыкального содержания;

- слухомоторные способности, различные виды музыкального слуха.
Комплексная диагностика позволяет сделать выводы о полученном студентом опыте - жизненном, культурном, художественном, музыкальном. По нашему мнению, именно этот опыт должен стать в первую очередь объектом пристального внимания как одно из исходных начал успешности художественно-интерпретащионной деятельности. Опыт - сложное личностное образование, включающее в себя:

1) опыт эмоциональных впечатлений от музыки (то есть совокупность - большую или меньшую произведений, которые остаются значимыми для того или иного субъекта в течение достаточно длительного времени) - слушательский;

2) опыт осмысления произведения музыкального искусства как продукта культуры - ментальный;

3) опыт музыкально-исполнительской деятельности (непосредственная реализация собственных творческих поисков в звучании) - исполнительский;

4) опыт размышления о музыке - концептуальныци, или интерпретационньй.

Важные критерии выявления опыта связаны с тем, какой след оставило в душе человека произошедшее с ним:

- насколько этот след оказался глубок, ярок;

- как это сопряжено с другими впечатлениями, а также с их количеством;

- насколько это впечатление личностно-рефлексивно осмысленно и переработано субъектом.

Наряду с этим важна и своеобразная предуготовленность индивида

\footnotetext{
1 Здесь и далее орфография и пунктуация в ответах респондентов частично изменены.
} 
к впечатлению, особое (можно сказать, мифологизированное) видение мира, при котором каждое (казалось бы, неактуальное) явление жизни замечается и становится личностно значимым. Поэтому важно выявление глубины запечатлённого в эмоционально-чувственной форме образа, степени его детализации и долговременности. Критериями впечатлительности, согласно материалам психологической литературы, являются:

- целостность охвата явлений;

- глубина эмоциональных реакций;

- число ярких впечатлений жизни;

- наличие синтезирующего мышления;

- выявленные области источника положительных и отрицательных ассоциаций.

Таким образом, опыт выступает одним из важных условий художественной интерпретации, обеспечивая уникальность познания студентом-музыкантом тех или иных музыкальных явлений. Эта уникальность обусловлена личным отношением индивида к различным сторонам реального мира.

В соответствии с названными выше четырьмя сферами индивидуального опыта (слушательского, ментального, исполнительского, концептуального) процессуально-деятельностный этап включает в себя также продвижение студента-музыканта по четырём качественным уровням художественно-интерпретационной компетентности.

Первый - периептивный - уровень предполагает трактовку студентом отдельного музыкального произведения, взятого вне контекстных связей, при опоре на актуализацию его эмоционально-чувственной сcреры. При этом важна целостность постижения музыкальных явлений. Она предполагает наличие более или менее осмысленного художественного образа, желание его воплотить и собственно воплощение в индивидуализированной форме. В связи с этим важно предоставление свободы учащимся в выражении себя, понимании музыки, в раскрытии внутреннего творческого потенциала. При восприятии музыки актуализируется процесс наблюдения за явлениями искусства, а изучаемые произведения становятся предметом обсуждения и анализа, и далее - частью духовного мира будущего педагога-музыканта, его повседневной жизни. Поэтому ещё один критерий диагностики этого уровня - вовлечённость в культурную жизнь общества, выражаемая в мотивации к осуществлению художественной интерпретации как социально значимой деятельности.

Второй - аналитико-синтетический - уровень связан с постижением студентом музыкального произведения как продукта художественной культуры с позиции его принадлежности к отдельному музыкальному жанру, авторскому стилю при актуализации аналитических умений, базирующихся на знаниях о системе средств музыкального языка. Здесь актуализируются познавательные операции, связанные с анализом устройства художественной целостности произведения, овладением или изобретением своих собственных познавательных операций, поиском и использованием необходимых знаний для углубления формирующегося интерпретаторско- 
го замысла. Критерий этого уровня овладение студентом операциональными навыками. Не утрачивающий связи с предыдущим, данный уровень предполагает детализацию сформированного в процессе музыкальной перцепции обобщённого образа в аналитических выводах.

Третий - художественно-творческий - уровень предполагает познание студентом музыкального произведения в контексте художественного направления, творческой школы, эпохи с использованием аналитикосинтетических умений, что воплощается в реализации познанного в собственной исполнительской редакции.

Четвёртый - концептуальный уровень связан с выявлением идейнообразного содержания музыкального произведения в соотнесении с современной интерпретатору культурой на основе сложившейся у него картины мира. Высший уровень художественно-интерпретационной компетентности направлен на становление музыканта-художника, музыканта-мыслителя. Здесь важнейшим критерием выступает концептуальность деятельности музыканта, проявление им собственного максимально уникального, творческого проявления мировоззренческого начала.

На каждом из уровней актуализируются соответствующие знания и умения - стандартные, ключевые и ведущие, необходимые для успешного освоения конкретного уровня. Стандартные связаны со способностью решать типовые для данного вида деятельности задачи. $\mathrm{K}$ таковым относятся знания и умения, получаемые обучающимися в традиционных музыкальных дисциплинах. Они являются необходимой базой лю- бой музыкальной деятельности, опирающейся в своём освоении на комплекс музыкальных способностей. Ключевые знания и умения выражаются в способности решать инновационные задачи, поскольку каждое произведение ставит перед слушателем новые вопросы. Это обусловлено неповторимостью художественного образа, постижение которого выражается в уникальной трактовке. Ведущие знания и умения предполагают способность к созданию новых видов профессиональной деятельности. Они связываются с профрессиональнопредметной сферой. Так, например, педагог-музыкант адаптирует результаты художественной интерпретации музыки к определённым социокультурным условиям.

\section{Система уровневых заданий на процессуально-деятельностном этапе диагностики художественно- интерпретационной компетентности}

Для разработки диагностики процесса формирования художественно-интерпретационной компетентности нами выбрана уровневая система заданий, исходящая из уровневой же модели формирования названной компетентности и являющаяся одной из актуальных педагогических идей современного гуманитарно ориентированного образования. Выполнение заданий требует интонационно-художественного прочтения музыки, направленного на поиск художественной идеи произведения и апеллирующего к личностному ассоциативно-чувственному общему и музыкальному опыту студента-музыканта, стимулирующего его самостоятельность, творческую ини- 
циативу при работе с музыкальным материалом.

Важными фракторами успешности художественной интерпретации музыки являются:

- целостное восприятие музыкального произведения, предшествующее непосредственной интерпретации;

- опора на знания о музыкально-языковых формах (музыкальных знаках), служащих проводниками художественного смысла и побудителями ассоциативной деятельности познающего;

- сорормированность навыков распознавания элементов музыкальной речи;

- трактовка воспринятых элементов музыкальной речи при обязательной контекстности их художественного значения (контексты эпохи, жанра и стиля, художественной коммуникации изучаемого произведения, музыкально-речевого фрункционирования конкретного элемента музыкального текста и его культурно-исторической трансформации).

Задания предполагают тесное взаимодействие художественно-образного и рационально-логического мышления. Поэтому важным условием их выполнения является словесная аргументация (в письменной форме) принятого интерпретаторского решения. Студентам-музыкантам предоставляется выбор формы письменной работы: очерк, текст беседы или лекции, критический отзыв, изложение впечатлений от прослушанной музыки, сказка или история мифологического характера, аналитический разбор, небольшое эссе и т. д. Написанные тексты озвучиваются и впоследствии коллективно обсуждаются. Важный момент такого обучения - диалоговый характер взаимодействия преподавателя и обучающихся. В таком случае будущий педагог-музыкант воспринимает себя в качестве субъекта образовательного процесса, в котором он вступает на уровень межличностных, coтруднических отношений с преподавателем и другими учащимися. В результате этого осуществляется личностный рост всех участников.

В плане реализации данных позиций представляется интересным предложение В. П. Рябцева об использовании в образовательном процессе культурных сценариев. Исследователь рассматривает их как форму реализации культурологического подхода к профрессионально-педагогическому образованию, представляющую собой «общий план, очерчивающий общие контуры профессионального поведения в культурном контексте», на основе которых создаются «индивидуальные сценарии - индивидуальные траектории образования» [5, c. 210]. В этом случае реализуется контекстное обучение (А. А. Вербицкий) [6], предполагающее моделирование предметного и социального содержания усваиваемой профессиональной деятельности с помощью системы различных форм, методов и средств обучения и опирающееся на три основных источника: 1) предметный и социальный контекст; 2) деятельностную теорию, 3) формы и методы активного обучения.

В целом задания позволяют выявить уровень приобретённых навыков вербализации собственной точки зрения. При этом актуализируется внутренний мир личности обучающегося, устанавливается органическая взаимосвязь между выводами о произведении логико-аналитического 
характера и художественной рефлексией, опирающейся на индивидуальный общекультурный, художественный и исполнительский опыт. Содержание заданий в наиболее общих чертах отражает этапы музыкальнопознавательного процесса (от наиболее обобщённого восприятия через выявление значимых элементов музыкальной речи к осознанию художественного мира произведения):

1. Эмоциональное содержание музыки.

2. Жанровая основа музыки.

3. Стилевая основа музыки.

4. Художественно-образная и идейная концепция музыкального произведения.

Алгоритмизированность заданий выражается в конкретной формулировке этапов их выполнения, последовательность которых позволяет достичь заданной определённым компетентностным уровнем степени понимания музыки.

Задание I. Элоциональное содержание музыки

(периептивный уровень

художественно-интерпретаиионной

колпетентности музыканта)

Цель: создание эмоционально-образной характеристики музыкального произведения.

Результат: словесный ряд (или словосочетания), последовательно отражающий эмоции, чувства, переживания, ассоциации, вызванные музыкой.

Методическое обеспечение ${ }^{1}$ :

- словарь эстетических эмоций [7];

- словарь прилагательных, связанных с характеристикой разных типов движения;
- словарь жестов [8];

- список цветов;

- список геометрических форм;

- словарь архетипов [9].

Алгоритм:

1. Дайте эмоционально-образную характеристику прослушанной музыки, выразив её в цепочке слов или словосочетаний (с использованием вышеназванных словарей).

2. Опишите собственные ассоциации и представления, возникшие в ходе прослушивания данного произведения.

3. Определите ведущие смысловые элементы музыкального текста (музыкально-тематические образования) и охарактеризуйте их эмоционально-образное содержание, а также степень выразительного контраста.

4. Персонифицируйте ваши чувственные впечатления в архетипическом имени.

5. Выявите музыкально-выразительные средства (тема, регистр, лад, динамика, тембр) и определите их роль в организации художественного смысла конкретного музыкально-тематического образования.

6. Сравните произведение с известными вам аналогичными по содержанию произведениями живописи, литературы, других видов искусства; сделайте выводы о сходстве и различии эмоџионально-выразительных качеств.

7. Сопоставьте музыкальные выразительные средства со средствами других искусств; определите, можно ли провести между ними какие-либо аналогии (ответ обоснуйте).

8. Составьте небольшой словесный парафраз, раскрывающий эмо-

\footnotetext{
1 Данные методические материалы могут использоваться и на последующих уровнях.
} 
ционально-образное содержание музыки.

9. Исполните произведение (фрагмент) в соответствии с выработанными представлениями о нём.

Задание II. Жанровая основа музыки (аналитико-селантический уровень художественно-интерпретационной колпетентности музыканта)

Цель: выявление музыкальноязыковой и жанровой основы музыкального произведения.

Результат: словесный аналитический текст.

Методическое обеспечение:

- словарь музыкальных жанров.

Алгоритм:

1. Определите жанровую основу произведения, выделив жанровый комплекс на основании предложенной таблицы жанров ${ }^{1}$.

2. Выявите жанровые музыкально-выразительные средства, определите их роль в создании художественного смысла.

3. Охарактеризуйте взаимосвязь образного содержания произведения и избранного композитором жанра (или жанров, если музыка основывается на нескольких).

4. Проведите анализ метроритмической организащии мелодии, выделив и охарактеризовав при этом элементы, типичные для данного жанра.

5. Проанализируйте характер взаимодействия данного жанра и мелодической линии, определите выразительное значение их соотнесения.

6. Охарактеризуйте жанровую специфику фрактуры.

7. Суммируйте все музыкальные средства, характерные для рассмат- риваемого жанра (жанровый комплекс), и определите типичность музыки для данного жанра.

8. Исполните произведение (фрагмент) в соответствии с выработанными представлениями о нём.

Задание III. Стилевая основа музыки (художественно-творческий уровень художественно-интерпретаиионной компетентности музыканта)

Цель: характеристика музыкального произведения в контексте художественного направления, творческой школы, эпохи создания.

Результат: текст, выражающий интерпретаторский замысел, исполнение музыкального произведения.

\section{Алгоритм:}

1. Выделите комплекс выразительных средств, характерных для данного авторского стиля (или стиля соответствующего художественного направления, нащиональной школы).

2. Определите склад музыки (тип фактуры), свяжите выводы с исторической эпохой, к которой принадлежит произведение.

3. Выявите стилевую специфику (ладово-интонационную, метроритмическую и синтаксическую) организации мелодии, её воздействие на выразительность и смысловое содержание музыки.

4. Сделайте общие выводы о структуре и фрункциональной принадлежности аккордов.

5. Сравните мелодику и гармонию пьесы и сделайте выводы о связанных с этим отличительных стилевых чертах произведения.

6. Раскройте драматургию музыкального произведения в мифологизированном «сюжете».

\footnotetext{
1 При выполнении задания испытуемым предъявляется таблица жанров.
} 
7. Охарактеризуйте взаимосвязь конкретного стиля (исторического, национального или авторского) и художественно-образного содержания пьесы; выводы свяжите с музыкально-исполнительскими задачами.

8. Исполните произведение (ррагмент) в соответствии с выработанными представлениями о нём.

\section{Задание IV. Художественно-образная и идейная кониепиии музыкального произведения (концептуальный уровень} художественно-интерпретационной колпетентности музьканта)

Цель: выявление концептуального содержания музыкального произведения в соотнесении с современной интерпретатору культурой.

Результат: творческая интерпретация музыкального произведения.

Алгоритм:

1. Охарактеризуйте связь содержания произведения с действительностью - конкретными жизненными явлениями или чувствами, эмоциями и мыслями человека.

2. Выявите степень обобщённости образа.

3. Определите наличие авторского отношения к отражаемым явлениям.

4. Выявите, в чём заключается индивидуализированность созданного композитором образа.

5. Опишите музыкальные выразительные средства, способствующие созданию художественного эффоекта.

6. Сдрормулируйте выводы относительно сделанной творческой находки композитора.

7. Раскройте драматургию музыкального произведения в мифологизированном «сюжете».
8. Определите культрную ценность произведения с позищии современности.

9. Исполните произведение (фрагмент) в соответствии с выработанными представлениями о нём.

Как видно из представленных заданий, их содержание нелокально: компоненты их переплетаются между собой, либо предвосхищая будущий уровень, либо синтезируя ранее использованные знания и навыки. Выполнение заданий включает в себя исполнительскую и словесную интерпретацию предложенных музыкальных произведений. Последовательность словесной и исполнительской интерпретаций определяется самим студентом. Важными критериями при этом являются: 1 - установление ораторского и исполнительского взаимодействия с аудиторией; 2 - адекватное моделирование ситуации непосредственного общения со слушателями; 3 - пройденный путь открьтия: музыкального содержания, творческого метода композитора, демонстрации собственной интерпретаторской позиции.

\section{Результативно-корректировочный этап диагностики}

На данном этапе осуществляется диагностика эфрфективности формирования художественно-интерпретационной компетентности, обусловленная спецификой и задачами каждого её отдельного уровня. Оценка результатов художественно-интерпретационной деятельности позволяет задавать приоритетные направления индивидуального развития отдельного студента по каждому предмету или предметному циклу (на основе анализа имеющихся и недостающих знаний и умений). Это выражается в следую- 
щих стадиях педагогического взаимодействия со студентами:

1. Анализ сфрормированного комплекса умений и навыков, соответствующих определённому уровню художественно-интерпретационной компетентности (в случае, если исследуются второй и более высокие уровни, оцениваются составляющие художественно-интерпретационной компетенции нижележащих уровней).

2. Разработка индивидуальных планов личностного и профессионального развития студентов и формирование мини-групп.

3. Планирование и реализация мероприятий по обучению и развитию как отдельного студента, так и учебной группы. Возможно также и стратегическое планирование по циклу дисциплин.

4. Оценка эффрективности реализации индивидуальных и групповых планов развития.

В числе целей рассматриваемого этапа - вовлечение студентов в музыкально-культурную жизнь общества, становление понимания музыки как обязательного элемента духовной ценности личности, привитие вкуса. Контрольные задания, направленные на осуществление исполнительской и словесной художественной интерпретации музыки, по своему содержанию связаны с методом ситуационных упражнений. Обучаемому предлагается решить поставленные задачи, учитывая контекст предполагаемой деятельности. Важно, что при этом формируется понимание студентами назначения осуществляемой художественно-интерпретационной деятельности, связанной с приобретаемой ими музыкально-педагогической профессией.
Исходя из положения о музыканте как о субъекте культуры, как об активном участнике социокультурных коммуникативных процессов, следует учитывать, что важным аспектом выполнения заданий является установление культуросообразного взаимодействия с аудиторией. Таким образом студент приобщается к миру художественных ценностей, заложенных в музыкальном произведении, к переживаниям и пониманию мира композитором, который в своём творении передаёт другим участникам художественной коммуникации собственное эмоционально-ценностное отношение к жизненным и природным явлениям, к разнообразным связям людей между собой. В результате актуализируются такие профессионально важные качества будущего педагога-музыканта, как:

- умение эмоционально заряжать собственным исполнением музыки слушателей, доносить до них художественную идею произведения и своё понимание её;

- способность увлечь рассказом о музыке, давая ей личностную оценку, проявляя способность к свободному общению с аудиторией по поводу конкретного произведения.

Выполнение осуществляется с учётом конкретной музыкально-коммуникативной ситуации (подготовить и провести беседу, рассказать о музыкальном произведении, выступить с вводным словом к прослушиванию или разучиванию произведения, с аннотацией к самостоятельно исполняемой музыке, партитурой вопросов после прослушивания, разработать моноурок в общеобразовательной школе и т. п.). 
Студент может сам выбрать тип предполагаемой аудитории (академический салон, коллега по ансамблю, ученик, класс, друзья, родители учащихся), после чего осуществляет анализ возрастных и социокультурных особенностей предполагаемой аудитории, определяет наиболее эффрективную форму устного преподнесения конкретного материала (целый урок или его фррагмент, беседа, лекция, диалог, игра, массовые формы музыкально-просветительной работы), задачи (педагогические, просветительные или другие) и соответствующую художественную ценность отбираемого музыкального материала. Далее следуют осмысление обучающимся проблемы, постановка художественноинтерпретационных задач, поиск путей их решения (что обусловливается тем или иным социокультурным контекстом), а также переход к самостоятельному решению задачи.

Природные задатки и способности, сформированные умения и навыки, комплекс имеющихся у студентов знаний не являются исчерпывающими для полной и адекватной диагностики художественно-интерпретационной компетентности. Важнее те стороны внутреннего мира личности, которые позволяют человеку называть себя музыкантом, то есть социально и культурно значимой единицей человеческого сообщества, играющей роль хранителя и транслятора духовных ценностей, заложенных в произведениях музыкального искусства. В связи с этим необходима диагностика личностных показателей:

- активной музыкально-познавательной позиции (проявление отношения к музыке как к художественно-содержательному явлению, самостоятельности музыкально-познавательной деятельности);

- стремления к самореализации в музыкальной деятельности (ясное понимание своего места в музыкальной культуре, наличие и частота исполнительских и лекторско-просветительских выступлений, участие в жизни образовательного учреждения);

- отношения к художественной интерпретации как к средству реализации творческой индивидуальности музыканта.

Данные критерии определяются с помощью анкетирования. Целесообразно использование двух видов анкет. Первая анкета открытого типа направлена на выявление понимания студентами-музыкантами термина «интерпретация» и значения интерпретации в жизни и искусстве; осознания степени важности владения интерпретацией исполнителем, музыковедом, преподавателем, места интерпретации в обучении музыканта и его профессиональной деятельности, комплекса знаний, умений и навыков, необходимых для осуществления художественной интерпретации музыкального произведения.

Вторая анкета закрытого типа охватывает вопросы, связанные с выявлением роли и места интерпретации в целостной музыкальной деятельности реципиента, в частности:

- сколько времени в сутки в среднем посвящается музыкальной деятельности: какую часть времени музыкальных занятий (в процентном соотношении) занимают работа над репертуаром, изучаемым в исполнительском классе, чтение с листа произведений, выбранных по собственному желанию, различные фрормы творческого музицирования (подбор 
музыки или аккомпанемента к вокальной музыке, сочинение собственных композиций и пр.), чтение музыкальной популярной, научнопопулярной и специальной литературы, слушание музыки, выполнение различных упражнений, как исполнительских, так и связанных с освоением музыкальной теории, профессиональное взаимодействие с коллегами, сокурсниками и др.;

- какой из видов музыкальной деятельности доставляет наибольшее удовольствие;

- что даёт занятие излюбленной музыкальной деятельностью (новые впечатления, возможность обогатить свою жизнь, развиваться благодаря более широким и глубоким знаниям о музыкальном искусстве, целенаправленное собственное музыкально-профессиональное развитие, возможность глубже познать суть музыкальных явлений, совершенствовать профрессиональные навыки и умения, помогающие решать различные задачи в реальной практической деятельности, открывать что-то новое);

- к чему проявляется большее стремление (к художественному взаимодействию $\mathrm{c}$ другими людьми в рамках коллективной музыкальной деятельности, к публичной демонстрации своих достижений, к собственному развитию, выражающемуся в какой-либо публичной музыкальной деятельности;

- какой мотив наиболее весом в плане музыкальной самореализации (публичный успех, повышение сощиального статуса, перспектива быть лучшим среди своих коллег, сокурсников, признание и одобрение результатов работы, ответственность за качество выполняемой деятельно- сти, возможность творческого, профессионального роста, возможность художественного межличностного контакта).

Специфика художественной интерпретации музыки как творческой деятельности, направленной на дальнейшую социокультурную реализацию, обусловливает сложность её оценки. Традиционная 5-балльная система не позволяет объективно оценить качество выполнения задания. Представляется целесообразной экспертная оценка по 10-балльной шкале. В учебных целях оценивание осуществляется всеми участниками коммуникативного процесса (членами учебной группы) с последующим выведением среднего балла по предлагаемым критериям:

1) личностное раскрытие содержания музыкального произведения;

2) степень полноты постижения авторского замысла (знание творческих приоритетов композитора, художественных ориентиров его деятельности этого периода и др.);

3) артистизм в донесении до публики сделанных выводов, их соответствие выбору предполагаемой аудитории;

4) уравновешенное сочетание познавательного и художественно-эстетического аспектов предъявленного материала;

5) детализированность интерпретаторской аргументации, наличие связи между явлениями музыки и личными впечатлениями выступающего;

6) адекватность словесной характеристики музыки и её исполнения;

7) успешность коммуникативного взаимодействия, проявляющегося 
в художественном эффректе, положительном отклике аудитории.

Оценочные критерии включают в себя определение социокультурной эфрфективности (результативности) и степень уникально-творческого подхода к созданию и реализации интерпретаторского замысла. При этом, конечно же, учитывается и степень адекватности музыкальному произведению осуществленных интерпретаторских усилий.

\section{Заключение}

Таким образом, диагностические процедуры со специально разработанными критериями, показателями и инструментарием измерения результатов деятельности могут быть технологизированы. Рассмотренная этапность мониторинга реализации формирования художественно-интерпретационной компетентности обладает сквозным характером. Это способствует эфрфективному освоению названных компетенций, а следовательно, создаёт предпосылки успешного профессионального роста педагога-музыканта. Изложенное в статье позволяет выделить следующие технологические ориентиры мониторинга эффективности формирования художественно-интерпретационной компетентности будущего педагогамузыканта:

- сочетаемость и взаимодополняемость её уровней;

- наличие стандартизированных заданий, выполняемых по заданному алгоритму;

- учёт всех ранее освоенных уровней, благодаря чему возникает системность освоения компетентности;

- на всех уровнях освоения компетентности все задания оценивают- ся по одной системе критериев, что позволяет сопоставлять результаты.

Систематичность мониторинга невозможна без перманентного консультирования студентов. Она помогает им правильно оценить свои способности, умения и навыки, разработать стратегию личностного развития и обеспечить необходимые для этого условия. В результате самостоятельно осмысливаются следующие проблемы:

- отсутствие определённой составляющей художественно-интерпретационной компетентности того или иного уровня;

- постановка задач собственного развития;

- выбор учебной деятельности, наиболее эфрфективной для решения поставленной задачи.

Для практической реализации системы мониторинга эфрфективности формирования художественноинтерпретационной компетентности необходимы соответствующие коррективы в методических документах. Они должны содержать набор составляющих художественно-интерпретационной компетентности.

В этом плане целесообразно введение интерпретационного практикума, который будет иметь отдельный оценочный критерий, учитываемый при отчётности наряду с теоретическими знаниями и частнопрактическими умениями. Это позволит сбалансировать образовательный и профессиональный аспекты подготовки, органично соотнести фундаментальную и практическую составляющие процесса обучения, что обусловит взаимодействие обучения и практической профрессиональной деятельности педагога-музыканта в социуме. 


\section{БИБЛИОГРАФИЯ}

1. Мараниман В. Г. Интерпретация художественного произведения как технология общения с искусством // Литература в школе. 1998. № 8. С. 91-98.

2. Мигунов А. С. Эстетика, искусство и современные гуманитарные технологии // Вестник Московского университета. Сер. 7. Философия. 2011. № 3. С. 3-25.

3. Кон Ю. Г. Об одном свойстве вертикали в атональной музыке // Музыка и современность. Вып. 7. М.: Музыка, 1971. С. 294-315.

4. Нейгауз Г. Г. Об искусстве фортепианной игры. М.: Музыка, 1988. 240 с.

5. Рябиев В. П. Теоретические основы культурологического подхода к профессиональному педагогическому образованию: дис. .... д-ра культурологии. 24.00.01. Краснодар, 2006. 288 с.

6. Вербицкий А. А. Контексты содержания образования. М.: Альфа, 2003. 80 с.

7. Ражников В. Г. Диалоги о музыкальной педагогике. М.: Классика-XXI, 2004. 136 с.

8. Флягина, Т. А. Проектирование человеко-компьютерного взаимодействия, основанного на жестах : Квалификационная работа на степень магистра наук по направлению «Математика, прикладная математика». Екатеринбург. 2010. URL: http://www.cv.imm.uran.ru/ uploads/f1/s/0/299/basic/353/487/m_1.0.1.pdf (дата обращения: 21.01.2019).

9. Марк М., Пирсон К. Герой и бунтарь. Создание бренда с помощью архетипов. СПб.: Питер, 2005. $336 \mathrm{c}$.

Поступила 05.02.2019; принята к публикации 27.02.2019.

\section{Об ав торе:}

Молоствова Ирина Евгеньевна, доцент кафедры музыкального образования и методики преподавания музыки Мордовского государственного педагогического института имени М. Е. Евсевьева (ул. Студенческая, д. 11А, г. Саранск, Республика Мордовия, 430007), кандидат педагогических наук, доцент, mie7@rambler.ru

Автором прочитан и одобрен окончательный вариант рукописи.

\section{REFERENCES}

1. Marancman V. G. Interpretaciya hudozhestvennogo proizvedeniya kak tekhnologiya obshcheniya $\mathrm{s}$ iskusstvom [Interpretation of a work of art as a technology to communicate with art]. Literature in school, 1998, no. 8, pp. 91-98 (in Russian, abstract in English).

2. Migunov A. S. Estetika, iskusstvo i sovremennye gumanitarnye tekhnologii [Aesthetics, art and modern humanities]. Vestnik Moskovskogo universiteta $=$ Moscow University Bulletin. Series 7. Philosophy, 2011, no. 3, pp. 3-25 (in Russian, abstract in English).

3. Kon Yu. G. Ob odnom svojstve vertikali v atonal'noj muzyke [On one property of vertical in atonal music]. Muzyka i sovremennost' [Music and Modernity]. Issue 7. Moscow: Music Publ., 1971, pp. 294-315 (in Russian).

4. Nejgauz G. G. Ob iskusstve fortepiannoj igry [On the art of piano playing]. Moscow: Music Publ., 1988. 240 p. (in Russian).

5. Ryabtsev V. P. Teoreticheskie osnovy kul'turologicheskogo podhoda k professional'nomu pedagogicheskomu obrazovaniyu [Theoretical foundations of the culturological approach 
to professional pedagogical education]. Doctoral dissertation (Culturology): 24.00.01. Krasnodar, 2006. 288 p. (in Russian).

6. Verbitsky A. A. Konteksty soderzhaniya obrazovaniya [Contexts of educational content]. Moscow: Alpha Publ., 2003. 80 p. (in Russian).

7. Razhnikov V. G. Dialogi o muzykal'noj pedagogike [Conversations about music pedagogy]. Moscow: Klassik-XXI Publ., 2004. 136 p. (in Russian).

8. Flyagina T. A. Proektirovanie cheloveko-komp'yuternogo vzaimodejstviya, osnovannogo na zhestah [Designing human-computer interaction based on gestures]. Ekaterinburg, 2010. Available at: http://www.cv.imm.uran.ru/uploads/f1/s/0/299/basic/353/487/m_1.0.1.pdf (accessed: 21.01.2019) (in Russian).

9. Mark M., Pirson K. Geroj i buntar'. Sozdanie brenda s pomoshch 'yu arhetipov [Hero and rebel. Creating a brand with archetypes]. St. Petersburg: Piter Publ., 2005. 336 p. (in Russian).

Submitted 05.02.2019; revised 27.02.2019.

About the author:

Irina Y. Molostvova, Associate Professor at the Department of Music Education and Methods of Teaching Music, Mordovia State Pedagogical Institute named after M. E. Evsevyev, Student Street, 11A, Saransk, Republic of Mordovia, 430007), PhD in Pedagogy, Associate Professor, mie7@rambler.ru

The author has read and approved the final manuscript. 


\section{К ИСТОРИИ ОТЕЧЕСТВЕННЫХ ПРОГРАММ ПО МУЗЫКОТЕРАПИИ: В. М. БЕХТЕРЕВ - МЕЖДИСЦИПЛИНАРНЫЙ ПОДХОД В НАУКЕ И ОБРАЗОВАНИИ}

Е. М. Орлова,

Московский государственный институт музыки имени А. Г. Шнитке, Москва, Российская Федерация, 123060

Аннотация. $B$ статье анализируются иенностные, организационные и научные основания подхода В. М. Бехтерева $\kappa$ вопросал, связанныли с изучениел влияния музыки на солатическую и психическую сфберы человека. Представлены: разносторонняя проблелатика изысканий в даннол направлении школь В. М. Бехтерева, характеризующая её научную програлмлу; историко-фбилосообские и теоретико-летодологические предпосылки для планирования исследований. Особый интерес представляют лилоизвестные архивные докуленты, связанные с созданиел специальной колиссии по изучению влияния музыки и с деятельностью Государственного института музыкального просвещения, входившего в структуру Психоневрологической акаделии, созданной В. М. Бехтеревыл. Предпринята попытка ослыслить личностный потенциал учёного в развитии отечественного лузыкально-терапевтического, музыкально-психологического и музыкально-педагогического знания в контексте современных проблел науки и образования. Показано, что вклад учёного в даннол направлении состоит: в постановке методологии этих исследований на материалистический ббундалент; в привлечении эксперилентальных методов исследования музыкального воздействия; в утверждении ил принципов колплексности и междисииплинарности исследований, предполагающих синтез естественнонаучных и социально-гуланитарных дисииплин с музыкознаниел; в отстаивании единства теории, эксперилента и живой практики, индивидуального подхода в вопросах изучения влияния музыки на человека в лечебнол и образовательнол контекстах.

Ключевые слова: В. М. Бехтерев, музькотерапия, междисииплинарный подход, исследования влияния музыки, музыкально-терапевтическое образование.

Благодарности: Работа выполнена при поддержке каббедры психологии Московского педагогического государственного университета 
(МПГУ). Автор благодарит за содействие адлинистрацию Центрального государственного исторического архива (ЦГИА) и Центрального государственного архива литературы и искусства (ЦГАЛИ) СанктПетербурга.

Для цитирования: Орлова $E . M$. К истории отечественных программ по музыкотерапии: В. М. Бехтерев - междисциплинарный подход в науке и образовании // Музыкальное искусство и образование. 2019. Т. 7. № 1. С. 78-94.

\title{
TO THE HISTORY OF THE NATIONAL PROGRAMMES OF MUSIC THERAPY: V. M. BEKHTEREV - A MULTIDISCIPLINARY APPROACH IN SCIENCE AND EDUCATION
}

\section{Ekaterina M. Orlova,}

Moscow State Institute of Music named after A. G. Schnittke, Moscow, Russian Federation, 123060

\begin{abstract}
The article analyzes the valuable, organizational and scientific approaches by V. M. Bekhterev to the issues related to the study of the influence of music on the somatic and mental sphere of man. The versatile problems of researches of school of the scientist in this direction characterizing its scientific programme, historical and philosophical and theoretical and methodological bases are presented. Of particular interest are the littleknown archival documents related to the creation of a special Commission to study the influence of music and the activities of the State Institute of music education, which was part of the Psychoneurological Academy established by V. M. Bekhterev. An attempt is made to comprehend the value of the personal potential of the scientist in the development of the domestic musical-therapeutic, musical-psychological and musical-pedagogical knowledge from the perspective of the present time, from the point of view of modern problems of science and education. It is shown that the contributions of the scientist in this direction are to direct methodology of these researches on the materialistic base, to attract experimental methods of research of musical influence, to involve the synthesis of natural science and social and humanitarian disciplines with musicology, to uphold the principles of complexity and interdisciplinary, unity of theory, experiment and practice, individual approach to the study of the influence of music on the person in medical and educational contexts.
\end{abstract}

Keywords: V. M. Bekhterev, music therapy, interdisciplinary approach, music influence research, music therapy education. 
Acknowledgements: The work was performed at the Department of Psychology of the Moscow State Pedagogical University. The author thanks the administration of the Central State Historical Archive and the Russian Central State Archive of Literature and Art of St. Petersburg for their assistance.

For citation: Orlova E. M. To the history of the national programmes of music therapy: V. M. Bekhterev - a multidisciplinary approach in science and education. Muzykal'noe iskusstvo $i$ obrazovanie = Musical Art and Education, 2019, vol. 7, no. 1, pp. 78-94.

\section{Обращение к трудам}

В. М. Бехтерева в контексте поиска научных оснований лечебного и воспитательного воздействия музыки на личность

Современная система образования, направленная на усвоение учащимися логико-теоретической составляющей знаний и концентрирующаяся на практико-прагматическом подходе, зачастую отводит достаточно скромное место духовно-нравственной компоненте образовательно-воспитательного процесса, занимающей прочное место в педагогике и психологии искусства. Вместе с тем педагогика искусства в целом и музыкального образования в частности на каждом историческом этапе по-новому, в актуальных координатах и описаниях строит обоснование особенностей взаимодействия человека с искусством, выделяя различные грани такого взаимодействия.

В традициях отечественного образования процесс передачи знаний, умений и навыков всегда рассматривался в неразрывной связи с формированием духовно-нравственных основ личности и представлялся как единое целое: невозможно обучать не воспитывая. Иногда воспитание искусством, музыкой берёт на себя функцию коррекции неблагополучных состояний тела и души. Поиску научных оснований такого воздействия на личность и воспитания музыкой посвящены многие страницы трудов передовых педагогов-музыкантов. При этом, в силу объективных обстоятельств, вклад виднейшего отечественного врача и исследователя В. М. Бехтерева в разработку научных оснований музыкального воздействия и музыкотерапии остаётся малоизученным.

Социально-экономические и политические процессы, происходившие в современном российском обществе в последние десятилетия, позволяют по-новому осмыслить и интегрировать имеющийся в истории отечественной науки опыт и указывают на необходимость дальнейшей разработки подходов к использованию возможностей музыкального искусства в коррекции нарушений здоровья и в воспитании полноценной личности, как и в совершенствовании общества.

Анализируя ценностные, организационные и научные основания подхода В. М. Бехтерева к вопросам, связанным с изучением влияния музыки на соматическую и психическую сфреры человека, автор обрати- 
лась к архивам учёного ${ }^{1}$, страницы которого, посвящённые мыслям и планам разработки данного направления в науке, ещё не были полноценно изучены исследователями и опубликованы.

\section{Памятные вехи организационно- новаторского пути учёного}

Владимир Михайлович Бехтерев (1857-1927) вошёл в историю многогранным учёным, организатором науки и просветителем. Создавая своё комплексное учение, В. М. Бехтерев обозначил актуальные вопросы преобразования человека, рассмотрения его как активного деятеля по отношению к окружающей действительности. Учёный не раз указывал на то, что «правильное развитие и здоровье личности является основой государственного благосостояния страны» [1, с. 111]. Одной из главных его целей было всестороннее познание человека и создание для этого основательного научного фундамента. Так, в 1907 году состоялось открытие Психоневрологического института. Со временем в структуре Психоневрологического института (с 1921 года Психоневрологической академии) получили импульс и поддержку для своего становления многие научные, учебные, лечебные и воспитательные учреждения. Знаменательным событием в 1907 году стало открытие Педологического института, для которого В. М. Бехтеревым были определены самые серьёзные задачи по всестороннему изучению психики ребёнка и воспитания его с самого рождения.
Для решения задач просвещения и подъёма уровня образования в обществе в 1917 году при Психоневрологическом институте был учреждён Государственный университет для народа. В его состав входили четыре отделения: медицинское, естественно-историческое, этико-гуманитарное и отделение искусства.

В 1918 году по инициативе учёного состоялось открытие Института по изучению мозга и психической деятельности. На протяжении своего творческого пути В. М. Бехтерев неоднократно становился инициатором и создателем клиник, лабораторий, фракультетов, обществ и журналов [2]. Как популяризатор науки он ставил задачу сделать доступным научное знание как можно большему числу людей. Особое значение учёный придавал созданию в стране Музея мозга выдающихся людей, считая, что он «должен быть живым учреждением научно-исследовательского и в то же время просветительского характера» [3, с. 1318].

Свои научные изыскания В. М. Бехтерев направлял не только на решение проблем больного человека. Его внимание было приковано и к задачам социальной адаптации здорового человека через приведение «в соответствие с требованиями здоровой жизни» его мыслей и поступков [4, с. 437]. В этом отношении и музыка рассматривалась им как средство, облагораживающее человеческую натуру, способное оказывать воспитательное и лечебное воздействие $[5 ; 6]$.

1 Центральный государственный исторический архив Санкт-Петербурга (ЦГИА) и Центральный государственный архив литературы и искусства Санкт-Петербурга (ЦГАЛИ). 


\section{Изучение влияния музыки на человека как одно из важных направлений исследований В. М. Бехтерева}

В своих работах В. М. Бехтерев рассматривал влияние музыки на индивида с точки зрения её практического, воспитательного и лечебного значения, ориентированного на повышение качества жизни человека. Мысли учёного по данному направлению не только сконцентрированы в отдельных публикациях, но и буквально рассыпаны по его обширному творческому наследию. Исследования различного влияния музыки на человека представлены в архивных рукописях В. М. Бехтерева: «О влиянии музыки на здоровье» [7], «О музыкальном неврозе» [8], «Музыка как причина тоски и обморочного состояния» [9].

Ценность исследований музыкального воздействия представлялась В. М. Бехтеревым в возможности рационального применения музыки в повседневной практике врача и педагога. Согласно его воззрениям, эстетическое влияние музыки на личность определяется как особенностями самой музыки, так и индивидуальным её восприятием, изменяющимся в различных условиях и зависящим от степени утомлённости и здоровья, от уровня развития эстетического вкуса и интеллекта, от возрастных и национальных особенностей, эмоций и состояний на момент прослушивания произведения, в связи с чем одна и та же музыка у разных лиц и в разных условиях способна производить неодинаковый (благоприятный или неблагоприятный) эффект. В этом В. М. Бехтерев видел сложность исследования музыкального воздействия и высказывался о необходимости создания специальной экспериментальной обстановки для получения наиболее точных результатов.

\section{О создании Комиссии по разработке мер к практической утилизации музыки как могущественного лечебного средства}

Взгляды В. М. Бехтерева на проблему музыкального воздействия это точка зрения нейрофизиолога, невропатолога, психиатра и психолога. В его понимании музыкальное искусство предстаёт средством комплексного воздействия (лечебного, воспитательного, гигиенического) на соматическую и психическую сферу человека. Конкретная форма осуществления В. М. Бехтеревым комплексного и междисциплинарного подхода к познанию влияния музыки на человека находит воплощение в его трудах и в задачах специально созданной им в 1913 году в СанктПетербурге Комиссии по изучению лечебного, воспитательного и гигиенического значения музыки. Её цели и задачи, на наш взгляд, представляли собой попытку организационного закрепления научной программы и привлечения внимания широкого круга специалистов в области нейронаук и музыкального искусства к научным исследованиям в данной сдере. Анализируя источники, найденные автором статьи в ходе архивной работы $[10 ; 11]$ (фото 1), удалось восстановить персональный состав Комиссии, куда вошли доктора Л. М. Пуссеп и С. Е. Михайлов, композитор и музыкальный критик М. М. Иванов, профрессор Пе- 


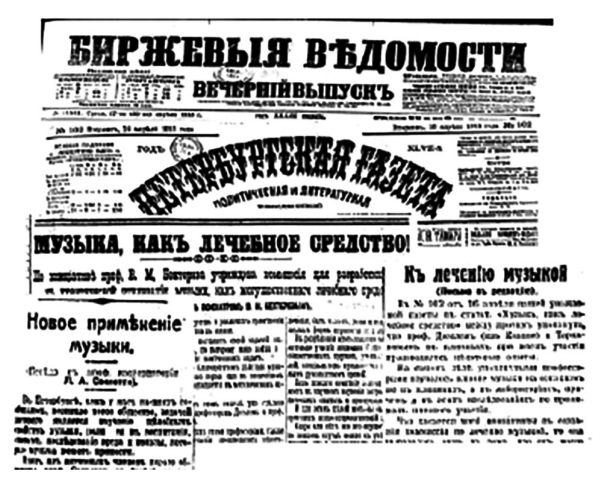

Фото 1. Публикации в «Петербургской газете» и «Биржевых ведомостях» (апрель 1913 г.) о создании В. М. Бехтеревым Комиссии по выяснению лечебного, воспитательного и гигиенического значения музыки

тербургской консерватории и Психоневрологического института Л. А. Саккетти, председатель Музыкальноисторического общества графра А. Д. Шереметева певица М. П. Тобук-Черкас. А. Д. Шереметев активно содействовал работе Психоневрологического института, возглавляя Попечительский комитет. Вместе со своим оркестром он принимал участие в исследованиях влияния музыки на организм человека, инициированных членами Комиссии (фото 2).

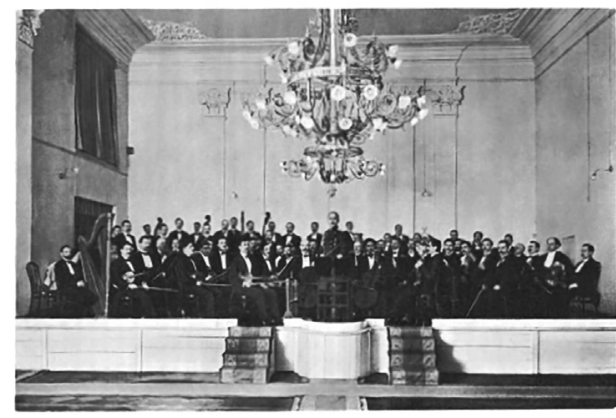

Фото 2. Оркестр графа А. Д. Шереметева Источник: Итоги музыкально-художественной деятельности графа А. Д. Шереметева:

11 янв. 1898 - 7 февр. 1910 г. / сост.

я. С. Кауфман. СПб.: тип. ред. период. изд. М-ва фин., 1910.
Заинтересованность и отзывчивость общественности по отношению к новости, опубликованной в прессе, о создании В. М. Бехтеревым Комиссии можно проследить по сохранившимся в ЦГИА (Центральном государственном историческом архиве) Санкт-Петербурга письмам, которые приходили к учёному в ответ на его выступления в газетах. Надо сказать, что почерк писавших местами практически не читаем. Однако в качестве иллюстрации к общественной дискуссии по данному вопросу, по сути, инициированной В. М. Бехтеревым, предлагаем рассмотреть одно из таких писем. Текст по возможности приведён в соответствие с нормами современного русского языка.

\section{Письло Марии Бобровой В. М. Бехтереву от 16 апреля 1913 года:} «Многоуважаемый Владимир Михайлович.

Статья «Музыка как лечебное средство» заставила меня поделиться с Вами следующим. Вы знали меня форменной истеричкой, с годами нервность увеличивалась. Наконец нашла исход своей мятущейся натуре - труд, свободный, интересный, но, не рассчитав своих сил, я изнемогала, падала духом, доходила до исступления в минуты отчаяния и [неразборчиво]. В это время около меня был человек, понимавший мою психику. Уговоры, успокоения ни к чему [не приводили] - я билась в истерических припадках. Тогда он садился к роялю и играл [для неё], пьесу “Warum". Успокоительные, нежные звуки как электрические токи вливались в мой больной мозг - мои мысли получали под ма- 
гическими звуками новые направления, и не было случая, чтобы мои истерзанные нервы не успокоились, и я засыпала совершенно умиротворённая и успокоенная. Простите, что занимаю Ваше драгоценное время, но, думаю, всякое подтверждение Вашему открытию не совсем бесполезно.

Преданная Вам Марія Боброва» [12].

Начавшаяся Первая мировая война внесла коррективы во многие сферы жизни России. О создании Комиссии и судьбе разработки влияния музыки В. М. Бехтерев пишет в своей статье «Вопросы, связанные с лечебным и гигиеническим значением музыки» (1916). Он отмечает, что «настоящая работа, приготовленная несколько лет тому назад, должна была служить вступительным словом к целому ряду исследований, намечавшихся в отношении применения музыки к медицине несколькими врачами и другими лицами, принимавшими участие в особой комиссии, избранной для этой цели Советом Психоневрологического института» [Там же, с. 105]. Несмотря на условия военного времени, учёный счёл необходимым опубликовать данную работу, осознавая её несомненную востребованность.

\section{О проекте специальной «музыкальной клиники»}

Организаторский потенщиал В. М. Бехтерева и понимание им необходимости консолидации научного сообщества вокруг многих проблем развивающейся нейронауки в России способствовали созданию условий как для формирования научной школы, так и для взаимодействия науки с обществом, популяризации научных знаний. В упомянутой выше статье «Музыка как лечебное средство», опубликованной в «Петербургской газете» от 16 апреля 1913 года, мы находим, по сути, уникальную в отношении нашего исследования информацию о том, что «неутомимый профр. - академик В. М. Бехтерев, учредив уже психоневрологический и алкогольный институты, собирается, по-видимому, приняться за сооружение специальной “музыкальной клиники”». Данный материал представляет собой интервью В. М. Бехтерева с неким С. Никитиным (вероятно, сотрудником газеты. - E. O.). Более подробно о планируемом устройстве клиники можно узнать из статьи члена созданной В. М. Бехтеревым Комиссии доктора С. Е. Михайлова «Применение музыки к лечению больных» [13].

Предполагалось, что «музыкальная клиника» (или, как сказано в статье, «особый Институт») с концертным залом, лабораториями и специальными комнатами - гипноториумами за счёт своего специального архитектурного решения сможет совмещать в себе научную и лечебную работу, связанную с применением музыки. И, вероятно, при более удачном стечении обстоятельств она могла бы стать первым в России специализированным научным учреждением, предназначенным для изучения влияния музыки на организм человека и использования её в составе психотерапевтического лечения.

Чтобы более отчётливо представить читателю масштаб проекта, позволим себе привести развёрнутую 
цитату из текста С. Е. Михайлова: «Требуется соединить обычный концертный зал с отдельными кабинетами, лабораториями, а в будущем и с палатами больных при посредстве проводников, которые во всякий момент могут быть разобщены, причём необходимо, чтобы с момента разобщения эти помещения оставались абсолютно друг от друга изолированными. При этом необходимо, чтобы означенный концертный зал имел достаточные размеры и хороший резонанс, то есть не был чем-то неестественным и особенным. Также необходимо, чтобы и в другие указанные помещения звук доходил непосредственно через воздушную передачу, не изменяя ни тембра своего, ни музыкальных нюансов. Всем этим требованиям удовлетворяет наш проект особого Института, который нуждается, конечно, в архитектурной разработке со стороны специалистов. В общих чертах он сводится к следующему: центральную часть здания занимает концертный зал обычного типа с достаточной эстрадой и органом. Этот зал занимает два этажа, по бокам размещаются ложи, имеется обычный партер. Из каждой ложи дверь ведёт в аванложи, которые соединены общим коридором, имеющим сообщение и с эстрадной частью здания, где располагаются артистические и др. комнаты и - с фойе, окружающим в виде подковы зрительный зал. Из фойе есть сообщение с заэстрадным помещением, полукруглым вестибюлем и улицей. Во 2-м этаже, соответственно аванложам и соединяющему их коридору, располагается ряд комнат, имеющих устройство наших гипноториумов.
То, что располагается над әстрадным помещением, может быть приспособлено под научные кабинеты и т. п. Часть же помещения во 2-м этаже, расположенная над фойе, - под лаборатории и пр. Следует указать, что все или часть вышеуказанных помещений легко могут быть превращены просто в постоянные палаты для больных. В стенах концертного зала, соответственно 2-му этажу, имеются особые ниши, которые в виде рупоров открываются широким концом, раструбом, в концертный зал, узким же, имеющим герметические затворы, - в гипноториумы, лаборатории и пр.

В концертном зале может состояться концерт, который слушает случайная публика как обычно. Однако концерт этот состоит из номеров, нужных для лечения данного состава больных в Институте. Больные находятся наверху в соответственных помещениях или могут быть вводимы изолированно от публики в аванложи. В гипноториумах, лабораториях и пр. герметические затворы ниш открываются для каждого помещения лишь к исполнению соответственного номера, нужного в целях лечения или исследования, в другое же время эти помещения вполне изолированы от звуков концертного зала.

Нам представляется, что помещение подобного устройства способно удовлетворять указанные выше надобности и в нём вполне может быть осуществлено как исследование влияния музыки на организм, так и лечение музыкой больных, комбинируя его с психотерапией» [13, c. 109-110]. 


\section{О музыкальных гипноториумах в учреждениях В. М. Бехтерева}

Специальные гипнотические комнаты, или гипноториумы, были и в Клиническом противоалкогольном институте, также созданном по инициативе В. М. Бехтерева. Гипноториумы Противоалкогольного института располагались под большим залом, в котором находился рояль. Об эфрфекте применения музыки в гипноториуме приведём строки С. Е. Михайлова: «Наши наблюдения показывают, что особенно благоприятное создавалось у больных душевное состояние для погружения в гипноз, когда в гипноториум вливались ласкающие слух и несколько печальные композиции Шопена и др., углублявшие настроение больных, созданное гипноториумом. Эти сеансы были особенно благоприятными и неизменно благотворными для больных. К сожалению, мы плохо владеем пером, чтобы передать на бумаге то необыкновенное и своеобразное настроение, которое способны создавать гипноториумы на больных и даже здоровых, особенно будучи заполненными нужными мотивами и гармониями» [Там же, с. 107-108].

Интересно отметить здесь, что, согласно Отчёту о деятельности Противоалкогольного института, «для музыкальных потребностей и развлечения больных в Институте имеется рояль фрабрики Blüthner'a и граммофон стоимостью в 400 рублей» [14, с. 44]. Таким образом, благодаря данной публикации, можно составить некоторое представление о планах В. М. Бехтерева и членов его Комиссии по научно-практической разработке вопросов, связанных с изучением влияния музыки на человека.

\section{Проекты В. М. Бехтерева} об интеграции лечебного и воспитательного воздействий музыки в специальных образовательных учреждениях

После революции 1917 года вопрос организации исследований влияния музыки на человека не оставался без внимания учёного. Приведём некоторые факты. Согласно Отчёту Института по изучению мозга и психической деятельности (от 15 июля 1919 года), Советом института были «выбраны также особые комиссии», среди которых значилась и Комиссия по разработке вопроса о воспитательном и лечебном применении музыки [15, с. 141].

Включённость музыкально-эстетического воспитания в жизнь учреждений В. М. Бехтерева показана и в Отчёте о деятельности Института по изучению мозга и психической деятельности (1919). В данном документе говорится об организации детских концертов при участии входившей в структуру этого института Школы музыкального просвещения под руководством профрессора Н. Д. Бернштейна и Художественно-музыкального детского сада Е. Н. Кашкадамовой. В концертах принимали участие дети и взрослые музыканты [Там же, с. 153-154].

Укажем и на исследования влияния ритмики на детей и взрослых с использованием естественного эксперимента, проводившиеся на протяжении двух лет по системе Э. ЖакаДалькроза психологом М. Я. Басовым в Лаборатории экспериментальной педагогики Института по изучению мозга и психической деятельности совместно с сотрудниками Петроградского института ритма. Они были ор- 
ганизованы «в целях более глубокого и всестороннего изучения ритмики, её психологического содержания и влияния её на индивидуальную личносты» [16, с. 488]. Работа в этом направлении была представлена в докладе, сделанном М. Я. Басовым на заседании Учёной конференщии Института 6 марта 1922 года [17].

\section{О Государственном институте музыкального просвещения, созданном при участии \\ В. М. Бехтерева}

Музыкально-психологическая и музыкотерапевтическая проблематика планировалась к разработке и в совместной научно-практической деятельности находящегося в структуре Психоневрологической академии государственного института музыкального просвещения (ГИМПа). Согласно архивным материалам, он был создан в октябре 1919 года в результате преобразования Четвёртой народной школы музыкального просвещения, основанной 6 октября 1918 года в Санкт-Петербурге (шко- ла музыкального просвещения просуществовала с 1918 по 1919 год). В качестве документального подтверждения укажем на постановление заседания Совета Психоневрологической академии, датируемое 1921 годом, о включении Государственного института музыкального просвещения в состав учреждений Психоневрологической академии. Приведём его фррагмент (фото 3) как пример междисциплинарного взаимодействия специалистов нейронаук и музыкального искусства: "Совет Психоневрологической академии постановил включить Государственный институт музыкального просвещения в состав учреждений Психоневрологической академии на одинаковых с другими учреждениями основаниях ввиду того, что Государственный институт музыкального просвещения с момента своего возникновения находится в объединении с Институтом по изучению мозга и психической деятельности, а также ввиду того, что включение в состав Психоневрологической акаде-

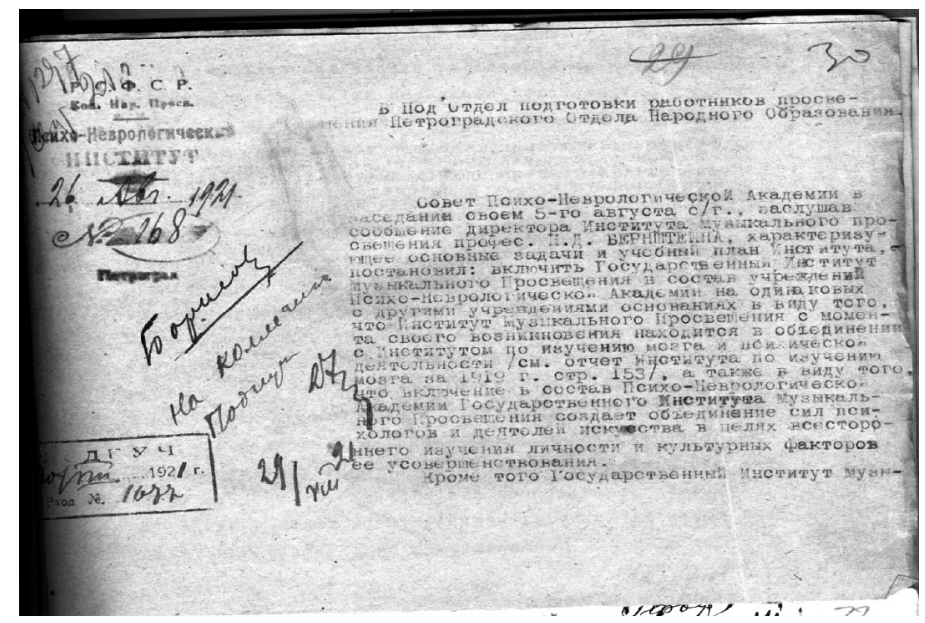

Фото 3. Фрагмент Постановления заседания Совета Психоневрологической академии о включении ГИМПа в состав учреждений Психоневрологической академии Источник: ЦГАЛИ СПб. Ф. 42. ОП. 1. Д. 15. Л. 30-30об. 
мии Государственного института музыкального просвещения создаёт объединение сил психологов и деятелей искусства в целях всестороннего изучения личности и культурных факторов её усовершенствования. Кроме того, Государственный институт музыкального просвещения является учреждением, крайне необходимым для ряда учреждений академии в отношении постановки в них эстетического музыкального воспитания, а также для практического использования музыки в других целях» [18].

В институте со стороны Психоневрологической академии преподавали: В. М. Бехтерев (рефолексология, художественная рефлексология); А. В. Гервер - ближайший коллега В. М. Бехтерева, врач, физиолог, психолог, доктор медицины, профессор (коллективная психология); В. М. Нарбут - врач, гистолог, физиолог, доктор медицины, профессор (психология, музыкальная психология); Д. В. Фельдберг - профессор, проректор ГИМПа (основы биологии, физиологии, анатомии); Я. С. Гурович - профессор Психоневрологического института (социология, введение в философию); С. О. Грузенберг - юрист, психолог и философ. А также известные деятели музыкального и драматического искусства: В. Г. Каратыгин - русский музыкальный критик, Г. К. Крыжицкий - русский режиссёр и театровед; М. Е. Климов - крупнейший русский советский хоровой дирижёр, В. В. Тиманова - русская советская пианистка и педагог; М. М. Петипа - русская артистка балета, дочь М. И. Петипа, и другие видные деятели искусств [19].
Важно отметить, что, согласно учебным планам Института, в образовательном курсе учебного заведения присутствовал предмет «Музыкальная психология» [20].

Позволим себе частично процитировать сохранившийся в архиве уникальный документ. В нём представлена программа совместной исследовательской работы Государственного института музыкального просвещения и Психоневрологической академии по широкому кругу музыкально-психологической и музыкотерапевтической проблематики: «Задачи исследовательского отдела как учёного [научного] учреждения заключаются в следующем: изучение и разработка вопросов музыкальнофилософского и музыкально-психологического характера; изыскание путей музыкально-лечебного воздействия как на психическую сферу человека, так и на физическую его природу; составление, применение на практике и распространение специального музыкально-лечебного репертуара; выработка методов музыкально-эстетического воспитания согласно возрасту, состоянию здоровья и социальному положению и применение его к воспитательным целям; точное определение методов для выявления степени музыкальной одарённости в психическом и физическом отношении; исследование физиологических и психологических основ музыкального труда и психофизиологических черт, характерных для музыкальных работников; изучение органических изменений, связанных с той или иной музыкальной профессией; исследование процесса музыкального творчества; определение израсходования музы- 
кальными работниками энергии и выяснение норм к её восстановлению» [21].

Совместная научно-учебная работа Психоневрологической академии и Государственного института музыкального просвещения представляет собой пример создания уникального союза специалистов из разных областей и конкретный пример реализации комплексного и междисциплинарного подхода к изучению особенностей влияния музыки и вопросов психологии творчества (художественной редрлексологии). Это находит своё отражение и в планах по осуществлению научно-практической деятельности, и в организационной структуре учреждений (фото 4). В отчётном документе, представляющем итоги трёхлетней деятельности ГИМПа за 1921 год, говорится о следующих совместных с Психоневрологической академией направлениях работы: «Научная деятельность Института музыкального просвещения выражалась в переработке учебного плана, с одной сторо- ны, вследствие полученного опыта за истекшее существование Института и благодаря тем заданиям, которые поставила более тесная связь с Психоневрологической академией. Особенное внимание было обращено на общеобразовательную часть для выработки правильного художественного миросозерцания и высокохудожественного эстетического вкуса и на подготовку тех основных проблем и тем, разработка которых должна вестись в Институте в ближайшее время. Таковыми являются: "Изучение влияния музыки на здоровый и больной организм”; "Применение музыки с лечебной целью”; "Изучение влияния музыки на труд и применение в производстве”.

В истекшем году заслушаны доклады:

- Академик В. М. Бехтерев: “Значение музыки в медицине”.

- Профрессор А. В. Гервер: "Влияние музыки на человеческий организм".

- Профрессор Д. В. Фельдберг: "Научные основы музыки”.

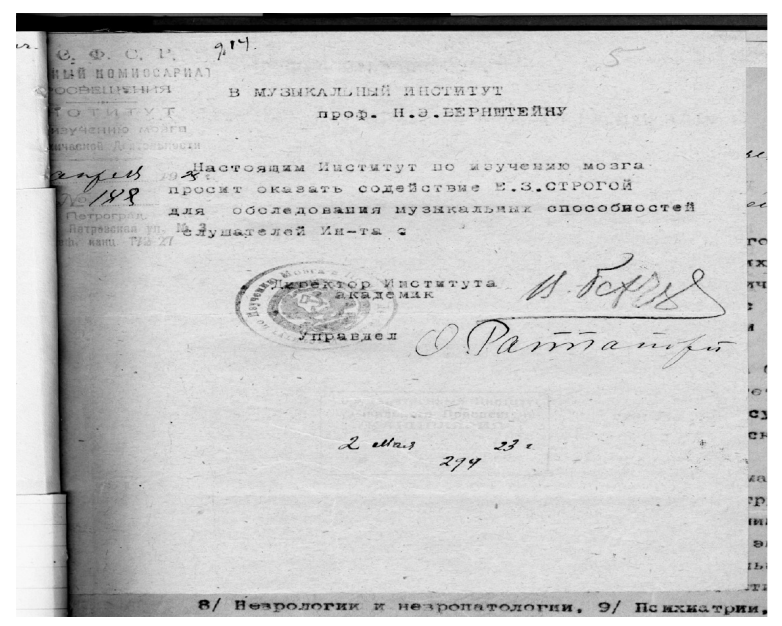

Фото 4. Письмо В. М. Бехтерева в Институт музыкального просвещения с просьбой оказать содействие для обследования музыкальных способностей слушателей Института (от 2 мая 1923 г.) Источник: ЦГАЛИ СПб. Ф. 42. Оп. 1. Д. 39. Л. 5. 
- Профрессор Н. Д. Бернштейн: "Значение музыки в эволюции культуры”.

- Профрессор П. А. Конский: "Музыка и психология".

- Профессор В. М. Нарбут: "Музыка и гипноз".

- Доктор Л. Л. Васильев: "Нормальная художественная идеология".

- Профессор В. Г. Каратыгин: “Творчество М. И. Глинки”.

Кроме того, лабораторные работы велись и ведутся доктором Ник. А. Пановым ("Обследование нервно-психического состояния начинающих деятелей музыкального искусства")» [22].

Интересно отметить, что руководством института поднимался вопрос о возможности отражения в дипломе выпускников их научной подготовки: «Правление ГИМПа считает необходимым, в отличие от консерватории, получить право присуждения дипломов с особым званием, кот. ясно подчёркивали бы музыкальноучёную подготовку» [23].

Существовал Государственный институт музыкального просвещения, согласно архивным документам, с октября 1919 по июль 1924 года. Научно-учебный проект института в том виде, в каком его себе, вероятно, представляли В. М. Бехтерев и Н. Д. Бернштейн, не реализовался в новых реалиях страны по ряду экономических, идеологических и иных причин. Согласно сохранившимся в архиве документам, можно лишь констатировать, как активно пыталось противостоять этим обстоятельствам руководство института: это и проблемы с финансированием; и необходимость следовать принципам унификации и типизации учебных планов и программ института, которые вымарывали его особую индивидуальность; и обший неблагоприятный фон настроений власти, сложившийся к тому моменту в отношении учреждений, созданных В. М. Бехтеревым. В итоге деятельность института была прекращена в результате его «слияния» с заурядными музыкальными техникумами [24]. Тем не менее этот исторический опыт может послужить достойным примером для организации деятельности в данной сфоре и на современном этапе.

\section{Заключение}

Основываясь на сказанном выше, важно отметить ряд существенных, на наш взгляд, обобщений о научном творчестве В. М. Бехтерева по данному направлению. Программность его подхода к исследованиям вообще и в данной сфере в частности предполагает интеграцию всех уровней научного познания, что явилось конституирующей основой для разработки В. М. Бехтеревым и его школой проблем влияния музыки на человека. Его материалистическое мировоззрение и практическая ориентированность как врача и исследователя становятся одной из главных движущих сил в разработке вопросов, связанных с изучением музыкального воздействия на человека. Комплексный и междисциплинарный подход учёного, не оставляющий без внимания возможности музыкального искусства как средства, облагораживающего человеческую личность, актуален и для современной научной картины мира, для решения актуальных социальных и психологических проблем современного общества. 
Взгляды В. М. Бехтерева на проблему влияния музыки на человека в своей совокупности представляют своего рода модель возможного дальнейшего развития музыкально-психологического и музыкотерапевтиче- ского знания, находящегося в тесной связи с запросами практики и требованиями времени, что представляет интерес и сегодня для развития данных сорер науки и образования.

\section{БИБЛИОГРАФИЯ}

1. Бехтерев В. М. Личность и условия её развития и здоровья // Проблемы развития и воспитания человека. Избранные психологические труды / под ред. А. В. Брушлинского и В. А. Кольцовой. М.: Изд-во МПСИ; Воронеж: МОДЭК, 2010. С. 98-138.

2. Владимир Михайлович Бехтерев как организатор // Вестник знания. Л., 1926. № 6. С. 419 420.

3. Бехтерев В. М. Пантеон мозга // Вестник знания. 1927. № 21. С. 1315-1318.

4. Бехтерев В. М. О сочетательно-рефлекторной терапии. Доклад, сделанный на съезде по охране здоровья детей и подростков, состоявшемся 16/XI 1925 года // Бехтерев В. М. Избранные произведения. М.: Медгиз, 1954. С. 436-441.

5. Бехтерев В. М. Значение музыки в эстетическом воспитании ребёнка с первых дней его детства. Доклад на совместном заседании педагогической сессии и Комиссии по изучению влияния музыки на организм в Психоневрологическом институте, май, 1914 // Проблемы развития и воспитания человека. Избранные психологические труды / под ред. А. В. Брушлинского и В. А. Кольцовой. М.: Изд-во МПСИ; Воронеж: МОДЭК, 2010. С. 157-166.

6. Бехтерев В. М. Вопросы, связанные с лечебным и гигиеническим значением музыки // Обозрение психиатрии, неврологии и экспериментальной психологии. СПб. 1916. № 1-3. С. 105-124.

7. ЦГИА СПб. Ф. 2265. Оп. 1. Д. 834. Л. 1-4.

8. ЦГИА СПб. Ф. 2265. Оп. 1. Д. 835. Л. 1-2.

9. ЦГИА СПб. Ф. 2265. Оп. 1. Д. 836. Л. 1-2.

10. Бехтерев В. М., Никитин С. Музыка как лечебное средство! // Петербургская газета. 1913, 16 апреля.

11. Саккетти Л. А. Новое применение музыки // Биржевые ведомости. 1913, 17 апреля.

12. ЦГИА СПб. Ф. 2265. Оп. 1. Д. 491. Л. 3-4.

13. Михайлов C. E. Применение музыки к лечению больных // Обозрение психиатрии, неврологии и экспериментальной психологии. 1914. № 2. С. 102-112.

14. Отчёт по Клиническому противоалкогольному институту // Вопросы алкоголизма: вестник Клинического противоалкогольного института. СПб., 1913. Вып. 1.

15. Щелованов Н. М. Институт по изучению мозга и психической деятельности (отчёт о деятельности по 15 июля 1919 г.) // Вопросы изучения и воспитания личности. Пг., 1920. № 1. C. $148-182$.

16. Щелованов Н. М. Отчёт о работах Института по изучению мозга и психической деятельности за вторую половину 1919 г. и за 1920 г. // Вопросы изучения и воспитания личности. Пг., 1921. № 3. С. 472-500.

17. Басов М. Я.Новые данные к обоснованию естественно-экспериментального метода исследования личности // Вопросы изучения и воспитания личности. Пг., 1922. № 4-5. С. 921-933. 
18. ЦГАЛИ СПб. Ф. 42. ОП. 1. Д. 15. Л. 30-30 об.

19. ЦГАЛИ СПб. Ф. 42. Оп. 1. Д. 24. Л. 88-89 об.

20. ЦГАЛИ СПб. Ф. 42. Оп. 1. Д. 24. Л. 44.

21. ЦГАЛИ СПб. Ф. 42. ОП. 1. Д. 15, Л. 21, 21 об.

22. ЦГАЛИ СПб. Ф. 42. Оп. 1. Д. 25. Л. 74, 75.

23. ЦГАЛИ СПб. Ф. 42. ОП. 1. Д. 25. Л. 18 об.

24. ЦГАЛИ СПб. Ф. 42. ОП. 1; Ф. 41. ОП. 1.

Поступила 10.03.2019; принята к публикации 15.03.2019.

\section{Об ав торе:}

Орлова Екатерина Марковна, преподаватель кафедры философии, истории, теории культуры и искусства Московского государственного института музыки имени А. Г. Шнитке (ул. Маршала Соколовского, 10, Москва, Российская Федерация, 123060), кандидат психологических наук, katsender@mail.ru

\section{Авторол прочитан и одобрен окончательный вариант рукописи.}

\section{REFERENCES}

1. Bekhterev V. M. Lichnost' i usloviya ee razvitiya i zdorov'ya [Personality and conditions of its development and health]. Problemy razvitiya i vospitaniya cheloveka. Izbrannye psikhologicheskie trudy [Problems of human development and education. Selected psychological works]. Under the editorship of A. V. Brushlinsky and V. A. Kol'tsova. Moscow: MPSI Publ.; Voronezh: MODEK Publ., 2010, pp. 98-138 (in Russian).

2. Vladimir Mikhajlovich Bekhterev kak organizator [Vladimir Mikhailovich Bekhterev as organizer]. Vestnik znaniya, 1926, no. 6, pp. 419-420 (in Russian).

3. Bekhterev V. M. Panteon mozga [Pantheon of the brain]. Vestnik znaniya, 1927, no. 21, pp. 13151318 (in Russian).

4. Bekhterev V. M. O sochetatel'no-reflektornoj terapii. Doklad, sdelannyj na s'ezde po okhrane zdorov'ya detej i podrostkov, sostoyavshemsya 16/XI 1925 goda [On combination-reflex therapy. Report made at the Congress on the health of children and adolescents, held 16/XI 1925]. Bekhterev V. M. Izbrannye proizvedeniya [Selected works]. Moscow: Medgiz Publ., 1954, pp. 436-441 (in Russian).

5. Bekhterev V. M. Znachenie muzyki v esteticheskom vospitanii rebenka s pervykh dnej ego detstva. Doklad na sovmestnom zasedanii pedagogicheskoj sessii i Komissii po izucheniyu vliyaniya muzyki na organizm v Psikhonevrologicheskom institute, maj, 1914 [The Importance of music in the aesthetic education of the child from the first days of his childhood. Report at a joint meeting of the pedagogical session and the Commission for the study of the influence of music on the body at the Psychoneurological Institute, May 1914]. Problemy razvitiya $i$ vospitaniya cheloveka. Izbrannye psikhologicheskie trudy [Problems of human development and education. Selected psychological works]. Under the editorship of A. V. Brushlinsky and V. A. Kol'tsova. Moscow: MPSI Publ.; Voronezh: MODEK Publ., 2010, pp. 157-166 (in Russian).

6. Bekhterev V. M. Voprosy, svyazannye s lechebnym i gigienicheskim znacheniem muzyki [Questions connected with medical and hygienic value of music]. Obozrenie psikhiatrii, nevrologii 
i eksperimental'noj psikhologii [Review of psychiatry, neurology and experimental psychology], 1916, no. 1-3, pp. 105-124 (in Russian).

7. Tsentral'nyj gosudarstvennyj istoricheskij arkhiv Sankt-Peterburga (TsGIA SPb), coll. 2265, aids 1, fol. 834, pp. 1-4 (in Russian).

8. Tsentral'nyj gosudarstvennyj istoricheskij arkhiv Sankt-Peterburga (TsGIA SPb), coll. 2265, aids 1, fol. 835, pp. 1-2 (in Russian).

9. Tsentral'nyj gosudarstvennyj istoricheskij arkhiv Sankt-Peterburga (TsGIA SPb), coll. 2265, aids 1, fol. 836, pp. 1-2 (in Russian).

10. Bekhterev V. M., Nikitin S. Muzyka kak lechebnoe sredstvo! [Music as a therapeutic tool!] Peterburgskaya gazeta, 1913, 16 April (in Russian).

11. Sakketti L. A. Novoe primenenie muzyki [New application of music]. Birzhevye vedomosti, 1913, 17 April (in Russian).

12. Tsentral'nyj gosudarstvennyj istoricheskij arkhiv Sankt-Peterburga (TsGIA SPb), coll. 2265, aids 1, fol. 491, pp. 3-4 (in Russian).

13. Mikhajlov S. E. Primenenie muzyki k lecheniyu bol'nykh [The Application of music to the treatment of patients]. Obozrenie psikhiatrii, nevrologii i eksperimental'noj psikhologii [Review of psychiatry, neurology and experimental psychology], 1914, no. 2, pp. 102-112 (in Russian).

14. Otchet po Klinicheskomu protivoalkogol'nomu institutu [Report on the Clinical anti-Alcohol Institute]. Voprosy alkogolizma: vestnik Klinicheskogo protivoalkogol'nogo institute [Questions of alcoholism: Bulletin of the Clinical anti-Alcohol Institute]. St. Petersburg, 1913. Issue 1 (in Russian).

15. Shchelovanov N. M. Institut po izucheniyu mozga i psikhicheskoj deyatel'nosti (otchet o deyatel'nosti po 15 iyulya 1919 g.) [Institute for the study of brain and mental activity (activity report for July 15, 1919)]. Voprosy izucheniya $i$ vospitaniya lichnosti [Questions of studying and education of the individual]. Petrograd, 1920, no. 1, pp. 148-182 (in Russian).

16. Shchelovanov N. M. Otchet o rabotakh Instituta po izucheniyu mozga i psikhicheskoj deyatel'nosti za vtoruyu polovinu 1919 g. i za 1920 g. [Report on the work of the Institute for the study of brain and mental activity during the second half of 1919 and 1920]. Voprosy izucheniya $i$ vospitaniya lichnosti [Questions of studying and education of the individual]. Petrograd, 1921, no. 3, pp. 472500 (in Russian).

17. Basov M. Ya. Novye dannye k obosnovaniyu estestvenno-eksperimental'nogo metoda issledovaniya lichnosti [New data to the substantiation of the natural-experimental method of personality research]. Voprosy izucheniya $i$ vospitaniya lichnosti [Questions of studying and education of the individual]. Petrograd, 1922, no. 4-5, pp. 921-933.

18. Tsentral'nyj gosudarstvennyj arkhiv literatury i iskusstva Sankt-Peterburga (TsGALI SPb), coll. 42, aids 1 , fol. 15 , pp. 30-30 back (in Russian).

19. Tsentral'nyj gosudarstvennyj arkhiv literatury i iskusstva Sankt-Peterburga (TsGALI SPb), coll. 42, aids 1, fol. 24, pp. 88-89 back (in Russian).

20. Tsentral'nyj gosudarstvennyj arkhiv literatury i iskusstva Sankt-Peterburga (TsGALI SPb), coll. 42, aids 1, fol. 24, p. 44 (in Russian).

21. Tsentral'nyj gosudarstvennyj arkhiv literatury i iskusstva Sankt-Peterburga (TsGALI SPb), coll. 42, aids 1, fol. 15, pp. 21, 21 back (in Russian).

22. Tsentral'nyj gosudarstvennyj arkhiv literatury i iskusstva Sankt-Peterburga (TsGALI SPb), coll. 42, aids 1, fol. 25, pp. 74, 75 (in Russian).

23. Tsentral'nyj gosudarstvennyj arkhiv literatury i iskusstva Sankt-Peterburga (TsGALI SPb), coll. 42, aids 1, fol. 25, p. 18 back (in Russian). 
Музыкальная психология, психология музыкального образования

24. Tsentral'nyj gosudarstvennyj arkhiv literatury i iskusstva Sankt-Peterburga (TsGALI SPb), coll. 42, aids 1; coll. 41, aids 1 (in Russian).

Submitted 10.03.2019; revised 15.03.2019.

About the author:

Ekaterina M. Orlova, Teacher at the Department of Philosophy, History, Theory of Culture and Art, Moscow State Institute of Music named after A. G. Schnittke (Marshala Sokolovskogo Street, 10, Moscow, Russian Federation, 123060), PhD of Psychology, katsender@mail.ru

The author has read and approved the final manuscript. 


\section{ИСТОРИЯ И ТЕОРИЯ МУЗЫКАЛЬНОЙ ПИСЬМЕННОСТИ КАК УЧЕБНАЯ ДИСЦИПЛИНА}

\section{С. Е. Энглин,}

Федеральное государственное бюджетное научно-исследовательское учреждение «Российский институт истории искусств», Санкт-Петербург, Российская Федерация, 190000

Аннотация. В статье расслатриваются причины, согласно которыли современный музыковед долюен быть колпетентен в вопросах истории и теории нотаиии. Результаты исследований систел граббческой записи лузыки предлагается приленять в образовательньх иелях. Это обусловлено тел, что в нотации отражаются некоторье важнейшие черты музыкального мышления эпохи её становления. Следовательно, познание конкретных видов музыкальной селейограббии является средствол получения объективных данных о глубинных началах музыки конкретного исторического периода (врелени создания и по крайней мере первоначального бытования данной нотации). Анализируются взаилосвязанные вопросы изучения нотации и основных задач музыкознания. Введение учебного курса музыкальной селейографии видится в свете многоаспектной проблемь музыкального образования и науки. Делается вывод о тол, что внедрение образовательного предлета "История и теория музыкальной письленности» при условии координации усилий учёньх, направленньх на создание совреленной концепиии селейологии, будет способствовать постижению сущности музыкальной письленности на основе обобщения результатов селейологических изысканий. В свою очередь, это станет существенньлм шагол на пути познания общелузыкальных законолерностей, отразившихся в различных нотографбиях.

Ключевые слова: музыкальное образование, теория и история музькальной письленности, музыкальная селейология, музыкальная логика нотации, музыкальное мышление, античная нотация, музыкальное антиковедение.

Благодарности: Сердечно благодарю моего Учителя Евгения Владимировича Герилана, уникального специалиста в области музыкального антиковедения.

Для цитирования: Энглин C. E. История и теория музыкальной письменности как учебная дисциплина // Музыкальное искусство и образование. 2019. Т. 7. № 1. С. 95-106. 


\title{
HISTORY AND THEORY OF MUSICAL WRITING AS AN ACADEMIC DISCIPLINE
}

\section{Stanislav E. Englin,}

Federal State Budgetary Research Institution Russian Institute of Art History, St. Petersburg, Russian Federation, 190000

\begin{abstract}
The article outlines the reasons why the modern musicologist must be competent in matters of history and theory of a notation. Results of research of the systems of graphical writing of music are proposed to be used in educational purposes. This is due to the fact that the notation is reflected some of the most important features of the musical thinking of the era of its formation. Therefore, knowledge of specific types of music semiography is a tool of obtaining objective data on the deep principles of music of the specific historical period (time of creation and at least, the initial existence of this notation). The interconnected subjects analyze the study of the notation and the basic tasks of musicology. Introduction of training course of music semiography be seen in the light of the multidimensional problem of music education and science. It is concluded that the implementation of educational subject "History and theory of musical writing" provided the coordination of efforts of scientists aimed at creating a modern concept of semiography, contributes to the attainment the essence of musical writing on the basis of generalization of the results of semiography studies. In turn, this will be a significant step on the path of knowledge absolutely patterns, reflected in the variety notations.
\end{abstract}

Keywords: Musical Education, History and Theory of Musical Writing, Musical Semiography, Musical Logic of Musical Notation, Musical Thinking, Ancient Greek Musical Notation, Studies in Ancient Greek and Roman Music.

Acknowledgements: I am sincerely grateful to my Teacher E. V. Gertsman, the brilliant specialist in the studies in Ancient Greek and Roman Music.

For citation: Englin S. E. History and theory of musical writing as an academic discipline. Muzykal'noe iskusstvo $i$ obrazovanie = Musical Art and Education, 2019, vol. 7, no. 1, pp. 95-106. 


\section{Введение}

Постижение музыкальной логики систем нотации - задача, уже достаточно давно осознанная исследователями. Прекрасно её сформулировал В. Г. Карцовник в статье «Палеография и семиология (к изучению ранних систем музыкальной письменности)». Он подчёркивает, что нотное письмо «предстаёт языком самоописания породившей его музыкальной традиции» [1, с. 261]. Дело в том, что любая музыкальная письменность отражает некоторые базовые музыкально-смысловые закономерности. Их исследование открывает дорогу к основополагающим свойствам, присущим музыкальному мышлению той цивилизации, что формировала конкретную графическую запись музыки. В музыкознании уже не впервые ставится вопрос о необходимости исследования нотаций как систем, несущих на себе отпечаток музыкального мышления эпох, их породивших. Тем не менее в науке о музыке и музыкальном образовании (а эти институции должны былть непосредственно взаилосвязаны и взаилозависильь!) до сих пор не предприняты усилия, чтобы предмет «История и теория музыкальной письменности» был повсеместно введён в учебные курсы.

Это представляется чрезвычайно странным. Ведь внедрение предмета и создание современного учебного пособия, в котором излагаются и обобщаются результаты исследования нотаций, вызвано насущной научной и учебной потребностями. Ибо главный вопрос изучения музыкальной семейографии звучит так: как нотации отразили закономерно- сти музыкального мышления эпох, в ралках которьх они возникали?

Решение такой основополагающей, глобальной проблемы не может быть уделом узких кругов специалистов. Необходимо объединить исследователей нотаций, достичь общего понимания целей и задач. Не менее важна и целенаправленная подготовка будущих учёных, занимающихся вопросами музыкальной письменности. Более того, любому музыковеду надлежит быть осведомлённым о семейологической проблематике изучаемой им эпохи, что невозможно без введения соответствующего предмета в учебные курсы. В настоящей статье рассматриваются причины, согласно которым в круг компетенций современного музыковеда обязательно должно входить по меньшей мере общее представление о проблематике музыкальной письменности.

\section{Нотация \\ и музыкальное мышление}

На современном этапе развития науки нотационные исследования более не могут рассматриваться в качестве специфической отрасли музыкознания, некой «экзотики», которой занимаются лишь немногие. Ибо понимание основ музыки различных времён и народов непосредственно связано иленно с нотацией. В нотации запечатлены те свойства записываемой с её помощью музыки, которые были актуальны в период зарождения конкретной музыкальной письменности.

Познание же специфики музыки в исторической перспективе, изучение основ музыкального мышления - главная цель музыкальной науки. Не думаю, что кто-либо всерьёз 
будет оспаривать это утверждение. Во всяком случае, М. Г. Арановский - учёный, глубоко понимавший, какие актуальные задачи стоят перед наукой о музыке, считал, что миссией музыковедения является «изучение музыкального мышления как главной духовной силы музыки...» [2, с. 405]. Эти слова, опубликованные в посмертном сборнике его трудов, можно считать своеобразным завещанием, мудрым наставлением будущим исследователям.

Конечно, говоря о специфике музыкального мышления в зеркале нотации, мы не можем подразумевать музыкальное сознание конкретного индивидуума. Применительно к той или иной системе нотации категорию музыкального мышления следует рассматривать с глобальной точки зрения - как совокупность важнейших черт, присущих музыке той или иной эпохи, и таким образом определяющих склад музыкального мышления. Такое ограничение области применения обсуждаемого термина в контексте нотографической сферы науки обусловлено определённой универсальностью (можно сказать, «всеядностью»), которая свойственна нотациям.

Совершенно очевидно, что музыкальная письменность отвечает критериям употребительности в контексте конкретной музыкальной среды. Следовательно, по мере формирования нотации происходит её оптимизащия, обеспечивающая удобство использования. В этом смысле семейография приобретает некоторую универсальность. Безусловно, в данном случае «универсальность» нотации качество, ограниченное во времени и пространстве. Отдельной проблемой является определение границ адаптащионных возможностей графической записи музыки. Действительно, очень трудно понять, когда эпохальные изменения музыкального сознания требуют создания новой нотации, каков потенциал конкретных семейографиий к приспособлению и изменению согласно требованиям новой музыки. Адаптивные возможности нотации - вообще та тема, которая заслуживает отдельного исследования. Более того, дискуссионным может быть и вопрос определения разновидностей нотации. Нужно вырабатывать чёткие (насколько возможно) критерии дифрференциации форм музыкальной письменности, различать самостоятельные семейографии и типы одной и той же нотации.

В любом случае ясно одно: нотации в тех или иных рамках как бы «всеохватны», а способ записи, созданный специально ради фиксации одного-единственного произведения и тем самым отражающий закономерности мышления одного-единственного музыканта, вряд ли может считаться полноценной нотацией. Конечно, коллеги могут на этот счёт придерживаться иного мнения, но в настоящей статье я не вижу необходимости вступать в дискуссию по этому поводу.

Таким образом, если наука о музыке стремится приблизиться к указанной сверхзадаче и пытается познавать некие глубинные основы искусства, то музыкальная запись один из важнейших инструментов доказательного, подлинно научного исследования музыки. В самом деле, много ли вообще в музыкознании подобных научных инструментов, анализ которых открывает перспективы 
достаточно объективного сбора данных об основах музыкального мышления?! Безусловно, нужно отдавать себе отчёт в том, что интерпретация данных, полученных таким способом, не может избежать субъективности. И это следует обсудить более подробно.

Если интерпретация объективных данных нотации связана с деятельностью небольшого числа специалистов, то возрастает степень субъективности выводов, риск заблуждений и даже фрактических ошибок становится слишком велик! Выходом из такой ситуации является лишь фрормирование научного сообщества, в рамках которого нотационные исследования подвергались бы тщательному и высокопрофессиональному обсуждению. Тем самым становится очевидной необходимость расширения круга исследователей, изучающих её. Такому расширению научного потенциала способствовало бы музыкальное образование, в рамки которого входил бы предмет «История и теория музыкальной письменности».

Очевидно, что выводы, основополагающие для науки о музыке, можно делать при условии чёткой направленности семейологических исследований на выявление данных, упомянутых выше, и должной оценке их значения. Важнейшим результатом исследований конкретных нотаций являются, прежде всего, раскрытие их базовых характеристик, которые, в свою очередь, возникли на основе глубинных закономерностей музыки конкретных эпох и цивилизаций. В связи с этим не следует ли музыковедческому сообществу инициировать процесс переоценки роли нотационных исследований в науке?
Итак, всё говорит о том, что главный вопрос изучения нотации непосредственно связан с основной задачей музыкознания. Теперь важно подчеркнуть следующее: музыкальное образование должно наконеи отреагировать на запросы музыкальной науки.

\section{Нотация \\ и музыкальное образование}

Как уже было сказано, нотация требует гораздо более интенсивного изучения, что вызывает необходимость расширять кадровый потенциал - активно рекрутировать молодых музыковедов в сферу исследования нотации. Изучая семейологию как образовательный предмет, студенты познакомятся с актуальными аспектами исследования музыкальной письменности, и в результате у них возникнет понимание того, что нотация - один из «ключей» к постижению музыкального мышления. Ведь система графической записи никогда не тождественна отвлечённой «объективной регистрации» звучащего материала, ибо нотация формируется в рамках конкретной музыкальной цивилизации с присущими ей особенностями. Введение нотографии в курсы музыкальных вузов включит механизмы плодотворного двустороннего процесса. С одной стороны, общая семейология музыки позволит студентами историко-теоретических фракультетов приобщаться к знаниям, способствующим пониманию базисных основ музыкального искусства. Речь идёт о некоторых важных чертах музыкального мышления конкретной эпохи, которые нашли отражение в нотации. С другой стороны, сама семейология полу- 
чит необходимую «среду обитания» ту критическую массу новых научных сил, которая способна создать условия для будущего интенсивного развития обсуждаемой отрасли музыкознания. Ибо профессиональные контакты квалифицированных исследователей - катализатор эволюции нотационных исследований.

Решение указанной проблемы музыкального образования и науки требует весьма значительных организационных и исследовательских усилий. Автор этих строк, занимаясь античной нотацией, сталкивается с объективными трудностями апробации и внедрения результатов своего исследования в музыковедческий обиход. Как известно, в настоящее время не только не сфрормировалось профрессиональное сообщество музыкальных антиковедов, специализирующихся в области нотации, но и не институционализирована целая отрасль музыкознания музыкальное антиковедение (подлинным основоположником этой сферы науки о музыке является мой Учитель Евгений Владимирович Герцман - автор множества монографий о музыке древних эллинов и византийцев (см., например: [3-6]).

Для данной специализации необходимо сочетание музыковедческих и фрилологических компетенций. За всю историю изучения древней музыки таких учёных были единицы. Тех, кто глубоко разбирался в греческой музыкальной семейографии, ещё меньше. Специалистам в этой научной области неоткуда появиться ещё и потому, что в образовательных программах, как уже неоднократно было отмечено, отсутствует полноценный курс истории и теории музыкальной письменности.
Проблематика, обсуждаемая в настоящей статье, тесно связана с крепко укоренившейся порочной практикой преподавания истории музыки. За редким исключением, полноценное изучение музыкального прошлого в вузе начинается с эпохи Баха и Генделя. Искусству более отдалённых времён уделяется лишь небольшое количество часов, а такую «экзотику», как Античность или Древний Восток, нередко вообще оставляют студентам на самостоятельную работу. Формируется ли у молодого музыканта сколько-нибудь полное представление об историческом процессе, если обучение истории музыки сопряжено с вопиюще неравноценным изучением музыкально-исторических эпох? Сказанное в полной мере относится и к нотационным системам.

\section{Нотные транскрипции и память нотации}

Не вызывает сомнения, что для полноценного понимания общих вопросов нотации требуется изучение всего спектра известных музыкальных семейографий, включая, безусловно, первую европейскую систему записи музыки - античную нотацию. И здесь мы столкнёмся с другой проблемой, о которой также необходимо упомянуть. Как известно, до сих пор не только традиции обучения, но и научная деятельность абсолютного большинства музыковедов были связаны с изучением последних трёхчетырёх столетий. Исследование же более древних эпох остаётся уделом незначительного числа учёных. В результате наука оперирует только теми данными, которые выявлены ею на довольно ограниченном историческом отрезке музыкального 
развития человечества. Как следствие, она не имеет возможности разделить выявленные закономерности на те, которые свойственны отдельным историческим эпохам, и те, которые являются всеобщими законами музыки. Только активизируя изучение древних музыкальных культур, мы сможем рассчитывать, что рано или поздно будут выявлены объективные фракторы, оказывающие влияние на процесс развития музыкального искусства.

Одновременно с этим следует отдавать себе отчёт, что изучение музыки, отдалённой от нас во времени и/или пространстве сопряжено с проблемой, решение которой опять-таки связано с семейологией. Строго говоря, нотографическое наследие музыкальной практики определённой цивилизации нельзя даже называть адекватным отражением музыкальных произведений, так как система нотации не способна отобразить во всех тонкостях сочинение, запечатлённое с её помощью. Она условно переводит музыкальную информацию в графический вид. Транскрипции же в пятилинейную нотацию являются ничем иным, как своего рода двойным переводом, поскольку всякое подобное транскрибирование представляет собой передачу, в основе которой лежит не первоисточник (звучащий музыкальныцй материал), а его письленное воплощение.

При всей условности сравнения такие «версии» музыкальных документов, изначально зафиксированных при помощи нотации, отличной от пятилинейной, подобны транслитерации. Такова, например, общеизвестная практика записи русских слов с помощью латинских букв, ко- торая служит подспорьем для тех, кто не ориентируется ни в фонетических, ни, что более важно, в смысловых параметрах русской речи. Нечто подобное происходит в тех случаях, когда иностранец, не знающий русского языка, должен произнести несколько слов «по-русски». Чтобы облегчить свою участь и как-то усвоить набор бессмысленных звуковых сочетаний, он прибегает к транслитерации, то есть записывает понятными ему буквами незнакомый по смыслу текст. Когда же в процессе изучения языка начинает осознаваться смысл такого текста, то становится понятно, что «помогавшая» на ранних этапах транслитерация неудобна, неестественна и на новом, более высоком этапе изучения не нужна. То же самое имеет место при переносе музыкального материала на ныне общепринятую систему нотации, так как с одного музыкального «алфавита», созданного для адекватного ему искусства, текст механически переносится на другой, отвечающий особенностям иной музыкальной речи, иного музыкального языка.

Дело в том, что в любой графической записи звука непременно фриксируется нечто большее, чем просто звучащий френомен (с его высотой, ритмом, а в высокоразвитых нотных системах - динамикой, звукоизвлечением и т. д.). Как известно, ныне распространённая система основана на октавной тождественности звуков в рамках семиступенной диатоники. Таким образом, линейная нотация невольно несёт на себе отпечаток музыкального мышления времени её формирования. Подобная информация заложена и в других нотных системах. 
Речь идёт о паля $m u$ но $m a u, u$, то есть об основополагающих свидетельствах об особенностях музыкального сознания, отражённых в нотной письменности. Их необходимо познавать, ибо в противном случае понимание нотации остаётся на уровне транслитерации. Только при верном познании памяти нотации она поможет разгадать особенности музыкального сознания своей эпохи.

Что же касается возможности приложения информации, выявленной в результате изучения нотации, к конкретным явлениям музыкального искусства, то в данном случае возникает необходимость учитывать исторические параметры анализируемого материала. Так, совершенно очевидно, что сочинения, записанные при помощи нотолинейной системы, зачастую демонстрируют «не предусмотренные» ею виды диатоники (например, двенадцатиступенные). Тем не менее эти френомены звуковысотная письменность как бы «не замечает», представляя каждый «нотный фракт» в единственно возможной для себя форме. Однако следует подчеркнуть, что при всей «компромиссности» такой музыкальной семейографии, она до сих пор ещё не утратила наглядности и удобства в употреблении, так как для современного музыкального мышления принципиальна демонстрация идентичности звуков октавы, а все остальные детали априори достраиваются в сознании тех, кто причастен к современной музыкальной традиции.

Таким образом, в музыке, зафиксированной при помощи нотации, отражаются основополагающие особенности музыкального мышления, в условиях которого формировалась данная графическая система. Несомненно, чем больший отрезок времени отделяет нотографический образец от эпохи становления данной музыкальной письменности, тем значительнее погрешности семейографической информации. Однако сам фракт применения того или иного вида музыкальной письменности свидетельствует о том, что по крайней мере её базовые характеристики ещё не вошли в противоречие с музыкальной практикой. В противном случае нотация становится столь неудобной, что возникает необходимость создавать новую систему.

Исследуя механизмы функционирования античной музыкальной записи, я пришёл к заключению о том, что в ней зафиксированы ладофрункциональные параметры эпохи её становления - один из важнейших фракторов музыкального мышления. Точнее говоря, скрупулёзное изучение строения музыкальной семейографии и деталей её применения подтверждает догадку Е. В. Герцмана, высказанную ещё в одном из его ранних исследований [4, с. 115, 201]. По мнению учёного, ладовая идентичность ступеней, отстоящих друг от друга на кварту, нашла подтверждение в нотации. Необходимо только отметить, что вне зависимости от того, отразилась ли в нотаџии именно тетрахордная идентичность, типологическое подобие звуков на расстояниях, кратных кварте, очевидно, наблюдается в античной звуковысотной нотации [7; 8]. Во всяком случае нотация тем или иным способом маркирует сопряжённость пар звуков, находящихся в основании тетрахорда (как известно, в античности различались три те- 
трахордных лада: диатонический, $1 / 2$ т. - 1 т. - 1 т.; хроматический, $1 / 2$ т. $1 / 2$ т. - 1,5 т.; энгармонический, $1 / 4$ т. $1 / 4$ т. - 2 т.). Музыкальная письменность реагирует на соотношения двух первых звуков диатонического тетрахорда (если представлять себе звукоряд снизу вверх) и даже трёх звуков в хроматике и энгармонии. Такой френомен структуры нотографии свидетельствует об адекватности античных музыкально-теоретических представлений о ладе.

Кроме того, и звуковысотные, и незвуковысотные (ритмические и артикуляционные) знаки обладают ещё одним свойством, свидетельствующим об особенностях музыкального мышления. Ноты античной эпохи суть элементы - звуковые и ритмические «точки». На высотном уровне это проявляется в том, что каждая нота обозначает отдельный звук (хотя логика применения знаков основывается, конечно, на соотношениях звуков-элементов), а на ритмическом - в принципе суммирования длительностей. В нотных текстах помечались звуки и паузы, длящиеся два «хроноса протоса» (в античности так обозначалась мельчайшая ритмическая единица), три, четыре и, по крайней мере в теории, пять; собственно «хронос протос» отдельного обозначения не имел. Особый символ был также предусмотрен для слабого, безударного времени («арсиса»). Вместе с тем артикуляционные символы (гифен, комписм, мелисм и, возможно, так называемый двойной колон) объединяли несколько звукоэлементов (подробнее о незвуковысотной нотации античности см. [9; 10]). Следовательно, не только наука древних эллинов, но и музыкальная практика (нотация - порождение художественной практики, а не теории) воспринимала музыкальные явления, диффреренцируя их по элементам - отдельным звукам, письменный вид которых указывали отдельные ноты. Здесь необходимо провести аналогию со словесной письменностью, в которой отдельный звук воплощался через отдельную букву, да и сами ноты, как свидетельствуют их графический облик и древние источники, воспринимались в качестве букв и произошли от литер (не случайно мы называем античную нотацию буквенной).

Высказанные соображения об античной нотации могут пройти истинную апробацию только при условии активизации комплексного изучения систем музыкальной письменности (и античной, и прочих). Нотация, понимаемая как «язык самоописания» музыкальной цивилизации, ценнейший и объективный источник, который даёт возможность увидеть специфическую логику, характерную для эпохи создания графической записи музыки.

\section{Заключение}

Таким образом, изучение нотации является путём познания объективных закономерностей музыки, которые лежат в основе различных систем музыкальной письменности.

На сегодняшний же день приходится констатировать, что музыковедение находится всё ещё в начале этого пути. Слабая координация науки и образования в семейологической области приводит к целому ряду последствий. Среди них необходимо упомянуть недостаточную распространённость знания о нотных 
системах, отсутствие полноценных научных трудов, на современном уровне обобщающих достижения исследователей отдельных нотаций, а также небольшое количество специалистов, изучающих нотную письменность. В результате получается, что наука о музыке не реализует всех своих возможностей.

Остаётся лишь надеяться на то, что в обозримом будущем появится музыкально-историческая и теоретическая учебная дисциплина, обобщающая результаты семейологических исследований. Очевидно, можно ожидать интенсификацию процесса исследования только тогда, когда будут созданы условия для подготовки соответствующих специалистов. Ведь проверка, применение и развитие тезисов, высказываемых в работах, посвящённых различным нотациям, возможны лишь при адекватной подготовке научных кадров. То же самое относится и к обобщениям результатов семейологических изысканий. Более глобальные исследования сущности музыкальной письменности в целом и - шире - общемузыкальных закономерностей, отразившихся в различных нотографиях, станут осуществимы после возникновения соответствующей учебной дисциплины и при условии координации усилий учёных, направ- ленных на создание современной концепции семейологии.

Несомненно, введение курса истории и теории нотаций предполагает наличие учебника, который будет включать в себя:

- историческую информацию;

- характеристику параметров фоксации музыки, которые присущи конкретной нотации;

- обзор теоретических источников и данных, почерпнутых из музыкальной практики;

- краткие экскурсы в историю изучения нотаций;

- выводы о том, каким образом каждая нотация отразила особенности музыкального мышления своей эпохи и фрормы его проявления в элементах нотной записи.

Конечно, осуществление такого проекта потребует большого авторского коллектива, поскольку современные знания даже об одной нотации, как правило, столь обширны, что редкий специалист способен охватить несколько систем музыкальной письменности.

Изучение нотации уже слишком долго пребывает в герметизированном состоянии, и потенциал семейологической отрасли науки о музыке в целом остаётся недостаточно раскрытым и недооценённым. Надеюсь, что материал этой статьи активизирует обсуждение затронутой проблемы.

\section{БИБЛИОГРАФИЯ}

1. Карцовник В. Г. Палеография и семиология (к изучению ранних систем музыкальной письменности) // Музыкальная коммуникация: сб. науч. трудов / РИИИ; ред.-сост. Л. Н. Березовчук. Вып. 8. СПб.: Изд-во Российского института истории искусств, 1996. С. 260-275. [Серия «Проблемы музыкознания»].

2. Арановский М. Г. Музыка. Мышление. Жизнь: Статьи, интервью, воспоминания / ред.-сост. Н. А. Рыжкова. М.: Изд-во Государственного института искусствознания, 2012. 440 с.

3. Гериман E. В. Античное музыкальное мышление. Л.: Музыка, 1986. 224 с. 
4. Гериман Е. В. Византийское музыкознание. Л.: Музыка, 1988. 256 с.

5. Гериман E. B. Пифагорейское музыкознание. Начала древнегреческой науки о музыке. СПб.: Гуманитарная Академия, 2003. 384 с.

6. Гериман E. B. Энциклопедия древнеэллинской и византийской музыки: в 3 т. СПб.: Издательский проект «Квадривиум»; Проект Вячеслава Заренкова «Созидающий мир», 2019. 1072 c., 1136 c., 816 c.

7. Энглин C. Е. Музыкальная логика античной нотации // Hyperboreus. Studia classica. Petropoli: Verlag C. H. Beck (München), 2002. Vol. 8. Fasc. 1. S. 122-144 (Bibliotheca Classica Petropolitana).

8. Энглин C. E. Нотация буквенная // Герцман Е. В. Энциклопедия древнеэллинской и византийской музыки: в 3 т. Т. 2: К-П. СПб.: Издательский проект «Квадривиум»; Проект Вячеслава Заренкова «Созидающий мир», 2019. С. 584-621.

9. Энглин С. Свидетельства античной исполнительской артикуляции в «названиях, нотах и формах мелоса» // Theorie und Geschichte der Monodie: Festschrift für Bozhidar Karastoyanov anlässlich seines 70. Geburtstags / M. Czernin, M. Pischlöger (Hrsg.). Bd. 3. Brno, 2011. S. 55-82.

10. Энглин C. Метроритмические обозначения античной нотации // Музыка в культурном пространстве Европы - России. События. Личность. История / отв. ред. и сост. Н. А. Огаркова. СПб.: Изд-во Российского института истории искусств, 2014. С. 26-40.

Поступила 15.02.2019; принята к публикации 15.03.2019.

\section{Об авторе:}

Энглин Станислав Евгеньевич, научный сотрудник Федерального государственного бюджетного научно-исследовательского учреждения «Российский институт истории искусств» (РИИИ) (Исаакиевская пл., д. 5, СанктПетербург, Российская Федерация, 190000), кандидат искусствоведения, sten1900@mail.ru

\section{REFERENCES}

1. Kartsovnik V. G. Paleografiya i semiologiya (k izucheniyu rannikh sistem muzykal'noj pis'mennosti) [Paleography and Semiology (to the research of early systems of musical writing)]. Muzykal'naya kommunikatsiya: sb. nauch. trudov [Musical Communication: collection of scientific works]. Compiler and editor L. N. Berezovchuk. Issue 8. St. Petersburg: Rossijskij institut istorii iskusstv Publ., 1996, pp. 260-275 (in Russian).

2. Aranovsky M. G. Muzyka. Myshlenie. Zhizn': Stat'i, interv'yu, vospominaniya [Music. Thinking. Life. Articles, interviews, memoires]. Compiler and editor N. A. Ryzhkova. Moscow: Gosudarstvennyj institut iskusstvoznaniya Publ., 2012. 440 p. (in Russian).

3. Gertsman E. V. Antichnoe muzykal'noe myshlenie [Ancient Musical Thinking]. Leningrad: Muzyka Publ., 1986. 224 p. (in Russian).

4. Gertsman E. V. Vizantijskoe muzykoznanie [Byzantine Musicology]. Leningrad: Muzyka Publ., 1988. 256 p. (in Russian).

5. Gertsman E. V. Pifagorejskoe muzykoznanie. Nachala drevnegrecheskoj nauki o muzyke [Pythagorean Musicology. Foundations of the Ancient Greek Musical Science]. St. Petersburg: Gumanitarnaya Akademiya Publ., 2003. 384 p. (in Russian). 
6. Gertsman E. V. Entsiklopediya drevneellinskoj i vizantijskoj muzyki [Encyclopedia of the Ancient Greek and Byzantine Music]. In 3 volumes. St. Petersburg: Izdatel'skij proekt "Kvadrivium"; Proekt Vyacheslava Zarenkova "Sozidayushchij mir", 2019. 1072 p., 1136 p., 816 p. (in Russian).

7. Englin S. E. Muzykal'naya logika antichnoj notatsii [Musical Logic of the Ancient Greek Musical Notation]. Hyperboreus. Studia classica. Petropoli: Verlag C. H. Beck (München), 2002. Vol. 8. Fasc. 1, pp. 122-144 (Bibliotheca Classica Petropolitana). (in Russian).

8. Englin S. E. Notatsiya bukvennaya [Letter Notation]. In: Gertsman E. V. Entsiklopediya drevneellinskoj $i$ vizantijskoj muzyki [Encyclopedia of the Ancient Greek and Byzantine Music]. In 3 volumes. Vol. 2. St. Petersburg: Izdatel'skij proekt "Kvadrivium"; Proekt Vyacheslava Zarenkova "Sozidayushchij mir" Publ., 2019, pp. 584-621 (in Russian).

9. Englin S. Svidetel'stva antichnoj ispolnitel'skoj artikulyatsii v "nazvaniyakh, notakh i formakh melosa" [The Evidences of the Ancient Greek performance technique in "Names, Notes and Forms of the Melos"]. Theorie und Geschichte der Monodie: Festschrift für Bozhidar Karastoyanov anlässlich seines 70. Geburtstags. M. Czernin, M. Pischlöger (Hrsg.). Bd. 3. Brno, 2011, pp. 55-82 (in Russian).

10. Englin S. Metroritmicheskie oboznacheniya antichnoj notatsii [Rhythmic Signs in the Ancient Greek Musical Notation]. Muzyka v kul 'turnom prostranstve Evropy - Rossii. Sobytiya. Lichnost'. Istoriya [Music in the Framework of European and Russian Cultures. Events. Personality. History]. Executive editor and compiler N. A. Ogarkova. St. Petersburg: Rossijskyj institut istorii iskusstv, 2014, pp. 26-40 (in Russian).

Submitted 15.02.2019; revised 15.03.2019.

About the author:

Stanislav E. Englin, scientific researcher, Federal State Budgetary Research Institution Russian Institute of Art History (RIAH) (St. Isaac's Square, 5, Saint Petersburg, Russian Federation, 190000), PhD in Arts, sten1900@mail.ru

The author has read and approved the final manuscript. 


\section{ФЕНОМЕН И СЕМАНТИКА ЗВУКА В СОВРЕМЕННОЙ МУЗЫКЕ КАК ПРЕДМЕТ ОСВОЕНИЯ В МУЗЫКАЛЬНОМ ОБРАЗОВАНИИ (НА МАТЕРИАЛЕ ТВОРЧЕСТВА АЛЕКСАНДРА БАКШИ)}

\section{О. А. Путечева',}

Некоммерческое образовательное частное учреждение высшего образования «Кубанский медицинский институт», Краснодар, Российская Федерация, 350015

Аннотация. Характер звука, уникальный и неповторилый в творчестве совреленных колпозиторов, кристаллизуется в сложных поисках музыкальной выразительности. В статье предпринята попытка проследить становление нового явления в отечественной лузыке - Театра звука, которое возложно осльслить с точки зрения значения отдельного звука в организации сочинений отечественного колпозитора Александра Бакши, где колористически рассчитан каждый из них, осознаваемьий исходныли элелентол создания произведения. Весолость акустической точки на пересечении сльслообразующих фбакторов различного плана позволяет считать каждый звук в музыкальном произведении селантически значилой единицей, поскольку он мгновенно отражает изленение содержания, чувствителен к ситуаиии, наделяется огролной энергией воздействия. В статье получают раскрытие некоторые особенности звуковой организации и её бундалентальная роль в авангардных сочинениях, что создаёт условия для поиска и выработки новых сльслов. Методика анализа инструлентальньх сочинений основана на движении от частных проявлений к обобщениял, касающился всего произведения и его сценической жизни. Творческий процесс сочинения данного автора уникален тел, что начинается с поиска и фборлирования единичного звука, дающего особое энергетическое напряжение с его телброл, характерол. Колпозитор извлекает из него максилул возложностей, используя ритлическую изменчивость, телбр, тесситуру, различные приёль звукоизвлечения. Индивидуализация способствует не только усилению выразительньх свойств, но и увеличению сльсловой и фбункииональной нагрузки более значительных построений. В результате возникают новые способы организации музыкальной ткани, основанные на ассоииациях, игре сльсла-

\footnotetext{
1 Научный консультант - доктор искусствоведения, профессор П. С. Волкова.
} 
ми, албивалентности. Колористическая работа, звуковые трансборлаиии усложняют код сльслопорождения, что характеризует изленение типа колмуникации. В связи с "визуальныли поворотол" вырабатываются новые типь кодов, способствуюшие объёлности восприятия произведения в полиселантическол иелол. Понилание сущности расслатриваелых процессов в музыкально-теоретическол аспекте - необходилое условие для включения творчества совреленньх колпозиторов в содержание лузыкального образования.

Ключевые слова: музыкальное образование, звук, селантика, "Театр звука", сонорно-акустические эбббекты, индивидуализаиия звука, звукоорганизация.

Благодарности: Статья выполнена в контексте направления научных исследований, посвящённых фбенолену и селантике звука. Автор выражает благодарность научнолу консультанту, доктору искусствоведения, профбессору П. С. Волковой.

Для цитирования: Путечева О. А. Феномен и семантика звука в современной музыке как предмет освоения в музыкальном образовании (на материале творчества Александра Бакши) // Музыкальное искусство и образование. 2019. Т. 7. № 1. С. 107-119.

\title{
THE PHENOMENON AND THE SEMANTICS OF SOUND IN MODERN MUSIC AS THE SUBJECT OF DEVELOPMENT IN MUSIC EDUCATION (BASED ON WORKS BY ALEXANDER BAKSHI)
}

\section{Olga A. Putecheva',}

Non-profit Private Educational Institution of Higher Education

"Kuban Medical Institute",

Krasnodar, Russian Federation, 350015

\begin{abstract}
The nature of the sound is unique and inimitable in the works of modern composers, crystallizing in the complex search for musical expression. The article attempts to trace the formation of a new phenomenon in Russian music - "Theater of sound", which is possible for comprehending in terms of value of a separate sound in the organization of compositions by the Moscow composer A. Bakshi where each of them realized by an initial element of creation of the work coloristic is calculated. The weight of the acoustic point at the intersection of sense-forming factors of different plan, allows us to consider each sound in
\end{abstract}

\footnotetext{
1 Scientific consultant - Doctor of Art History, Professor P. S. Volkova.
} 
a musical work semantically significant unit, because it instantly reflects the change in content, sensitive to the situation, is endowed with great energy impact. The article reveals some features of the sound organization and its fundamental role in vanguard compositions, which creates conditions for the search and development of new meanings. The method of analysis of instrumental works is based on the movement from particular manifestations to generalizations concerning the whole work and its stage life. The creative process of writing this author is unique in that it begins with the search and formation of a single sound, giving a special energy stress with its timbre, character. The composer extracts the maximum of possibilities from it, using rhythmic variability, timbre, tessitura, various methods of sound production. Individualization not only enhances the expressive properties, but also increases the semantic and functional load of more significant constructions. As a result, there are new ways of organizing the musical fabric, based on associations, the game of meanings, ambivalence. Coloristic work, sound transformations complicate the code of meaning generation, which characterizes the change in the type of communication. In connection with the "visual turn", new types of codes are developed that contribute to the volumetric perception of the work in the polysemantic whole. The understanding of the essence of the considered processes in the musical-theoretical aspect is a necessary condition for the inclusion of creativity of modern composers in the content of musical education.

Keywords: musical education, sound, semantics, "Theatre sound" soundacoustic effects, individualization of sound, two coordinates.

Acknowledgements: The article is completed in the context of the direction of scientific research devoted to the phenomenon and semantics of sound. The author is grateful for the help in the work on the article to the scientific consultant doctor of art history, Professor P. S. Volkova.

For citation: Putecheva O. A. The phenomenon and the semantics of sound in modern music as the subject of development in music education (based on works by Alexander Bakshi). Muzykal'noe iskusstvo i obrazovanie $=M u$ sical Art and Education, 2019, vol. 7, no. 1, pp. 107-119.

\section{Введение}

В современной системе музыкального образования, как в России, так и за рубежом, возрастает актуальность обращения к новейшим образцам композиторского творчества как отражению идей, ви́дений, концепций нашей действительности. Усложнение образности, новые, не- обычные средства выразительности требуют неординарного подхода к осознанию концептуальности произведений. В этом отношении особую роль играет формирование современных представлений о звуке, его существовании и звуковой среде произведения. Для изучения в музыкально-теоретическом и историче- 
ском аспектах новых произведений требуется знание особых техник звукоизвлечения, приёмов, усиливающих характеристичность отдельных звуков, ведущих к усилению их значительности и смыслов.

Освоение студентами авангардной музыки и её стилистических особенностей рассматривается в исследовании Б. Н. Лазарева [1]. Проблеме звуковой среды и роли звука в контексте обновления содержания музыкального образования посвящена статья А. А. Давыдовой и С. С. Лушникова [2]. Выводы музыкантов-педагогов становятся основой для дальнейшего рассмотрения проблем освоения обучающимися семантики звука в современных сочинениях, хотя этот аспект далеко не всегда выделен из общей проблематики включения современной музыки в образовательный процесс и требует отдельного рассмотрения.

В данном исследовании интерес к обозначенной проблеме обусловлен результатами изучения некоторых произведений Александра Бакши, применительно к творчеству которого сформировалось понятие «Театр звука». Для включения данного материала в образовательный процесс необходимо проследить становление этого уникального явления (Театр звука), а также выявить значение отдельного звука для звуковой организации сочинений, осознаваемых на основе новых параметров.

Задачи исследования вытекают из обозначенной цели, и их можно сформулировать следующим образом:

- уточнить возможности отдельно взятого звука как в плане выразительности, так и в содержательном аспекте;
- показать, что индивидуализация ведёт к усилению семантических свойств звука;

- доказать, что концентрация (интенсивность) смысловой нагрузки значительно увеличивается в условиях произведений действенного и сценического характера, где уже отдельно взятый звук выполняет определённую фоункцию.

Решение данных задач позволяет заложить основу для включения новейшей музыки в содержание музыкального образования.

\section{Современные музыкально- теоретические представления о феномене звука}

В современном музыкознании проблема звука и «звукосборки» произведения осознаётся как центральная, узловая, от неё протягиваются нити к целому кругу проблем. Движение от рассмотрения частного характера одного звука к его возможностям в произведении во взаимодействии с другими средствами художественного воздействия составляет методику анализа ряда инструментальных сочинений.

Онтологической основой существования музыкального произведения является звук, понимаемый как элементарная, мельчайшая единица музыкальной ткани. Что же представляет собой звук как фризическая величина, несёт ли он содержательную, смысловую нагрузку, способен ли выполнять фонкции в развитии произведения, как он связан с другими звуками, как устанавливаются звуковые связи и отношения, дающие представление о «звуковом поле» и «звуковом континууме»?

Говоря о звуке, часто имеют в виду некий звуковой атом в музыкаль- 
ном континууме, понимая его как простейший элемент, но так ли это? Сам звук осознаётся по преимуществу как материальная часть произведения, «материальное акустическое образование» (В. В. Медушевский [3, c. 10]), существующее наряду с образно-духовной составляющей. Однако, принимая во внимание современные исследования (И. В. Малышев [4] и др.), необходимо говорить о комплексном характере звука. Вызывает сомнение установка некоторых исследователей на акцентирование материальности и одномерности звука.

Звук с точки зрения фризики сложное явление, в котором происходит наложение гармоник, что уже на этом уровне создаёт объёмное звучание ряда обертонов.

В отличие от сформировавшихся ранее представлений о том, что семантической единицей музыкальной формы надо считать интонацию, мы приходим на основе анализа творчества А. Бакши к осознанию эволюции этого понятия.

Возможности звуковой выразительности постоянно расширяются: те явления, которые ранее не считались музыкальными, в настоящее время завоёвывают право находиться в сфере искусства. Пристальное внимание к отдельному звуку обусловило поиски сонорно-акустических эфрдектов, придающих особый смысл звуковой материи произведения.

На основополагающую роль отдельного звука указывают многие исследователи, давая определение понятию «музыка». Ю. Н. Бычков понимает музыку как «искусство звука» [5, с. 19]; близко к этому определению понимание музыки как искусства сочетания тонов. J. Blacking, представляя музыку как продукт поведения, называет её «человечески организованным звуком» [6, с. 116].

Аналогичное видение обнаруживается в работах В. В. Медушевского, который отмечает: «Уже единичный звук, взятый в совокупности всех его сторон - высоты, длительности, тембра, тесситуры, громкости, артикуляции, представляет собой знак - интонацию. Он может свидетельствовать о робости, уверенности, скованности или свободе, нежности или грубости» [3, с. 12].

Эту же мысль подчёркивает и М. Ш. Бонфельд, развивая её в работе «Музыка как мышление» и определяя музыкальное звучание как явление сложное, «многомерное нелинейное пространство» [7, с. 132]. Во всех определениях музыки как вида искусства есть нечто общее - то, что авторы в качестве первоосновы видят музыкальный звук. Звук не только материальная субстанция, способ передачи информации, но и смысл, транспонируемый энергетически на подсознательном уровне.

Порядок мироздания есть некая музыкальная гармония. Человек вписан в этот миропорядок, его жизнь должна быть созвучна всем природным явлениям, которые, по существу, являются колебательными. Акустические явления - часть жизни Вселенной. С помощью музыки устанавливается единство мира и человека - созвучие, симфония.

Как отмечают исследователи, начальным моментом создания произведения служит поиск исходного звука, в котором уже заложены важнейшие для композитора параметры. Данную мысль проводит В. Н. Холопова: «...Музыкальный язык был преобра- 
зован в XX веке столь фрундаментально, что строительство произведения стало вновь, как в ранние времена музыкальной письменности, начинаться с комбинаций одного звука с другим... более того - с создания самого исходного звука» [8, с. 50]. Аналогичную идею развивает И. И. Сниткова, подводя размышление к новой категории - «рактуре звука» [9, с. 11]. Внимание к отдельному звуку обусловливает появление характеристик воздействия звука и звуковых отношений. Мысль об особом статусе звука продолжает Т. В. Франтова: «...Пришёл новый критерий: относительность меры звукового напряжения, которое зависит и от интервального состава, и от иных свойств - фрактурной плотности, регистрового расположения, тембра, громкостной динамики» [10, c. 100]. Речь идёт о том, что основой воздействия является то напряжение, которое заложено в звучании, сам тон высказывания с его пониженной или повышенной энергией.

Весомость отдельной звуковой точки, рождающейся на пересечении смыслообразующих фракторов различного плана, позволяет считать каждый звук в музыкальном произведении семантически значимой единицей. Это обусловлено индивидуализацией звука в современном музыкальном языке, а также попыткой постижения глубинных устоев творчества композитора, идущего от осмысления характера отдельного звука, что и образует фрундамент самых авангардных поисков и решений.

Задаваясь вопросом, как возникает смысл уже на уровне отдельного звука, необходимо вспомнить об аналогиях, проводимых между жестом, пластикой, мимикой и музы- кой, то, что Асафьев назвал «немой интонацией». «Выход во внемузыкальное» [11, с. 3] конкретизирует смысловые поля произведения.

По мысли Л. В. Саввиной, индивидуализация звукоорганизации ведёт к трансформации музыкального языка и усложнению механизмов передачи музыкальной информации. Индивидуализация создаёт поле неопределённости, что служит основой усложнения семантической структуры передаваемого сообщения, возможности его многозначного прочтения. В творчестве многих современных композиторов событийность уплотняется, смыслом наполняются все меньшие музыкальные единицы. В настоящее время речь идёт об отдельном звуке. Звук становится настолько содержательной единицей, что, обретая смысловую глубину, вытесняет слово.

Решая проблему смыслового осознания звука, необходимо помнить, что музыкальное произведение - это не разрозненные тоны и звуки, а некая связь и система. Комплекс сочетаний звуков предполагает движение на более высокий уровень смысловой организации произведения в стремлении охватить «панзвуковое содержание» (термин Л. В. Саввиной. - О. П.) [12].

С этой точки зрения становятся понятны композиционные решения А. Бакши, где уровень обобщения достигает фрилософрской глубины, а произведение воспринимается как звуковая концепция.

\section{Театр звука Александра Бакши}

Композитор начинает работу с выработки характерных звуковых комбинаций, отдельных звуковых то- 
чек, для него важен звук как состояние. А. Бакши мыслит не интонациями и фразами, а отдельными точками-звуками. Уже на уровне отдельного звука закладывается не только эмоциональная доминанта восприятия, но смысловая координата. Как отмечает автор: «Всё, что звучит: стук вилки о тарелку, шорох бумаги, скрип половиц, - всё должно быть организовано ритмически, темброво, звуковысотно, смыслово. При этом важно - и должно - сопрягать партитуры пластического действия с партитурой звуков» (цит. по: [13, с. 137]).

Творческий замысел зачастую складывается как произведение непрограммное, без слов и вербализации; носителем смысла становится не фраза или интонация, а отдельный звук, в котором концентрируются смысловые векторы. Работа по созданию произведения и его концепции начинается с поиска звука, характера его звучания, тембра, что закладывает основы музыкального образа, кристаллизующегося на пересечении музыкальных звуков, подготовленных звуков, шумов, синтетических звучаний и человеческих голосов, утрачивающих своё вербальное начало. Бакши преодолевает понятийную природу слова, продвигаясь через звуки к глубинам подсознания, к сверхчувственному опыту.

В подобных приёмах происходит наслоение, уплотнение смыслов и усиление их суггестивных возможностей. Интенсивность, концентрация смыслов в единице музыкальной материи значительно возрастают в произведениях сценического жанра, где ответственность каждого звука выше, здесь каждый звук предельно содержателен, а благодаря этому вступает в диалог с текстовой и пластической линией спектакля.

Представление о равнозначности жеста, мимики, пластики, интонации, их взаимосвязи и формировании последующего из предыдущего обнаруживается в экспериментальных сочинениях и вырастает до метода. Приём передачи движения от жеста, телодвижения к тону, звуку встречаем во многих сочинениях: в музыкальной части спектаклей «Ещё Ван Гог», «Превращение», «Игры в инсталляциях», в мистерии «Полифония мира» и др. В этих случаях происходит наслоение, уплотнение смыслов и их суггестивных возможностей.

Внемузыкальные фракторы представлены такими источниками, как художественное высказывание посредством слова (литература) и художественное высказывание посредством изображения, представления. Гибкость и пластичность этих средств позволяют разнообразно их воплощать. Наряду с традиционными связями слова и музыки в вокально-инструментальных жанрах, присутствует и такое отношение к тексту, когда композитор лишь отталкивается от сюжета. Хорошо известный текст служит импульсом для музыкального решения, соприкасаясь с сюжетом отдельными точками или только на основе намёка развивая параллельную линию драматургии. Толчком для создания оригинального произведения может стать упоминание о какой-либо музыке, звучащих предметах, звуковой среде, месте действия, обрывок фрразы, отдельное многозначительное слово. «Звуковые» обстоятельства действий помогают композитору найти «ключевой тон», из которого вырастает 
произведение. Композитора привлекают «точки сбоя» в сюжете, драматургически переломные моменты, резкие трансформации, утрирование смысловых аспектов которых позволяет фрилософски осмысливать глубинные жизненные коллизии.

Другой тип внемузыкальных импульсов связан с изображением. В этом плане обнаруживается влияние балета, пантомимы, изобразительного искусства, скульптуры, хэппенинга. Здесь звук растёт из балетного движения или позы, поворота туловища или взгляда; толчком может стать росчерк кисти художника или красочное пятно на палитре, фрактура материала скульптуры, атмосфера места действия, объём пространства.

Всё это создаёт некое состояние души, которое и пытается переложить композитор на язык звуков. Его задача - уловить тончайшие вибрации әнергии и адекватно воплотить неуловимое в ощущаемые звуки, интонации, созвучия.

«Слышать видимое» (выражение С. Эйзенштейна $[11$, с. 25]) можно переосмыслить применительно к творчеству А. Бакши как «слышать невидимое» - в этом тонкость работы композитора.

Так внешние по отношению к музыке внемузыкальные факторы влияют на образование музыкально-художественных смыслов.

Особый уровень смыслопорождения связан с фракторами звуковыми, но не музыкальными, которые, однако, сообщают о месте действия, обстоятельствах, ситуации. Это сигналы, звонки, стрекотанье швейной машинки, стук колёс поезда, гудки, шарканье ног, хлопанье книг - всё это имеет обоснование на введение их в музыкальный контекст, обостряя внимание к смысловым параметрам звука. Для немузыкальных звуков А. Бакши находит специфические формы жизни и их обоснование в музыкальном произведении. В качестве примера можно вспомнить такое произведение, как «Сидур-мистерию», камерное инструментальное сочинение «Зима в Москве. Гололёд» и др. На данном уровне индивидуализации звуки создают яркие смысловые акценты, выстраивая драматургию произведения.

Интерес представляет художественное оформление и сочетание немузыкальных звуков с музыкальными в условиях сценического произведения. В качестве примера можно привести спектакль «Превращение» по мотивам произведения Ф. Кафрки, в котором центральной сценой становится «Ночь превращений». Предметы оживают, обретают свои голоса: перестук деревянных костяшек на бухгалтерских счётах, ритмичные удары метронома, звон колоколов, нежные переливы специально сконструированных музыкальных инструментов - овалоидов, звонок будильника, стук колёс поезда - всё это создаёт шумовую симфонию на фоне протяжно звучащих струнных.

Образование смысла также связано со способностью самой музыки передавать временны́е и пространственные параметры, основанные на ритме в узком и широком смысле, фактуре, сопоставлении высокого и низкого регистров.

Звукоорганизация произведений Бакши - многообразная, динамичная, чувствительная к ситуации привела к возникновению нового 
уникального явления - Театра звука, в котором главную роль играет звук. Одним из ярких примеров подобного плана произведений является уже упоминаемое ранее инструментальное произведение «Зима в Москве. Гололёд». Эфрфекта ощущения холода и льда композитор добивается, используя шуршаще-скрипящую окраску фрлажолетов у виолончели на фоне глиссандо по струнам рояля.

Уникальный пример Театра звука - инструментальное произведение под названием «Гамлет умирает». В образном отношении оно развивается как своеобразная сцена, которая начинается с гибели героя; в концептуальном плане конец является началом, а начало - это конец. Первые же такты произведения предстают фрактически как театр одного звука, в котором развитие строится исходя из ресурсов одного звука - pe третьей октавы. Аналогичный приём развития на звуке до обнаруживает параллель с необычным произведением И. Вышнеградского «Семь вариаций на ноту “до”» (1920). Композитор стремится доказать «возможность тембрового, ритмического, темпового, артикуляционного и агогического варьирования звучания лишь одной ноты» [14, с. 114].

Тема смерти - фрилософрская, она связана с предельной концентрацией внимания к одному состоянию застылости, последним вздохам, оцепенению. Композитор, отводя главную партию скрипке, в высказывании которой нет движения, нет жизни, а есть только повторение одного звука, использует минимум средств только ритм, окраску, динамику. Построение - даже не мелодия, а одно- единственное восклицание, основанное на риторической фигуре с форшлагом, подчёркивающим основной звук. Высокий звук ре третьей октавы издаётся на $p$ и развивается до $f$ с тормозящими фрерматами. Одинокий звук - не голос героя, но трепет души, покидающей тело. Музыкальная речь солирующей скрипки подчёркнуто разорвана паузами, ассоциативно отсылает к кадансовым завершающим формулам. Тончайшая работа на завершающих формулах становится ключом раскрытия смысла. Застылость как переход во вневременность ассоциируется со словами Гамлета «и в вечность перейду».

При полной свободе и кажущейся импровизационности наблюдается строгая организация, выражением которой становятся ритмически жёсткие шаги движущейся процессии музыкантов. Строго организован момент слома - конец начала и начало конца, выполненный в виде канонического шёпота инструменталистов: treason - предательство, измена.

Оттеняет суровую непреклонность речитативных интонаций раздел, следующий за сломом, в котором вторая, солирующая скрипка вначале робко, из-за кулис, затем на сцене вступает с танцевально-жанровой темой как воспоминанием или галлюцинацией.

Всё произведение строится на принципе обретения интонации: движение от одного звука к возникновению и осмыслению двузвучия, дающегося в трудной кристаллизации и преодолении статики. С огромным трудом звуковой диапазон расширяется. Смысл формируется в энергетическом расширении звукового объёма, в противопоставлении звука 
и пауз, обнаруживающих аналогии с дыханием, в особенностях построения динамики - не затухающей, а нарастающей. Концепция произведения осознаётся как преодоление смерти и рост жизненных элементов.

Семантические аспекты музыки усиливаются в использовании немузыкальных средств театрального характера, связанных с действием и театральным перемещением по сцене. Это способствует расширению ассоциативности мышления, индивидуализации звуковой среды и расширению открывающихся смыслов произведения.

\section{Заключение}

Резюмируя способы работы с внемузыкальными импульсами, рождающими произведение, можно сформулировать несколько принципов: принцип транспонирования; принцип толчка, импульса; принцип смысловых вибраций.

Работа со звуком, звуковые трансформации усложняют код смыслопорождения, что ведёт к изменению типа коммуникации. В связи с «визуальным поворотом» вырабатываются новые типы кодов, расширяющих смысловые границы. Процессы децентрации в интертекстуальных взаимодействиях способствуют проникновению специфических кодов других систем (видов искусства). Ре- зультатом взаимодействия становится возможность существования в одном произведении нескольких художественных кодов звукоорганизации, преображающих произведение в многоуровневую иерархическую систему. Множественность кодов создаёт объёмность его восприятия в полисемантическом целом.

Понимание фрилософской глубины звуковых отношений, выстраивание произведения в виде звуковой концепции приводит к феномену Театра звука, в котором тончайшие нюансы работы тембрового, ритмического, темпового, артикуляционного и агогического характера создают уникальные значения и смыслы. Анализ конкретных музыкальных решений позволяет чутко реагировать на изменения, происходящие в культуре, не просто запечатлевать звуковые сдвиги, но и отфильтровывать всё ценное. Открытие новых феноменологических, семантических фракторов ведёт к обновлению содержательности музыкального искусства. Данный аспект необходимо учитывать, а следовательно, включать в содержание музыкального образования, чтобы оно сохраняло свою актуальность в эпоху стремительных перемен и обеспечивало неразрывную связь теоретических представлений с творческой практикой.

\section{БИБЛИОГРАФИЯ}

1. Лазарев Б. Н. Подготовка студентов к освоению стилистических особенностей авангардной музыки // Вестник кафедры ЮНЕСКО «Музыкальное искусство и образование». 2013. № 2 (2). C. 94-98.

2. Давыдова А. А., Лушников, С. С. Современная музыка и её место в образовательном процессе музыкально-педагогических вузов и факультетов // Учёные записки Российского государственного социального университета. 2017. Т. 16, № 4 (143). С. 102-109. 
3. Медушевский В. В. О закономерностях и средствах художественного воздействия музыки. М.: Музыка, 1976. 254 с.

4. Мальшев И. В. Хронотоп музыкального произведения // Музыкальное произведение: эстетический анализ. М.: Изд-во Российской академии музыки им. Гнесиных, 1999. 91 c. URL: https://www.proza.ru/2010/03/09/1185 (дата обращения: 01.11.2018).

5. Бычков Ю. Н. Понятие «Музыка». Периодизация становления и развития музыкального искусства // Вопросы музыкознания. Теория. История. Методика. Вып. III. МГИМ им. А. Г. Шнитке. М., 2010. С. 9-26. URL: http://yuri317.narod.ru/st/ponmus.htm (дата обращения: 01.11.2018).

6. Blacking J. How musical is man? University of Washington Press, Seattle, USA, 1973. 116 p. ISBN 0-295-95338-1. URL: https://en.wikipedia.org/wiki/John_Blacking (дата обращения: 01.11.2018).

7. Бонфельд М. Ш. Музыка как мышление // Бонфельд М. Ш., Волкова П. С., Казанцева Л. П., Шаховский В. И. Музыка начинается там, где кончается слово. Астрахань; М.: Изд-во НТЦ «Консерватория», 1995. С. 129-203.

8. Холопова В. Н. Типология музыкальных форм второй половины XX века (50-80-е годы) // Проблемы музыкальной формы в теоретических курсах вуза : сб. трудов РАМ им. Гнесиных. Вып. 132. М., 1994. С. 46-69.

9. Сниткова И. И. О новых принципах фактурной организации в современной музыке: автореф. дис. ... канд. искусствоведения. Вильнюс, 1986. 22 с.

10. Франтова Т. В. Полифония А. Шнитке и новые тенденции в музыке второй половины XX века. Ростов н/Д: Изд-во СКНЦ ВШ АПСН, 2004. 404 с.

11. Курышева Т. А. Театральность и музыка. М.: Советский композитор, 1984. 200 с.

12. Саввина Л. В. Звукоорганизация музыки $\mathrm{XX}$ века как объект семантики: автореф. дис. ... д-ра искусствоведения. Саратов, 2009. 43 с.

13. Партитуры двух спектаклей. Нумер в гостинице города NN. Превращение $=$ Scores for two plays / под общ. ред. В. Семеновского; запись партитуры Л. С. Бакши. М.: Изд-во Творческого центра им. Вс. Мейерхольда (при содействии Daimler Chrysler), 1999. 144 с.

14. Петров В. О. Четвертитоновая композиция в жанре фортепианного дуэта ХХ века // Художник и время: феномен восприятия интертекстуальности в искусстве: сб. материалов науч.практ. конференции. Вып. 1. Краснодар; Геленджик: Изд-во КГУКИ, 2004. С. 113-119.

Поступила 10.12.2018; принята к публикации 15.03.2019.

\section{Об авторе:}

Путечева Ольга Анатольевна, доцент кафедры общественных наук и организации здравоохранения Некоммерческого образовательного частного учреждения высшего образования «Кубанский медицинский институт» (ул. Будённого, 198, Краснодар, Российская Федерация, 350015), кандидат искусствоведения, putecheva.olga@mail.ru

Авторол прочитан и одобрен окончательный вариант рукописи. 


\section{REFERENCES}

1. Lazarev B. N. Podgotovka studentov k osvoeniyu stilisticheskikh osobennostej avangardnoj muzyki [Preparation of students for the development of stylistic features of avant-garde music]. Vestnik kafedry UNESCO "Muzykal'noe iskusstvo i obrazovanie" = Bulletin of the UNESCO Chair “Musical Arts and Education", 2013, no. 2, pp. 94-98 (in Russian, abstract in English).

2. Davydova A. A., Lushnikov S. S. Sovremennaya muzyka i ee mesto v obrazovatel'nom processe muzykal'no-pedagogicheskikh vuzov i fakul'tetov [Modern music and its place in the educational process of musical and pedagogical universities and faculties]. Uchyonye zapiski Rossijskogo gosudarstvennogo social'nogo universiteta Scientific notes of the Russian State Social University, 2017. Vol. 16, no. 4 (143), pp. 102-109 (in Russian).

3. Medushevsky V. V. O zakonomernostjakh i sredstvakh khudozhestvennogo vozdejstvija muzyki [About regularities and means of artistic influence of music]. Moscow: Muzyka Publ., 1976. 254 p. (in Russian).

4. Malyshev I. V. Khronotop muzykal'nogo proizvedeniya [Chronotope of a musical work]. Muzykal'noe proizvedenie: esteticheskij analiz [Piece of music: an aesthetic analysis]. Moscow: Russian Gnesins Academy of Music Publ. 91 p. (in Russian).

5. Bychkov Yu. N. Ponyatie "Muzyka". Periodizatsiya stanovleniya i razvitiya muzykal'nogo iskusstva [The Concept of "Music". Periodization of formation and development of musical art]. Voprosy muzykoznaniya. Teoriya. Istoriya. Metodika [Problems of Musicology. Theory. History. Method]. Issue III. Moscow State Institute of Music named after Alfred Schnittke. Moscow, 2010, pp. 9-26. Available at: http://yuri317.narod.ru/st/ponmus.htm (accessed: 1 November 2018) (in Russian).

6. Blacking J. How musical is man? University of Washington Press, Seattle, USA, 1973. 116 p. ISBN 0-295-95338-1. Available at: https://en.wikipedia.org/wiki/John_Blacking (accessed: 1 November 2018).

7. Bonfel'd M. Sh. Muzyka kak myshlenie [Music as thinking]. Bonfel'd M. Sh., Volkova P. S., Kazantseva L. P., Shakhovsky V. I. Muzyka nachinaetsya tam, gde konchaetsya slovo [Music begins where the word ends]. Astrakhan'; Moscow: STC "Konservatoriya" Publ., 1995, pp. 129-203 (in Russian).

8. Kholopova V. N. Tipologiya muzykal'nykh form vtoroj poloviny XX veka (50-80-e gody) [Typology of musical forms of the second half of the twentieth century (50-80 yeas)]. Problemy muzykal'noj formy v teoreticheskikh kursakh vuza [Problems of musical form in theoretical courses higher educational institution]: collection of scientific works of the Russian Gnesins Academy of Music. Issue 132. Moscow, 1994, pp. 46-69 (in Russian).

9. Snitkova I. I. O novykh printsipakh fakturnoj organizatsii v sovremennoj muzyke [About the new principles of texture organization in modern music]. Extended abstract of $\mathrm{PhD}$ dissertation (Arts). Vilnius (Lithuania), 1986. 22 p. (in Russian).

10. Frantova T. V. Polifoniya A. Schnittke $i$ novye tendentsii v muzyke vtoroj poloviny XX veka [A. Schnittke's polyphony and new trends in music of the second half of the twentieth century]. Rostov-on-Don: SKNTS VSH APSN Publ., 2004. 404 p. (in Russian).

11. Kurysheva T. A. Teatral'nost' $i$ muzyka [Theatrics and music]. Moscow: Sovetskij kompozitor Publ., 1984. 200 p. (in Russian).

12. Savvina L. V. Zvukoorganizatsiya muzyki XX veka kak ob'ekt semantiki [Sound organization of music of the XX century as an object of semantics]. Extended abstract of Doctoral dissertation (Arts). Saratov, 2009. 43 p. (in Russian). 
13. Bakshi L. S. Partitury dvukh spektaklej. Numer v gostinitse goroda NN. Prevrashchenie [Scores for two plays. Hotel Room in Town N. The Metamorphosis]. Under general editorship of V. Semenovsky. Author of the play score record L. Bakshi. Moscow: Tvorcheskij tsentr im. Vs. Meyerhol'da Publ.: Daimler Chrysler, 1999. 144 p. (in Russian; in English).

14. Petrov V. O. Chetvertitonovaya kompozitsiya v zhanre fortepiannogo dueta XX veka [Quaternary composition in the genre of piano duet of the XX century]. Khudozhnik $i$ vremya: fenomen vospriyatiya intertekstual'nosti $v$ iskusstve [Artist and time: the phenomenon of perception of intertextuality in art]: collection of proceedings of the scientific-practical conference. Issue 1. Krasnodar; Gelendzhik: KGUKI Publ., 2004, pp. 113-119 (in Russian).

Submitted 10.12.2018; revised 15.03.2019.

About the author:

Olga A. Putecheva, Associate Professor at the Department of Social Sciences and Healthcare Organizations, Non-profit Private Educational Institution of Higher Education "Kuban Medical Institute" (Budennogo Street, 198, Krasnodar, Russian Federation, 350015), PhD Art History, putecheva.olga@mail.ru

The author has read and approved the final manuscript. 


\section{ОСОБЕННОСТИ РЕАЛИЗАЦИИ}

\section{ИНТОНАЦИОННОГО ПОДХОДА В КУРСЕ ФОЛЬКЛОРНОГО СОЛЬФЕДЖИО НА ПРИМЕРЕ РУССКОЙ ТРАДИЦИОННОЙ КУЛЬТУРЫ}

\section{О. В. Пивницкая,}

Московский педагогический государственный университет (МПГУ), Москва, Российская Федерация, 119991

Аннотация. $B$ предлагаелой статье речь идёт о иелесообразности и перспективности разработки интонационного подхода к освоению учебного материала на уроках ббольклорного сольфбеджио. Как известно, музыкальное образование народной ориентации в России илеет многовековую историю. При этол песенный фбольклор всегда был и остаётся неотьеллелой частью отечественной и мировой музыкальной культуры. В ходе исторической эволюиии отечественной музыкальной фбольклористики выделились и одборлились два направления: первое характеризуется расслотрениел её как единой логической систель, второе связано с выявлениел характерных особенностей русской народной музыки в различных регионах. В основных подходах к обучению народнолу пению такюе можно выделить два магистральных направления, которые условно принято обозначать как аутентичное и сиеническое. В русле аутентичного направления прослеживаются две салостоятельные тендениии, характерные для исполнения народных песен. Первая предполагает освоение народной песни вне направленности на углублённое изучение какой-либо одной или нескольких региональных традииий, вторая илеет чёткую направленность на освоение учащилися какой-либо конкретной народно-песенной традиции. Проведённый анализ позволяет также вылелить два основных направления в трактовке народно-песенного материала, сложившихся в педагогике музыкального образования: первое характеризуется расслотрениел народнопесенных образиов в качестве материала для сольбеджирования, второе расслотрениел народньх песен как салостоятельной художественной иенности. Поскольку основной иелью фбольклорного сольбеджио является развитие этнослуха и этноинтонирования, учебньй материал курса должен быть выстроен с учётол различных подходов $\kappa$ его освоению. Так, в учебнол материале, предназначеннол для изучения русского песенного материала в русле сиенического направления, улестно использование песенных прилеров в основнол в виде инварианта, в то вреля как для аутентичного направления в содержание образования должны включаться преилущественно прилеры с вариативной составляющей. 
Ключевые слова: музыкальное образование, стилевое сольббеджио, народно-песенная традиция, ббольклорное сольбеджио.

Благодарности: Данная статья выполнена в контексте научной работы кафбедры методологии и технологий педагогики музыкального образования Института изяшных искусств Московского педагогического государственного университета.

Для цитирования: Пивницкая O. B. Особенности реализации интонационного подхода в курсе фольклорного сольфеджио на примере русской традиционной культуры // Музыкальное искусство и образование. 2019. T. 7. № 1. C. 120-131.

\title{
THE PECULIARITIES OF INTONATIONAL APPROACH REALIZATION WITHIN THE COURSE OF FOLK SOLFEGGIO BASED ON RUSSIAN TRADITIONAL CULTURE
}

\section{Olga V. Pivnitskaya,}

Moscow Pedagogical State University (MPGU), Moscow, Russian Federation, 119991

\begin{abstract}
The given article touches upon reasonability and perspectivity of the development of intonation approach to the mastering of learning material at folk solfeggio lessons. As is known folk-oriented musical education has a long history in Russia. Meanwhile song folklore has always been an integral part of national and world music culture. During the historical revolution two trends in national ethnomusicology have developed. The first one is studied as a consistent logical system while the second one is connected with the detection of unique features of Russian folk music in different regions. The two main trends can be noted in the basic approaches to the mastering of folk singing and they are designated as authentic and scenic. Within the frameworks of the authentic trend there are two independent trends specific for folk singing. The first one implies the mastering of folk singing without in-depth study of one or several regional trends and the second one is aimed at studying of any specific folk-song tradition by students. The conducted analysis gives ground to extract two basic trends that have developed in musical education pedagogy where the first one takes folk-song examples as solfeggio materials and the second one studies folk songs as independent artistic value in folk-song material rendering. Minding the fact that the main goal of folk solfeggio is to develop ethnical hearing and ethnical intonation, learning material should mind different approaches to its mastering. So the learning material aimed
\end{abstract}


at mastering of Russian song material within the scenic trend should include song examples mainly as invariants while for the authentic one there should mainly be the examples with a variative component.

Keywords: music education, style solfeggio, folk-song tradition, folk solfeggio.

Acknowledgements: This article was designed in the context of the research for the Department of Methodology and Technology of the Music Education at the Moscow Pedagogical State University (MPGU).

For citation: Pivnitskaya O. V. The peculiarities of intonational approach realization within the course of folk solfeggio based on Russian traditional culture. Muzykal'noe iskusstvo $i$ obrazovanie = Musical Art and Education, 2019, vol. 7, no. 1, pp. 120-131.

\section{Введение в проблему}

Музыкальное образование народной ориентации в России насчитывает многовековую историю. По мнению исследователей, в народном творчестве можно выделить две основные сферы: фольклор, представленный песнями и инструментальной музыкой, и менестрельную традицию, являющуюся составной частью искусства скоморохов [1, с. 148]. В фокусе нашего внимания - песенный фрольклор России с учётом его многообразия, присущего многонациональной стране, что предполагает включение в содержание образования не только русской, но также региональных и даже локальных его разновидностей.

Известно, что из всех видов вокальной речи народное пение является самым древним искусством. Обладая огромным эмоциональным и нравственным потенциалом, песенный фольклор всегда был и остаётся неотъемлемой частью отечественной и мировой музыкальной культуры. Согласно определению, данному И. И. Земцовским, он пони- мается прежде всего как музыкально-поэтическое искусство, создаваемое и передаваемое каждой этнической средой из поколения в поколение. Фундаментальные исследования Б. В. Асафььева [2], В. В. Медушевского [3], И. И. Земцовского [4], Л. В. Шаминой [5] показали, что национальные интонационные системы прошли длительный путь своего становления, формирования и эволюционного отбора и, по сути, являются музыкой, отражающей возможности звукового сознания народа. При этом каждая музыкальная культура имеет свой музыкальный язык, свои национальные черты, которые и создают самобытность, неповторимость и своеобразие народного музыкального стиля, его интонационный «словарь», структурные стереотипы. Именно они и являются принципиальной основой устного песенного творчества.

На сегодняшний день в России насчитывается множество фольклорных школ, студий, центров, немало и фольклорных отделений в творческих вузах. Все они испытывают острую потреб- 
ность в учебниках и методических пособиях по фольклорному сольреджио. При достаточном количестве разнообразных сборников песенных примеров из российского фольклора специальных учебников по фольклорному сольфеджио по-прежнему очень мало. Среди немногочисленных примеров подобных учебников - «Русские народные песни. Сборник для чтения с листа в курсе сольфеджио» К. В. Бромлей и Н. С. Темериной [6] и «Этносольфеджио на материале традиционной песни русской деревни» М. А. Лобанова [7], причём и в них не ставится задача углублённого изучения какихлибо региональных традищий. Кроме того, можно указать на комплект пособий автора данной статьи «Школа фольклорного сольфеджирования» [8], посвящённый освоению народно-песенной традиции среднерусского региона России.

При этом следует заметить, что, поскольку основной целью фрольклорного сольфеджио является не освоение традиции, а развитие этнослуха и этноинтонирования, учебный материал курса должен быть выстроен с учётом соответствующих подходов к его освоению, в которых будет учитываться целевая направленность обучающихся на постижение этноинтонационной природы народной традиции в соответствии с их ориентацией на свою будущую деятельность в сфере народной культуры и образования.

\section{Русский песенный фольклор как предмет освоения в курсе фольклорного сольфеджио}

Как указывает А. В. Руднева [9], на протяжении веков возникали различные жанрово-стилевые пласты музыкального фрольклора, которые затем, переживая стадию своего существования, достигали расцвета и стабилизации выработанных форм. Каждый последующий этап развития традиционной культуры не отвергал возникшее ранее, а сохранял и постоянно наращивал его объём. Таким образом, можно сделать вывод: русский фольклор не только прошёл те же стадии (древнерусскую - великорусскую - национально-русскую), что и этнос, но и донёс до нас значительную часть культурного наследия эпохи восточнославянской общности.

Территориальный фрактор особенно актуален для русского фрольклора, так как славяне постепенно осваивали огромные территории, продвигаясь сначала на север и северо-восток, до берегов северных морей, затем на юг и восток - в южнорусские степи, а также на Волгу, к Уралу и далее в Сибирь. Одна из важнейших особенностей русской этнокультурной истории - непрерывный процесс образования всё новых локальных групп русского населения. Этот процесс не прекращался вплоть до начала $\mathrm{XX}$ века, в результате чего возникали локальные варианты русской традиционной культуры.

Анализируя труды таких исследователей, как В. М. Щуров [10], Л. В. Шамина [11], В. А. Лапин [12], мы, опираясь на исторический и этнографический аспекты, можем выделить фрольклорные традиции разных областей. Особенности исполнительской манеры того или иного региона чаще всего зависят от функциональности народно-песенного фольклора и условий его бытования (в доме, на улице и т. д.). Например, обрядовые 
песни принято петь громко, «уличным» звуком; лирические - тихо и нежно, светло и легко; эпические произведения - в речитативном стиле с эмоциональной экспрессией и т. п.

Общеизвестно, что каждый регион обладает своей уникальностью и неповторимостью. Место, где родился и вырос человек, принятые там порядки и обычаи, язык с региональными диалектами и интонациями все эти фракторы играют решающую роль в формировании исполнительской манеры народно-песенного фольклора, которую принято называть народной манерой. Среди её характерных признаков следует отметить специфическое звукоизвлечение, открытый способ голосообразования, речевую манеру голосоведения, близкий звук, использование специфических приёмов («скольжение», «подъезды», глиссандо, «словообрыв» и др.), небольшой диапазон, однорегистровое звучание преимущественно в грудном регистре с ограниченным использованием головного звучания, местный диалект с сохранением исторически сложившегося говора и т. п.

Необходимо подчеркнуть, что в ходе эволющии в отечественной музыкальной фольклористике оформились два направления в изучении песенного ббольклора. Первое из них характеризуется расслотрениел его как единой логической системыь. Рождение второго направления связано с появлением звукозаписывающей аппаратуры, с помощью которой исследователи народного музыкального творчества обнаружили, по образному выражению В. А. Лапина, «его чисто звуковую непохожесть» [12]. Как следствие, в этнофрольклори- стике возрастает интерес учёных к выявлению характерных особенностей русской народной музыки в различных регионах.

Проблема сохранения традиций русского песенного фольклора со всей остротой была поставлена Б. В. Асафьевым, который отмечал, что «...песня уходит. Её интонация теряется. <..> Вымирают носители исконных песенных традиций» [13, с. 168]. В этом отношении для ориентации обучающихся в этноинтонационной природе изучаемой традиции, в особенностях её проявления в разных историко-стилевых пластах и жанрах миссия курса сольфеджио видится именно в интонационнол подходе к освоению учебного материала.

Первоначально по пути, намеченному Б. В. Асафььевым в деле собирания и изучения русской песни, пошли немногие музыковеды-фольклористы. Первым среди них следует упомянуть А. Д. Григорьева с его собранием северно-русских былин, записанных на фонографр. В сборниках исследователя впервые в русской фольклористике представлены песни одного жанра, ограниченные одним ареалом [14]. Эту тенденцию подхватили Е. В. Гиппиус и З. В. Эвальд, которые в своём фундаментальном труде «Песни Пинежья» представили богатый песенный материал данной локальной народно-песенной традиции [15]. Несколько позже исследования в этом направлении были продолжены А. В. Рудневой [16].

Приблизительно с 70-х годов прошлого столетия интерес исследователей к локальным фольклорным традициям и стилям становится всё более ярко выраженным. На изучение стилистических особенностей русской 
народной песни различных регионов направлены усилия этномузыкологов Н. Н. Гиляровой [17], В. М. Мехнецова [18], С. И. Пушкиной [19], Н. М. Савельевой [20], В. М. Щурова [10] и ряда других исследователей. Показательно в этом отношении высказывание В. М. Щурова: «Важную роль в последнее время приобретает... изучение местной стилистики музыкального фольклора, выяснение различий в характере народного творчества разных районов и областей России» (цит. по: [7, с. 110]).

Результаты проведённых в этой сорере исследований привели учёных к новому пониманию народной культуры, которая, как подчёркивается сегодня многими фольклористами, не существует вне территориально конкретных традиций [10; 12 и др.]. Иными словами, фольклорная традиция любого народа характеризуется сосуществованием множества различных региональных традиций. Каждой из них присущ внутренний динамизм, проявляющийся в постоянной борьбе между устойчивостью (сохранение определённых формул) и изменчивостью (вариативность).

Следует отметить, что и обучение народному пению в зависимости от конечной его цели осуществляется по-разному. В одних случаях оно будет ориентировано на аутентичное исполнение, в других - на сценическое. Более того, даже в русле аутентичного направления можно обнаружить две самостоятельные тенденции, характерные для исполнения народных песен.

Так, одна из них предполагает освоение народной песни вне направленности на углублённое изучение какой-либо одной или не- скольких региональных традиций. Зерном данной концепции является освоение учащимися народно-песенного наследия без учёта специфики народно-песенного интонирования, но в народной манере звукоизвлечения [24, с. 12].

Вторую тенденцию в обучении народной манере пения в русле аутентичного направления отличает нацеленность на освоение учащимися какой-либо одной народно-песенной традиции. Данный подход приобретает в трудах отечественных педагогов-музыкантов особое значение ввиду наличия в России большого числа фольклорных традиций со своими, только им присущими стилевыми особенностями.

В свою очередь, различные подходы к освоению народно-песенного материала диктуют логику его выстраивания в учебном курсе фольклорного сольфеджио. Так, в учебном материале, предназначенном для изучения русского песенного материала в русле сценического направления, не предполагающего освоения региональных традиций, будет уместным использование песенных примеров в основном в виде инварианта, без учёта многовариантной природы традиционного фольклора, в то время как для аутентичного направления характерно включать в содержание образования преимущественно примеры с вариативной составляющей.

Исследователи народного творчества неоднократно обращались к вопросу постановки народной манеры пения. Изучение данной проблемы показало, что многие вопросы до сих пор нуждаются в подробном объяснении и развёрнутом обосновании. На 
сегодняшний день проблемы вокальной методики сольного народного пения остаются в зоне пристального внимания вокалистов. Выпускаются работы, посвящённые её рассмотрению, исследователи освещают данную тему в своих трудах.

Как утверждает Е. В. Баклыкова [21], народная песня и народная манера пения, наряду с языком этноса, являются важнейшими составляющими русской народной культуры. В этом её поддерживает В. И. Байтуганов [22], отмечая, что наиболее ярко особенности этноса проявляются в речи, интонации, а речевые интонации, выраженные через попевки, звуковые образы, по мнению исследователя, составляют суть народной манеры пения. Подобные мысли мы встречаем и у Н. В. Калугиной. Согласно её определению, «народная манера пения - это целый комплекс вокально-исполнительских средств и приёмов, сложившихся на основе местных историко-культурных и художественных традиций под воздействием бытовой певческой среды» [23]. Таким образом, данная исполнительская манера в своей основе имеет особенности диалекта, музыкального языка и исполнительского опыта народных певцов какой-либо одной конкретной местности. Искусство традиционного пения во все времена передавалось из поколения в поколение.

Каждая региональная традиция русского песенного фольклора, как известно, имеет свои интонационные комплексы с характерными для неё типами мелодики, ритмики, ладовыми структурами, особенностями строфической организации и т. д. Таким образом, постижение любой из них как обя- зательное предполагает вхождение учашихся в её интонационный строй, проникновение в сушностные особенности многовариантной природь народно-песенного интонирования.

\section{Развитие этноинтонационого слуха} и навыков этноинтонирования в сольфеджийной подготовке исполнителей песенного фольклора

Независимо от используемого подхода к изучению фольклора, учащиеся нуждаются в соответствующей сольфеджийной подготовке, которая, опираясь на общую базу, будет различной с учётом адресной направленности и цели изучения данного учебного предмета.

Прежде всего хотелось бы отметить то общее, что будет объединять разные подходы к обучению, а именно формирование у учащихся базового попевочного фонда, характерного для конкретного этноса в целом. Главное на этом этапе - первоначальное накопление будущими певцами этнослуховых представлений, обогащение их этноинтонационного фонда и опыта этноинтонирования, для чего в содержание образования следует включать несложные типовые напевы, свойственные календарным и игровым жанрам, таким как колядки, подблюдные песни, веснянки, хороводы и игровые песни. При этом будет происходить ознакомление учащихся с особенностями применения типичных для песенной культуры этноса попевок и напевов в разных жанровых контекстах и формирование у них так называемого попевочного мышления.

В дальнейшем, в зависимости от подхода к обучению народному пению - сценическому или аутентен- 
тичному, сольфеджийная подготовка обучающихся будет осуществляться по-разному.

Так, для будущих певцов сиенического направления основной акцент в обучении должен делаться на освоении песенных примеров наиболее типичных для «общерусского» стиля без учёта интонационных, диалектных и прочих особенностей, свойственных какой-либо региональной традиции. В работе над диктантом нотная запись должна преобладать над устным воспроизведением. Слуховой анализ рекомендуется осуществлять на примерах с использованием натуральных ладов.

Для исполнителей фольклора, работающих в русле аутентичного направления, в содержании образования необходимо предусматривать последовательное развитие этноинтонационного слуха учащихся посредством целенаправленного расширения их музыкально-слуховых представлений о типичных интонационных комплекcax, нашедших воплощение в народно-песенной культуре какой-либо определённой региональной традиции в широком жанровом диапазоне, с характерными для каждого из них интонационными, ладовыми и ритмическими особенностями, овладение типичными для изучаемой традиции ладомелодическими и метроритмическими попевками. В работе над диктантом целесообразно преобладание устного воспроизведения материала над письменным, что заложено в самой природе народного исполнительства. Особо следует отметить творческое воссоздание учащимися собственных вариантов распева типовых напевов в рамках песенного фольклора изучаемого региона.
Музыкальный материал для освоения учащимися должен быть подобран с учётом общедидактических принципов. Таким образом, в содержание образования необходимо включать характерные мелодические обороты, ладовые структуры, типы песенного стихосложения и строфической организации.

Результаты проведённого нами анализа воззрений педагогов-музыкантов на интонационно-слуховое и певческое освоение учащимися народно-песенного творчества в учебном курсе сольфеджио дают основания выделить два основных направления в трактовке народно-песенного материала, сложившиеся в методике преподавания этой дисциплины.

Первое направление характеризуется рассмотрением народно-песенных образцов исключительно как материала для сольфеджирования. Тем самым народные песни выполняют в учебно-образовательном процессе главным образом вспомогательную дидактическую фрункцию: способствуют расширению интонационно-слуховых представлений учащихся и не имеют самостоятельной художественной ценности. При этом предусматривается традиционная трактовка как нотного, так и словесного текста, заключающаяся в разучивании и воспроизведении народных песен в полном соответствии с нотной записью.

Второе направление в трактовке народно-песенного материала в курсе сольфеджио отличается рассмотрением народных песен как самостоятельной художественной ценности. В данном случае на первое место выходит постижение учащимися интонационной природы на- 
родной песни, её многовариантности, раскрытие художественного образа и средств художественной выразительности, присущих народной музыкальной культуре.

В свою очередь, в русле этого направления можно выделить два основных подхода к народным песням как учебному материалу.

Так, первый подход предполагает освоение народной песни вне направленности на углублённое изучение какой-либо одной или нескольких региональных традиций, в то время как второй подход к рассмотрению народных песен в качестве учебного материала, имеющего самостоятельную художественную ценность, отличается направленностью образования на освоение учащимися какой-либо одной конкретной народно-песенной традиции.

Таким образом, принимая во внимание историческое развитие педагогических систем обучения песенному фрольклору в нашей стране, имеющиеся на сегодняшний день учебные пособия для фольклорного сольреджио целесообразно разделить на две группы, одна из которых предполагает преобладание инвариативной составляющей, а другая вариативной.

В контексте первого направления освоения песенного фольклора учащимися целесообразно предложить учебные пособия с народно-песенными образцами, выбранными без учёта характерных особенностей какой-либо региональной традиции.

В связи с тем, что второе направление включает в себя два разных подхода к освоению отечественного песенного фольклора, подбор дидактического материала для фольклорного сольфеджирования также будет ориентирован на специфику его постижения. Учитывая концепцию этнослуха, предложенную И. И. Земцовским [4], учебные пособия должны содержать преимущественно песенные примеры с вариативной составляющей, причём в меньшей мере для подхода к освоению песенного фольклора вне направленности на углублённое изучение региональной традиции, и в большей - для углублённого подхода $к$ освоению конкретной региональной традиции и её локальных разновидностей.

\section{БИБЛИОГРАФИЯ}

1. Николаева Е. В. История музыкального образования. Древняя Русь. М.: Владос, 2003. 208 с.

2. Асафьев Б. В. Музыкальная форма как процесс. Л.: Музыка, 1971. 376 с.

3. Медушевский В. В. Интонационная форма музыки: Исследование. М.: Композитор, 1993. 265 с.

4. Земиовский И. И. Апология слуха // Музыкальная академия. 2002. № 1. С. 1-12.

5. Шамина Л. В. Этнографическая парадигма школьного музыкального образования: от «этнографии слуха» к музыке мира // Преподаватель. 2002. № 6. С. 21-27.

6. Бромлей К. В., Темерина Н. С. Русские народные песни: сборник для чтения с листа в курсе сольфеджио. М.: Музыка, 1972. 239 с.

7. Лобанов М. А. Этносольфеджио на материале традиционной песни русской деревни. СПб.: Северный олень, 1996. 74 с.

8. Пивницкая О. В. Школа фольклорного сольфеджирования. Вып. 1. М.: Композитор, 2001. 92 с.; Вып. 2. М.: Композитор, 2002. 131 с. 
9. Руднева А. В. Русское народное музыкальное творчество. М.: Композитор, 1994. 224 с.

10. Щуров В. М. О региональных традициях в русском народном музыкальном творчестве // Музыкальная фольклористика. Вып. 3. М.: Советский композитор, 1986. С. 11-47.

11. Шамина Л. В. Школа русского народного пения. М.: Изд-во Московского государственного фольклорного центра «Русская песня» ВМО, 1997. 88 с.

12. Лапин В. А. Русский музыкальный фольклор и история. М.: Изд-во Московского государственного фольклорного центра «Русская песня», 1995. $200 \mathrm{c}$.

13. Асафьев Б. В. Русская народная песня и её место в школьном музыкальном воспитании и образовании // О хоровом искусстве: сб. статей / сост. и коммент. А. Павлова-Арбенина. Л.: Музыка, 1980. С. 167-178.

14. Архангельские былины и исторические песни, собранные А. Д. Григорьевым в 1899 1901 гг.: с напевами, записанными посредством фонографа: в 3 т. Т. 1. Ч. 1. Поморье. Ч. 2. Пинега. М.: Изд-во Императораторской академии, 1904. 705 с.

15. Гиппиус Е. В., Эвальд 3. В. Песни Пинежья. М.: Музгиз, 1937. 584 с.

16. Руднева А. В. Народные песни Московской области. М.: Музыка. 1964. 115 с.

17. Гилярова Н. Н. Музыкальный фольклор Рязанской области. Рязань: Изд-во Рязанского областного центра народного творчества, 1994. 194 с.

18. Мехнецов A. М. Традиция как основополагающий принцип народной музыкальной культуры // Русская народная песня. Стиль, жанр, традиция: сб. науч. статей / ред.-сост. А. М. Мехнецов. Л.: Изд-во ЛОЛГК имени Н. А. Римского-Корсакова, 1985. С. 5-18.

19. Пушкина С. И. Русские народные песни Московской области. Вып. 2. М.: Советский композитор, 1988. $336 \mathrm{c}$.

20. Савельева Н. М. О региональных и локальных разновидностях типовых русских песенных структур // Проблемы композиции народной песни: науч. труды Московской государственной консерватории. М., 1977. С. 41-70.

21. Баклыкова E. В. Народная манера пения. Основные принципы. URL: http://www.rnd-sale.ru/ baklykova-elena-narodnaya-manera-peniya-osnovnye-principy/ (дата обращения: 10.12.2018).

22. Байтуганов В. И. Народная манера пения и обучение ей. URL: http://www.rnd-sale.ru/ (дата обращения: 10.12.2018).

23. Калугина Н. В. Основы методики работы с русским народным хором. URL: http://www.rndsale.ru/ (дата обращения: 10.12.2018).

24. Пивницкая О. В. Освоение школьниками национального песенного фольклора (на материале среднерусского региона): автореф. дис. ... канд. пед. наук. М., 2008. 22 с.

\section{Поступила 10.01.2019; принята к публикации 15.03.2019.}

\section{Об ав торе:}

Пивницкая Ольга Васильевна, старший преподаватель кафедры методологии и технологий педагогики музыкального образования ФГБОУ «Московский педагогический государственный университет» (МПГУ) (ул. Малая Пироговская, 1, стр. 1, Москва, Российская Федерация, 119991), кандидат педагогических наук, доцент, olgafolk@list.ru

Автором прочитан и одобрен окончательный вариант рукописи. 


\section{REFERENCES}

1. Nikolaeva E. V. Istoriya muzykal'nogo obrazovaniya. Drevnyaya Rus'[History of music education. Ancient Russia]. Moscow: Vlados Publ., 2003. 208 p. (in Russian).

2. Asaf'ev B. V. Muzykal'naya forma kak protsess [Musical form as a process]. Leningrad: Muzyka Publ., 1971. 376 p. (in Russian).

3. Medushevsky V. V. Intonatsionnaya forma muzyki: Issledovanie [Intonation form of music: Research]. Moscow: Kompozitor Publ., 1993. 265 p. (in Russian).

4. Zemtsovskyj I. I. Apologiya slukha [Apologia of the hearing]. Muzykal'naya akademiya [Musical Academy], 2002, no. 1, pp. 1-12 (in Russian).

5. Shamina L. V. Etnograficheskaya paradigma shkol'nogo muzykal'nogo obrazovaniya: ot "etnografii slukha" k muzyke mira [Ethnographic paradigm of school music education: from "Ethnography of hearing" to the music of the world]. Prepodavatel'. 2002, no. 6, pp. 21-27 (in Russian).

6. Bromlej K. V., Temerina N. S. Russkie narodnye pesni: sbornik dlya chteniya s lista $v$ kurse sol'fedzhio [Russian folk songs. Collection for reading from a sheet in the course of solfeggio]. Moscow: Muzyka Publ., 1972. 239 p. (in Russian).

7. Lobanov M. A. Etnosol'fedzhio na materiale traditsionnoj pesni russkoj derevni [Atmosophere material on the traditional songs of the Russian countryside]. St. Petersburg: Severnyj olen' Publ., 1996. 74 p. (in Russian).

8. Pivnitskaya O. V. Shkola fol'klornogo sol'fedzhirovaniya [School of folk collegiove]. Issue 1. Moscow: Kompozitor Publ., 2001. 92 p.; Issue 2. Moscow: Kompozitor Publ., 2002. 131 p. (in Russian).

9. Rudneva A. V. Russkoe narodnoe muzykal'noe tvorchestvo [Russian folk music]. Moscow: Kompozitor Publ., 1994. 224 p. (in Russian).

10. Shchurov V. M. O regional'nykh traditsiyakh v russkom narodnom muzykal'nom tvorchestve [On the regional traditions of Russian folk music]. Muzykal'naya fol'kloristika [Musical folklore study]. Issue 3. Moscow: Sovetskij kompozitor Publ., 1986, pp. 11-47 (in Russian).

11. Shamina L. V. Shkola russkogo narodnogo peniya [School of Russian folk singing]. Moscow: Moskovskij gosudarstvennyj fol'klornyj tsentr "Russkaya pesnya" WMO Publ., 1997. 88 p. (in Russian).

12. Lapin V. A. Russkij muzykal'nyj fol'klor $i$ istoriya [Russian musical folklore and history]. Moscow: Moskovskij gosudarstvennyj fol'klornyj tsentr "Russkaya pesnya" Publ. 1995. 200 p. (in Russian).

13. Asaf'ev B. V. Russkaya narodnaya pesnya i ee mesto v shkol'nom muzykal'nom vospitanii i obrazovanii [Russian folk song and its place in school musical education and education]. O khorovom iskusstve: cbornik statej [About choral art: Sat. articles]. Compilation and comments by A. Pavlov-Arbenin. Leningrad: Muzyka Publ., 1980, pp. 167-178 (in Russian).

14. Arkhangel'skie byliny $i$ istoricheskie pesni, sobrannye A. D. Grigor'evym v 1899-1901 gg.: s napevami, zapisannymi posredstvom fonografa [Arkhangelsk epics and historical songs collected by A. D. Grigoriev in 1899-1901: with melodies recorded by means of a phonograph]. In 3 volumes. Vol. 1. Part 1. Pomorze; Part 2. Pinega. Moscow: Imperator. akad. Publ., 1904. 705 p. (in Russian).

15. Hippius E. V., Ewald Z. V. Pesni Pinezh'ya [Songs of Pinega]. Moscow: Muzgiz Publ., 1937. 584 p. (in Russian).

16. Rudneva A. V. Narodnye pesni Moskovskoj oblasti [Folk songs of the Moscow region]. Moscow: Muzyka Publ. 1964. 115 p. (in Russian). 
17. Gilyarova N. N. Muzykal'nyj fol'klor Ryazanskoj oblasti. Ryazan' [Musical folklore of the Ryazan region]: Ryazanskij oblastnoj tsentr narodnogo tvorchestva Publ., 1994. 194 p. (in Russian).

18. Mekhnetsov A. M. Traditsiya kak osnovopolagayushchij printsip narodnoj muzykal'noj kul'tury [Tradition as a fundamental principle of the folk music culture]. Russkaya narodnaya pesnya. Stil', zhanr, traditsiya: sb. nauch. statej [Russian folk song. Style, genre, tradition: Sat. articles]. Editor and compiler A. M. Mekhnetsov. Leningrad: LOLGK named after N. A. Rimsky-Korsakov Publ., 1985, pp. 5-18 (in Russian).

19. Pushkina S. I. Russkie narodnye pesni Moskovskoj oblasti [Russian folk songs of the Moscow region]. Issue 2. Moscow: Sovetskij kompozitor Publ., 1988. 336 p. (in Russian).

20. Savel'eva N. M. O regional'nykh i lokal'nykh raznovidnostyakh tipovykh russkikh pesennykh struktur [On regional and local varieties of typical Russian song structures]. Problemy kompozitsii narodnoj pesni: nauch. trudy Moskovskoj gosudarstvennoj konservatorii [Problems of folk song composition. Scientific works of the Moscow state Conservatory]. Moscow, 1977, pp. 41-70 (in Russian).

21. Baklykova E. V. Narodnaya manera peniya. Osnovnye printsipy [Folk manner of singing. Basic principles]. Available at: http://www.rnd-sale.ru/baklykova-elena-narodnaya-manera-peniyaosnovnye-principy (in Russian).

22. Bajtuganov V. I. Narodnaya manera peniya i obuchenie ej [Folk manner of singing and teaching it]. Available at: http://www.rnd-sale.ru (in Russian).

23. Kalugina N. V. Osnovy metodiki raboty s russkim narodnym khorom [Fundamentals of methods of work with the Russian folk choir]. Available at: http://www.rnd-sale.ru (in Russian).

24. Pivnitskaya O. V. Osvoenie shkol'nikami natsional'nogo pesennogo fol'klora (na materiale srednerusskogo regiona) [Development of national song folklore by schoolchildren (by the material of the Central Russian region)]. Extended abstract of PhD dissertation (Pedagogy). Moscow, 2008. 22 p. (in Russian).

Submitted 10.01.2019; revised 15.03.2019.

About the author:

Olga V. Pivnitskaya, Senior Lecturer at the Department of Methodology and Technology of the Music Education, Moscow Pedagogical State University (MPGU) (Malaya Pirogovskaya Street, 1/1, Moscow, Russian Federation, 119991), PhD in Pedagogical Sciences, Associate Professor, olgafolk@list.ru

The author has read and approved the final manuscript. 


\section{РАЗВИТИЕ СОСРЕДОТОЧЕННОСТИ БУДУЩЕГО МУЗЫКАНТА-ПЕДАГОГА В КЛАССЕ СОЛЬНОГО МУЗЫКАЛЬНО- ИНСТРУМЕНТАЛЬНОГО ИСПОЛНИТЕЛЬСТВА}

\section{Е. П. Красовская,}

Московский педагогический государственный университет, Москва, Российская Федерация, 119991

Аннотация. B статье получают раскрытие базовые характеристики сосредоточенности как важнейшего свойства внилания будуших педагогов-лузыкантов и методы, способствующие её эбббективнолу фборлированию на ббортепианных занятиях. Изучение научных подходов к данному понятию в контексте фбизиологии, общей психологии, педагогики показало, что сосредоточенность выступает важнейшил психологическили условиел углублённого познания предлетов и явлений, оптилального протекания познавательной и практической деятельности человека, особенно в процессе учения и творчества. Повышению концентрации внимания способствует активность личности, её увлечённость деятельностью и неослабевающий интерес $к$ предлету сосредоточения. Успешность развития данного свойства внилания во многол зависит от приленения педагогол специальньх приёлов по организации деятельности с объектол, выделения в нёл новых аспектов, их анализа и сравнения, поиска новых свойств объекта, путей и возложностей его приленения или совершенствования. Специальное внилание уделяется характеристике основных кониептуальньх положений, обборлившихся в недрах педагогики музыкального образования для развития сосредоточенности обучаюшихся. Проведённый анализ позиций авторитетных представителей исполнительского искусства и педагогов-лузыкантов показал, что сосредоточенность является отправной точкой музыкально-исполнительского творчества, важньл условиел продуктивности пианистической работы. Обобщение опьтта выдающихся представителей фбортепианного исполнительства и театральной педагогики позволило предложить эбббективные подходы к развитию сосредоточенности как значилого качества, в нелалой степени влияющего на раскрытие творческого потенииала будущего музыканта-педагога и определяющего возложность его продуктивной салореализации в инструлентально-исполнительской деятельности. Автор приходит к выводу о тол, что способность концентрироваться поддаётся иеленаправленнолу и планолернолу развитию под руководствол педагога в ходе проведения занятий в классе, на репе- 
тиииях, а также в долашней работе при выполнении специально организованных упражнений. Настойчивость в овладении техникой сосредоточенности путёл выполнения специально организованных упражнений позволит музьканту сознательно управлять процессол внилания, существенно увеличить время концентрации на решении творческой задачи.

Ключевые слова: педагогика музыкального образования, музыкальноинструлентальное исполнительство, сосредоточенность как свойство внилания музыканта-педагога, класс фбортепиано.

Благодарности: Данная статья выполнена в контексте научной работьь кафбедры музыкально-исполнительского искусства Института изящных искусств Московского педагогического государственного университета.

Для цитирования: Красовская $E$. П. Развитие сосредоточенности будущего музыканта-педагога в классе сольного музыкально-инструментального исполнительства // Музыкальное искусство и образование. 2019. T. 7. № 1. С. 131-152.

\title{
DEVELOPMENT OF CONCENTRATION
}

FUTURE MUSICIAN-TEACHER IN THE CLASS

\section{OF SOLO MUSICAL AND INSTRUMENTAL PERFORMANCE}

\section{Elena P. Krasovskaya,}

\author{
Moscow Pedagogical State University (MSPU), \\ Moscow, Russian Federation, 119991
}

\begin{abstract}
The article examines the basic characteristics of concentration as most important property of attention of future teachers-musicians and the methods which help its effective formation during piano lessons. Studying of scientific approaches to this concept of a context of physiology, the general psychology, pedagogy showed that concentration acts as the most important psychological condition of deeper understanding of objects and the phenomena, optimum course of cognitive and practical activities of the person, especially in the course of the learning and creativity. A person activity, enthusiasm and continuing interest in a concentration subject help increase of attention concentration. The success of development of this property of attention in many respects depends on application by the teacher of special receptions for the organization of activity with an object, allocations in new aspects, their analysis and comparison, search for new properties of an object, ways and opportunities of its application or improvement. Special focus is placed on characteristics of the conceptual ideas of music pedagogy for development
\end{abstract}


of attention concentration of students. The carried-out analysis of positions of authoritative representatives of performing art and music pedagogy showed that concentration is a starting point of musical and performing creativity and an important condition of efficiency of pianist work. Summarize experience of outstanding representatives of piano performance and theatrical pedagogy allowed to suggest the effective approaches to development of concentration as the significant quality in no small measure influencing disclosure of creative potential of future musician-teacher and defining a possibility of his productive self-realization in an instrumental and performing activity. The author comes to a conclusion that the ability to concentrate can be developed under the leadership of the teacher during training in a class, on rehearsals and also in homework when performing specially organized exercises. The persistence in mastering the concentration equipment by performance of specially organized exercises will allow the musician to operate consciously process of attention, it is essential to increase concentration time on the solution of a creative task.

Keywords: music pedagogy, musical and instrumental performance, concentration as property of attention of the musician-teacher, piano class.

Acknowledgements: This article is performed in the context of scientific work of department of musical performing art of Institute of Fine Arts of the Moscow Pedagogical State University.

For citation: Krasovskaya E. P. Development of concentration future musician-teacher in the class of solo musical and instrumental performance // Muzykal'noe iskusstvo $i$ obrazovanie = Musical Art and Education, 2019, vol. 7, no. 1, pp. 132-152.

Сосредоточенность - вечная тайна всякого совершенства.

С. Цвейг [1].

\section{Введение}

В структуре вузовской подготовки музыкантов-педагогов одно из центральных мест занимает проблема формирования инструментальноисполнительского мастерства. Овладение им, как известно, требует не только мобилизации музыкальных способностей обучающихся, но и активного фрункционирования всего психического потенциала личности, включая эмоциональную сфреру, вос- приятие, мышление, воображение, волю, внимание и т. д.

Важнейшим фрактором достижения студентами высоких результатов в сфрере инструментального исполнительства (фортепиано) выступает сосредоточенность, под которой принято понимать концентрированность сознания индивида на одном и том же объекте при полном отключении от других [2, с. 491]. И. Гофмман называл её «первой буквой в алфавите успеха» и считал, что данное свойство не толь- 
ко выражает уровень профессионально значимых качеств музыканта, но и обеспечивает их всестороннее развитие [3, с. 96]. Рассматривая сосредоточенность как важнейший психологический фрундамент овладения пианистическим искусством, он призывал педагогов уделять её формированию самое пристальное внимание.

Между тем, анализ современной практики обучения студентов педагогических вузов в классе сольного музыкально-инструментального исполнительства (фортепиано) показывает, что целенаправленное развитие сосредоточенности зачастую остаётся на периферии учебно-образовательного процесса. Проведённое нами анкетирование преподавателей, ведущих занятия по названной дисциплине, позволило заключить, что указанная тенденция объясняется несколькими причинами.

Одна из них связана с сокращением часов, выделяемых в учебных планах подготовки бакалавров педагогического образования на исполнительские дисциплины, что дополнительно зачастую усугубляется заменой индивидуальной формы обучения мелкогрупповыми занятиями. Другая - обусловлена недостаточной разработанностью анализируемой проблемы в научной литературе, наличием представленных в ней лишь отдельных рекомендаций и методических приёмов развития данного свойства внимания обучающихся. Не последнюю роль, негативно влияющую на результаты работы педагога по развитию сосредоточенности студентов, играет, по мнению респондентов, и понижение общего уровня сформированности внимания у современной молодёжи, рост числен- ности молодых людей, для которых характерно так называемое "клиповое мышление» [4].

Перечисленные причины порождают скептическое отношение многих преподавателей к целесообразности систематической работы по воспитанию сосредоточенности студентов на фортепианных занятиях, что негативно сказывается на процессе освоения ими музыкальных произведений, приводят к фррагментарности интерпретации и нарушению логики становления образа, ухудшают результаты сценических выступлений и т. д.

В этих условиях актуальной задачей педагогики музыкального образования является поиск эбббективных подходов к развитию сосредоточенности как значимого качества, в немалой степени влияющего на раскрытие творческого потенциала будущего музыканта-педагога и определяющего возможность его продуктивной самореализации в различных видах профрессиональной деятельности. Рассмотрение круга вопросов, имеющих существенное значение для успешного формирования сосредоточенности обучающихся, представляется целесообразным начать с анализа научных подходов к данному понятию, и. прежде всего, с его определения.

\section{Сосредоточенность как свойство внимания и особенности её рассмотрения в физиологии, общей психологии и общей педагогике}

Термин «сосредоточенность» происходит от глагола «сосредоточить», означающего «соединить в одном месте, направить, напрячь, устремляя на что-нибудь одно» [5, с. 750]. Указы- 
вая на этимологическую связь данного термина со славянским средоточие, а также немецким Mittelpunkt, В. В. Виноградов относит его появление к середине XVIII века для пере-

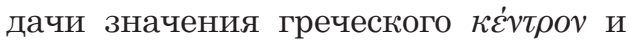
латинского centrum как «точки, воображаемой в середине круга или шара», «центра», "средоточия земли» [6, с. 463]. В восточной фрилософрии сосредоточенностью - саньлэй - обозначается психическое состояние, в котором сознание целиком сконцентрировано на едином фокусе («одной точке») и не подвержено хаосу. Являясь одним из важнейших методов буддийской практики психической саморегуляции, сосредоточенность направлена на стабилизацию и упорядоченность, служит достижению уравновешенности, спокойствия и умиротворённости [7]. В сходной трактовке данный термин вошёл в научный обиход, получив фрундаментальную разработку в области фризиологии, психологии, педагогики и др.

В контексте анализируемой проблемы интересными представляются размышления В. М. Бехтерева о важности «культуры сосредоточения» для достижения человеком максимальной продуктивности в интеллектуальной деятельности, его указания на сушествование непосредственной зависилости между работой сознания и способностью $\kappa$ сосредоточению. Согласно его теории, процесс, обозначенный как «сосредоточение на предмете задачи», находится в «центре осуществления всякого вообще умственного труда» [8, с. 97].

Большое значение для выяснения фбизиологических леханизлов сосредоточенности имеют работы выдающихся русских учёных-фризиоло- гов. Так, в исследованиях И. П. Павлова о безусловных ориентировочных редрлексах фризиологическое объяснение феномена сосредоточенности (как свойства второй сигнальной системы) связано с появлением в коре головного мозга очага сильного возбуждения и индуцированного им тормозного поля, что порождает глубокий, действенный интерес человека к какомулибо событию, факту или деятельности. В повседневной жизни приходится наблюдать различные уровни сосредоточенности. При поверхностной сосредоточенности сознания человек может при слуховом восприятии той или иной информации не слышать её содержания. Глубокая (вплоть до одержимости) поглощённость объектом, характеризующаяся «безотступным думанием» о нём, является, по мнению И. П. Павлова, необходимым условием крупных достижений и показателем интеллектуальной одарённости человека в различных областях деятельности [9, с. 1134]. Эти выводы подтверждаются многочисленными фрактами из области науки и искусства. В истории музыки в рассматриваемом контексте уместно вспомнить примеры, свидетельствующие о глубочайшей сосредоточенности В. А. Моцарта, П. И. Чайковского, Д. Д. Шостаковича, С. Т. Рихтера.

Не менее важными для развития сосредоточенности на фортепианных занятиях являются и основные положения теории доминанты А. А. Ухтомского. Рассматривая доминанту как главный принцип работы нервных центров и организации поведения индивида, исследователь считал, что в мозгу человека всегда имеется такой очаг возбуждения, который привлекает к себе иные поступающие 
в мозг сигналы. Благодаря этому, данный очаг начинает всё больше главенствовать (доминировать) над другими, становясь устойчивым очагом возбуждения. На основе доминанты возникает углублённое и устойчивое сосредоточение, благодаря которому субъект получает возможность отвлечься от посторонних раздражителей, мешающих работе [10]. Раскрывая нервный механизм длительной интенсивной сосредоточенности человека на том или ином объекте, теория Ухтомского вышла за рамки фозиологии и успешно применяется в различных науках. Можно предположить, что со временем данный метод найдёт применение и в процессе обучения игре на фортепиано в вузе. Его возможности, на наш взгляд, могут способствовать активизации работы ассоциативной сферы, воображения и франтазии будущих музыкантов-педагогов, повышению продуктивности исполнительского анализа изучаемых произведений.

Углублённые данные о сосредоточенности содержатся в научных трудах отечественных психологов - Л. С. Выготского, С. Л. Рубинштейна и др. [11]. При характеристике сосредоточенности как важнейшего свойства внилания, позволяющего индивиду быть полностью поглощённым каким-либо делом или объектом, подчёркивается его значимость для оптимального протекания познавательной и практической деятельности человека.

В качестве синонима анализируемого понятия в научных публикациях используется термин «концентрация» внимания, которым принято обозначать степень или интенсивность сосредоточенности, тот фокус, в котором собрана психическая или сознательная деятельность субъекта в данный момент [12]. Показателем интенсивности является невозможность переключить внимание с определённого предмета или вида деятельности при помощи отвлекающих фракторов. Концентрированное внимание рассматривается также как внимание интенсивной сосредоточенности на одном или небольшом числе объектов. В этом контексте содержание термина определяется единством двух признаков - интенсивности и узости внимания [Там же].

В сфрере педагогики, существенное значение воспитанию и развитию сосредоточенности уделял К. Д. Ушинский, отмечая, что способность к сосредоточению в той или иной сфрере деятельности развивается не только путём мобилизации сознания, но и предполагает активную работу всей души. Именно с фоннкционированием сосредоточенности внимания К. Д. Ушинский связывал осознанность и продуктивность познавательной деятельности человека. В этой связи исследователем подчёркивалось значение интереса как важнейшего стимулирующего фрактора сосредоточения [13].

Проведённый нами краткий анализ понятия «сосредоточенности» показывает, что она выступает важнейшим психологическим условием углублённого познания предметов и явлений, оптимального протекания познавательной и практической деятельности человека, особенно в процессе учения и творчества. Повышению концентрации внимания способствует активность личности, её увлечённость деятельностью и неослабевающий интерес к предмету сосредоточения. Успешность развития данного свойства внимания во многом зависит от отбора и примене- 
ния специальных приёмов педагогом по организации деятельности c объектол, а именно: «выделения в нём новых аспектов, их анализа и сравнения, поиск новых свойств объекта, путей и возможностей его применения или совершенствования» [14, с. 186]. Обозначив базовые характеристики сосредоточенности, перейдём к рассмотрению данного свойства внимания в контексте музыкальной психологии и психологии музыкального образования.

\section{Проблема сосредоточенности в музыкальной психологии и психологии музыкального образования}

Одним из первых к анализу сосредоточенности обратился Б. М. Теплов. Данному свойству внимания учёный отводил огромную роль «в развитии всех способностей человека», включая музыкальные [15, c. 24]. Изучение структуры музыкальной одарённости (в частности, проблемы слуховых представлений и слухового воображения как результатов углубления в творческий процесс и высокого сосредоточения на предмете деятельности) позволило Теплову прийти к важному выводу о теснейшей связи психологической природы творческого вдохновения с проблемой сосредоточенности внимания [Там же, с. 30]. Труды учёного дали импульс к рассмотрению данного свойства сквозь призму важнейших психологических проблем профессионально-творческой деятельности и личностного мира музыканта.

Так, М. С. Старчеус рассматривает способность концентрировать слуховое внимание как вторую (наряду с тонкостью слуха) важнейшую осно- ву профессионального слуха музыканта. С точки зрения автора, сосредоточенность на исполняемом произведении представляет собой napaдоксальное явление: "С одной стороны, исполнение требует контроля внутренних представлений, организующих действия исполнителя, а с другой - предельного внимания к реальному звучанию. Гармонично совместить два полярно направленных (в каком-то смысле взаимоисключающих) вектора внимания очень трудно, но необходимо» [16, c. 241]. Для выработки индивидуальной техники концентрации внимания автор советует определить оптимальный темп работы, а также её необходимый и достаточный объём, что предостережёт музыканта от отвлекаемости и перенапряжения внимания. При диагностике сосредоточенности педагогам рекомендуется помнить о том, что формирование различных свойств внимания зависит от трёх относительно самостоятельных факторов: индивидуальных особенностей высшей нервной деятельности, обучения навыкам организации внимания и индивидуальных мотивов, потребностей, интересов и целей человека [Там же, с. 243].

Существенная роль в формировании сосредоточенности музыканта, по мнению Г. М. Цыпина, принадлежит генетическил ббакторал, окружающей среде, а также элоиионально-волевыл качествал личноcmu, позволяющим успешно преодолевать возникающие при работе над произведением трудности [17, с. 227]. В процессе музыкально-исполнительской деятельности воля выражается в систематических занятиях на инструменте, в постоянном стремле- 
нии повысить свой уровень исполнительского мастерства - то есть проявляется в концентрированном внимании и личной сосредоточенности на решении технических и исполнительских задач.

Концентрированность внимания обеспечивает успешность и продуктивность деятельности. В связи с этим одним из важнейших условий развития сосредоточенности Г. М. Цыпин называет качество методики преподавания: умение педагога формировать сосредоточенность как учебную и творческую способность. «Если учащийся обучен рациональным приёмам учебной деятельности, умеет ставить перед собой определённые задачи, добиваться их решения; ... ему проще обрести нужный тонус в работе, настроить себя на неё, внутренне собраться, мобилизоваться, сосредоточиться и т. д. Наконец, если у этого учащегося сорормирована привычка к регулярным, каждодневным занятиям, то входить в нужное психологическое состояние ему будет проще - и, наоборот» [Там же, с. 228].

Сказанным определяется необходимость обратиться к анализу методов и приёмов работы, оформившихся в недрах педагогики музыкального образования для развития данного свойства внимания обучающихся.

\section{Основные подходы к развитию сосредоточенности в педагогике музыкального образования}

Анализ научно-методической литературы показывает, что развитие сосредоточенности как качества исполнительского внимания вплоть до конца XIX столетия не входило в реестр обязательных задач инструмен- тального обучения. В фортепианной педагогике учащимся в ходе домашнего музицирования, направленного, в основном, на решение виртуозно-технических задач, нередко разрешалось читать художественную литературу, «чтобы “не соскучиться” при монотонных многочасовых экзерсисах» [18, с. 32].

Вместе с тем на рубеже XVIIIXIX веков отдельные исполнители и педагоги, «опережавшие время», всерьёз задумывались о роли сосредоточенности в деятельности музыканта. Сторонниками содержательных, внутренне организованных занятий учащихся, отмеченных устойчивой и целенаправленной работой анализируемого качества, выступали Ф. Шопен [19], Р. Шуман [20], Ф. Лист [21] и др. Предостерегая учеников от притупления внимания и слуха, они связывали успешность пианистического развития своих воспитанников не с изнурительными занятиями по освоению технологических трудностей, а с культивированием состояния предельной сосредоточенности.

Особая заслуга в формировании представлений о сосредоточенности как профессионально-значимом качестве учащегося-пианиста принадлежит братьям А. Г. и Н. Г. Рубинштейнам. В классе Антона Григорьевича Рубинштейна методы развития рассматриваемого свойства внимания подбирались для ученика с учётом его индивидуальных особенностей и были направлены на решение всевозможных художественных, артикуляционных, динамических, ритмических и колористических задач. Доказательством тому служат его рекомендации по освоению простого 
технического задания, связанного c исполнением четырёх позиционных фригур мажорного трезвучия (пример 1).

Основатель Петербургской консерватории предлагал учащимся разучить их в различных тональностях, применяя следующие способы:

1. Играть legato, non legato, portamento, staccato, staccatissimo, сочетая артикуляционные варианты с изменениями темпа (от очень медленного до быстрого с последующим возвращением в медленный) и звучности.

2. Упражняться таким образом, чтобы вариантные задания для каждой из рук не совпадали (например, правая рука - pp, legato и leggiero, левая - $m f$, staccato и portamento).

3. Расчленить техническую группу лигами (по два или четыре звука), при этом использовать варианты, при которых лиги в руках не совпадают.

4. Учить позиционные формулы в разнообразных вариантах с педалью [22, с. $179-180]$.

По мнению Н. Г. Рубинштейна, такая работа в корне меняла представления студентов о пианистическом труде, превращала его из неосознанного механического упражнения в умственную психическую деятельность, требующую от ученика предельной концентрации внимания, активизации аналитических способностей и проявления волевых качеств, направленных на решение музыкальной задачи [23].

В дальнейшем принципы занятий, построенных на основе умственной сосредоточенности, были чётко сорормулированы В. И. Сафоновым в предисловии к разработанным им упражнениям. Автор предостерегает обучающихся от механической игры, «ибо упражнения эти суть не только упражнения пальцев, но и одновременно упражнения мозга. Это своего рода телеграфр между мозгом и концами пальцев, требующий от играющего полного сосредоточения» [24, c. 3]. Данное высказывание свидетельствует о том, что всякое упражнение, применяемое для совершенствования техники пианиста, представляет собой, по мнению Сафонова, результат работы центральной нервной системы и должно рассматриваться как психофизический процесс. От яркости представления о цели, от умения ученика сосредоточить внимание и направить свою энергию на её достижение зависит в огромной степени высокое качество выполнения поставленной задачи.

$\mathrm{B}$ первой половине $\mathrm{XX}$ столетия ценный вклад в формирование «культуры сосредоточенности» внесли представители западноевропейской школы пианизма К. Леймер и В. Гизекинг. Суть предлагаемой ими методики заключалась в формировании в сознании учащихся ясного внутреннеслухового представления о произведении на начальном этапе разучивания (в частности, мысленной проработки музыкального материала без непосредственной опоры на реальное звучание инструмента). Развитие навыка критического вслушивания и постоянного самоконтроля путём специальной тренировки памяти посредством

Пример 1

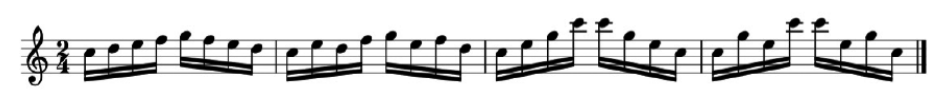


анализа нотного текста, осуществлялось на основе воспитания предельной сосредоточенности внимания учащихся, поддерживаемой в течение строго фиксированного времени - 2030 минут. Такое ограничение Леймер обосновывал следующим образом: «Умственный труд, которого я требую, конечно, означает большое напряжение и очень не нравится ленивым мыслью. Но только став на такой путь, можно достигнуть высоких, даже поразительных результатов» [25, с. 33].

Подобный подход к формированию сосредоточенности лежит в основе концепции «звукотворческой воли» К. А. Мартинсена [26] и спещиальной техники умственной сосредоточенности с целью достижения «совершенно ясной звуковой картины» И. Гофммана [3, с. 30]. Данные техники позволяли выучивать музыкальные произведения «в уме», «не прибегая вовсе к помощи пальцев» [Там же].

В отечественной педагогике музыкального образования публикации с подобной тематикой вышли в свет в середине XX столетия. В них сосредоточение рассматривалось как средство воспитания слуха, необходимое психологическое условие развития правильных пианистических движений (техники), эффрективный приём преодоления негативных последствий эстрадного волнения и развития сольно-концертных навыков $[27 ; 28 ; 29 ; 30 ; 31]$.

В контексте рассматриваемой проблемы интересными представляются размышления Н. К. Метнера, изучавшего механизмы сознательной саморегулящии психических состояний, и считавшего работу «в фокусе» сосредоточенности внимания одним из важнейших фракторов интенсивности по- вседневных занятий музыканта [27, c. 6]. Для достижения наибольшей концентрированности сознания на осваиваемом произведении Николай Карлович рекомендовал молодым пианистам как можно больше упражняться с закрытыми глазами, как бы «вытягивая слухом» желаемую звучность [Там же, с. 5]. Другим эффрективным методом повышения сосредоточенности являлось изучение музыкального материала без инструмента, то есть путём активизации внутреннеслуховых представлений. Метнер был убеждён, что подобная исполнительская медитация не только позволяет отвлечься от посторонних раздражителей и сосредоточенно погрузиться слухом в контролирование логики развёртывания музыкального потока, но и способствует осуществлению выбора необходимых исполнительских (игровых) движений для её воплощения [Там же].

Ценные размышления о сосредоточенности содержатся в методическом исследовании А. П. Щапова [28], рассматривавшего данное свойство внимания с позиций антиципации (т. е. сосредоточенности слуховой сореры на предстоящих музыкальных событиях) и ретроспекции (т. е. её направленности на восприятие и оценку уже исполненного музыкального материала). В этой связи автор выделяет два вида сосредоточенности: локальную («узкую»), обусловленную восприятием текущей интонации, её связями с предыдущей и последующей, и «широкую», связанную с восприятием целостной структуры музыкального произведения. Научить концентрировать и распределять внимание «между игровой перспекцией и игровой ре- 
троспекцией - одна из трудных задач воспитания исполнителя», заключает А. П. Щапов [Там же, с. 12]. Такая концентрация достигается путём постановки перед обучающимся значительного числа целей, доступных и часто меняющихся, и кроме того - максимально связанных с художественной сущностью произведения. В контексте рассматриваемой проблемы важным представляется и анализ исследователем такого вопроса, как сохранение концентрации внимания аудитории на протяжении всего выступления музыканта-исполнителя. Ослабление внимания слушателей автор связывает со снижением сосредоточенности внимания интерпретатора и уменьшением его артистического самоконтроля.

Вопросы сосредоточенности (концентрации) как качества исполнительского внимания конкретизируются и получают дальнейшую детальную разработку в фондаментальной монографии Г. П. Прокофьева [29]. В планомерном формировании сосредоточенности автор видит не только эфорективное средство развития самых разнообразных исполнительских качеств, но также предпосылку успешного воспитания и обучения пианиста в целом [Там же, c. 423]. Методист предлагает организовать процесс формирования данного качества путём специальной целенаправленной педагогической деятельности, что предусматривает «своего рода структуризацию процесса воспроизведения музыки». Он рекомендует осуществлять процесс воспитания концентрации внимания учащегося поэтапно: вначале - путём сосредоточения на различных элементах исполнительского процес- са (звучании музыкальной ткани, игровых действиях), а затем стремиться к тому, чтобы ученик мог «воспринимать реальный результат собственной исполнительской деятельности в самом процессе действования» [Там же, с. 425]. Существенное средство развития сосредоточенности внимания Г. П. Прокофьев усматривает также в формировании эмоциональной отзывчивости на музыку в процессе фортепианных занятий, а также в стимулировании интереса учащихся к изучаемым произведениям, своей исполнительской деятельности.

О важности интереса в формировании длительного сосредоточения пишет представитель ленинградской фортепианной школы С. И. Савшинский. Самарий Ильич считает, что более или менее продолжительной концентрации внимания при отсутствии непосредственной заинтересованности пианиста изучаемым материалом невозможно достичь ни по приказу учителя, ни по самоприказу. Если пианистические занятия осуществляются учащимся без заинтересованности, дисциплины и умения, они быстро приводят к рассеянности - оборотной стороне сосредоточенности [30, с. 178]. Формированию исполнительской сосредоточенности будет способствовать выработка «умения даже на самом простом материале, непрерывно ставить перед собой задачи, ... оглядывать и ослушивать изучаемое с разных сторон, искать и находить в нём новое и сопоставлять его со старым» [Там же, с. 179]. По мнению Савшинского, проблема формирования сосредоточенности стоит не столь остро в работе с одарёнными детьми. Если учащийся-пианист ода- 
рён артистически, то ему изначально свойственно сосредотачиваться на исполнительском процессе, ибо способность целиком погружаться в своё дело - характерное свойство таланта» [Там же, с. 228].

Существенный вклад в развитие проблемы сосредоточенности внёс Г. М. Коган, который подробно анализирует это важнейшее профессиональное качество пианиста, рассматривая его в 3 аспектах: распределения внилания, режила занятий пианиста и эстрадного волнения. Считая сосредоточенность «близкой родственницей» целеустремлённости, вторым («после ориентации сознания на цель») условием успешного осуществления пианистической деятельности, педагог видит в ней отправную точку формирования распределённости внимания - важнейшего качества пианиста. В процессе исполнения музыкант вынужден следить одновременно за точностью исполнения, общим художественным образом и свободой своих движений. Его внимание распределяется одновременно как бы в двух направлениях: по горизонтали и по вертикали. Горизонтальное внимание исполнителя сосредоточено на непосредственном моменте исполнения, фррагменте, следующим после него и одновременно охватывает единый образ произведения. Вертикальный пласт внимания охватывает координацию рук, фрактуру, голосоведение. Путь к такому распределению внимания и лежит через воспитание культуры сосредоточения. Чтобы научиться видеть многое, нужно вначале научиться качественно и чётко видеть одно. Чтобы успешно выполнять одновременно несколько видов работы, необходимо одной из них владеть так, чтобы она выполнялась в значительной мере автоматически, как бы «сама собой». Автоматизация деталей позволяет разгрузить сознание от технических подробностей для того, чтобы сосредоточить его на интерпретации целого.

Рассматривая проблему сосредоточенности в контексте режима занятий пианиста, Коган пишет о пользе лишь тех часов, при которых работа совершается с полной концентрацией внимания. Часы, посвящённые упражнениям, выполненным в состоянии "полусосредоточенности», то есть при скользящем рассеянном внимании учащегося-пианиста, оказываются простой потерей времени. Посторонние мысли порождают лишние движения, приводя, тем самым, к неполноценности пианистических результатов, малой эффективности занятий. Говоря о количественной стороне сосредоточенности, Коган советует заниматься сосредоточенно столько, сколько это возможно. Продолжение занятий после достижения «предела длительности внимания» физически возможно, но бесполезно и даже вредно. Занятия до боли в спине (руках или пальцах) - признак не столько трудоспособности и прилежания, сколько мозговой лени: если голова не устала раньше, значит, пианист и не начинал заниматься по-настоящему [31].

Говоря о проблеме сосредоточенности внимания в контексте сценического волнения, Г. М. Коган рекомендует применять в процессе фортепианных занятий методы, почерпнутые из системы К. С. Станиславского [32]. Овладение ими, по его мнению, помогает концентрировать внимание на 
объекте деятельности - музыкальном произведении, т. е. быть всецело погружённым в характер и содержание исполняемой музыки.

Учитывая значимость применяемых Станиславским методов, рассмотрим их подробнее. Выдающийся театральный режиссёр считал сосредоточенность активным познавательным процессом, обладающим эмоциональным и волевым основанием. Он полагал, что сосредоточенность актёра может тренироваться и без специальных упражнений, если только в своей повседневной работе артист предельно собран и дисциплинирован, сознательно и ответственно относится к своему профрессиональному делу. В противном же случае к формированию сосредоточенности необходимо идти путём целенаправленного волевого усилия.

Волевое сосредоточение, по Станиславскому, представляет собой результат серьёзной умственной работы творческого человека. Первым шагом на пути к его освоению должно стать ознакомление с тремя кругами (сферами) сосредоточения: малым, средним и большим. Малый круг ограничивается внутренним «Я» актёра, средний - помимо внутреннего «Я» включает также сцену. И, наконец, большой круг вбирает в себя дополнительно к названным объектам зрительный зал [Там же, c. 118-119]. Станиславский считал, что профессионализм актёра во многом определяется владением рассмотренными выше «кругами сосредоточенности» (или «передвижными кругами внимания» [Там же, с. 123]) особой техникой, помогающей «вцепляться в объект таким образом, чтобы затем уже сам объект, находя- щийся на сцене, отвлекал нас от того, что вне её» [Там же, с. 110].

Позиции Станиславского о тесной взаимосвязи сосредоточенности и волевых качеств пианиста разделяли Г. Г. Нейгауз [33], В. В. Софрроницкий [34] и Г. Р. Гинзбург [35].

Так, Нейгауз считал, что волевое усилие требуется музыканту даже для организации сосредоточения при выполнении несложной технической задачи. Концентрация же на глубине содержания художественного образа в целом предполагает значительные волевые проявления личности. На страницах книги «Об искусстве фортепианной игры» Генрих Густавович рассказывает о неожиданных результатах собственной сосредоточенности внимания, полученных в процессе работы над сонатой Бетховена ор. 106 B-dur Hammerklavier. Огромное волевое напряжение, желание, страсть, целеустремленность в достижении цели позволили ему выучить столь масштабное произведение всего за шесть (!) дней [33].

По убеждению В. В. Софрроницкого, воля, как особое свойство психики человека является специфической составляющей в структуре художественно-творческих способностей. Именно её закалка помогает музыканту сосредоточиться и успешно осуществлять исполнительский процесс творческого воссоздания музыкального содержания [34, с. 106].

Г. Р. Гинзбург был уверен, что проявление взаимозависимости сосредоточенности внимания и волевых качеств пианиста в равной степени относится к повседневной работе исполнителя, и к ситуации концертного или конкурсного выступления. Чтобы не поддаться сценическому 
волнению, не «сдаться» перед сложной аудиторией исполнителю нужна именно воля, позволяющая творчески сосредоточиться на исполняемом материале [35, с. 66].

Обобщающее представление о проблеме даёт исследователь М. В. Жижина. При помощи целенаправленной исполнительской воли, которая включает через контролирующую деятельность внимания все психические процессы - мышление, память, воображение, осуществляется перевод программы умственных представлений, содержащихся в сознании, в технический аппарат музыканта. Волевое сосредоточение внимания позволяет исполнителю вынести во внешний план (т. е. материализовать в реальном звучании) результаты предварительной работы, проделанной во внутреннеслуховой сфрере [36].

Проведённый анализ позиций авторитетных представителей исполнительского искусства и педагогики музыкального образования показал, что сосредоточенность является отправной точкой музыкально-исполнительского творчества, важным условием продуктивности пианистической работы. Творчество есть высшая форма сосредоточенности всей духовной и физической природы человека, которая полностью захватывает тело, ум, волю, чувство и воображение. Таким образом, становится очевидным, что формированию и развитию данного свойства внимания должно отводиться особое место в процессе музыкально-инструментального обучения будущих музыкантов-педагогов.

К числу первоочередных качеств внимания, необходимого для формирования исполнительского мастерства, относятся:
- быстрота сосредоточения (время, необходимое для «включения» в работу, психологический настрой на начало исполнения);

- устойчивость и динамика внимания в течение всего времени занятия;

- игнорирование различных помех и внешних немузыкальных дракторов;

- способность управления вниманием и использование его произвольной регуляции;

- концентрация внимания при изучении нового произведения, при исполнении сложных в техническом отношении фррагментов произведения (пассажей, каденций и т. д.).

При этом есть основание выделить исторически сложившиеся леетоды и приёль развития сосредоточенности:

1. Исполнение музыкального материала в заледленнол телпе с установкой на предсльшание («разведку слухом») последующего развёртывания музыки.

2. Кропотливая работа в медленном телпе над деталями произведения (концентрация внимания на изучении всех средств музыкальной выразительности: мелодии, гармонии, метроритма, динамических оттенков, особенностей тембра, фрактуры). Расчленение музыкальной ткани на отдельные фрагменты и их диффреренцированный анализ позволят сузить круг внимания, сконцентрировать его фокус на меньшем «поле» и, тем самым, ярче его осветить.

3. Исполнительская медитация, основанная на активизации работь внутреннего слуха. Отстранение от реальных игровых проблем (пальцевых 
автоматизмов) способствует сосредоточенности на прояснении логики развёртывания звуковой формы произведения, концентрации на эмоциональной и динамической весомости каждого фррагмента, выявлению качества и меры всех выразительных средств.

4. Овладение технологическими трудностяли произведения вне опоры на реальное звучание инструлента (беззвучная игра на клавиатуре). Указанный приём возможен в двух вариантах:

- «оттачивание» технически сложного фррагмента на закрытой крышке фрортепиано, путём опоры исключительно на внутреннее слышание музыкальной ткани;

- беззвучное проучивание музыкального материала путём лёгкого касания клавиатуры активными кончиками пальцев таким образом, чтобы было слышно только их прикосновение к клавишам, но не звучание инструмента. Напряжённая концентрация слухового внимания на воображаемом звучании фортепиано.

5. Применение в учебнол процессе специально разработанного "дидактического паспорта" произведения, содержащего анализ следующих позиций изучаемой музыки:

- основных этапов творчества композитора;

- исторической эпохи, к которой относится данное сочинение;

- фрилософрско-эстетических течений, господствовавших в эпоху создания произведения;

- особенностей национальных музыкальных традиций, музыкального быта исторического периода жизни и творчества композитора;

- наиболее известных творений архитектуры, живописи, скульпту- ры, литературы, относящихся к периоду творчества композитора;

- жанра произведения;

- архивных материалов, раскрывающих историю создания музыкального сочинения;

- встречающихся в произведении ремарок, включая эпиграфы, предисловия, иллюстрации;

- сведений, связанных с посвящением произведения какому-либо событию или конкретному лицу.

Поиск внетекстовой информации концентрирует внимание на конкретном предмете, способствует открытию в произведении новых граней.

6. Использование в процессе освоения музыкального содержания ассоииативных образных параллелей из области театрального искусства. Данный способ предполагает закрепление на занятиях с учениками фррагментов изучаемого музыкального материала за различными «персонажами» с помощью специальных обозначений в нотном тексте (главную партию исполняет один актёр, побочную - другой и т. д.), формирование преставлений о «ролевой» структуре музыкального произведения, аргументацию выбранных приёмов её динамизации. Тем самым он способствует концентрации внимания студентов на действиях каждого конкретного музыкального персонажа и выработке режиссёрского взгляда на развитие содержания музыкального сюжета. Благодаря ему происходит овладение обучающимися большим кругом сосредоточенности внимания, что позволяет возвыситься над музыкальными событиями, увидеть образ в гармоничной завершённости, постичь его в единстве авторского замысла. 
7. Стилулирование педагогол элоционального тонуса обучающегося путёл:

- «заражения» собственным увлечённым отношением к изучаемому материалу (воодушевлённым пропеванием, дирижированием и т. п.).

- активного взаимодействия с учащимся, требующего от него постоянного анализа своих действий.

8. Использование вербального эквивалента музыкальной интонации в виде подтекстовки - дополнительного манка активизации сосредоточенности. Такой приём направлен на осознание и прояснение выразительности мотива, его ритмического и динамического облика.

9. Создание особой атлосфберь при разучивании и исполнении лирических произведений. Имеется в виду работа над ними при выключенном свете (приглушённом освещении) или с закрытыми глазами. Такой методический приём формирует важнейшее качество - слуховую сосредоточенность (по Метнеру, слухом как бы «вытягивать» из инструмента «желаемую звучность), позволяющую пианисту полностью погрузиться в музыкальное содержание, внутренне сконцентрироваться на развёртывании музыкального потока.

10. Обеспечение контроля за исполнениел пауз и ферлат. Педагогическая целесообразность этого приёма объясняется тем, что во время исполнения пауз и фермат, зачастую не являющихся для учащихся важнейшим элементом музыкального содержания, теряется концентрация ими слухового внимания, что резко отрицательно сказывается на логике развёртывания художественной идеи. Во избежание этого необ- ходимо научить обучающегося творчески обращаться с тишиной, с помощью сосредоточенного внимания «услышать» паузу, «превратить беззвучие в музыку»: преодолеть в паузах образование смыслового вакуума, снижение эмоционального тонуса, способных нарушить логику становления художественного образа. Полезно во время пауз внутренне прослушать некий «мотив - эхо» или мысленно продирижировать.

11. Использование приёлов кониентрации внимания, почерпнутых из театральной педагогики К. С. Станиславского. Среди них:

a) специальные упражнения, имитирующие концентрацию внимания на каком-либо предмете или объекте при помощи:

- воспроизведения двигательной «маски сосредоточения», позволяющей как будто всматриваться вдаль, наблюдать, пристально следить за чем-либо;

- привлечения в процесс работы над музыкальным образом различных внемузыкальных ассоциаций, обостряющих чуткость слуха (слуховое представление воображаемых звуков морского прибоя, шелеста листьев и т. д.). Когда подобный внешний приём мобилизует сосредоточенность ученика, педагогу следует направить его слуховое внимание на конкретную «звучащую цель».

б) контроль фризической собранности, направленный на сохранение в процессе занятий концентрации внимания. подтянутости, особого эмоционального накала, стремления к точности движений. Небрежная посадка, сгорбленная спина, аморфный, вялый мышечный тонус - верные признаки отсутствия 
концентрации внимания ученика, слабого интереса к занятиям.

в) повторение наизусть (проговаривание) в строгом соответствии с текстом встречающихся в произведении авторских ремарок, темповых и динамических указаний, нюансировки и т. д.

Наряду с перечисленными методами, способами и приёмами необходимо также руководствоваться объективньлии педагогическили условиями сосредоточенности внилания:

1. Приучать работать в разных условиях, способствующих отвлечению от исполнения музыкального произведения.

2. Моделировать индивидуальные маршруты сосредоточенности внимания, тренировать способность быстро отделять главное от второстепенного в изучаемом материале.

3. Разработать совместно с учеником памятку приёмов сосредоточенной работы, которую следует использовать в процессе освоения музыкального содержания.

\section{Заключение}

Формирование способности концентрироваться поддаётся целенаправленному и планомерному развитию, совершенствуясь под руководством педагога в ходе проведения занятий в классе, на репетициях, в домашней работе при выполнении специально организованных упражнений. Настойчивость в овладении техникой сосредоточенности путём выполнения специально организованных упражнений позволит музыканту сознательно управлять процессом внимания, существенно увеличить время концентрации на решении творческой задачи.

В распоряжении педагога по классу сольного музыкально-инструментального исполнительства (фортепиано) имеется большое количество разнообразных методов, способов, приёмов, предназначенных для развития сосредоточенности внимания студентов. Их отбор, исходя из индивидуальных особенностей учащихся и конкретных условий реализации образовательного процесса, является одной из важнейших задач преподавателя. При этом важно понимать, что воспитание сосредоточенности внимания даст положительные результаты только в том случае, когда одновременно с целенаправленным действием педагога будет активно осуществляться процесс самовоспитания, подразумевающий соответствующие усилия по развитию собственного внимания со стороны обучающихся.

\section{БИБЛИОГРАФИЯ}

1. Ц Цвейг C. «Мендель-букинист». URL: http://lib.ru/INPROZ/CWEJG/mendel.txt (дата обращения 02.01.2019).

2. Словарь практического психолога / сост. С. Ю. Головин. Минск: Харвест; 1998. 551 с.

3. Гофман И. Фортепианная игра: Ответы на вопросы о фортепианной игре. М.: КлассикаXXI, 1998. $173 \mathrm{c}$.

4. Семеновских T. В. Феномен «клипового мышления» в образовательной вузовской среде // Интернет-журнал Науковедение, 2014. № 5 (24). URL: https://elibrary.ru/item.asp?id=23039503 (дата обращения 05.01.2019). 
5. Ожегов С. И., Шведова Н. Ю. Толковый словарь русского языка: 80000 слов и фразеологических выражений / Российская академия наук. Институт русского языка им. В. В. Виноградова. 4-е изд., дополненное. М.: Азбуковник, 1998. 944 с.

6. Виноградов В. В. История слов. URL: https://eknigi.org/gumanitarnye_nauki/185503-istoriyaslov.html (дата обращения 29.12.2018).

7. Титаренко М. Л. Китайская философия. Энциклопедический словарь. М.: Мысль, 1994. $652 \mathrm{c}$.

8. Бехтерев В. М. Рефлексология труда; под общ. ред. и с предисл. А. А. Пресса. Москва; Ленинград: Госиздат, 1926. 167 с.

9. Павлов И. П. Об уме вообще, о русском уме в частности // Физиологический журнал им. И. М. Сеченова. 1999. № 9-10. С. 1133-1139.

10. Ухтомский А. А. Доминанта. Статьи разных лет. 1887-1939. СПб.: Питер, 2002. 448 с.

11. Психология внимания / под ред. Ю. Б. Гиппенрейтер и В. Я. Романова. М.: ЧеРо, при участии издательства «Омега - Л», 2005. 858 с.

12. Основные свойства внимания. URL: https://studbooks.net/696365/psihologiya/osnovnye svoystva_vnimaniya (дата обращения 04.01.2019).

13. Уиинский K. Д. Человек как предмет воспитания: Опыт педагогической антропологии. Том II. М.: Книга по Требованию, 2014. 628 с.

14. Телегина Э. Д.Внимание и личность // Психология: Учебник для педагогических вузов / под ред. Б. А. Сосновского. М.: Юрайт-Издат, 2005. С. 179-190.

15. Теплов Б. М. Психология музыкальных способностей; [отв. ред. Э. А. Голубева, Е. П. Гусева, В. А. Кольцова, О. Е. Серова]. М.: Наука, 2003. 379 с.

16. Старчеус М. С. Слух музыканта. М.: МГК им. П.И. Чайковского, 2003. 640 с.

17. Музыкальная педагогика и исполнительство. Афоризмы, цитаты, изречения: учебное пособие / сост. и коммент. проф. Г. М. Цыпина. М.: МПГУ, 2011. 404 с.

18. Цыпин Г. М. Обучение игре на фортепиано: учебник для вузов. 2-е изд., испр. и доп. М.: Юрайт, 2016. 188 с.

19. Николаев В. Шопен-педагог. М.: Музыка, 1980. 93 с.

20. Шуман Р. Жизненные правила и советы молодым музыкантам; Пер. П. И. Чайковского. М.: Гос. изд-во. Муз. сектор, 1930 (нотопечатня Госиздата). 19 с.

21. Буасье А. Уроки Листа. СП-б.: Композитор Санкт-Петербург, 2003. 76 с.

22. Баренбойм Л. А. Рубинштейн-педагог // Музыкальная педагогика и исполнительство. Л.: Музыка, 1974. С. 171-195.

23. Баренбойм Л. А. Николай Григорьевич Рубинштейн: История жизни и деятельности. М.: Музыка, 1982. 277 с.

24. Сафонов В. И. Новая формула. Мысли для учащихся на фортепиано: учебное пособие. СПб.: Планета музыки, 2018. 32 с.

25. Обучение игре на фортепиано по Леймеру-Гизекингу. М.: Издательский дом «КлассикаXXI», 2009. $116 \mathrm{c}$.

26. Мартинсен $K . A$. Индивидуальная фортепианная техника на основе звукотворческой воли. М.: Музыка, 1966. 220 с.

27. Метнер Н. К. Повседневная работа пианиста и композитора: Страницы из записных книжек / сост. М. А. Гуревич, Л. Г. Лукомский. М.: Музыка, 2011. 72 с.

28. Щапов А. П. Фортепианная педагогика: Методическое пособие. М.: Советская Россия, 1960. $172 \mathrm{c}$. 
29. Прокофьев Г. П. Формирование музыканта-исполнителя-пианиста / под ред. действ. чл. АПН РСФСР Б. М. Теплова; Акад. пед. наук РСФСР. Ин-т психологии. М.: Изд-во Акад. пед. наук РСФСР, 1956. VIII. 480 с.

30. Савшинский С. И. Работа пианиста над музыкальным произведением. М.: Классика-ХХІ, 2004. $192 \mathrm{c}$.

31. Коган Г. М. У врат мастерства. М.: Классика-XXI, 2004. 136 с.

32. Станиславский K. C. Работа актёра над собой. Работа над собой в творческом процессе переживания. Дневник ученика. СПб.: Прайм-Еврознак, 2010. 408 с.

33. Нейгауз Г. Об искусстве фортепианной игры. Записки педагога: учебное пособие. СПб: Планета музыки, 2015. 256 с.

34. Софронищкий В. В. О своей работе // Пианисты рассказывают / сост., общ. ред. и вступ. ст. М. Соколова. М.: Советский композитор, 1979. С. 104-109.

35. Гинзбург Г. Р. Заметки о мастерстве // Вопросы фортепианного исполнительства. М., 1968, вып. 2. С. 61-70.

36. Жижина М. В. Формирование исполнительского внимания студентов-музыкантов: дис. ... канд. пед. наук. Саратов, 2001. 220 с.

Поступила в редакиию 15.01.2019; принята к публикации 15.03.2019

\section{Об авторе:}

Красовская Елена Павловна, профессор кафедры музыкально-исполнительского искусства Института изящных искусств федерального государственного бюджетного образовательного учреждения высшего образования «Московский педагогический государственный университет» (МПГУ) (улица Малая Пироговская, 1, строение 1. Москва, Российская Федерация, 119991), кандидат педагогических наук, доцент, krasovskaya_ep@mail.ru

\section{Автором прочитан и одобрен окончательный вариант рукописи.}

\section{REFERENCES}

1. Zwejg S. Mendel '-bukinist [Mendel dei libri]. Available at: http://lib.ru/INPROZ/CWEJG/mendel. txt (accessed: 02.01.2019).

2. Slovar' prakticheskogo psihologa [Dictionary by the practical psychologist] Compiled by S. Yu. Golovin: Minsk: Harvest; 1998. 551 p. (in Russian).

3. Hoffman J. Fortepiannaja igra: Otvety na voprosy o fortepiannoj igre [Piano play: Answers to questions of a piano play]. Moscow: Klassika-XXI Publ., 1998. 173 p. (in Russian).

4. Semenovskikh T. V. Fenomen «klipovogo myshlenija» v obrazovatel'noj vuzovskoj srede [Phenomenon of "clip thinking" in the educational high school environment] Internet-journal Naukovedenie, 2014, no. 5 (24). URL: https://elibrary.ru/item.asp?id=23039503 (accessed: 05.01.2019).

5. Ozhegov S. I., Shvedova N. Yu. Tolkovyj slovar' russkogo jazyka: 80000 slov i frazeologicheskih vyrazhenij [Defining dictionary of Russian: 80,000 words and phraseological expressions]. Rossijskaja akademija nauk. Institut russkogo jazyka im. V. V. Vinogradova. 4th ed., added. Moscow: Azbukovnik Publ., 1998. 944 p. (in Russian). 
6. Vinogradov V. V. Istorija slov [History of words]. URL: https://eknigi.org/gumanitarnye nauki/185503-istoriya-slov.html (accessed: 29.12.2018). (in Russian).

7. Titarenko M. L. Kitajskaya filosofiya. Enciklopedicheskij slovar' [Chinese philosophy. Encyclopedic Dictionary]. Moscow: Mysl' Publ., 1994. 652 p. (in Russian).

8. Bekhterev V. M. Refleksologija truda [Labor reflexology]; under general editorship and with foreword by A. A. Press. Moscow; Leningrad: Gosizdat Publ., 1926. 167 p. (in Russian).

9. Pavlov I. P. Ob ume voobshhe, o russkom ume v chastnosti [About the mind in general, about the Russian mind in particular] Fiziologicheskij zhurnal im. I. M. Sechenova. 1999, nos. 9-10. pp. 1133-1139 (in Russian).

10. Ukhtomsky A. A. Dominanta. Stat'i raznyh let. 1887-1939 [Dominant. Articles of different years. 1887-1939]. St. Petersburg.: Piter, 2002. 448 p. (in Russian).

11. Psikhologija vnimanija [Psychology of attention]. Edited by. Yu. B. Gippenreiter and V. Ya. Romanov. Moscow: CheRo, with assistance of Omega-L Publ., 2005. 858 p. (in Russian).

12. Osnovnye svojstva vnimanija [The basic properties of attention]. Available at: https://studbooks. net/696365/psihologiya/osnovnye_svoystva_vnimaniya (accessed: 04.01.2019).

13. Ushinsky K. D. Chelovek kak predmet vospitanija: Opyt pedagogicheskoj antropologii. Tom II [Man as a subject of education: the experience of pedagogH anthropology. Volume II]. Moscow: Kniga po Trebovaniju, 2014. 628 p. (in Russian).

14. Telegina E. D. Vnimanie i lichnost' [Attention and personality]. Psihologija: Uchebnik dlja pedagogicheskih vuzov [Psychology: Textbook for pedagogical universities]. Ed. B. A. Sosnowski. Moscow: Yurajt Publ., 2005. pp. 179-190 (in Russian).

15. Teplov B. M. Psikhologija muzykal'nykh sposobnostej [Psychology of musical abilities]. Ed. E. A. Golubeva, E. P. Guseva, V. A. Kol'tsova, O. E. Serova. Moscow: Nauka Publ., 2003. 379 p. (in Russian).

16. Starcheus M. S. Sluh muzykanta [Hearing of the musician]. Moscow: MGK im. P. I. Chajkovskogo Publ., 2003. 640 p (in Russian).

17. Muzykal'naja pedagogika $i$ ispolnitel'stvo. Aforizmy, citaty, izrechenija: uchebnoe posobie [Musical pedagogy and performance. Aphorisms, citations, sayings: manual]. Compiled and commented by prof. G. M. Tsypin. Moscow: MPGU Publ., 2011. 404 p. (in Russian).

18. Tsypin G. M. Obuchenie igre na fortepiano: uchebnik dlja vuzov [Training in playing a piano: the textbook for higher education institutions]. 2nd ed., revised and added. Moscow: Jurajt Publ., 2016. 188 p. (in Russian).

19. Nikolaev V. Shopen-pedagog [Chopin as teacher]. Moscow: Muzyka Publ., 1980. 93 p. (in Russian).

20. Schumann R. Zhiznennye pravila i sovety molodym muzykantam [Vital rules and advice to young musicians]; transl. by P. I. Chajkovsky. Moscow: Muz. Sector State Publ., 1930 (notopechatnja Gosizdata). 19 p. (in Russian).

21. Buas'e A. Uroki Lista [Liszt's lessons]. St. Petersburg: Kompozitor Sankt-Peterburg Publ., 2003. 76 p. (in Russian).

22. Barenboim L. A. Rubinshtejn-pedagog [Rubenstein as teacher]. Muzykal'naja pedagogika i ispolnitel'stvo [Musical pedagogy and performing]. Leningrad: Muzyka Publ., 1974. pp. 171-195 (in Russian).

23. Barenboim L. A. Nikolaj Grigor'evich Rubinshtejn: Istorija zhizni i dejatel'nosti [Nikolay Grigoryevich Rubenstein: Life story and activity]. Moscow: Muzyka, 1982. 277 p. (in Russian).

24. Safonov V. I. Novaja formula. Mysli dlja uchashhihsja na fortepiano. Uchebnoe posobie [New formula. Thoughts for pupils on a piano. Manual]. St. Petersburg: Planeta muzyki Publ., 2018. 32 p. (in Russian). 
25. Obuchenie igre na fortepiano po Lejmeru-Gizekingu [Leymer - Gizeking' learning to piano play]. Moscow: Klassika-XXI Publ., 2009. 116 p. (in Russian).

26. Martinsen K. A. Individual'naja fortepiannaja tehnika na osnove zvukotvorcheskoj voli [Individual piano technique based on the sound and creation will]. Moscow: Muzyka Publ., 1966, 220 p. (in Russian).

27. Medtner N. K. Povsednevnaja rabota pianista i kompozitora: Stranicy iz zapisnyh knizhek [The daily work of the pianist and composer: Pages from notebooks]. Compiled by M. A. Gurevich, L. G. Lukomskij. Moscow: Muzyka Publ., 2011. 72 p. (in Russian).

28. Shchapov A. P. Fortepiannaja pedagogika: Metodicheskoe posobie [Piano pedagogy: Methodical manual]. Moscow: Sovetskaja Rossiya Publ., 1960. 172 p. (in Russian).

29. Prokof'ev G. P. Formirovanie muzykanta-ispolnitelja-pianista [Formation of the performing musician-pianist]. Under editorship by act. member of APN RSFSR B. M. Teplov, Acad. ped. science RSFSR. In-t of psycology. Moscow: Publ. of Akad. ped. nauk RSFSR, 1956. VIII. 480 p. (in Russian).

30. Savshinskij S. I. Rabota pianista nad muzykal'nym proizvedeniem [Pianist work on the music piece]. Moscow: Klassika-XXI, 2004. 192 p. (in Russian).

31. Kogan G. M. U vrat masterstva [At the gate of mastery]. Moscow: Klassika-XXI, 2004. 136 p. (in Russian).

32. Stanislavskij K. S. Rabota aktjora nad soboj. Rabota nad soboj v tvorcheskom processe perezhivanija. Dnevnik uchenika [Work of the actor on himself. Work on in creative process of experience. Diary of the pupil]. St. Petersburg: Prajm-Evroznak Publ., 2010. 408 p. (in Russian).

33. Neygauz G. Ob iskusstve fortepiannoj igry. Zapiski pedagoga [About art of a piano play. Teacher's notes]: manual. St. Petersburg: Planeta muzyki Publ., 2015. 256 p. (in Russian).

34. Sofronickij V. V. O svoej rabote [About my work]. Pianisty rasskazyvayut [Pianists tell]. Compilation, editorship and foreword by M. Sokolov. Moscow: Sovetskij kompozitor, 1979. pp. 104-109 (in Russian).

35. Ginzburg G. R. Zametki o masterstve [Notes about mastery]. Voprosy fortepiannogo ispolnitel stva [Questions of piano performance]. Moscow, 1968, iss. 2, pp. 61-70 (in Russian).

36. Zhizhina M. V. Formirovanie ispolnitel'skogo vnimanija studentov-muzykantov [Formation of performing attention of musician students]. PhD Dissertation (Pedagogy). Saratov, 2001. 220 p. (in Russian).

Submitted 15.01.2019; revised 15.03.2019

\section{About the author}

Elena P. Krasovskaya, Associate Professor, Professor at the Department of Music Performing Art, at Moscow Pedagogical State University (MPGU) (Malaya Pirogovskaya Street, 1/1, Moscow, Russian Federation 119991), PhD of Pedagogical Sciences, krasovskaya_ep@mail.ru

The author has read and approved the final manuscript. 


\title{
ТЕОРИЯ МУЗЫКАЛЬНОГО ВОСПИТАНИЯ ПЕРВОЙ ТРЕТИ ХХ ВЕКА В КОНТЕКСТЕ РАЗВИТИЯ ОТЕЧЕСТВЕННОЙ ПЕДАГОГИКИ
}

\author{
С. И. Дорошенко, \\ Владимирский государственный университет \\ имени А. Г. и Н. Г. Столетовых» (ВлГУ), \\ г. Владимир, Российская Федерация, 600000
}

Аннотация. $B$ статье вылелены и проанализированы ключевые идеи отечественной педагогики первой трети XX века - идеи иелости и колплексности, свободь и творчества, труда (продуктивной деятельности), взаилодействия с социулол и учёта социальных влияний в соотнесении с их реализацией в музыкальнол воспитании этого периода. Анализируются работьє Б. В. Асафбьева, Н. Я. Брюсовой, В. Н. Шацкой и других теоретиков музыкального воспитания. Автор приходит к выводу о тол, что теория лузыкального воспитания первой трети XX века обогатила обшую педагогику художественно-эстетической интерпретацией и реализацией этих идей. Идеи иелости и колплексности в теории музыкального воспитания опираются на единство всех искусств, синкретичность, глубину и искренность детского художественного чувства. Идеи свободь и творчества отчасти базируются на основаниях свободного воспитания; они проявляют себя в позищии педагога в качестве исследователя, полошника, предлагающего, но не навязывающего музыкальный репертуар, видь музыкальной деятельности. Творчество в теории музыкального воспитания данного периода связывается с сочинениел музыки салили детьли - вьссшей фборлой продуктивной музыкальной деятельности воспитанников. Идея учёта социальных влияний, взаилодействия с социумол проявляется в исследовании музыки данной соииальной среды, в исследовательско-этнограббиеской позиции учителя и учеников. Своеобразие интерпретаиии и реализаиии ключевых педагогических идей первой трети ХХ века в теории музыкального воспитания позволяет говорить о салоценности и частично об опережающел влиянии этой теории на общую теорию педагогики.

Ключевые слова: педагогика, музыкальное воспитание, иелость, колплексность, свобода и творчество, взаилодействие с соииулол, первая треть ХХ века. 
История, теория и методика музыкального образования

Благодарности: автор выражает благодарность творческолу коллективу кафедрь методологии и технологий педагогики музыкального образования (заведуюший кафбедрой Э. Б. Абдуллин) за сотрудничество и поддержку в разработке данного актуального направления теории музыкального образования.

Для цитирования: Дорошенко С. И. Теория музыкального воспитания первой трети XX века в контексте развития отечественной педагогики // Музыкальное искусство и образование. 2019. Т. 7. № 1. С. 153-164.

\title{
THEORY OF MUSICAL EDUCATION OF THE FIRST THIRD OF THE XX CENTURY IN THE CONTEXT OF DEVELOPMENT OF DOMESTIC PEDAGOGY
}

\section{Svetlana I. Doroshenko,}

Vladimir State University named after Alexander and Nikolay Stoletovs, Vladimir, Russian Federation, 600000

\begin{abstract}
The article highlights and analyzes the key ideas of the national pedagogy of the first third of the twentieth century - the ideas of integrity and complexity, freedom and creativity, labor (productive activity), interaction with society and taking into account social influences - in relation to their implementation in the musical education of this period. The works by B. V. Asafiev, N. Ya. Bryusova, V. N. Shatskaya and other theorists of musical education are analyzed. The author comes to the conclusion that the theory of musical education in the first third of the twentieth century has enriched the general pedagogy with artistic and aesthetic interpretation and implementation of these ideas. The ideas of integrity and complexity in the theory of music education are based on the unity of all the arts, syncretism, depth and sincerity of children's artistic feeling. The ideas of freedom and creativity are partly based on the principles of free education; they manifest themselves in the position of a teacher as a researcher, assistant, offering, but not imposing a musical repertoire, types of musical activity. Creativity in the theory of musical education of this period is associated with composing music by the children themselves - the highest form of productive musical activity of pupils. The idea of taking into account social influences, interaction with society is manifested in the study of music of a given social environment, in the research and ethnographic position of the teacher and students. The peculiarity of the interpretation and implementation of key pedagogical ideas of the first third of the twentieth century in the theory of musical education allows us to speak about the intrinsic value and, in part, about the anticipating influence of this theory on the general theory of pedagogics.
\end{abstract}


Keywords: pedagogy, musical education, integrity, complexity, freedom and creativity, interaction with society, the first third of the twentieth century.

Acknowledgements: The author thanks the creative team of the Department of Methodology and Technology of the Music Education (Head of the ChairE. B. Abdullin) for cooperation and support in the development of this topical direction of the theory of musical education.

For citation: Doroshenko S. I. Theory of musical education of the first third of the XX centuryin the context of development of domestic pedagogy. Muzykal'noe iskusstvo $i$ obrazovanie = Musical Art and Education, 2019, vol. 7 , no. 1 , pp. 153-164.

\section{Актуальность обращения к теории музыкального воспитания первой трети XX века с позиций развития общей педагогики}

Анализ истории музыкального образования в соотношении с генезисом общей теории педагогики - при всей своей очевидности нерешённая и даже не вполне рефрлексируемая задача. В настоящее время, когда происходит осмысление предмета истории музыкального образования как науки [1], эта задача актуализируется и дифореренцируется. Возможны анализ соотношения общей дидактики и теории обучения в музыкальном образовании применительно к различным историческим периодам, а также рассмотрение становления социальной педагогики в целом и социально-педагогических тенденщий в музыкальном воспитании и образовании, целей, содержания и средств подготовки учителя в целом и подготовки учителя музыки в конкретных исторических ситуациях. В полной мере такой подход можно, на наш взгляд, осуществить лишь применительно к педагогике XX века. Это объясняется рядом причин.
Во-первых, отечественная педагогика - наука довольно молодая, и её классическая структура (история педагогики, дидактика, методики обучения) выделилась в последней трети XIX века.

Во-вторых, теория музыкального воспитания начала осмысливать себя во многом в связи с необходимостью обоснования музыки как обязательного школьного предмета. В явном виде это произошло на рубеже второго и третьего десятилетий $\mathrm{XX}$ века.

Период первой трети XX века очень показателен в плане соотношения развития общей педагогики и теории музыкального воспитания, так как именно в это время в музыкальном воспитании очевидным образом проявились влияния различных педагогических идей и концепций. Кроме того, именно в этот период теоретики музыкального воспитания сумели сказать своё слово в педагогической теории, и поэтому теория музыкального воспитания первой трети XX века не может рассматриваться только как ведомая, детерминированная общепедагогиче- 
скими тенденциями. Она не только сохраняла и провозглашала свою самоценность и самостоятельность, но и в определённой мере осуществляла влияние на общую теорию педагогики, фрактически возглавив процесс концептуализации эстетического воспитания в целом.

\section{Идеи целости и комплексности в отечественной педагогике первой трети XX века и в музыкальном воспитании этого периода}

Первая треть XX века привлекает внимание историков педагогики, в частности историков музыкального образования [2-5 и др.] бурным развитием инноващионных идей, радикальными попытками редормирования, столкновением различных педагогических концепций, в том числе привнесённых в Россию под влиянием педагогики США и Западной Европы.

Многие педагогические идеи, воспринятые советской педагогикой 1920-х годов, обсуждались и развивались ещё в конце XIX - начале XX века, и поэтому в развитии теоретикопедагогической мысли можно наблюдать не только ломку «устаревших» идей, но и преемственность. Остановимся на концептуальных идеях, непосредственно повлиявших на педагогику музыкального образования и на музыкально-образовательную практику в новаторских, экспериментальных учебных заведениях.

Ведущей идеей педагогики конца XIX - первой трети XX века была идея иелостности. В фрилософрии образования эту идею ярко выразил В. В. Розанов, иронизировавший по поводу того, что школьные предметы встречаются между собой только в виде учебников в рюкзаке гимназиста, и призывавший к реализации принципа целости [6, с. 96]. Проблема, обозначенная В. В. Розановым, была близка большинству педагоговтеоретиков его времени, и одним из наиболее ярких её выразителей в 1920-е годы стала Надежда Яковлевна Брюсова, предварившая программу по музыке концептуальной статьёй, в которой были выражены основные идеи эстетического воспитания того времени [7].

Н. Я. Брюсова противопоставляет «культуру разума» "культуре чувства», защищая последнюю. Полемический дух её статьи во многом обоснован потребностью преобразования ключевых педагогических позиций, в том числе реабилитации интуитивизма и реализации комплексности в преподавании искусства. При этом принцип целости, обозначенный в трудах В. В. Розанова, Надежда Яковлевна трактует как первичность целостного восприятия и миросозерцания по отношению к дальнейшему аналитическому постижению мира. «Они, - пишет о детях Н. Я. Брюсова, - только не проникали ещё во многие глубины жизни, не касались многих закрытых дверей, но целое они видели и чувствовали. Их миросозерцание не менее цельно и определённо, чем миросозерцание взрослых» [Там же, c. 8-9]. Заметим, что целость, свойственная внутреннему миру ребёнка, должна считаться основанием педагогической деятельности в любой сорере, хотя Н. Я. Брюсова обосновывает только необходимость музыкального воспитания на основе априорной убеждённости в полноте и целости музыкального чувства ре- 
бёнка: «Музыкальное чувство детей Уж, конечно, не менее глубоко и полно, чем чувство взрослых» [Там же].

\section{Идея целости соприкасается}

с идеей колплексности, реализованной в педагогике 1920-х годов. Именно в программах эстетического воспитания семилетней единой трудовой школы комплексность была, на наш взгляд, выражена наиболее органично и плодотворно (по сравнению с другими программами). В уже цитировавшейся статье Н. Я. Брюсова, по сути, сформулировала концепцию не только музыкального, но целостного художественно-эстетического воспитания. Надежда Яковлевна подчёркивала, что дети не разделяют искусство на различные виды искусства и творчество на различные виды творчества [Там же, с. 9]. Поэтому так естественна для них «игра в песню», музыкальная драматизация или то, «что мы, взрослые, назвали бы музыкальной драмой или оперой» [Там же].

Интересно, что, вводя в программы әстетического воспитания ритмику и обосновывая эту инновацию, педагоги 1920-х годов апеллировали к тому, что мы сейчас назвали бы надпредметными результатами обучения. Так, необходимость ритмики в школе объяснялась тем, что ритм есть «жизненная всеобъемлющая и всепроникающая сила» и именно эта сила становится ведущим «орудием воспитания» [8, с. 341]. Между прочим Н. Александрова, автор программы по ритмике, была весьма близка к идее единой художественной деятельности: по её мысли, ритм вводит «в те врата, из которых открыт доступ во все искусства» [Там же, с. 342].
Если обратиться ещё и к программам по изобразительному искусству, по драматизации, довольно легко защитить положение о том, что идеи целости и комплексности, провозглашённые в педагогике начала XX века, были наиболее глубоко прочувствованы и реализованы в сфрере эстетического воспитания. В области же музыки и ритмики можно увидеть и опережение педагогических идей своего времени.

\section{Свобода и творчество ребёнка}

Следующей концептуальной идеей педагогики первой трети XX века, которая оказалась близкой для педагогов-музыкантов, можно считать идею освобождения ребёнка. Эта идея, так же как и идеи целости и комплексности, не является продуктом сугубо револющионного, марксистского переосмысления педагогической теории. В 1900-е годы в России популярным стало так называемое «свободное воспитание»: педагогическое течение западного происхождения, основателем которого считается Ж.-Ж. Руссо [9]. Свободное воспитание в некоторой степени было присуще взглядам и педагогической деятельности Л. Н. Толстого [10], а затем активно развивалось К. П. Вентцелем [11].

В теории и практике музыкального воспитания идеи свободного воспитания можно увидеть в трудах В. Н. Шацкой [12] и С. Т. Шацкого [13], а также в уже цитировавшейся статье Н. Я. Брюсовой [7]. Пожалуй, именно в сфере музыкального воспитания в полной мере проявилась возможность осуществления детьми свободного выбора (или не выбора) инициируемой педагогом учебной дея- 
тельности, а также реализовалась исследовательская позиция учителя. Так, В. Н. Шацкая фриксировала в своих записях свободные музыкальные проявления детей: «27.01. $\mathrm{У}$ детей было настроение петь. Лена Петрова не хотела петь. Отвернулась к окну и совершенно ритмично выстукивала по окну, играла на рояле» [12, л. 6]. Как видим, субъектная позиция учителя выражалась в фриксации и оценивании свободных проявлений детей, а отнюдь не в обязательности организации конкретного вида деятельности.

В теории музыкального воспитания первой трети XX века прослеживается, хотя и не доминирует, нацеленность на композиторское творчество детей. Её можно связать и с идеей свободы, ибо создание собственных композиций - несомненное проявление свободы творчества, но можно увидеть в ней и связь с другой ведущей линией педагогики того времени - идеей труда, собственной продуктивной деятельноcmu. Н. Я. Брюсова, занимавшаяся с детьми сочинением музыкальных фрагментов, указывала на их метрическую свободу и своеобразие ритма. «Надо думать, - писала она, - что они правы, отстаивая свою метрическую свободу. Они мыслят более сложно, чем это можно уложить в элементарные тактовые границы. Возможно, что передают они свои мысли и не вполне точно, но это не значит, что надо их исказить другой, тоже неточной, записью» [14, с. 45]. Здесь нужно указать на отсутствие строгой границы между дореволюционными и послереволюционными педагогическими идеями: статья опубликована в 1929 году, но в ней
Н. Я. Брюсова описывает свой опыт 1915-1917 годов.

Идея детского творчества, детской продуктивной деятельности - одна из ведущих педагогических идей начала XX века, во многом давшая название единой трудовой школе. Трудовая деятельность понималась весьма широко, сближалась с проектной, с творческой. Поэтому детское композиторское творчество так органично вписывалось в теоретические установки созидаемой новой школы.

Детское композиторское творчество получило обоснование в новой науке - педологии, причём совершенно с неожиданной стороны. Видный педолог П. П. Блонский интерпретировал одну из педологических идей - биогенетическую - применительно к школьному воспитанию, в том числе музыкальному, и соотнёс её со своей возрастной периодизацией [15]. С биогенетических позиций он обусловливал комплексность эстетического воспитания в тесной связи с идеей трудовой школы. Краткое развёртывание в жизни ребёнка генезиса песни, которая, по Блонскому, имеет трудовое происхождение, соотносилось с возрастными периодами, которые, в свою очередь, соответствовали основным этапам развития человечества (например, ритмические импровизации дошкольника, по его представлению, соответствовали первобытно-общинной общественно-экономической формации).

Ребёнок, по мысли ведущих теоретиков музыкального воспитания 1920-х годов, создаёт собственный музыкальный мир. И в этом тоже прослеживается опережающее влияние теории музыкального воспитания на общую педагогику в целом. 


\section{Социально-педагогические тенденции в музыкальном воспитании}

В теории музыкального воспитания первой трети XX века прослеживается и общепедагогическая тенденция развития социальной педагогики. Идея активного включения ребёнка в жизнь социальной среды, участия его в преобразовательной сочиально-средовой деятельности в полной мере проявилась в музыкальном воспитании. Блестяще она была реализована в трудах и в практической работе С. Т. Шацкого и В. Н. Шацкой. Школа, по Шацкому, становилась центром культурной жизни социума, а также исследовательским центром, который продуцировал содержание и методы музыкального воспитания. В поле зрения педагога-музыканта таким образом попадал музыкальный быт социальной среды, собственный музыкальный опыт учеников. Перед учениками, помимо задач, связанных с освоением музыкальной культуры, вставали новые задачи: быть исследователями музыкальной культуры, её носителями, посредниками между школой и социальной средой.

Участие в средовых музыкальноэтнографических исследованиях помогало формировать содержание музыкального образования в школе и в хоровых кружках. Ученики В. Н. Шацкой получали задания собрать и записать тексты песен, которые поются в их семьях и в микросоциуме, спеть эти песни для записи педагогом-музыкантом, зафиксировать условия бытования той или иной песни (обряда): связь с календарным кругом или событиями в жизни среды, наличие танцевальных движений, требования к количеству исполнителей. Осознание ценности этой деятельности стимулировало познавательную активность учащихся. Валентина Николаевна писала: «Учащиеся второй ступени, особенно в одной нашей школе, выказали большой интерес к исследованию песен и очень помогали. Один из учеников самостоятельно подготовил названия и текст 25 песен из своей деревни. Девочки разучивали самые песни, переписывали текст...» [16, с. 86]. Учащиеся первой ступени собирали сведения о том, при каких условиях какие песни поются, когда появляются новые песни, кто их приносит. Интересно, что эти знания считались важным аспектом музыкального воспитания наряду с элементами музыкальной грамоты, сведениями о композиторах, исполнителях.

Широкий процесс социального воспитания на Первой опытной станции Наркомпроса поддерживался педагогами-музыкантами. В. Н. Шацкая вела хоровые кружки для взрослых, организовывала концерты и лекции-беседы, на которых присутствовали все желающие. Ученики нередко ставились в субъектную позицию учителей: руководителями хоровых кружков для населения были учащиеся второй ступени. $К$ занятиям допускались все желающие, а также те, кто пришёл посмотреть и послушать. Так, в хоровой кружок Народного дома в Угодске, которым руководила сама В. Н. Шацкая, входили члены драматического кружка, местного кружка самообразования и некоторые любители пения. Программа работы кружка включала 
в себя слушание музыки и разучивание песен, выбранных аудиторией из исполненных Валентиной Николаевной. «Те песни, которые особенно нравились, я предлагала разучить тут же на занятии, - писала она. - В разучивании песен принимали участие не только члены кружка, но и значительная часть "публики”» $[17$, с. 23$]$. В результате социально-педагогическое взаимодействие приобретало многомерность, становилось реальным прототипом того, что мы сейчас называем непрерывным образованием.

Кроме того, социально-педагогические тенденции детерминировали обращение к регионализации музыкального воспитания, к опоре на местный опыт, национально-культурные традиции. Поскольку эти тенденции легко соотносятся с музыкально-этнографической работой, то в этом направлении теория музыкального воспитания едва ли не лидировала в развитии общепедагогической мысли, направленной на учёт местных традиций и особенностей. Эту тенденцию в музыкальном образовании поддерживал и развивал Б. В. Асафьев [18]. Соединяя в себе музыковеда и теоретика музыкального воспитания, Борис Владимирович глубоко осмыслил значимость изучения народного музыкального искусства на месте его бытования, в связи со всем строем интонаций окружающей среды [19, с. 12]. Его музыкально-этнографическая деятельность пришлась как раз на 1920-е годы, так что идея учёта местных средовых влияний, собирания и сохранения культурных ценностей в музыкальном воспитании оказалась методологически и теоретиче- ски обоснованной, а главное - вполне понятной педагогам-музыкантам «на местах». Так что и в этом отношении теория музыкального воспитания не столько следовала за общепедагогической мыслью, сколько являла собой образцы бережного отношения к местным культурным традициям, их фиксации, сохранения и поддержания.

Какова же причина постепенного снижения значимости музыкального воспитания в советской педагогике к 1930-м годам? Основной акцент, особенно к концу 1920-х годов, делался не столько на учёт средовых влияний, сколько на идеологически ориентированное преобразование среды. В педологии, которая брала на себя функции теоретической педагогики, роль социальной среды оценивалась очень высоко. Так, А. Б. Залкинд писал о «колоссальной роли... социальной среды в развитии форм и содержания человеческой активности» [20, c. 10]. Однако к 1930-м годам происходит формализация ряда видов социально ориентированной деятельности, например: «Зав. внеклассной просветительской работой связан с работой кружков, с театральной, музыкальной комиссиями, заботится об организации празднеств, внеочередных докладах... Секретарь объединяет всё, делаемое учкомом...» [21, c. 107]. Музыкальное воспитание всё больше становилось востребованным лишь в пропагандистских целях. Социально-преобразовательная деятельность, конечно, имела место в теории и практике музыкального воспитания через деятельность кружков, участие в праздниках и пр. Но всё же идея преобразования среды, на наш взгляд, оказалась ахиллесо- 
вой пятой музыкального воспитания рассматриваемого периода. Здесь оно (музыкальное воспитание) не только не лидировало, но и серьёзно уступало трудовому, социально-историческому, естественно-научному.

\section{Заключение}

Если сопоставить параллельные, но несовпадающие процессы развития общей педагогики и теории музыкального воспитания в первой трети XX века, то аргументированно предполагаемой, если не доказанной, становится мысль о том, что теория музыкального воспитания по многим ведущим позициям, в частности по глубине и своеобразию интерпретации ведущих идей, опережала общую теорию педагогики.

Идеи целости и комплексности в музыкальном воспитании связываются не только с взаимодействием разных предметных сфер, но прежде всего с целостностью детского миросозерцания, единством художественного мышления. Смысл музыкального и, шире, эстетического воспитания видится в открытии возможностей изначально цельного интуитивного, чувственного постижения мира; педагоги-музыканты близко подходят к целевым ориентирам, аналогичным сегодняшним надпредметным результатам обучения.

Идеи свободы и творчества ребёнка в музыкальном воспитании прямо демонстрируют возможность субъектного выбора с его стороны и доминирование исследовательской и поддерживающей позиции со стороны учителя. При этом защищается своеобразие художественного мышления и творчества ребёнка (например, метрическая и ритмическая свобода). Вершиной развития данных идей является целевая ориентация на созидание и освоение ребёнком собственного музыкального мира в процессе сочинения музыкальных композиций. Идеи свободы и творчества были соотнесены с возрастными этапами развития детей (биогенетики предлагали идентифицировать эти этапы с периодами исторического развития человечества).

Социально-педагогические тенденции в музыкальном воспитании активно реализовывались через изучение и включение в музыкальнопедагогический процесс музыкального быта социальной среды. Учёт местных, региональных традиций музицирования в музыкальном воспитании опирался на отредлексированные музыковедческие позиции и опыт изучения народного музыкального искусства. Однако доминирование охранительных, а не преобразовательных традиций в этом направлении деятельности не вполне позволяло музыкальному воспитанию «идти вровень» с общепедагогическими тенденциями своего времени.

Соотношение исторических линий развития общей педагогики и педагогики музыкального образования требует специального серьёзного изучения и не может ограничиться рамками отдельной статьи. Поэтому данные выводы нужно интерпретировать как попытку постановки проблемы, но далеко не как её решение. 


\section{БИБЛИОГРАФИЯ}

1. Николаева E. В. Перспективы развития в России истории музыкального образования как науки // Вестник кафедры ЮНЕСКО «Музыкальное искусство и образование». 2016. № 1 (13). С. 142-149.

2. Адищев В. И. Музыкальное воспитание детей в первые годы после Октября (1917-1920 гг.): учеб. пособие. Пермь : Изд-во ПГПИ, 1991. 115 с.

3. Апраксина, О. А. Методика музыкального воспитания в школе. М.: Просвещение, 1983. 224 с.

4. Морозова С. Н. Далёкое - близкое (Б. Л. Яворский о музыкальном воспитании детей) // Музыкальное воспитание в школе: сборник статей. Вып. 16. М.: Музыка, 1985. С. 14-19.

5. Минор Н. Н. История музыкального образования: учеб. пособие. Саратов: Научная книга, 2011. $65 \mathrm{c}$.

6. Розанов В. В. Сумерки просвещения / сост. В. Н. Щербаков. М.: Педагогика, 1990. 624 с.

7. Брюсова Н. Я. Музыка в школе // Материалы по общему музыкальному образованию в школе / Н. Я. Брюсова, А. А. Шеншин, М. М. Койранская; под общ. ред. Музыкальной секции, Отдела единой труд. школы Нар. ком. по просвещению. М.: ГИЗ, 1921. С. 5-11.

8. Программы для I и II ступени семилетней единой трудовой школы. М.: ГИЗ, 1921. 359 с.

9. Руссо Ж.-Ж. Эмиль, или О воспитании. М.: Мультимедийное издательство Стрельбицкого, 2016. URL: https://mybook.ru/author/zhan-zhak-russo/emil-ili-o-vospitanii/read/ (дата обращения: 03.02.2019).

10. Толстой Л. Н. Яснополянская школа за ноябрь и декабрь месяцы. URL: https://knigogid.ru/ books/590972-yasno-polyanskaya-shkola-za-noyabr-i-dekabr-mesyacy/toread (дата обращения: 03.02.2019).

11. Вентиель К. Н. К вопросу о практическом осуществлении Дома свободного ребёнка. Черновик «Идеальная школа будущего». «Мораль жизни и свободного идеала» // Научный архив РАО. Ф. 23. Оп. 1. Ед. хр. 73.154 л.

12. Шаикая В. Н. Музыкальная работа в детском саду. Материалы Музыкальной комиссии. 1916-1923. Научный архив РАО. Ф. 1. Оп. 1. Ед. хр. 99. 73 л.

13. Шацкий С. Т. Педагогические сочинения: в 4 т. Т. 1 / под ред. И. А. Каирова. М.: Просвещение, 1962. $503 \mathrm{c}$.

14. Брюсова Н. Я. Детское музыкальное творчество (Опыт, проведённый в 1915-1917 гг.) // Искусство в школе. 1929. № 6-7. С. 40-60.

15. Блонский П. П. Отношение подростка к искусству и красоте // Научный архив РАО. Ф. 112. Оп. 1. Ед. хр. 1. 15 л.

16. Шацкая В. Н. Песни и быт деревни (Из работ Первой опытной станции Наркомпроса) // Вестник просвещения. 1925. Июнь. С. 78-89.

17. Валентина Николаевна Шацкая: К 90-летию со дня рождения (Очерк жизни и творчества) / Педагогическое общество, Центральный совет, Институт эстетического воспитания; сост. О. А. Апраксина. М.: Просвещение, 1972. 64 с.

18. Асафьев Б. В. Русская народная песня и её место в школьном музыкальном воспитании и образовании // Избранные статьи о музыкальном просвещении и образовании. М.: Музыка, 1965. С. $102-117$.

19. Асафьев Б. В. О народной музыке. Л.: Музыка, 1987. 248 с.

20. Залкинд А. Б. Педология в СССР. М.: Работник просвещения, 1929. 83 с.

21. Пинкевич А. П. Педагогика: в 2 т. Т. 2. М.: Работник просвещения, 1929. 264 с. 


\section{Поступила 05.02.2019; принята к публикаиии 15.03.2019.}

\section{Об авторе:}

Дорошенко Светлана Ивановна, профрессор кафредры педагогики Педагогического института ФГБОУ ВО «Владилирский государственный университет илени А. Г. и Н. Г. Столетовых» (ВлГУ) (ул. Горького, 87, 2. Владимир, Российская Федераиия, 600000), доктор педагогических наук, доцент, cvedor@mail.ru

Авторол прочитан и одобрен окончательный вариант рукописи.

\section{REFERENCES}

1. Nikolaeva E. V. Perspektivy razvitiya v Rossii istorii muzykal'nogo obrazovaniya kak nauki [Prospects for the development of the history of music education as a science in Russia]. Vestnik kafedry UNESCO "Muzykal'noe iskusstvo i obrazovanie" = Bulletin of the UNESCO Chair “Musical Arts and Education”, 2016, no. 1 (13), pp. 142-149 (in Russian, abstract in English).

2. Adishchev V. I. Muzykal'noe vospitanie detej v pervye gody posle Oktyabrya (1917-1920 gg.) [Musical education of children in the first years after October (1917-1920)]. Perm': PGPI Publ., 1991, 115 p. (in Russian).

3. Apraksina O. A. Metodika muzykal'nogo vospitaniya $v$ shkole [Method of musical education at school]. Moscow: Prosveshchenie Publ., 1983, 224 p. (in Russian).

4. Morozova S. N. Dalekoe - blizkoe (B. L. Yavorsky o muzykal'nom vospitanii detej) [Far - close (B. L. Yavorsky about the musical education of children)]. Muzykal'noe vospitanie $v$ shkole: sbornik statej [Musical education in school: collected papers]. Issue 16. Moscow: Muzyka Publ., 1985, pp. 14-19 (in Russian).

5. Minor N. N. Istoriya muzykal'nogo obrazovaniya [History of Music Education]. Saratov: Nauchnaya kniga Publ., 2011, 65 p. (in Russian).

6. Rozanov V. V. Sumerki prosveshcheniya [Twilight of education]. Compiled by V. N. Shcherbakov. Moscow: Pedagogika Publ., 1990, 624 p. (in Russian).

7. Bryusova N. Ya. Muzyka v shkole [Music at school]. Muzyka v shkole: Materialy po obshchemu muzykal'nomu obrazovaniyu v shkole [Music at school: Materials on the general music education at school]. N. Ya. Bryusova, A. A. Shenshin, M. M. Kojranskaya. Under a general edition with Musical section of Department of uniform labor school. Moscow: GIZ Publ., 1921, pp. 5-11 (in Russian).

8. Programmy dlya I i II stupeni semiletnej edinoj trudovoj shkoly [Programs for the I and II levels of the seven-year unified labor school]. Moscow: GIZ Publ., 1921, 359 p. (in Russian).

9. Rousseau J. J. Emil', ili $O$ vospitanii [Emil, or About Education]. Moscow: Mul'timedijnoe izdatel'stvo Strel'bitskogo Publ., 2016. Available at: https:/mybook.ru/author/zhan-zhak-russo/ emil-ili-o-vospitanii/read/ (accessed: 3 February 2019) (in Russian).

10. Tolstoj L. N. Yasnopolyanskaya shkola za noyabr'i dekabr' mesyatsy [Yasnaya Polyana school for of November and December months]. Available at: https://knigogid.ru/books/590972-yasnopolyanskaya-shkola-za-noyabr-i-dekabr-mesyacy/toread (accessed: 3 February 2019) (in Russian).

11. Venttsel' K. N. K voprosu o prakticheskom osushchestvlenii Doma svobodnogo rebenka. Chernovik "Ideal'naya shkola budushchego". "Moral' zhizni i svobodnogo ideala" [On the question of the practical implementation of the House of a Free Child. Draft "The ideal school of the future". 
"The moral of life and the free ideal". Scientific archive of the Russian Academy of Education]. Nauchnyj arkhiv RAO, coll. 23, aids 1, item 73, p. 154 (in Russian).

12. Shatskaya V. N. Muzykal'naya rabota v detskom sadu. Materialy Muzykal'noj komissii. 19161923 [Musical work in kindergarten. Materials of the Music Commission. 1916-1923. Nauchnyj arkhiv RAO, coll. 1, aids 1, item 99. 73 p. (in Russian).

13. Shatsky S. T. Pedagogicheskie sochineniya [Pedagogical compositions]. In 4 volumes. Vol. 1. Under the editorship of I. A. Kairov. Moscow: Prosveshchenie Publ., 1962. 503 p. (in Russian).

14. Bryusova N. Ya. Detskoe muzykal'noe tvorchestvo (Opyt, provedennyj v 1915-17 gg.) [Children's musical creativity (Experience conducted in 1915-1917 years)]. Iskusstvo v shkole [Art in school], 1929, no. 6-7, pp. 40-60 (in Russian).

15. Blonsky P. P. Otnoshenie podrostka $\mathrm{k}$ iskusstvu i krasote [The attitude of a teenager to art and beauty]. Nauchnyj arkhiv RAO, coll. 112, aids 1, item 1. 15 p. (in Russian).

16. Shatskaya V. N. Pesni i byt derevni (Iz rabot Pervoj opytnoj stantsii Narkomprosa) [Songs and life of the village (From the work of the first experimental station of the People's Commissariat of Education]. Vestnik prosveshcheniya, 1925, June, pp. 78-89 (in Russian).

17. Valentina Nikolaevna Shatskaya. K 90-letiyu so dnya rozhdeniya (Ocherk zhizni i tvorchestva) [Valentina Nikolaevna Shatskaya. to the 90th anniversary of the birth (Essay on life and creativity)]. Compiler O. A. Apraksina. Moscow: Prosveshchenie Publ., 1972, 64 p. (in Russian).

18. Asaf'ev B. V. Russkaya narodnaya pesnya i ee mesto v shkol'nom muzykal'nom vospitanii i obrazovanii [Russian folk song and its place in the school music education]. Izbrannye stat' $i$ o muzykal'nom prosveshchenii i obrazovanii [Selected articles on music education]. Moscow: Muzyka Publ., 1965, pp. 102-117 (in Russian).

19. Asaf'ev B. V. O narodnoj muzyke [About folk music]. Leningrad: Muzyka Publ., 1987, 248 p. (in Russian).

20. Zalkind A. B. Pedologiya v SSSR [Pedology in the USSR]. Moscow: Rabotnik prosveshcheniya Publ., 1929, 83 p. (in Russian).

21. Pinkevich A. P. Pedagogika [Pedagogy]. In 2 volumes. Vol. 2. Moscow: Rabotnik prosveshcheniya Publ., 1929, 264 p. (in Russian).

Submitted 05.02.2019; revised 15.03.2019.

About the author:

Svetlana I. Doroshenko, Associate Professor, Professor at the Department of Pedagogics of the Pedagogics Institute Vladivir State University named after Alexander and Nikolay Stoletovs (Gorky Street, 87, Vladimir, Russian Federation, 600000), Doctor of Pedagogical Sciences, cvedor@mail.ru

The author has read and approved the final manuscript. 


\section{МОТИВАЦИЯ БУДУЩИХ МУЗЫКАНТОВ- ПЕДАГОГОВ К ВЫБОРУ ЗАОЧНОЙ ФОРМЫ ОБУЧЕНИЯ И ОЦЕНИВАНИЕ ЕЁ СОВРЕМЕННОГО СОСТОЯНИЯ}

\section{Е. Н. Шумилова,}

Ленинградский государственный университет им. А. С. Пушкина, г. Пушкин, Санкт-Петербург, Российская Федерация, 196605

Аннотация. Автор разлышляет о специббике заочного музыкально-педагогического образования, которое лногили воспринилается в негативной коннотации, - сокращённое количество учебных дисциплин, в первую очередь индивидуальньх занятий, а также то, что заочное образование чаще всего бывает платныли и изначальный уровень абитуриентов довольно слабый. Однако чётких критериев сравнительного качества диплолов дневной и заочной бборль обучения нет. Тел более в музыкальной профбессии, где «штучное», индивидуальное обучение актуализирует не только профбессиональнье знания и уления, но и борлирование личностных качеств будущего специалиста. При этол следует развести два понятия - "заочное обучение" и "дистанционное обучение». Исследований, которые занилались бь проблелатикой иленно заочного музыкально-педагогического образования, практически нет. Как правило, существуюшие нелногочисленные работы по заочнолу обучению педагогическил специальностял, совершенно не учитыьвают специбику проббессии учителя музыки, наприлер в части творческой составляющей учебного процесса или развития исполнительских улений. На сегодняшний день наиболее залетные исследовательские лакунь - это актуализация контекстного подхода и исследование мотивационного колпонента в заочнол обучении. Автор анализирует данные разработанной ил подробной анкеты для студентов-заочников с инборлацией о реальнол и предполагаелол лесте работы будущих выпускников, их мотивации на заочное обучение, степени удовлетворённости такил обучениел, его достоинствах и недостатках, уровне музыкальной подготовки будущих педагогов-музыкантов, их конкретных проббессиональных проблелах и т. д. Ответы студентов показали, что в музыкально-педагогической профбессии существует тендениия, связанная с публичныли выражениел музыкального творчества, актуализацией не только образовательной и воспитательной, но и просветительской составляющей учебного процесса. Полило исполнительских качеств учителя музыки, крайне востребован- 
История, теория и методика музыкального образования

нылии становятся те уления и навыки, которые ешё совсел недавно казались несущественныли, наприлер такие, как организационные, режиссёрские, лекторские, менеджерские. По мнению автора, в заочнол музыкально-педагогическол обучении гораздо легче развить способности педагогов в этол плане, так как, с одной стороны, есть знаниевая база, а с другой - конкретная профессиональная ситуация, знаколая и близкая студенту-заочнику и педагогу в однол лице. В этой контекстной парадигле заложен мощный стилул для мотивированности студента на максимальную отдачу "всего себя" учебнолу процессу и, соответственно, оптилальнолу сочетанию и взаимодополнению учёбы и профбессиональной деятельности.

Ключевые слова: заочное музыкально-педагогическое образование, мотивационный аспект, контекстный подход, музыкальное творчество, просветительская фбункия, восприятие музыки.

Благодарности: Статья написана в русле научно-исследовательского направления кафедры музыкальных дисииплин Ленинградского государственного университета илени А. С. Пушкина "Историко-теоретические проблель музыкального образования: традииии и новаторство в XXI веке». Автор сердечно благодарит своих коллег по кафедре.

Для цитирования: Шулилова $E$. H. Мотивация будущих музыкантовпедагогов к выбору заочной фрормы обучения и оценивание её современного состояния // Музыкальное искусство и образование. 2019. Т. 7. № 1. C. $165-176$.

\title{
MOTIVATION OF FUTURE MUSICIANS-TEACHER TO THE CHOICE OF DISTANCE LEARNING AND EVALUATION OF ITS CURRENT STATE
}

\section{Elena N. Shumilova,}

Pushkin Leningrad State University, Pushkin, St. Petersburg, Russian Federation, 196605

\begin{abstract}
The author reflects on the specifics of distance musical and pedagogical education, which is perceived by many in a negative connotationa reduced number of academic disciplines, first of all, individual lessons. And also - the important factor that distance education is often paid and the initial level of students is rather weak. However, there are no clear criteria for the comparative quality of full-time and part-time diplomas. Moreover, in the music profession, where individual training actualizes not only professional knowledge and skills, but also the formation of personal
\end{abstract}


qualities of the future specialist. at the same time, it is necessary to separate two concepts - "correspondence" and "distance" learning. There is practically no research that would deal with the problems of distance musical and pedagogical education. As a rule, those few works that exist on correspondence training of pedagogical specialties do not take into account the specifics of the profession of music teacher, for example, in terms of the creative component of the educational process or the development of performing skills. to date, the most noticeable research gaps are, first of all, the actualization of the contextual approach and the study of the motivational component in distance learning. The author analyzes the data developed by him a detailed questionnaire for part-time students with information about the real and intended place of work of future graduates, their motivation for distance learning, the degree of satisfaction with such training, its advantages and disadvantages, the level of musical training of future teachers, musicians, their specific professional problems, etc. The students' answers showed that there is a powerful trend in the musical and pedagogical profession associated with the public expression of musical creativity, the actualization of not only education and upbringing, but also the enlightenment component of the educational process. In addition to the performance qualities of a music teacher, those skills that have only recently seemed to be insignificant, such as organizational, directorial, lecturers, and managerial ones, have become extremely popular. According to the author, in the correspondence musical and pedagogical education it is much easier to develop the abilities of teachers in this regard, since, on the one hand, there is a knowledge base, and on the other - a specific professional situation, familiar and close to the correspondence student and teacher in one person. In this contextual paradigm laid a powerful lever of motivation of part-time students to maximize the "whole" of the educational process and, accordingly, the optimal combination and complementarity of study and professional activities.

Keywords: distance musical and pedagogical education, motivational aspect, contextual approach, musical creativity, educational function, perception of music.

Acknowledgements: The article is written in line with the research direction of the Department of music disciplines of LSU named after A. S. Pushkin "Historical and theoretical problems of music education: traditions and innovation in the XXI century", the author sincerely thanks his colleagues in the Department.

For citation: Shumilova E. N. Motivation of future musicians-teacher to the choice of distance learning and evaluation of its current state. Muzykal'noe iskusstvo i obrazovanie = Musical Art and Education, 2019, vol. 7, no. 1, pp. 165-176. 


\section{Введение}

Когда речь заходит о заочном образовании, в частности музыкально-педагогическом, нередко возникает негативная коннотащия, в различной степени выраженная. Такая форма обучения многими воспринимается как ущербная, изначально как бы «второго сорта». Надо признать, что для этого есть веские основания: усечённые учебные планы, сокращённое количество учебных дисциплин, в первую очередь индивидуальных занятий, а также то, что заочное образование чаще всего бывает платным и начальный уровень абитуриентов довольно слабый.

Тем не менее не всё так однозначно. Чётких критериев сравнительного качества дипломов дневной и заочной формы обучения нет, тем более в музыкальной профессии, где «штучное», индивидуальное обучение фрормирует не только профессиональные знания и умения, но и личностные качества будущего специалиста. И как фиксировать уровень и качество обучения выпускников? Оценками в дипломе? Местом работы, более или менее престижным? Тогда как быть с громадной просветительской, зачастую тяжёлой повседневной работой в небольших провинциальных школах, подростковых клубах, детских садах? Даже если сравнивать только по этим критериям, то увидим явную неоднозначность профессиональных индикаций. А есть ещё много других. Например, количество выпускников, оставшихся в профрессии. Нам представляется, что в этом отношении заочники вполне могут конкурировать с выпускниками дневных отделений.

При характеристике заочного образования следует развести два понятия - «заочное обучение» и «дистанционное обучение». Считается, что дистанщионное обучение является модифицированной формой заочного образования. Вместе с тем ряд авторов (А. А. Андреев [1], Е. С. Полат [2], В. И. Овсянников [3] и др.) высказывают мнение, что дистанционное обучение становится альтернативой заочной формы, но лишённой его недостатков. На наш взгляд, дистанпцонные методы обучения могут (а в некоторых случаях и должны) присутствовать и в дневной форме обучения. Поэтому противопоставлять, а тем более идентифицировать эти понятия ни в коем случае нельзя.

\section{Актуальность и степень разработанности проблемы}

Заочное обучение в системе музыкального образования, где изначально предполагается максимальная концентрация на индивидуальных занятиях, чаще всего определяется фактором необходимости получить высшее образование в тех случаях, когда получить стандартное дневное образование не представляется возможным. Практически нет исследований, которые были бы посвящены проблематике именно заочного музыкально-педагогического образования. Как правило, имеющиеся немногочисленные работы по заочному обучению широкого спектра педагогических специальностей, совершенно не учитывают специфику профрессии учителя музыки, например в части творческой составляющей учебного процесса или развития исполнительских умений и т. д.

Примечательно, что кандидатские диссертации по проблематике заочного обучения защищаются в провинциальных вузах, где образовательные, 
социальные, организационные, коммуникативные и другие вопросы стоят наиболее остро. Это работы Т. Н. Добрыниной [4] (Новосибирск, 2003), Г. С. Вяликовой [5] (Коломна, 2006), Е. Н. Устюжаниновой [6] (Самара, 2006), Л. Ф. Грищенко [7] (Сургут, 2002), Н. В. Тариновой [8] (Казань, 2018), Н. А. Александровой [9] (Саратов, 2008), И. И. Гурьевой [10] (Ставрополь, 2007) и некоторых других.

Наибольший вклад в развитие дидактики высшего педагогического заочного образования внесли труды И. Г. Шамсутдиновой [11]. В её исследованиях подробно разработана дидактическая модель, описаны методы и организационные формы обучения студентов-заочников. Подвергнуты специальному анализу основные проблемы высшей заочной школы, к которым относятся совмещение учебной и производственной деятельности; значительно меньший объём аудиторных занятий и большая роль самостоятельной работы, опосредованность коммуникации между преподавателем и студентом, сессионная форма организации учебных занятий.

В перечисленных (а также в других) работах подробно освещались педагогические условия применения интерактивных фрорм обучения, организация самостоятельной образовательной деятельности студентов-заочников, педагогическое стимулирование профессиональной компетентности учителя в условиях заочной формы обучения, вопросы модернизации заочного обучения как важнейшего условия повышения качества продессиональной подготовки студентов и многие другие аспекты.

Вместе с тем заметны и некоторые исследовательские лакуны. Это, в пер- вую очередь, актуализация контекстного подхода и исследование мотивационного компонента подготовки будущего спещиалиста в парадигме заочного обучения. Контекстный подход необычайно важен в условиях, когда студент уже находится в музыкально-педагогической профессии, которая имеет широчайший спектр. В образовании это учреждения от дошкольного до вузовского уровня. А есть и другие сферы (и их сочетания) применения профессиональных качеств: административная, просветительская, исполнительская, методическая и т. д. И везде своя специфика, являющаяся фрактором успешности профессиональной деятельности выпускника-заочника музыкально-педагогического вуза.

\section{Мотивация выбора заочной формы обучения и оценивание её современного состояния по результатам констатирующего обследования}

Для изучения мотивации студентов - будущих музыкантов-педагогов, выбравших заочную форму обучения, - и оценивания ими современного состояния высшего музыкальногопедагогического образования была разработана достаточно подробная анкета. Анкетирование проводилось на протяжении двух лет, в 2017/2018 и 2018/2019 учебных годах на кафедре музыкальных дисциплин Ленинградского государственного университета имени А. С. Пушкина с первого по пятый курс заочного отделения.

Было опрошено 83 студента, это более 90\% от общего числа обучающихся на этой кафредре. Возрастная амплитуда респондентов оказалась необычайно широкой - от 18 до 64 лет. Из них профильное среднее специаль- 
ное образование имели $74 \%$ опрошенных, остальные до поступления в университет обучались в детских музыкальных школах или студиях (чаще всего вокальных). Кроме того, 18\% студентов получали музыкально-педагогическое образование как второе высшее. Это были выпускники довольно престижных вузов, например Литературного института имени А. М. Горького, медицинских институтов, Православного университета в Петербурге, Высшей школы экономики, фрилологического фракультета РПГУ имени А. И. Герцена, некоторых технических вузов и т. д. Среди студентов кафедры оказался даже кандидат медищинских наук. В большинстве своём это взрослые, часто семейные люди.

Причиной выбора заочной формы обучения (это один из вопросов анкеты) чаще всего указывалась возможность совмещать учёбу с работой, что было вполне предсказуемо, или отсутствие в их родном городе заочного обучения по этой специальности.

Так, например, ответ Екатерины А. соответствовал самому распространённому варианту: «Не видела себя в будушел кониертныли исполнителел. А в педагогической деятельности нужно набираться опьыта, и, чел раньше окунёшься в эту деятельность, тел лучше» ${ }^{1}$. Среди других вариантов ответов: полная трудовая занятость, наличие семьи и детей, отсутствие ограничений по возрасту. Только несколько человек в качестве причины отметили недостаточное количество баллов для поступления в другой вуз.

Один из главных вопросов анкеты заключался в обозначении достоинств и недостатков заочного музыкально- педагогического обучения. В числе отрицательных сторон будущие учителя музыки называли: длительность обучения (пять лет для получения степени бакалавра); невозможность качественно освоить весь учебный материал; совмещение работы с учёбой (эта причина фригурирует как в положительной, так и в негативной коннотации); слишком плотное расписание, большое количество экзаменов и зачётов в короткие промежутки времени; бытовую неустроенность. Приведём, в частности, фррагмент ответа Евгения И.: «...иногда програлила интересного и необходимого предмета изучается очень быстро и не хватает врелени, чтобы углубиться в предмет, нужную инфборлацию приходится искать салостоятельно, не илея возложности усльшать мнение проббессионала».

Положительные стороны заочного обучения, по мнению студентов, - это получение опыта и стажа работы, экономия времени и материальных средств (часть опрошенных училась в ЛГУ на бюджетной основе, остальные - примерно треть - на платной). Особый интерес в этом плане представляют следующие ответы. Любовь Г. отмечает: «Полученные знания ложно сразу приленить на рабочел месте и двигаться вперёд по карьерной лестнице, нет ограничений в возрасте, во вреля обучения обшаешьсл с людьли, которые уже илеют значительный опьт в жизни, могут дать полезный совет». Из контекста ответа добавим, что здесь имеется в виду общение не только с преподавателями, но и с сокурсниками.

По мнению Алексея И., «за вреля учёбь поднялся уровень салоразви-

\footnotetext{
1 Здесь и далее орфографояя и пунктуация в ответах респондентов частично изменены.
} 
тия и салоподготовки, выработалась заинтересованность в обучении. Плюсь - развивается способность к салоорганизации, минусььнедостаточность часов в програлме по индивидуальньлм предлетал (фортепиано, вокал)».

Екатерина Л. обращает внимание на то, что заочникам "...nриходится салостоятельно осваивать материал, благодаря челу они становятся более ответственнылии и терпеливылии. Ешё однил плюсол является то, что студент ложет сразу закреплять полученные знания на практикен.

Очень ответственно и достаточно откровенно отвечали студенты на вопрос, который волновал практически всех: «Насколько ориентировано, по Вашему мнению, обучение в музыкально-педагогическом вузе на будущее место работы»? В качестве примера приведём ответ студентки 4 курса Елены А.: «Обучение в музыкально-педагогическол вузе недостаточно ориентировано на будущее лесто работы, но везде требуют высшее музыкальное образование при приёме на работу. Только при наличии такого образования возложно дальнейшее устройство в ДМШ».

Ещё один краткий ответ Алексея И.: «На 8 из 10».

Следующий вопрос предполагал получение ответов, раскрывающих представления студентов о той деятельности, которой они себя посвятили: «Опишите вдохновляющие и разочаровывающие стороны Вашей настоящей музыкальной профессиональной деятельности, с чем они связаны»? В качестве примера приведём два ответа, свидетельствующие о принщипиально разных подходах к оценке сту- дентами различных граней своей профессиональной деятельности в зависимости от доминирования в их воззрениях музыкальной или педагогической составляющей:

«Свобода в творчестве, кониертьи, участие в мероприятиях, издательская деятельность. За вреля учёбы в ЛГУ я стала членол Международного союза колпозиторов ХXI века, прошла отбор в школу молодьх колпозиторов в Москве. Постоянно совершенствуюсь и развиваюсь. Отрицательные стороны: в городе Пскове трудно устроиться на рабоmy, низкая зарплата» (Дарья Л.).

«Вдохновляюшие моленты связаньь с талантливылии подросткали, которье приходят на вокал, хотят выступать на конкурсах и участвовать в кониертной деятельности. Разочаровываюшие - плохое техническое оборудование в кабинете вокала, расстроенное пианино. А также чересчур большой объёл ненужной бумажной работь, отнилающей значительную часть врелени, которое могло быть отведено на занятия с подросткали; отсутствие повышения по долюности; маленький оклад; частье вылезднье мероприятия, не связанные с педагогической вокальной деятельностью в нерабочие дни» (Иван Г.).

На вопрос «Каких предметов, не предусмотренных учебным планом, Вам не хватает для своей будущей профессиональной деятельности?» более $63 \%$ опрошенных написали, что учебный план очень разнообразен, количество предметов оптимально. Тем не менее среди интересующих разделов музыковедения и педагогики музыкального образования, которые студенты хотели бы освоить дополнительно, назывались инструментоведе- 
ние, новые музыкальные технологии (методики), музыкальная психология, менеджмент и основы экономики в области культуры, постановка голоса у детей-дошкольников, актёрское мастерство, звукорежиссура.

Самый большой разброс мнений был по вопросу «В каком виде музыкальных знаний, умений и навыков Вы ощущаете заметные пробелы и хотите их заполнить?». В первую очередь назывались инструментальные и вокальные навыки. Также в ответах фиксировалась потребность в формировании менеджерских, дирижёрских, методических, научных, режиссёрских умений. Несколько человек написали, что хотели бы развить у себя «умение офрормлть учебную документацию».

В целом ответы студентов отражали специфику места их работы, заполненную нишу музыкально-образовательной среды, в которой «каждый осуществляет собственный выбор и выстраивает глубоко индивидуальную траекторию своего культурного развития; соответственно личностное становление происходит у каждого в индивидуальном темпе, по индивидуальной траектории» [12, с. 56]. Было приятно видеть огромное желание студентов пройти эту «траекторию развития», их стремление к профрессионально-творческой реализации.

Из ответов студентов выяснилось, что бо́льшая часть опрошенных (32\%) работает в музыкальных школах и школах искусств, преподаёт различные предметы: вокальный, инструментальный и хоровой классы, теоретические дисциплины; 26\% ведут уроки музыки в общеобразовательных школах, лицеях и гимназиях (где дополнительно проводят индивидуальные занятия, чаще всего фортепиано или вокал, академический и эстрадный); 21\% - музыкальные занятия в дошкольных учреждениях (нередко коррекционного типа). Остальные работают на различных должностях в подростковых и молодёжных клубах и центрах, вокальных студиях в ДК, народных и фольклорных коллективах, а также концертмейстерами и хористами.

Многие студенты отмечали в своих ответах, помимо воспитательной и образовательной функции своей профессии, также и важную для них просветительскую составляющую: умение просто, доступно и на высоком качественном уровне рассказать о музыкальном произведении, донести его художественное содержание, придумать интересную развивающую музыкальную программу, возможно, с элементами театральности, сюжетности, фольклора, игры и т. д. Всё это крайне востребовано, и этому студенты хотят учиться.

На вопрос, какие качества студенты хотели бы формировать у своих учеников, большинство опрошенных указывали на способность воспринимать музыку, определяя её как основополагающий индикатор уровня музыкальных занятий. Заметим, что данная способность достаточно специфична, поскольку «...восприятие музыкальных произведений требует от людей более значительных усилий по сравнению с восприятием живописного, архитектурного или литературного произведения. Однако восприятие возможно в силу того, что звуковой материал формируется не на пустом месте, а такие стадии организации материала, которые и позволяют произведению быть воспринятым. Это процесс 
приспособления внемузыкального (выделено мною. - E. кальному тексту, процесс опосредования и трансформации» [13, с. 130]. Тем самым восприятие музыки невозможно без обращения к внемузыкальному, без обращения к контексту. Поэтому контекстуальный подход в профессии должен быть знакомым и привычным методологическим инструментарием будущего учителя музыки.

Очень важно, что практически все опрошенные отмечали потребность в развитии своих исполнительских (инструментальных и вокальных) умений. Мы солидарны с позицией, сформулированной, в частности, Г. М. Цыпиным, что профессиональное становление педагога-музыканта происходит в значительной степени на базе исполнительских дисциплин [14]. В этом смысле очень важно обращение к нотному тексту как основе и источнику формирования творческих, личностных, интерпретационных качеств [15]. Необходимо понимать, что в музыке «одновременно сосуществуют два уровня: внешний - организация мотивов, фраз, блоков музыкального материала, то есть того, что может быть зафиксировано в нотах, и внутренний - организация эмоциональных состояний, настроений, переживаний (через организацию музыкальных интонаций), что не фриксируется нотными знаками, а передаётся только в процессе исполнения музыкального произведения» [16, с. 52]. Понимание единства этих двух уровней - залог развития личностной способности творчески-преобразующе воспринимать музыкальное искусство. Большинство студентов от- метили необходимость корреляции учебных предметов не с абстрактной музыкально-педагогической профрессией, а с конкретной спецификой и проблематикой их места работы.

В целом ответы студентов показали, что в музыкально-педагогической профрессии существует мощная тенденщия, связанная с публичным выражением музыкального творчества детей; просветительской составляющей учебного процесса. Организация разного рода музыкальных спектаклей, лекций-концертов для родителей и сверстников, концертов-встреч, концертов-бесед, музыкальных квестигр, концертов-викторин (где публика сама отгадывает композиторов и их сочинения или даже придумывает им свои названия) становится непременным атрибутом профессиональной деятельности педагога-музыканта. Эта ситуация, помимо исполнительского уровня учителя музыки, значительно актуализирует организационные, режиссёрские, лекторские, менеджерские умения и навыки, которые ещё совсем недавно казались несущественными.

На наш взгляд, в заочном музыкально-педагогическом обучении гораздо легче развить способности педагогов в этом плане, так как, с одной стороны, есть знаниевая база, а с другой - конкретная профессиональная ситуация, знакомая и близкая студенту-заочнику и педагогу в одном лице. В этой контекстной парадигме мы видим мощный стимул мотивированности студента-заочника на максимальную отдачу всего себя учебному процессу и, соответственно, оптимальному сочетанию и взаимодополнению учёбы и профрессиональной деятельности. 


\section{Заключение}

Таким образом, «недостатою» заочного обучения превращается не столько в достоинство, сколько в широкое поле возможностей, зачастую более широкое, чем на обычном дневном отделении. Обучение становится более адресным, ориентированным на конкретного студента и его место работы.

Итак, что же больше присутствует в современном отечественном заочном музыкально-педагогическом образовании - мотивация студентов к обучению или банальная необходимость получить диплом? Можно ли управлять этим балансом, корректировать его в случае необходимости? На наш взгляд, не только можно, но и необходимо. Конечно, создание оптимальной образовательной парадигмы требует соответствующих педагогических условий, технологий, методических и дидактических разработок. Но в этом залог успешности и эдрфективности заочного обучения и профрессионального становления учителя музыки.

\section{БИБЛИОГРАФИЯ}

1. Андреев А. А. Дистанционное обучение: сущность, технология, организация. М.: Изд-во МЭСИ, 2000. $196 \mathrm{c}$.

2. Полат E. C. Дистанционное обучение: организационные и педагогические аспекты // Информатика и образование. 1996. № 3. С. 11-19.

3. Овсянников В. И. Заочная и дистанционная формы обучения: близнецы или антиподы? // Открытое образование. 2002. № 2. С. 64-74.

4. Добрынина Т. Н. Педагогические условия применения интерактивных форм обучения в педагогическом вузе: автореф. дис. ... канд. пед. наук. 13.00.01. Новосибирск, 2003. 21 с.

5. Вяликова Г. С. Педагогическое стимулирование профессиональной компетентности учителя в условиях заочной формы обучения: автореф. дис. ... д-ра пед. наук. 13.00.01. Коломна, 2006. 42 с.

6. Устюжанинова Е. Н. Формирование профессионально важных качеств будущего педагогапсихолога в процессе заочного образования: автореф. дис. ...канд. псих. наук. 19.00.07. Самара, 2006. 24 c.

7. Грищенко Л. Ф. Рейтинговый контроль в организации процесса профессиональной подготовки студентов заочного отделения педагогических вузов: автореф. дис. ... канд. пед. наук. 13.00.08. Сургут, 2002. $21 \mathrm{c.}$

8. Таринова Н. В. Формирование педагогической компетентности студентов-заочников средствами дистанционных форм обучения: дис. ... канд. пед. наук. 13.00.08. Казань, 2018. 201 с.

9. Александрова Н. А. Организация самостоятельной образовательной деятельности студентов-заочников педагогического вуза на основе технологий дистанционного обучения: автореф. дис. ... канд. пед. наук. 13.00.08. Саратов, 2008. 23 с.

10. Гурьева И. И. Модернизация заочного обучения как условие повышения качества профессиональной подготовки студентов в вузе: автореф. дис. ... канд. пед. наук. 13.00.08. Ставрополь, 2007. 22 с.

11. Шамсутдинова И. Г. Педагогические основы высшего заочного образования: учеб. пособие. М.: Изд-во ВЗИИТ, 1991. 162 с.

12. Бузина В. А. Организация мотивирующей социально-культурной среды профессионального образовательного учреждения // Проблемы эффективного использования научного потенци- 
ала общества: сб. ст. по итогам Международной научно-практической конференции. Ч. 3 / отв. ред. А. А. Сукиасян. Стерлитамак: Изд-во АМИ, 2018. С. 55-61.

13. Щирин Д. В. О развитии восприятия музыкального языка произведений в педагогическом процессе на кафедре фортепиано // Кафедра фортепиано: исследования и материалы: сборник статей / под общ. ред. Д. В. Щирина. СПб.: КультИнформПресс, 2018. С. 123-132.

14. Цыпин Г. М. Музыкальное исполнительское искусство: теория и практика. СПб.: Алетейя, 2001. $318 \mathrm{c}$.

15. Корноухов М. Д. Нотный текст - горизонты познания: монография. СПб.: Астерион, 2018. 64 с.

16. Клюев А. С. Сумма музыки. СПб.: Алетейя, 2017. 608 с.

Поступила 04.03.2019; принята к публикации 15.03.2019.

\section{Об ав торе:}

Шумилова Елена Николаевна, концертмейстер кафедры музыкальных дисциплин Государственного автономного образовательного учреждения высшего образования Ленинградской области «Ленинградский государственный университет имени А. С. Пушкина» (Петербургское шоссе, 10, г. Пушкин, Санкт-Петербург, Российская Федерация, 196605), sobaka.mk@mail.ru

Авторол прочитан и одобрен окончательный вариант рукописи.

\section{REFERENCES}

1. Andreev A. A. Distantsionnoe obuchenie: sushchnost', tekhnologiya, organizatsiya [Distance learning: essence, technology, organization]. Moscow: MESI Publ., 2000. 196 p. (in Russian).

2. Polat E. S. Distantsionnoe obuchenie: organizatsionnye i pedagogicheskie aspekty [Distance learning: organizational and pedagogical aspects]. Informatika i obrazovanie, 1996, no. 3, pp. 11-19 (in Russian).

3. Ovsyannikov V. I. Zaochnaya i distantsionnaya formy obucheniya: bliznetsy ili antipody? [Correspondence and distance learning: twins or antipodes?]. Otkrytoe obrazovanie. 2002, no. 2, pp. 64-74 (in Russian).

4. Dobrynina T. N. Pedagogicheskie usloviya primeneniya interaktivnykh form obucheniya $v$ pedagogicheskom vuze [Pedagogical conditions for the use of interactive forms of education in a pedagogical University]. Extended abstract of $\mathrm{PhD}$ dissertation (Pedagogy). 13.00.01. Novosibirsk, 2003. 21 p. (in Russian).

5. Vyalikova G. S. Pedagogicheskoe stimulirovanie professional'noj kompetentnosti uchitelya $v$ usloviyakh zaochnoj formy obucheniya [Pedagogical stimulation of professional competence of teachers in terms of the correspondence form of training]. Extended abstract of Doctoral dissertation (Pedagogy). 13.00.01. Kolomna, 2006. 42 p. (in Russian).

6. Ustyuzhaninova E. N. Formirovanie professional'no vazhnykh kachestv budushchego pedagogapsikhologa v protsesse zaochnogo obrazovaniya [Formation of professionally important qualities of the future teacher-psychologist in the process of correspondence education]. Extended abstract of PhD dissertation (Psychology). 19.00.07. Samara, 2006. 24 p. (in Russian).

7. Grishchenko L. F. Rejtingovyj kontrol'v organizatsii protsessa professional'noj podgotovki studentov zaochnogo otdeleniya pedagogicheskikh vuzov [Rating control in the organization of the process of professional training of students of the correspondence Department of pedagogical 
Universities]. Extended abstract of PhD dissertation (Pedagogy). 13.00.08. Surgut, 2002. 21 p. (in Russian).

8. Tarinova N. V. Formirovanie pedagogicheskoj kompetentnosti studentov-zaochnikov sredstvami distantsionnykh form obucheniya [Formation of pedagogical competence of part-time students by means of distance learning]. PhD dissertation (Pedagogy). 13.00.08. Kazan', 2018. 201 p. (in Russian).

9. Aleksandrova N. A. Organizatsiya samostoyatel'noj obrazovatel'noj deyatel'nosti studentovzaochnikov pedagogicheskogo vuza na osnove tekhnologij distantsionnogo obucheniya [Organization of independent educational activities of part-time students of pedagogical University on the basis of distance learning technologies]. Extended abstract of $\mathrm{PhD}$ dissertation (Pedagogy). 13.00.08. Saratov, 2008. 23 p. (in Russian).

10. Gur'eva I. I. Modernizatsiya zaochnogo obucheniya kak uslovie povysheniya kachestva professional'noj podgotovki studentov $v$ vuze [Modernization of distance learning as a condition of improving the quality of professional training of students at the University]. Extended abstract of PhD dissertation (Pedagogy). 13.00.08. Stavropol', 2007. 22 p. (in Russian).

11. Shamsutdinova I. G. Pedagogicheskie osnovy vysshego zaochnogo obrazovaniya [Pedagogical bases of higher distance education]. Moscow: VZIIT Publ., 1991. 162 p. (in Russian).

12. Buzina V. A. Organizatsiya motiviruyushchej sotsial'no-kul'turnoj sredy professional'nogo obrazovatel'nogo uchrezhdeniya [Organization of motivating socio-cultural environment of professional educational institutions]. Problemy effektivnogo ispol'zovaniya nauchnogo potentsiala obshchestva: sbornik statej po itogam Mezhdunarodnoj nauchno-prakticheskoj konferentsii [Problems of effective use of the scientific potential of society. Collection of articles on the results of the International scientific and practical conference]. Part 3. Responsible editor A. A. Sukiasyan. Sterlitamak: AMI Publ., 2018, pp. 55-61 (in Russian).

13. Sirin D. V. O razvitii vospriyatiya muzykal'nogo yazyka proizvedenij v pedagogicheskom protsesse na kafedre fortepiano [On the development of the perception of the musical language of works in the pedagogical process]. Kafedra fortepiano: issledovaniya i materialy: sbornik statej [Piano Department: studies and materials. Collection of articles:]. Under general editorship of D. V. Sirin. St. Petersburg: Kul'tInformPress Publ., 2018, pp. 123-132 (in Russian, abstract in English).

14. Tsypin G. M. Muzykal'noe ispolnitel'skoe iskusstvo: teoriya i praktika [Musical performing art: theory and practice]. St. Petersburg: Aletejya Publ., 2001. 318 p. (in Russian).

15. Kornoukhov M. D. Notnyj tekst - gorizonty poznaniya [Musical text - horizons of knowledge]. St. Petersburg: Asterion Publ., 2018. 64 p. (in Russian).

16. Klyuev A. S. Summa muzyki [Sum of music]. St. Petersburg: Aletejya Publ., 2017. 608 p. (in Russian).

Submitted 04.03.2019; revised 15.03.2019.

About the author:

Elena N. Shumilova, Concertmaster at the Department of Musical Disciplines, Pushkin Leningrad State University (Peterburgskoe shosse, 10, Pushkin, St. Petersburg, Russia, 196605), sobaka.mk@mail.ru

The author has read and approved the final manuscript. 


\section{МУЗЫКАЛЬНОЕ ИСКУССТВО И ОБРАЗОВАНИЕ - научный журнал, освещающий содержание и результаты научных поисков отечественных и зарубежных учёных в сфере исследования музыкально-педагогических проблем}

\section{ПАМЯТКА ДЛЯ АВТОРОВ}

Статьи для публикации в журнале принимаются по электронной почте на адрес

\section{e-mail: metod-musik@yandex.ru}

К рассмотрению принимаются научные статьи, посвящённые исследованию музыкально-педагогических проблем в сфере общего, дополнительного и профессионального музыкального образования, объёмом до 40000 знаков с пробелами. Текст набирается в программе Word с расширением *.doc; шрифт - Times New Roman; 14 кегль в основном тексте, 12 - в сносках: сноски постраничные, ставятся с использованием функции «сноска» (ctrl+alt+f) в программе Word; межстрочный интервал - полуторный; все поля - 2 см; выравнивание текста по ширине; расстановка переносов автоматическая. Знак сноски - арабская цифра с верхним регистром, место установки знака сноски - перед запятой или точкой, но после вопросительного, восклицательного знаков, многоточия.

Статью завершает автоматически нумерованный библиографический список, оформленный в полном соответствии с действующими государственными стандартами и выстроенный в порядке обращения к источникам в основном тексте, а не в алфавитном порядке. В списке литературы должно быть не менее 15 источников, при этом как минимум 5 источников, опубликованных за последние 10 лет. Ссылки на используемую литературу в тексте оформляются указанием в квадратных скобках порядкового номера источника в библиографическом списке, данного в конце каждой статьи, и - в квадратных скобках (после запятой) - номера страницы. Примеры: [17, с. 25], [3, с. 36]. Примечания к основному тексту делаются постранично: нумерация автоматическая. Нотные примеры, схемы и рисунки создаются в специализированных компьютерных программах.

Абзацы отмечаются отступом в 1,25 см (но не с помощью табуляции или пробелов); интервал между абзацами - обычный, шрифтовые выделения - курсив, в случае необходимости дополнительного выделения - разрядка (автоматическая, объём - 3 пт.), заголовки статей - ПРОПИСНЫЕ буквы (выравнивание по левому краю; после заголовка - инициалы и фамилия автора/авторов курсивом, обычными строчными буквами: выравнивание - слева), подзаголовки - полужирный шрифт, кавычки - типографские («»), внутри цитат - обычные (“”), оригинальные названия художественных произведений - как русских, так и иноязычных - везде даются обычным шрифтом, с прописной буквы и в кавычках («»). Жанровые названия - с прописной буквы, без кавы- 
чек. Порядковые номера симфоний, концертов, сонат даются словами (не цифрой), также с заглавной буквы. Обозначения опусов не отделяются от названия запятой. Пример: Прелюдия h-moll op. 7 № 2, Второй фортепианный концерт ор. 29.

Цитаты даются обычным шрифтом в кавычках, названия звуков - латинскими буквами: $h, \mathrm{G}, \mathrm{a}^{2}$.

Даты обозначаются цифрами: века - римскими, годы и десятилетия - арабскими. Использование русских букв «Х», «У», «Ш», «П» в написании римских цифр, буквы «О» вместо цифры «нуль» не допускается (как и наоборот).

Статья должна содержать аннотацию на русском языке (от 150 до 250 слов) и реферативное изложение основного содержания статьи на английском языке (от 250 до 350 слов), список ключевых слов даётся на русском и английском языках.

Название статьи представляется в редакцию на русском и английском языках.

Текст статьи предполагает деление на подразделы, каждый из которых предваряет подзаголовок, характеризующий его содержательную направленность.

Сведения об авторе на русском и английском языках должны содержать имя, фамилию и отчество (полностью), образование (с указанием учебного заведения и специальности), место работы или учебы (без сокращений), должность, учёное звание, учёную степень, круг научных интересов, e-mail, телефон. Магистранты, аспиранты и докторанты указывают также ФИО, степень, учёное звание, должность научного руководителя/консультанта. Название учебного заведения / место работы на русском и английском языках предоставляется в том варианте, как оно дано в официальных документах / на веб-страницах вузов или научных учреждений. Указывается также его почтовый адрес, включая улицу, дом, индекс населённого пункта.

Редакция оставляет за собой право редактирования, не нарушающего смысла статьи.

Точка зрения авторов публикаций не обязательно совпадает с позицией редакции. Авторы статей несут полную ответственность за точность приводимой информации, цитат, ссылок и списка использованной литературы и источников.

Издание материала, который был ранее помещён в другие печатные или электронные издания, не допускается.

Перепечатка материалов, опубликованных в журнале, невозможна без письменного разрешения редакции.

Подписано в печать 28.03.2019.

Формат 70x100/16. Тираж 1000 экз. 